NIST NCSTAR 1-1C

Federal Building and Fire Safety Investigation of the World Trade Center Disaster

\title{
Maintenance and Modifications to Structural Systems
}

\section{(Appendices A-G)}

David A. Fanella

Arnaldo T. Derecho

S.K. Ghosh 



\section{Appendix A \\ TENANT Construction REVIEW MANUAL - 1971}

THE PORT OF NEW YORK AUTEORITY

NEW YORK, N.Y.

Reproduced with permission of The Port Authority of New York and New Jersey. 


\section{PREFAE}

THE FOLLOWING IS A PRESENTATION OF THE TECHNICAI FUNCTIONS OF THE TENANT CONSTRUCTION REVIEW. IT WAS BEEN PREPARED IN AN EFFORT TO CLARIFY UNDERSTANDING OF THE CONCERNS OF THE PERSONNEL IN THE TENANT CONSTRUCTION REVIEW UNTT. 
PREFACE

IABLE OF CONTENTS

INTRODUCTION

CITIES AND THEIR CODES

GENERAL REQUIRENENTS

FUNCIIONAL REVIEW

ARCHITECTURAL REQUIREMENTS

STRUCTURAL REQUIREMENTS

CIVIL REQUIREYENTS

PROTECTION FROM POTENTIAL FUEL SPILLAGE POINTS

ELECTRICAL REQUIREMENTS

MECHANICAL REQUIREMENTS

PLLMBING REQUIRE'ENTS

FIRE PROTECTION

\section{SECTION}

$Y$

II

III

1

2

3

4

5

6

7

8

9

10

11

APPEIDIX:

FORMS, MEMORANDA 
This pamphlet has been prepared to facilitate the proper and expeditious execution of review work in the Tenant Construction Review Unit. It tries to achleve this by subdividing a job into trades and thus clarifying the posstble scope of a project from functional and technlcal points of view. Detalled checklists based on Building Codes, prepared for each trade, cover the main areas of design and detailing that are expected to receive spectal attention. Finally, design, safety and field coordination criterla additional to Building Code requirements are listed under each trade.

It is hoped that this pamphlet will create a degree of consistancy in review work, and, will establish the basic minimum requirements wich mut be incorporated in the submitted plans and specifications.

Although New York City laws are predominantly used as basis, the check lists may be used for any Eacility in conjunction with the local code. 


\section{CITIES AND THEIR CODES}

\section{NEW YORE CITY}

(1) N.Y.C. Building Code

(a) New Code, Effective December 6, 1968

(b) Old Code, Effective 1938

(c) N.Y.C. Electrical Code

(2) Rules of "The Board of Standards \& Appeals" of N.Y.C.

(3) N.Y. State Labor Law

MENARK (N.J.)

Building Code of City of Newark 1964, Title 7, incl. Appendix N.J. State Plumbing Code

ELIZABETH (N.J.)

Stanciard Building Code of New Jersey including Supplenents 1 and 2 with supplement parts $A, B, C, D \& F$.

Plumbing Code of The City of Elizabeth

JERSEY CITY (N.J.)

Easic Building Code, 1965 Edition as pubiished by Builaing officials Conference of Arerica, Inc., (BOCA)

\section{IETERBORO AIRPORT}

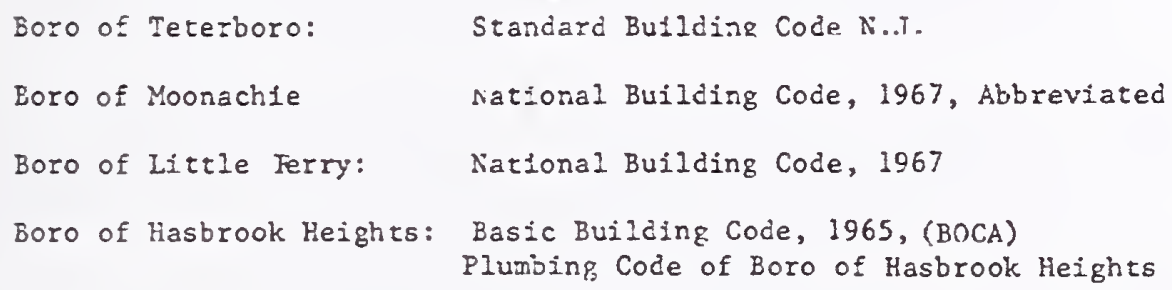

\section{ADDITIONAL CODES}

Where applicable the following shall be referred to:

National Electrical Code; NFPA Standards; N.J. State Labor Law; and additional laws, rules and regulations adopted by the federal, state and local municipal agencies. 


\section{GERERAL REQUIREMENTS}

1. Applicant shall subrit a completed application form, suppliec to him by PONYA, along with his design criteria and plans.

2. For any work done on a roof structure with a valic bond, an addidavit shal1 be obtained by the tenant from the insurer, to the effect that the terms of the bond have not been violated.

3. In order for the P.O.N.Y.A. to obtain the N.Y.C. Fire Department approval of the proposed fire alarm installation, three sets of the following information are reguired to be sent to the P.O.N.Y.A., via the tenant's Alteration Application

a. A plot plan of the bulling showing the exact location of the fire alarm boxes and their xelationship to site conditions, i.e. roads, sidewalk, fences, island, building exits, etc.

b. Details of fire alarm pedestal, foundation, cable and duct installation, etc.

c. Specíncations for fire alam equipement, cable, installation procedures, etc.

d. The above may be submitted in the form of Contract Drawings, sketches and formal specifications, for proper transmittal by povyA to the NYC Fire Department.

4. Before starting the sprinkler work, tenant shall file with PoNXA resident Engineer, sprinkler drawings begring the acceptance stamp (s) of:

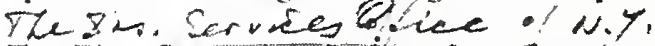
The Fire Insurance Kating-Orgarization of N.Y, $\mathrm{X}_{2}$, The Employe

\section{croup of Imoramce Companies, or, the insurance carrier.}

5. When an application is approved, two (2) sets of conplete plans and specifications shall be submitted to PONYA. For new buildings and major applications one set shall be flled with the Bullaing Department.

6." At the termination of construction a conplete set of as built drawings, in cloth, shall be submitred to PONYA.

7. Each plan shall contain the registration numer, seal, signature and address of Architect or Engineer who prepared the plans. Where the enforcement of. this requirement with the Federal Agency could present difficulties, it is submitted that the following form of the comment should satisfy this requirement: 


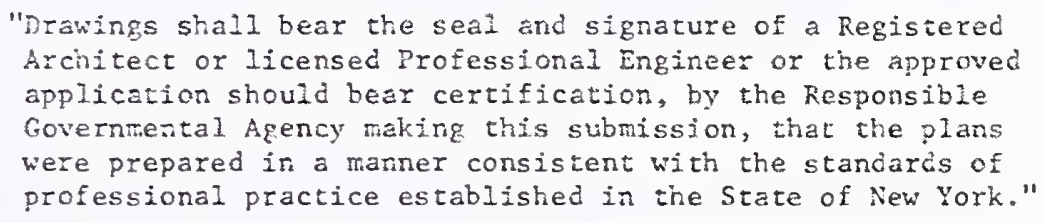

8. Contractors shall obtain POXYA permits for any welding and hot work, in addition to being licensed by the state or the municipality, where applicable.

9. In order to effectuate the policy of the Port of New York Authority, the owner of the premises to be altered, the Contractor shall comply with all provisions of federal, state, municipal, local and departmental laws, ordinances, rules, regulations, and orders which might affect the Contract and the performance thereof and those engaged therein, except where stricter recuirements are contained in the Specifications or indicated on the Drawings, in whici case the Contractor shall comply with the latter requirements. However, the Contractor shall not apply for any variance, license, waiver or permit of any kind in the name of or on betalf of the Port Authority. 


\section{FINCTIONAL REVIEW}

A functional review is a service to an Architect supplementing his feaslbility stucy, reviewing his besign criteria, acqualnting hin with PoNyk interpretations of Buildirg codes and supplemental poryA criteria where necessary. A functional review is a voluntary request on the part of an Architect. There will be no review of plans for extensive code compliance, but of items that day prohibit construction or substantially affect the cesign.

Submitted plans shall be accompanied by an application form and design criteria.

The following is a checklist of items to be reviewed for, but not linitec to: Bullding Coge

1. Occupancy group

2. Construction classification

3. Fire integrity of spaces on the building as it applies to shafis, rating of interior separations, rating of exterior walls and sprink requirements.

4. Egress. Architect shall establish density of occupants and show adequacy of means of egress. Shall coordinate new tenant basic egress layout with existing conditions in existing buildings, in particular $I A B$, where existing conditions conform to $01 d$ Code; stairs are providec from each floor on basis of $75 \%$ of tenant space used as assembly ( 1 person per $10 \mathrm{SF}$ ) and $25 \%$ office ( 1 person per 100 SF); also an "exterior passageway" with minimum predterermed width is layed out on 3 ra $5100 r$, to which egress can be made.

5. Unusual structural conditions, including foundations shall be referred to the structural reviewer.

6. Special mechanical problens, e.g., covered driveways or other deviations from code provisions, shall be referred to the mechanical reviewer.

7. Existing structures are to be reviewed for existing code violations and listed.

\section{PONYA Criteria}

1. Sprinklers in conveyor or baggage handling spaces.

2. Adaptation of code and NFPA standards to loading bricges, hangar buildings and terminal buildings 
3. Protection of buliding areas exposed to tuel splilage and drainage.

4. PA requirements for carpets, furniture, etc.

\section{Coordination with Airport Vtilities}

1. Electrical: Anticipated new power requirements shail be referred to the electrical reviewer.

2. Water supply: Coordination of ary denand for chilied water, high temperature water, domestic water and high pressure sprinkler supply water with PA facilities, and the fire protection loop, shall be referred to the Civil, Mechanical, and Plumbing reviewers.

3. Any work affecting the fuel lines shall be referred to the hydraulic engineer. 


\section{STRUCTURAL}

Notes:

1. Where structural review is required, structural calculations shall be submitzed.

2. The Structural Reviewer is responsible for the structural integrity of all valls and partitions.

3. Upon completion of the solls, and foundarion review, the structural reviever shall take all soils and foundation docunerts to the Engineer of Soils for his review and coments.

4. Upon completion of the superstructure review, the structural reviewer shall take all superstructure documents to the Chief Structural Engineer for his review and coments.

5. Building frames shall be checked for stability and inhibition of sice sway and the effect of same on the slenderness ratio of the columns.

6. For Faterials, Operations and Equipwent subject to controlled Inspection see pages 5.5 to 5.8 inclusive. 
The following check list is based on the new New York Caty Buiding Code, but may be used for any facility in conjunction with the local code

Materials, Assemblies, Forms \& Nethoc's of Construction

Genral Recuirements

Acceptance Requirements

Inspection Requirements

Plans Reçuired

Structural Plans

\section{LOADS}

Dead Lnacs

Floor Live Loads.

Live Loads For Sidewalks, Driveways \& Railings

Roof Loads

Koving Loads

Partial Loading Conditions

Floor Live Load Reduction

Contributory Floor Areas

Wind Loads

Thermal Forces

Shrinkage

Distribution of Loads

STRUCTURAL NORK

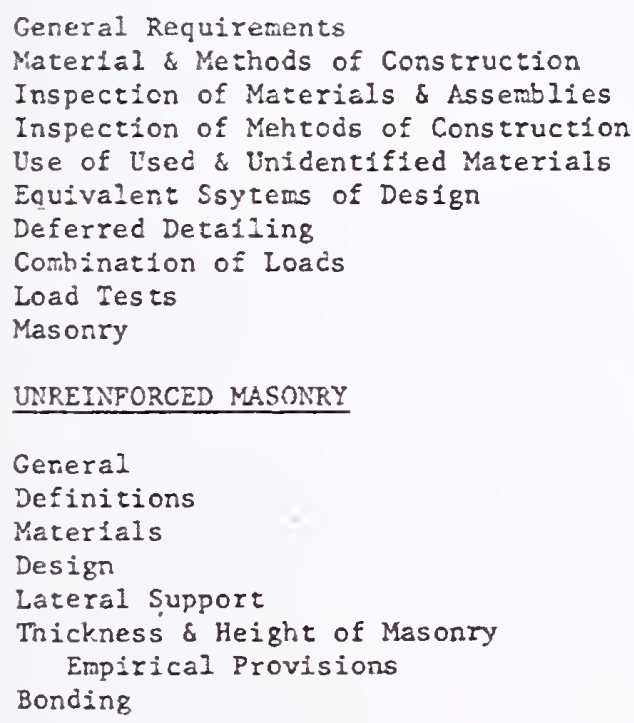

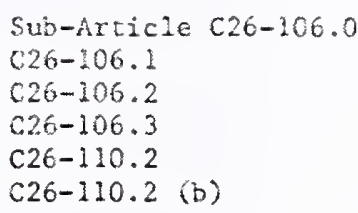

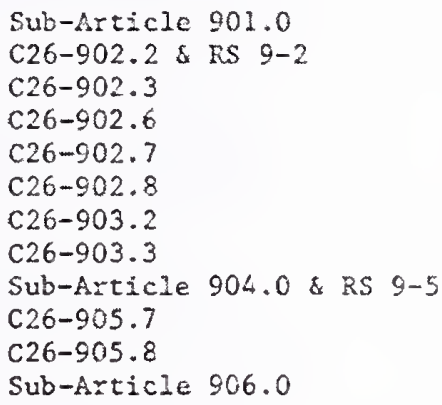

$626-1000.6$ c26-1000.7

Table 10-1

Table 10-2

c $26-1000.9$

C26-1000.10

C26-1000.1

C26-1001. 4

C26-1002.4

Sub-Arricle 1003.0

RS 10-1

$\begin{array}{cc}\text { Section } & 1 \\ " 1 & 2 \\ " & 3 \\ " & 4 \\ & 5 \\ \text { " } & 6 \\ \text { Section } & 7\end{array}$


Growted \& Filled Cell Nasonry

Anchorage

Viscellaneous Requirements

Veneer

Miscellaneous Structures \& Systems

Section 8

" 9

$" 10$

312

Section 12

REINTORCED MSORRY

RS 10-2

Concrete

Concrete Mixes

Short Span Concrete Floor and Roof

Construction Supported on Steel Beans

Sub-Article 1004.0

c26-1004.3

$626-1004.8$

REINEORCED CONCRETE - ACI 318-1963, Builaing Code

Requirement, mocified as specified in

RS $10-3$

STRLCTURAL STEEL - AISC 1969 Specifications for the

Design, Fabrication and Erection of Structural

Steel for Building, modified as specifjed in

RS 10-5

LIGHT GAGE COLD FORMED STEEL - AISI 1968 Specification

for the Design of Lignt Gage Cold Formed Stee]

modified as specified in

RS $10-6$

ONEX WEB STEEL JOISTS - See RS 10-7 for governing specifications and modifications

WoOD - See Sub-Article 1004.0 Table RS 10-8 and RS 10-9

ALUMINUM - See Sub-Article 1007.0 Table RS 10-10 and RS 10-11

GiASS - See Sub-Article 1011.0

SOIL \& FOUNDATIONS

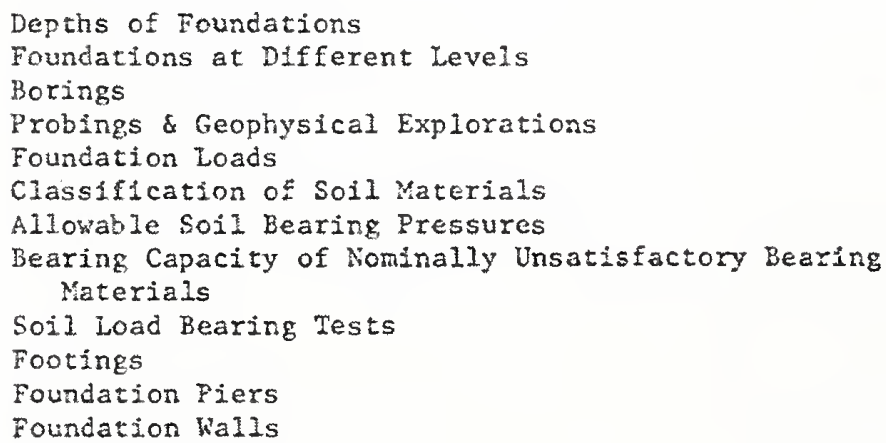

C $26-1100.7$

C26-1100.8

C26-1101.2

C26-1101.5

Sub-Article 1102.0

c26-1103.1

c26-1103.4

C26-1103.5

Sub-Article 1104.0

C26-110s.2

c26-1105.3

c26-1:05.4 


\section{PILE FOUNDAIONS}

Administrative Requirements

Minimum Pile Penetrations

Mininum Sacing of Piles

Capoing \& Bracing of Piles

General Requirements for Installation of Pizes

Allowable Axial Loads on Piles

Allowable Lateral Load

\section{PIJE DRTVING OPERATIONS}

Equipment

Procecures

\section{PILE TYPES}

Tinber Piles

Precast Concrete Piles

Cast-In-Ilace Concrete piles

Compacted Concrete Piles

Steel "H" Sections

Concrete Filled Pipe Piles

Caisson Piles

Composire Piles

Uncerpinning

Stability

\section{INSPECIION}

Boring Operations

Piling

Subgrade for Footings, Foundation Piers \& Walls

Support of Adjacent Properties or Building
C26-1:06.1

c26-1106. 3

C26-1106.5

C26-1106.7

C26-1106.9

C26-1107.1

$\mathrm{c} 26-1107.2$

C26-1108.1

C26-1108.2

C26-1109.2

$\mathrm{C} 26-1109.3$

C26-1109.4

C26-1109.5

C26-1109.6

C26-1109.7

C26-1109.8

C26-1109.9

Sub-Article 1110.0

Sub-Article 1111.0

C26-1112.2

C26-1112.3

C $26-1112.5$

C26-1112.6 


\section{MATERIALS, OPERATIONS AND EOUIPMENT \\ SUBJECT TO CONTROLLED INSPECTION \\ BY BUILDING CODE}

(SEE $\quad 26-106.3$ and $(26-107.3)$

\section{CONCRETE}

1. The inspection of materials for all structural elements proportioned on the basis of calculated stresses 70 percent or greater, of basic allowable values, Table 10-1, Article 10.

2. The making of preliminary tests of concrete, c26-1004.3 (a) (3).

3. Quality control and inspection at the batch plant c26-1004.3 (a) (5) except as provided in C26-1004.3 (b) (6).

4. Actual preparation of cyinders for strength tests, 026-1004.5 (a) (1).

5. The checking of all samples recovered for the purpose of strength tests for slump, air content, unit weight, and temperature in accordance with RS $10-3,(26-1004.5$ (a) (2).

6. The teasurement of fors for size and dimensions of members, c26-1004.5 (a) (3).

7. The checkimg of sizes and position of reinforcement, C26-1004.5 (a) (3).

8. The inspection of placement of concrete and the recording of and compliance with Building Code provisions atteated to/of
(a) Temperatures
(b) Protections against excessive temperatures
(c) Curing
(d) Erection and connection of precast members
(e) Amount of water added in field
(f) Tensioning of all prestressed elerients, C26-1004.5 (a) (3)
(g) Preplaced aggregate C26-1104.11 (c)

9. Inspection for the proper use of admixtures. Batch plant inspection required for all admixtures, other than airmentraining and water-reducing agents, C.26-1004.6.

II. SPEEL

1. Inspection of welding operations where stresses in welds are $50 \%$ or more of basic allowable values, Table 10-2.

2. Check of welders" licenses or qualifications in accordance with c26-100:.3 (2), c26-1005.3 (4). 
3. Inspection of the tensioning of high strength bolts where stresses in bolts are $50 \%$ or more of basic allowable values, Table 10-2.

4. Inspection of the connection of fittings to wire cables, except where proof-ioaing to not less than $55 \%$ uitimate capacity, Tahle $10-2$.

?. R.LUMINTN

1. Inspection of weicing operations where stresses in welds are 50\% or roze of basic ailowable values, rable 10-2.

2. Check of welders' Iicenses or qualifications in accordance with C26-1007.3 (b) (2), C26-1007.3 (b) (4).

TV. inOD

1. Inspection of the fabrication of glued-laminated assemblies and of plywood componencs, Table 10-2.

2. Check of sizes of members, of fit, and of gluing operations for glued-ianinated assemblies, c26-i006.4.

V. REIAFORCED MASONRY (Table 10-2, Article 10 of Building Code)

1. Inspection of fabrication of prefabricated units.

2. Inspection of placement and bedding of units.

3. Check of sizes of members, inclucing thickness of walls and wythes.

4. Check of sizes of colums,

5. Check of sizes and position of reirforzerent in place.

6. Inspection of means of protection against freezing.

7. Inspection of provisions for curing.

VI. UAREINFORCED MASONRY (based on structural analysis, RS 10-1, Section 4, Table 10-2, Article 10 of Building Code).

1. Inspection of placement and bedding of units.

2. Check of sizes of members including thickness of wall and wythes.

3. Check sizes of columns

4. Inspection of provistons for curing.

5. Inspection of means of protection against freezing.

VII. FOUNDATIONS

1. Inspection of boring operations, c26-1112.2.

2. Inspection of piling including load teste, C26-112.3 
3. Inspection of slbgrace for footings, Founcation piers, anc Eundation walis (notification to PONYA Resident Engineer at least 2 days prior to installation required unless department inspection is waived uncer $(26-120.5),(26-1112.5$.

4. Inspection of uncerpining operations, construction and excavation of temporary or permanent coffercams, cajssons, braced excavated surfaces and other constructions or excavations affecting support of adjacent properties or builìings. (Plans reçuired), C26-1112.6.

5. Evaluation of laboratory ficid tests for the verification of the magritude of stabilized overburden pressure, C26-1103.4 (b), (c).

6. Supervision of the placing of controlled fills, C26-1103.5 (a) (1) (Note that where foundation is to rest on, or be underlain by, nominaliy unsatisfactory bearing materials, a report based on soli tests, foundation analysis (including analysis of undisturbed samples), by architect of engineer is required, $\mathrm{c} 26-1103.5, \mathrm{C} 26-1103.5$ (b) (2).)

\section{VIII.MATERIALS, ASSEMBLIES FORMS AND METHODS OF CONSTRUCTION}

CODE TEST METHOD Whenever thie Eulliting Code prescribes a method of testing such tests shall be made under the supervision of an architect or an engineer; or by a testing service or iaboratory acceptabie to the PONYA Resident Engineer C26-106.2 (a) (1).

\section{MSPECTEONS DURING PROGESS OF WORK}

The comissioner may accept signed statements by architects and engineers and supporting inspection and test reports without verifying inspection or test by department inspectors, c26-120.5.

\section{FINAL INSPECTION}

The architect, engineer, or other person who supervised or superintenced the work is required to be present at final inspection by department, c26-120.6. 


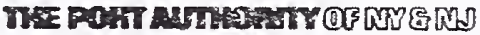

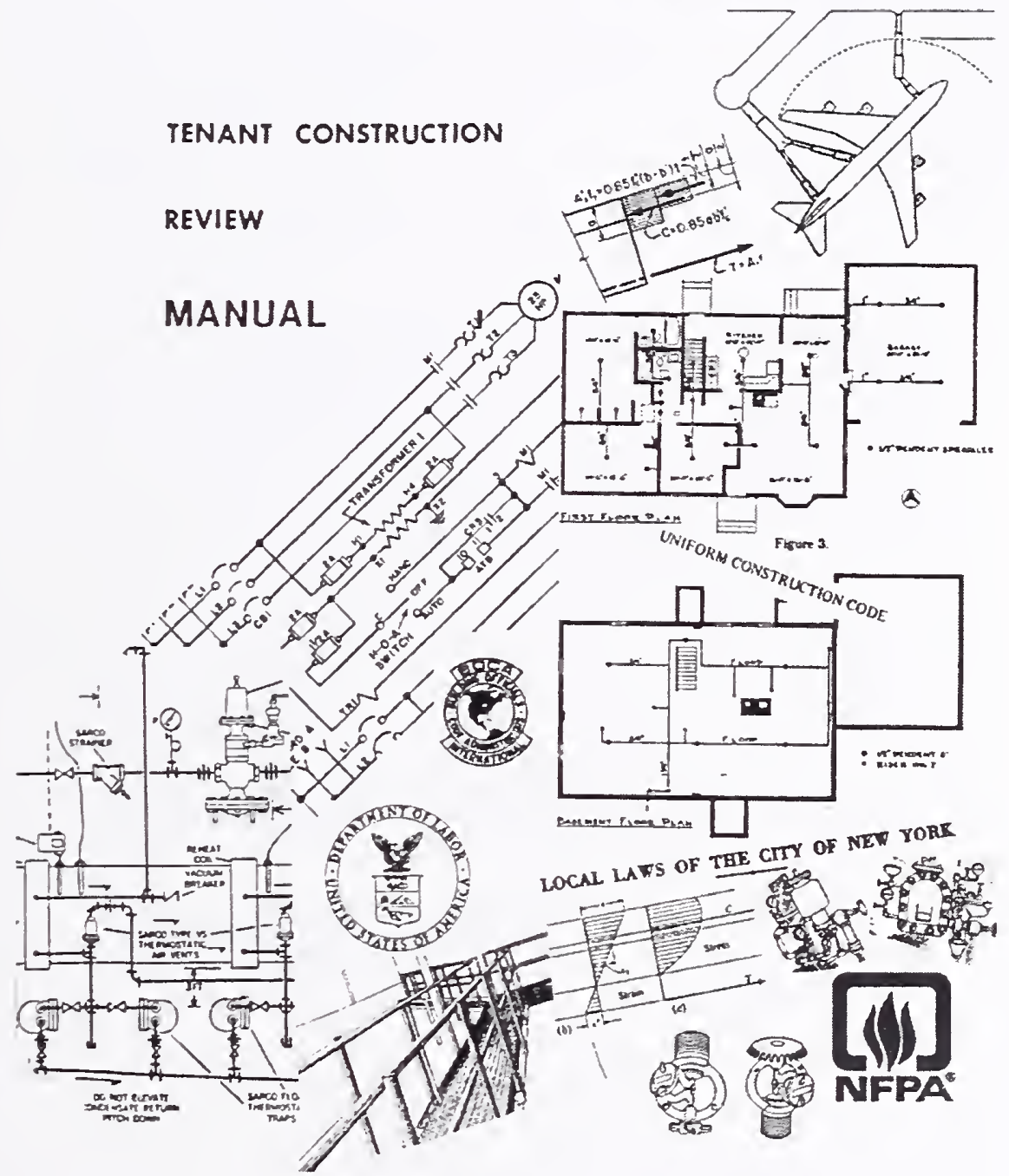

Reproduced with permission of The Port Authority of New York and New Jersey. 


\section{PREFACE}

THE FOLLOWING IS A PRESENTATION OF TECHNICAL, CRITERIA USED IN THE REVIEW OF TENANT CONSTRUCTION. IT HAS BEEN PREPARED IN AN EFFORT TO DEFINE THE CONCERNS OF THE TENANT CONSTRUCTION REVIEW UNIT 


\begin{tabular}{|c|c|}
\hline & SECTION \\
\hline PREFACE & I \\
\hline TABLE OF CONTENTS & II \\
\hline INIRODUCTION & III \\
\hline CODES, RULES \& REGULATIONS & 1 \\
\hline GENERAL REQUIREMENTS & 2 \\
\hline FUNCTIONAL REVIEW & 3 \\
\hline ARCHITECTURAL REQU IREMENTS & 4 \\
\hline STRUCTURAL PEQUIREMENTS & 5 \\
\hline CIVIL REQUIREMEITS & 6 \\
\hline PROTECTION FROM POTENTIAL FUEL SPILLAGE POINTS & 7 \\
\hline ELECTRICAL REQUIREMENTS & 8 \\
\hline MECHANICAL REQUIREMENTS & 9 \\
\hline PLUMBING REOUUIREMENTS & 10 \\
\hline FIRE PROTECTION & 11 \\
\hline MATERIALS, OPERATIONS AND EQUIPMENT SUBJECT & \\
\hline TO INSPECTION REQUIRED BY BUILDING CODE & 12 \\
\hline APPENDIX: & \\
\hline
\end{tabular}


This parphlet has been prepared to facilitate the proper and expeditious execution of review work in the Tenant Construction Review Unit. It tries to achleve this subdividing a job into separate disciplines and thus clarifying the possible scope of a project from functlonal and technical polnts of view. Detalled checklists based on Bullding Codes, prepared for each discipline, cover the main areas of design and detalling that are expected to receive special attention. Finally, design, safety and field coordination criteris additional to Bullding Code requirements are listed under each discipline.

It is hoped that this pamphlet w111 create a degree of consistancy in review work, and, will establish the basic minimum requirements which must be incorporated in the submitted plans and specifications. 
CODES, RULES AND REGULATIONS

NEW YORK

(1) N.Y.C. Bullding Code

(a) New Code, Effective December 6, 1968

(b) Old Code, Effective 1938

(c) N.Y.C. Electrical Code

(2) Rules of "The Board of Standards and Appeals" of N.Y.C.

(3) N.Y. State Labor Law

N.Y. State Energy Conservation Construction Code

NEW JERSEY

Since January 1977 all comunities in the State are required to conduct their construction activitles in accordance with the STATE UNIFORY CONSTRUCTION CODE which was made part of the New Jersey Aduinistration Code (NJAC) as Chapter 23 of Iitle 5 . Under the code the following subcodes have been adopted:

1. Bullding subcode - The BOCA Basic Bullding Code/1978

2. Plumbing Subcode - The National Standard Plumbing Code/1978

3. Electrical Subcode - The Nat1onal Electrical Code/1978

4. Fire Protection Subcode - Portions of BOCA NEC applicable to fire protection

5. Energy Subcode - (a) BOCA Basic Energy Conservation Code

(b) Illuminating Engineers Soclety Standard EMS-1: Lighting and Power Budget Determination Procedure

All above Subcodes were adopted with a provision that they shall "Include all subsequent revisions and amendments thereto". Also certain specific sections of the subcodes have been altered or deleted.

Also in New Jersey the following codes are in effect:

1. Barrier-Free Des1gn - promulgated by the Dept. of Treasury Division of Bulldings \& Construction

2. NJAC - Title 12 - The Labor Law

3. NJAC - Title 7 - Environmental Protection Laws 
STANDARDS APPLICABLE IN ALL P.A. FACILITIES

1. Occupational Safety \& Health Act (OSHA)

2. Feđ̌era1 Standard for Making Bu1ddings Usable by the Physically Handicapped (P.L. $-90-480$ ) (ANSI A117.1)

3. Federal Floodproofing Regulations

4. F.A.A. - Standards (at Airports) 


\section{GENERAL REQUIREMENTS}

1. Each application submitted must be accompanied by properly completed and executed application form, supplied to the tenant by the Port Authority.

2. For proper technical review besides the drawings, signed and sealed by the Reglstered Architect or the Professional Engineer, design criterla, specifications and calculations shall be subtitted.

3. In order for the Port Authority to obtain the N.Y.C. Fire Department approval of the proposed fire alarm Installation, three sets of the following information are required to be sent to the P.A., via the tenant's Alteration Application.

a. A plot plan of the building showing the exact location of the fire alarm boxes and their relationship to site conditions, 1.e., roads, sidewalk, fences, island, bullding exits, etc.

b. Detalls of fire alarm pedestal, foundation, cable, installation procedures, etc.

c. Speciflcations for fire alarw equipment, cable, installation procedures, etc.

d. The above may be submitted in the form of Contract Drawings, sketches and formal specifications, for proper transmittal by P.A. to the NYC Fire Department.

4. Before starting work on sprinkler systems, dry chemical, Halon, or other fixed plpe fire extingulshing systems, shop drawings shall be submitted to the P.A. Risk Management Division, and then filed with the P.A. Resident Englneer or Fac1lity Manager.

5. When an application is approved, two (2) sets of complete plans and specifications shall be submitted to P.A.; for new bulldings and major applications, one set will be flled with the Bulldings Department by the P.A.

6. At the termination of construction a complete set of as-bullt drawings, on microfilm, or on cloth, shall be submitted to the P.A. Specifications for microfilm mounted on aperture cards can be obtained from the Business Administration office at the fac1lity. 
7. Contractors shall obtain P.A. permits for any welding and hot work, in addition to being licensed by the state or the municipality, where applicable.

8. In order to effectuate the pollcy of the Port Authorlty of New York and New Jersey, the Tenant shall comply with all provisions of federal, state, municipal, local and departmental laws, ordinances, rules, regulations, and orders which might affect the contract and the performance thereof and those engaged therein, except where stricter requirement $s$ are contained In the specifications or indicated on the drawings, the latter shall be followed. The Tenant or his agents shall not apply for any variance, 11cense, walver or permit of any $k$ ind in the name of or on behalf of the Port Authorlty. 


\section{FUNCTIONAL REVIEW}

A Functional Review is a service to a tenant, when requested by him, supplementing his consultants' feasibility study, reviewing their design criterla, and acquainting thet with specific pre-existing conditions of compliance with a Bullding Code or PANY/NJ criteria that would affect the proposed work. Functional Reviews shall be confined to fundamental concepts, items that may prohibit construction or substantially affect the design.

Submitted plans shall establish the applicable Codes and be accompanied by design criteria.

The scope of the Functional Review shall include, but not necessarily be limited to, the following items.

\section{BUILDING CODE}

1. Occupancy group and construction classification of the altered and adjacent areas.

2. Fire integrity of spaces in the bullding as $1 t$ applies to shafts, rating of interior separations, rating of exterior walls and sprinkler requirements.

3. Egress. Density of occupants and adequacy of egress shall be established. Alternately, tenant's architect/ engineer may list the applicable sections of the Code on which the design is based. New tenant egress scheme shall be coordinated with existing conditions, e.g.,

a) In IAB, where basic egress conforms to old Code, stairs are provided from each floor on basts of $75 \%$ of tenant space used as assembly ( 1 person per 10 S.F.) and $25 \%$ office (I person per 100 S.F.).

b) Also in IAB an "exterfor passageway" with a minimum predetermined width is laid out on 3rd floor, to which egress can be made.

c) On the third ( $3 r d$ ) floor of the Terminal Bullding at LGA a Safe Area exlsts in compliance with Article 8 of the 1968 Code as part of the overall means of egress from the floor. 
4. Unusual structural conditions, Including foundations, shall be referred to the structural reviewer,

5. Special mechanical or electrical problems affecting unusual environmental, energy or power comitments. or other deviations from Code provisions, shall be referred to the mechanical or electrical reviewer.

6. Existing structures shall be revlewed for existing Code violations.

\section{PANY/NJ CRITERIA}

1. Sprinklers in conveyor spaces.

2. Adaptation of Code and NFPA standards to loading bridges, hangars and terminal buildings.

3. Protection of bullaing areas exposed to fuel splllage and dralnage (See Section 7 of this manual).

4. Requirements for carpets, furniture, etc.

\section{COORDINATION WTTH AIRPORT FACILITIES}

1. Electrical: Anticlpated new power requirements shall be referred to the electrical reviewer.

2. Water supply: Coordination of any demand for chilled water, high temperature water, domestic water, high pressure sprinkler supply water, and connections to the fire protection loop, shall be referred to the Civil, Mechanical, and Plumblng Reviewers, and/or the Fire Protection engineer.

3. Any work affecting the fuel lines shall be referred to the appropriate engineer. 


\section{STRUCTURAL}

A. PLANS, NOTES, SCHEDULES

Plans

1. Each plan shall contain the registration, seal, signature and address of the Architect or Engineer who prepared the plans. C26-110.2.

2. Structural plans shall contain the information required by the code. C26-110.2(b).

\section{Notes}

1. Where structural revlew is required, structural calculations shall be subritted.

2. Upon completion of the soils and foundation review, the structural reviewer shall take a11 solls and foundation documents to the Engineer of Solls for his review and comments.

3. Upon completion of the superstructure review, the structural reviewer shall take all superstructure documents to the Chlef Structural Engineer for his review and comments.

4. Bullding frames shall be checked for stability and inhibition of side-sway and the effect of same on the slenderness ratio of the columns.

5. All materials, assemblies, forms or methods of construction and equipment that are subject to controlled inspection shall be listed on drawing. See Section 12 of this Manual.

6. Rules and Regulations 1 isted on $p .5 .4$ shall also be referred to as required.

Schedules

All required schedules for structural and foundation elements are required to be on the plans, 1.e. buttress and pler schedule, grade beams, column schedule, etc. 
B. CHECKLIST

The following is a checklist of the more significant code itens with which the review will be concerned, but not. Iint ted to:

Loads

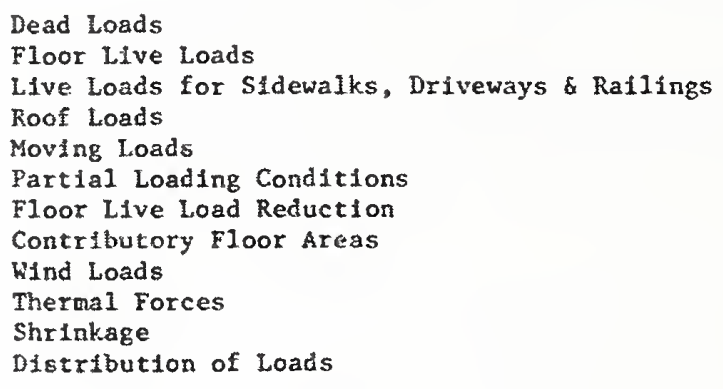

Structura1 Work

General Requirements

Material \& Methods of Construction

Inspection of Materials \& Assemblies

Inspection of Methods of Construction

Use of Used \& Unidentifled Materials

Equivalent Systems of Design

Deferred Detailing

Combination of Loads

Load Tests

Fire Protection Requirements

\section{Solis and Foundation}

Depths of Foundations

Foundations at Different levels

Slabs on Grades Construction

Borings

Probling \& Geophysical Explorations

Foundation Loads

Classification of Solls Materlals

Allowable Soll Bearing Pressures

Bearing Capacity of Nominally Unsatisfactory Bearing Materials

Solls Loading Bearing Tests

Footings

Foundation Plers

Foundation Walls 
Plle Foundations

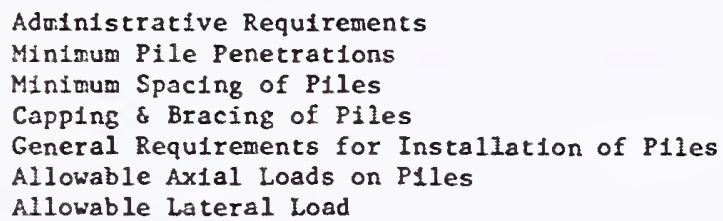

Plle Driving Operations

Equipment

Procedures

Pile Types

Timber Piles

Precast Concrete Piles

Cast-In-Place Concrete Piles

Compacted Concrete Piles

Steel "H" Sections

Concrete Filled Pipe Piles

Calsson Piles

Composite P1les

Underpinning

Stab1lity

\title{
Inspection
}

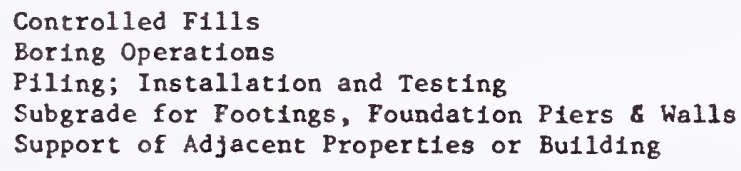

\section{Reports Required}

\author{
Verification - Stabilized overburden \\ Bearing Capacity of Nominally Unsatisfactory \\ Bearing Material \\ Alternate or Similitude Method for Pile Load \\ Verification \\ Substantiation of Higher Allowable P1le Loads
}

\section{ADDITIONAL PORT AUTHORITY CRITERIA}

Bulldings designed and/or constructed by PANY/IIJ that are being altered should be coordinated with the particular facility design group, especially for foundation requirements. 


\section{RULES AND REGULATIONS RELATING TO STRUCTURAL ITEMS}

(Applicable in N.Y.C.)

1. Rules and Regulations Relating to Resistance to Progressive Collapse Under Extreme Local Loads (Bldg. Dept.).

2. Rules and Regulations for the Design of Composite Construction with Metal Decks or LIghtweight Concrete (Bldg. Dept.).

3. Rules Relating to Structural Designs Based on Electronic Computer Computations (Bldg. Dept.).

4. Rules and Regulations Relating to the Design and Installation of Curtain Wall Systems (BIdg. Dept.).

5. Rules for Application and Protection of Sprayed-OnFireproofing (BSA Cal. $118-68-G R$ ).

6. Rules and Regulations for Mascnry Parapet Walls. (Bldg. Dept.)

7. Rules for Arc and Gas Welding and Oxygen Cutting of Steel Covering the Specifications for Design, Fabrication and Inspection of Arc and Gas Welded Steel Structures and the Qualffication of Welders and Supervisors (BSA Cal. 1-38-SR).

8. Rules for Governing the Marking of Transparent Glass Doors and Fixed Adjacent Glass Sidelights (BSA Cal. \#01-68-SR).

9. Rules for the Manufacture, Testing and Use of Concrete Masonry Units (BSA Cal. $(639-40-S R$ ). 
MATERIALS, OPERATIONS AND EQUIPMENT

SUBJECT TO INSPECTION REQUIRED BY BUILDING CODE

The purpose of this section is to list some of the materials, operations and equipment which normally require the services of a licensed professional engineer in order to assure code compliance in confunction with norwal Inspection procedures contained in Subarticles 106.0 and 107.0 of the N.Y.C. Bullding Code and Subchapter 2, sec. 5:22-2.6 of the New Jersey Untform Construction Code.

\section{MATERIAIS}

\section{Concrete}

Katerlals for all structural elements proportioned on the bas1s of calculated stresses 70 percent or greater, of the basic cllowable values. Inspection includes making of prelininary tests for concrete and quality control and inspection at the batch plant.

Notes:

a. For general provisions relating to inspection see bullding code section and reference standards.

b. All Etructural materials subject to controlled inspection shall be tested and/or inspected at the place of manufacture and evidence of compliance shall be provided.

c. M111, manufacturer's, suppliers' Inspection and test reports w1ll be accepted as evidence of compliance with the provisions of the code for all structural materials and assemblies not subject to controlled inspection.

\section{OPERATIONS AND METHODS OF CONSTRUCTION}

\section{Steel}

1. Helding operations and the tensioning of high strength bolts in connections where the calculated stresses in the welds or bolts are 50 percent or more of basic allowable values.

2. Inspection of the connection of fittings to wire cables, except where proof-loading to not less than 55 percent of ultimate capacity. 


\section{Concrete}

1. Actual preparation of cylinders for strength tests.

2. The checking of all samples recovered for the purpose of strength tests for siump, admixtures, air content, unit weight, and temperature.

3. The checking of sizes and position of reluforcement.

4. The Inspection of placement of concrete and watrenance of records and veriffcation for:
a. Temperatures
b. Protections against excessive temperatures
c. Curing
d. Erection and connection of precast members
e. Amount of water added in the fleld
f. Tenstoning of all prestressed elements
g. Preplaced aggregate

5. Inspection for proper use of admixtures. Batch plant Inspection required for all admixtures, other than air-entralning and water-reducling agents.

Aluminum

Inspection of welding operations where stresses in welds are $50 \%$ or more of basic allowable values.

Wood

Inspection of the fahrication of glued-laminated assemblies and of plywood components.

\section{Relnforced Masonry}

1. Fabrication of prefabricated units.

2. Placement and bedding of untes; sizes of members, Including thickness of walls and wythes; sizes of columns; the size and postition of reinforcement, in place, and provistons for curing and protection agalnat freezing for all relnforced masonry construction. 


\section{Unreinforced Masonry}

Placement and bedding of units and sizes of members including thickness of walls and wythes; sizes of colunns; and provisions for curing and protection against freezing for all masonry construction proportioned on the basis of structural analysis as described in the reference standard.

\section{Solls and Foundations}

1. Controlled Fills

2. Boring Operations

3. Piling; Installation and Testing

4. Subgrade for Footings, Foundation Plers and Walls

5. Support of Adjacent Properties or Building

\section{F1restopping}

Installation of all firestopping where required.

\section{Fireproofing}

All fireproofing other than the concrete encasement.

Notes:

a. For general provisions relating to inspection see appropriate bullding code sections and reference standard.

b. All construction operations designated for controlled inspection shall be inspected by the architect or engineer designated for controlled inspection during the performance of such operation.

c. Certification by the fabricator or erector, as applicable, will be accepted as evidence of compliance with the provisions of this code for all construction operations not subject to controlled inspection.

\section{EQUIPRENT}

Required ventilating systems including functioning of any required smoke detection and fire protection devices.

Refrigerating Systems

Bollers

Fuel Burning Equipment

Chimney Smoke Test (where applicable)

* Fire Standpipe System

* Fire Pumps

* Fire Alarm \& Signaling System Electrical Test 
* Sprinkler System

* Voluntary Ventilating Systen with required Snoke Detection and Fire Protection Devices

* Sol1 Percolation Test

* Plumbing and Gas Piping System

(* The test of this item shall be witnessed by a facility representatıve).

Notes:

a. For general provistons relating to inspection see appropriate building code sections and reference standard.

b. AII equipment testing designated for controlled Inspection shal1 be inspected by the architect or engineer designated for controlled inspection during the performance of such operation.

c. Certification by the manufacturer of equipment, as applicable, will be accepted as evidence of compliance with the provisions of this code for all equipment not subject to controlied Inspection.

\section{CHECKLIST OF ITEMS SUBJECT TO CONTROLLED INSPECITON}

Only major construction items are listed here and therefore the controlled inspection shall not be limited to these items only.

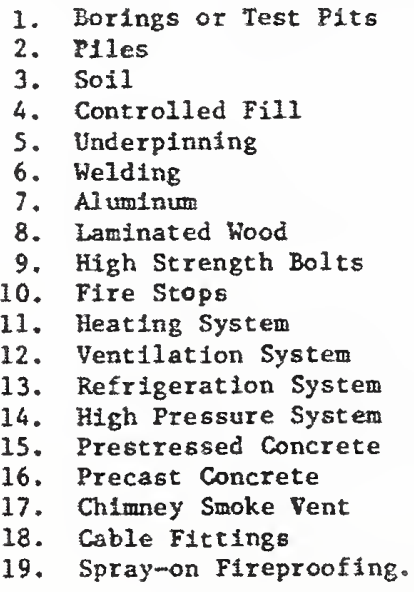




\section{Appendix C \\ Tenant Construction ReView Manual - 1990}

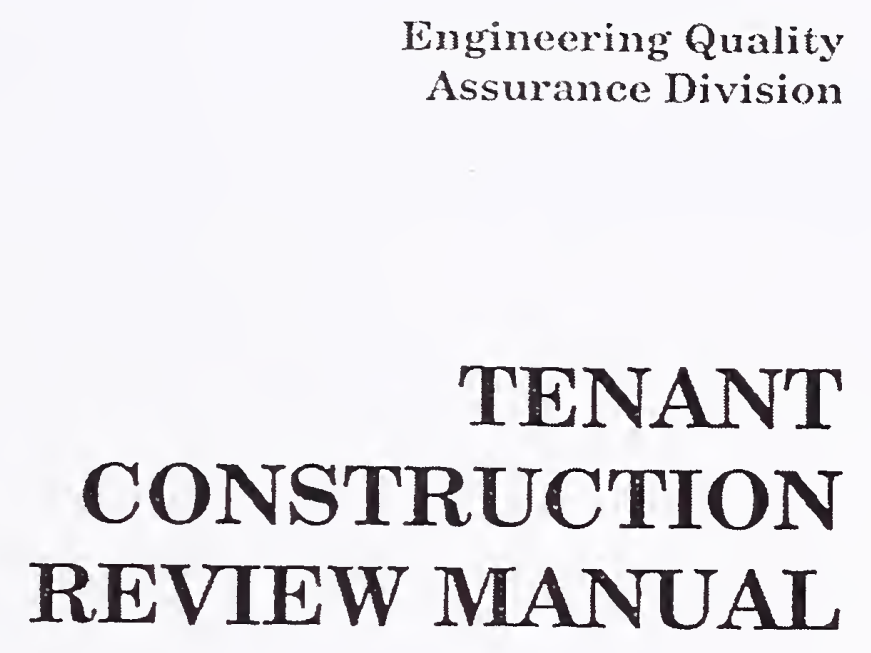

March 1984

Revised March 1990

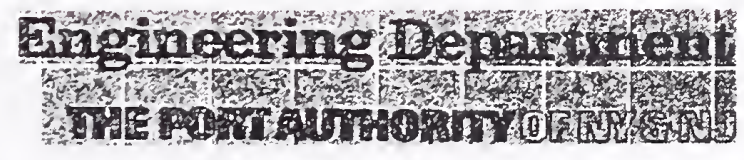

Reproduced with permission of The Port Authority of New York and New Jersey. 
TAELB OF CONTENTS

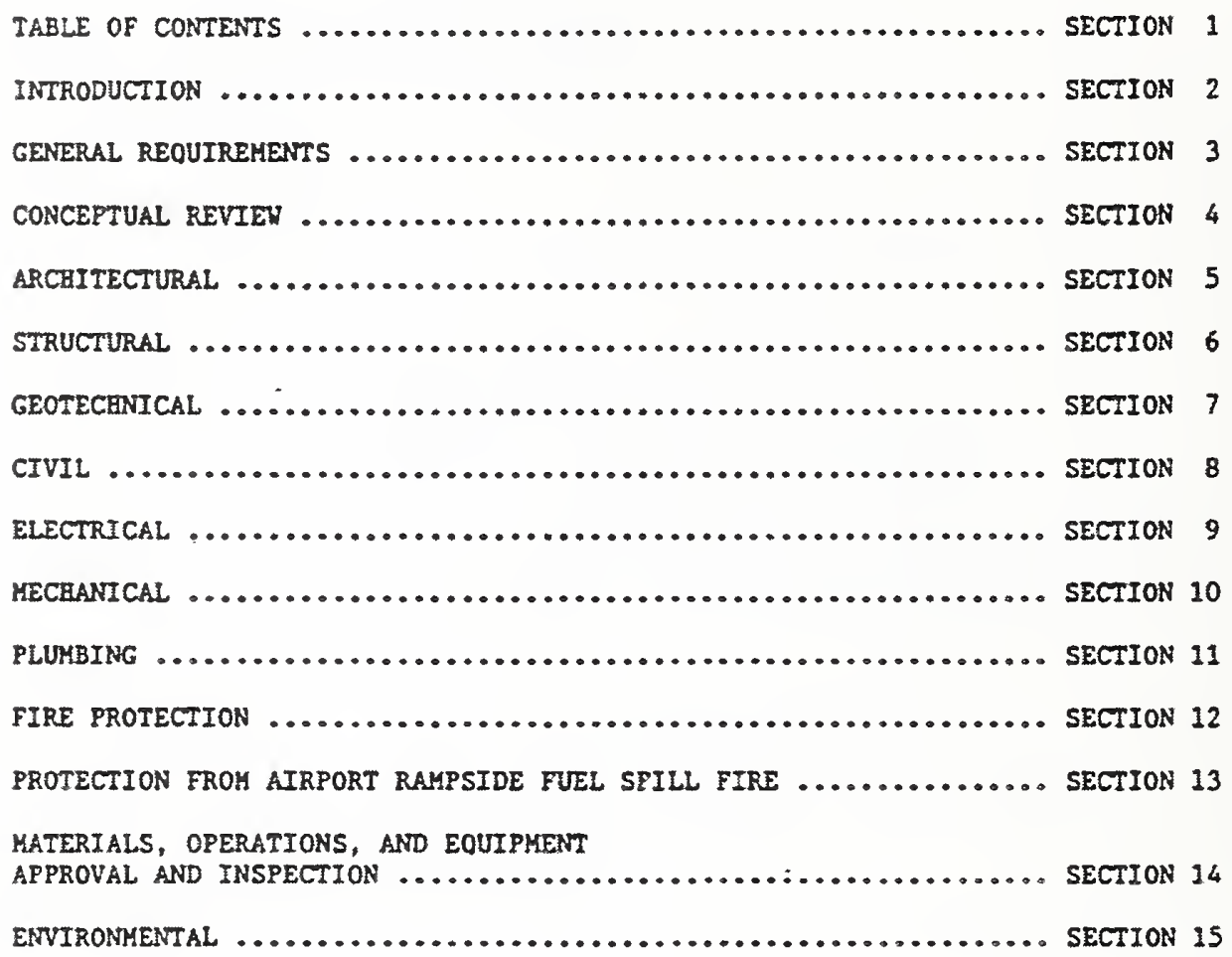

ATTACHHENTS 


\section{LIST OF ATIACEMENTS}

A1 Specifications Goveming The Flamability of Carpets.

A2 Specifications Governing The Flamability of Drapery And Curtain Materials.

A3 Speciflcations Governing The Flamability of Upholstery Material And Plastic Purniture.

A4 Speciflcations Governing The Flamability of Plastic Laminate And vood Veneer Fumlture.

S1 Cement Plaster Cellings.

S2 Lightveight Ceilings in Nev Jersey.

S3 Lightrelght Cellings in The Vorld Irade Center.

C1 Taxivay Paving.

C2 Protection of Underground Pipes.

H1 Port Authority Bus Terainal South Ving - BVAC Criteria.

M2 Port Authority Bus Terminal North Wing - BVAC Criteria.

M3 Port Authorfty Bus Terminal - Electrical Criteria.

F1 Nev Tork City Municipal Fire Alarm.

RFS-1 Alrport Rampside Clearances. 
This Manual is published to present the technical criteria to be considered by Tenants at Port Authorlty facilities In, connection with construction work undertaken by a Tenant, which 15 in addition to other requirements under the agreement betveen the Port Authorlty and the Tenant. This Manual also covers the Port Authority Engineering Departwent scope-of-review of the design documents (plans, specifications, calculations and other documentation) subalted by Tenants in connection with proposed construction or alterations. It shall not be deemed to imply that there will not be additional revieus by other Port Authority Departaents.

Revievs will not address the proposed aesthetic or functional aspects of the design.

Construction documents for Tenant alterations will be revieved by the Engineering Department for compliance with applicable Codes and Port Authority Engineering Standards. In the absence of a speciflc code provision, this Manual sets forth the applicable standards to be folloved by Tenants except as may othervise be required of the Tenant. All design documents shall reflect the existing construction as vell as the proposed work in order to deterwine compatibility vith existing conditions at tacilities.

In this regard a list of all documents and guidelines which the Facility has provided to the Tenant, and which affects the design, should become an integral part of the Tenant's contract document submission. If the subsequent reviev process will be aided by the inclusion of the construction documents itemized on this 1ist, such documents should also be included in the submission.

The Tenant Construction Reviev Undt of the Engineering Department w1I reviev the Tenant Construction or Alteration Application subait ted by the Tenant in accordance 1 th the criteria included in this Manual. The responsibility for engineering design shall rewain with the Tenant's Engineer or Architect preparing the design. The Tenant Construction Reviev Unit wil not impose solutions to engineering problems but vill comment on the design presented. 
1. All proposed construction shall be submitted for reviev, in completed form, accompanied by a "Tenant Construction or Alteration Application," For PA531, which shall be provided to the Tenant by the approprlate Port Authorlty IIne departaent.

The Iine department shall speclfy to the Engineering Department, the technical disciplines to be revieved for the submitted projects.

2. The destgn documents, such as dravings, reports, computations and spectflcations, required in connection with the proposed construction, shall be attached to and ford a part of the Tenant Construction or Alteration Application, and shall reflect the existing construction as vell as the proposed vork, and be sealed and signed by the architect or engineer of record licensed to practice in the State in vhich the proposed construction is to be perforwed. The architect/engineer indicated on the Application shall be considered the $A / E$ of record.

Where the $A / E$ of record subalts documents prepared by other consultants, he is responsible for assuring that the documents from all the consultants are properly coordinated.

Where other consultants have been acknovledged by the A/E of record, efther in the Alteration Application or on the dravings, said consultants ay seal and sign the docusents they have prepared.

Where the Tenant retains two or more independently functioning consultants, they each become an $A / E$ of record for the scope of their vork, for which each vill be required to submit a separate Alteration Application, and each such consultant shall seal and sign the docurents he subalis.

Responsibility for design or code compliance shall not be delegated to contractors.

3. Voluntarily installed systems, such as sprinklers, alarm, etc., shall comply vith the provistons of the Building Codes for such systems. 
4. Pire protection plans, as described in the Nev York City Building Code Section 27-228,1 (C26-124.1) et seq., shall be filed for reviev along with other design documents for construction projects in all the Port Authority facilities. After the approval of the project for construction, and before a certificate of occupancy is 1ssued, one (1) copy of these plans shall be subait ted to the manager of the facility where the project is located and two (2) copies shall be filed with the Quality Assurance Division of the Engineering Department.

5. In accordance vith the policy of the Port Authority of New York and New Jersey, the Tenant shall comply with the provisions of all federal, state, municipal, local and departmental lavs, ordinances, rules, regulations and orders that may affect the contract and all individuals involved therein. Where stricter requirements apply, 1.e., those contained in the speclfications or drawings, they shall be followed. The Tenant or his agents shall not apply for any variance, license, vaiver or permit in the name of or on behalf of the Port Authority. 
D. Special structural conditions, including foundations.

E. Special or unusual mechanical or electrical problems affecting environmental, energy or power requirements.

F. Deviations from Code provisions.

G. Existing structures shall be revieved for existing Code violations.

\section{PANT/NU CRITERTA}

Note: See the subsequent sections of this Manual for more specific critería.

A. Sprinklers in conveyor spaces inaccessible to firefighting equipment. Ceilings vith lay-in panels are considered to be inaccessible.

B. Adaptation of Code and NFPA standards to loading bridges, hangars, terminal buildings, etc.

c. Protection of airport buildings Erom potential fuel spillage fires.

D. Requirements for draperies, furniture, etc.

E. PvC pipes, ducts, conduits and insulation for vires shall not be used vithin bulldings.

\section{v. COORDIRATION VITH PACILTIIES}

A. Electrical: Nev pover requirements shall be indicated.

B. Vater supply: Coordination of any demand for chilled vater, high temperature vater, domestic vater, high pressure sprinkler supply vater, and connections to the fire protection loop, shall be fully described.

c. Any vork affecting the fuel lines shall be specified. 
1. GEVIERAL

A. The scope of the structural reviev shall comprise compliance vith the applicable codes, standards, and design criteria listed belov.

B. Computations shall be submitted wth all structural plans.

II. CODES MND RRGULATIONS

A. Nev York City:

1. New York City Buliding Code.

2. Rules and Regulations of the Department of Buildings, such as:

a. Resistance to Progressive Collapse Under Extreme Local Loads.

b. Design of Composite Construction vith Hetal Decks or Lightreight Concrete.

c. Structural Designs Based on Electronic Computer Cosputations.

d. Design and Installation of Curtain Vall Systems.

e. Kasonzy Parapet Valls.

B. New Jersey:

Nev Jersey Uniform Construction Code (NJuCC).

c. City of Yonkers:

The Uniform Fire Prevention and Building Code of Nev York State.

III. STANDARDS

AASBTO American Association of State Bighuay and Transportation OEflcials.

AREA American Railway Engineering Association. 


\section{PORT AUTBORTIY DESIGN CRTTERIA}

A. All structures, including those in Nev York Staie, shall be designed for earthquake zone 2 forces. BOCA provisions shall apply, unless more strlingent local lavs are adopted.

B. Roof Snor Load in New Jersey:

In calculating snov loads, BOCA "Ground Snov Load" shall be 25 psf.

c. Cellings:

1. Cement plaster ceilings - see Attachment $\mathbf{5 1 .}$

2. Lightveight ceilings in Nev Jersey - see Attachwent S2.

3. Lightveight ceilings in VTC - see Attachment $\mathrm{S3}$.

D. Vehicular Traffic (Airports):

1. Elevated roadways shall be deslgned for seisuic forces according to the "Guide Specifications for the Seismic Design of Bighvay Bridges" by AASBTO, or the relevant State DOT standards for earthquakes, whichever is stricter.

2. The minisu loading for departure and arrival ramps servicing passenger terminals shall be BS $15-44$.

Use AASETO design. All other ramps servicing cargo facilities or road overpasses: AASBTO design using BS2O minimus loading.

E. Highvay Signs and Luminaries:

Standard Specifications for Structural Supports for Bighvay Signs, Luminaires and Traffic Signals; American Association of State Bighway and Transportation Officlals (AASBTO).

F. Loading Bridges (Alrports):

1. Minimum Live Loads:

2. Minfmum Vind loading (WL):

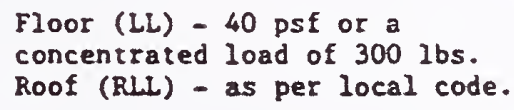

12.5 psf lateral for the extended (operational) mode (conbined vindvard and leevard pressure).

25 psf lateral for the retracted (stowed) mode (combined vinduard and leevard pressure). 
3. Hinimum Load Combinations:

$$
\begin{array}{ll}
\text { a. Extended: } & \begin{array}{l}
\mathrm{DL}+L L+R L L \\
\mathrm{DL}+L L+1 / 2 R L L+V L \\
\\
\mathrm{DL}+\mathrm{WL}
\end{array} \\
\text { b. Retracted: } & \begin{array}{l}
\mathrm{DL}+\mathrm{RLL} \\
\mathrm{DL}+\mathrm{RLL}+\mathrm{VL} \\
\mathrm{DL}+\mathrm{WL}
\end{array}
\end{array}
$$

4. Miniạum Stability Factors: Overturning 1.5

$\begin{array}{ll}\text { Sliding } & 1.5 \\ \text { Uplift } & 1.5\end{array}$

5. Codes (except vhere stricter requirements are noted):

a. Nev Jork City - Nev York City Building Code.

b. Nev Jersey - The Construction Code (BOCA).

\section{v. DETAILS OF STRUCTURAL REVIBT}

The following are representative of detalls reviewed:

A. The design calculations shall Include but not be I1mited to:

1. Design criteria and applicable codes.

2. Reference Standards.

3. Materials.

4. Type of construction and foundations.

5. Design loads; including uind and other existing forces.

6. Machinery and equipment loads in excess of 1000 Ibs. including an evaluation of any potential vibration.

7. Allowable soil bearing capacity.

8. P1le type and capacity.

9. Design analysis and drawings of all connections other than AISC standard framed or seated beam connections.

10. Analysis and sketches of expansion joints.

11. Design of bracing systems and rigid joints.

12. Wind drift and deflections. 
13. Ponding.

14. Computer print-outs and users' manuals.

15. Investigation of superimposed loads from adjacent construction on structure and foundation.

16. Investigation of existing structural systew and foundations under additional loads due to alterations.

17. There it has been established that post-construction settlements of foundations are to be monitored, the monitoring program, the lirits of such differential settlement that the structure can tolerate, and the necessary adjustments shall be subaltted for revlev.

B. Dravings shall include but not be linited to the folloving information:

1. Design Code and Reference Standards.

2. Katerials.

3. Design l1ve loads, wind and other forces.

4. Machinery and equipwent loads in excess of $10001 \mathrm{bs}$. including footprints or support layout(s) plus technical details of vibration isolators.

5. Allovable soil bearing capacity.

6. Pile type, capacity and winimum tip elevation.

7. Colum schedule shoving accumulated design load at each level for dead and live loads.

8. Stress dlagram(s) for trusses.

9. Datus and ground water elevations.

10. Iypical moment connection details.

11. Details of non-standard connections.

12. Listing of eaterials subject to controlled inspection.

13. Construction sequence. 
C. Speciflcations:

1. Shall clearly define the scope of vork and terials required for the contract.

2. Shall include liaitations, restrictions or conditions due to existing environs and/or requirements for the methods of construction or staging. 


\section{GENERAI}

The purpose of this section is to outline:

A. The requiresents for acceptance (approval) of waterials, assemblies, forms, methods of construction, and the intended use of equipwent.

B. The requirements for inspection of waterials and asseablies and construction.

\section{CODES AND ERGULATIONS}

A. Nev Iork City:

1. Nev Iork City Building Code and its Reference Standards.

2. Nev Iork City Fire Prevention Code and Directives.

3. Nev York City Electrical Code.

4. Nev York City Local Laus.

5. Rules of the Board of Standards ta Appeals (BSEA).

6. Nev Iork State Labor Lavs.

7. Nev York State Muliple Dvelling Lavs (Botels).

8. Nev York State Energy Conservation Construction Code.

9. Directives and Meworanda of the Department of Bulldings.

B. Nev Jersey:

1. Neu Jersey Uniform Construction Code, 1ts bulletins and the sub-codes (BOCA, etc.) vith their Supplements and Reference Standards.

2. Applicable Flood Controls.

3. New Jersey Uniform Flre Code.

c. The City of Yonkers:

The Uniform Fire Prevention and Building Code of Nev York State. 
III. NET YORK CITI

A. Approval/Acceptance of Materials, Equipment, etc.:

No material, assemblies, forms, method of construction, equipment, machinery and devices will be acceptable for the intended use unless:

1. Accepted by the Code rest method by the Materials and Equipment Acceptance (MEA) division of the Office of the Comissioner of the Buildings Departwent of Nev York City.

2. Or approved by the New York Clty Board of Standards and Appeals (BSEA).

Resolutions of MEA or BS\&A shall be submitted for reviey along with other review documents. Manufacturers' or distrfbutors' letters shall not be acceptable.

The above requirements are abstracted from New York City Bullding Code Sections C26-106.1, 106.2, 107.1 and 107.2.

B. Inspection:

Controlled Inspection (Code Sections C26-106.3 and 107.3):

1. All materials, equipment, and construction, designated by the Code for "controlled Inspection" shall be inspected and/or tested ro verify compliance vith the Code.

2. Controlled inspection shall be made and vitnessed by or under the direct supervision of a registered architect (RA) or professional engineer (PE), retained by the tenant and acceptable to the architect or engineer responsible for the plans. The inspecting RA or $\mathrm{PE}$ shall be independent of the contractor.

3. All items subject to controlled inspection shall be listed on the title sheet of the plans, or the sheet immediately following.

The following 11 st contains items subject to controlled inspections, as vell as the Items' relevant Code sections, where applicable:

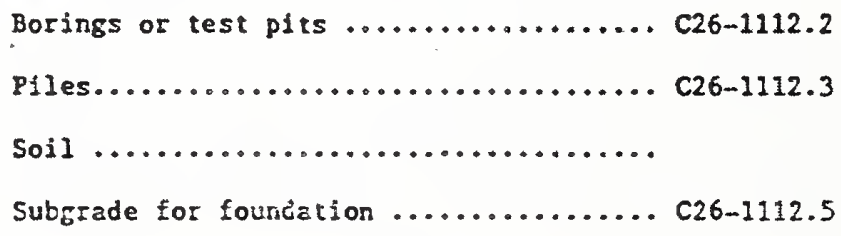




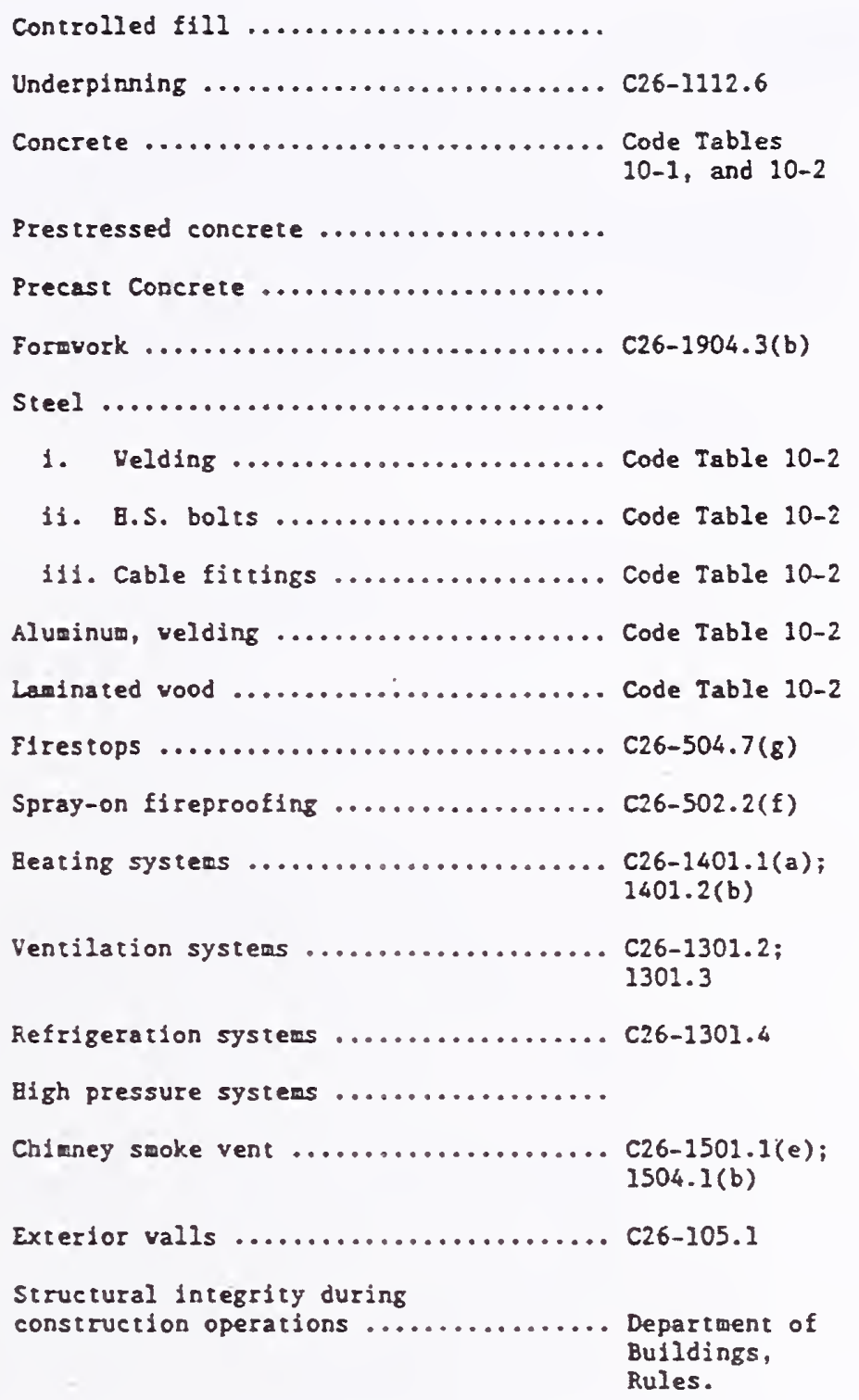


TV. NEV JERSET

A. Approval/Acceptance of Materials, Equipment, etc.:

Acceptance of materials, assemblies, equipment, forms, methods of construction, etc., shall be based on authenticated reports from approved agencies indicating compliance with accepted engineering pracilice. See BOCA Building Code Section 1300, BOCA Hechanical Code Section 4.02.0, and the Appendix A of these Codes for approved agencies and testing standards.

Note: The P.A. Engineering Department has accepted approvals frow the New York City Board of Standards \& Appeals (BSAA) and Haterial and Equipwent Acceptance (MEA). See III.A above.

B. Inspection:

Construction Control - as per NJucC 5:23-2.21(c):

1. The tenant shall assign a "responsible person in charge of the vork" (PPIC), who shall be responsible for:
a. Reviey and approval of all documents pertaining to the construction phase.
b. Verfflcation of all controlled materials.
c. Special inspection of critical construction components (see list in paragraph 2 below).
d. Necessary services to determine that the vork is proceeding according to the approved documents.
e. At the completion of vork, the RPIC shall subuit a report to the P.A. attesting to the satisfactory completion of the project, including a list of deviations from the approved documents.

2. The folloving is the list referred to in the requirement for "special inspection of critical construction components," stated in item $B .1(c)$ above. Effort has been made to make this list as inclusive as possible based on the current codes adopted by the NJucC. Other construction aspects subject to "special inspection" as required by these codes, that have been onitted by this list must also comply. These inspections shall be performed by a licensed engineer or a registered architect, licensed to practice in the State in wich the work vill occur, and the reports submitted to the P.A. 
a. Foundations:

1. Boring operations...........BOCA, Section 1203.1

i1. Subgrade for foundations.

1iz. Controlied Eill.

iv. Piling (installation, testing, cut-off and tip elevations)..................... Section 1213.12

v. Support of adjacent properties.

vi. Underpinning.

vil. Foundations and valls up to grade prior to backfllling.

b. Structure:

i. High strength bolts - see BOCA Building Code Table 1308.3.2.

11. Velds.

111. Concreting operations - see BOCA Building Code Table 1308.4 .4 .

c. Plumbing:

i. Underground services.

11. Rough piping.

1i1. Water services.

iv. Sever.

v. Septic service.

vi. Stors drains.

d. Electrical:

1. Rough wiring.

ii. Panels and service installation.

ii1. Insulation installation.

e. Mechanical equipment systems.

E. Eeat producing systems. 
3. The contractor shall, at the completion of the construction, certify that the construction has been executed in substantial accord vith the approved documents, with all pertinent deviations speciflcally noted. 
TEE PORT AUTEORITY OF NEV YORK \& NEU JERSEY

\author{
HEMOR A N D U H
}

To: H. Biancamano, R. Catlin, P. Ciano, E. Chalon, G. Doherty, E.K. Farrely, W. Fife, P. Galya, R. Goode, G. Jensen, J. Kau, J. Miller, M. Ronis, 5. Smolenski, E. Takla, V. Volpicelli

From: Ennala Ramabhushanam

Date: October 23, 1990

Subject: TENANT CONSTRUCTION REVIEW MANUAL - AMENDMENT $\$ 1$

Copy To: h. Erociner, P. Cooper, V. Dovletian, E. Fasullo, M. Poliacof, 0 . Suros, TCRU Staff

Listed below are the pages of the Tenan: Construction Review Manual that are amended and must be replaced by the pages attached herewith. The changes are highlighted with an *.

Pages 6-2,

9-5, (re-enumeration of paragraphs)

$9-6$

$10-6$ (nes page)

$11-3,11-5$

Please insert this sheet in the front of the Manual.

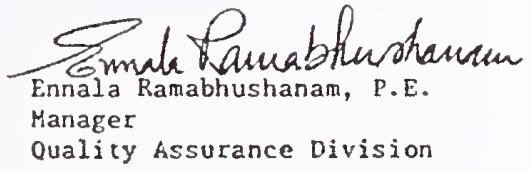


IV. PORT AUTHORITY DESIGN CRITERIA

is. All structures, including those in New York state, shall be designed for earthquake zone 2 forces. gocA provisions shall apply, unless more siringent local laws are adopted.

B. Roof Snow Load in Nev Jersey:

In calculating snow loads, BoCh "Ground Snow Load" shall be 25 psf.

c. Ceilings:

1. Cement plaster ceilings - see Attachment $\$ 1$.

2. Lightveight ceilings in New Jersey - see Attachment 52 .

3. Lightweight ceilings in WTC - see Attachment $\$ 3$.

* 4. For the suspension of lightweight ceilings to resist earthquake forces see ASTM ESBO.

D. Vehicular Traffic (Airports):

1. Elevated roadways shall be designed for seismic forces according to the "Guide Specifications for the Seismic Design of Highway Bridges" by hASITO, or the relevant State DOT standards for earthquakes, whichever is stricter.

2. The mininum loading for departure and arrival tamps servicing passenger terminals shall be HS $15-44$. Use AASHTO design. All other ramps servicing cargo tacilities or road overpasses: AAskro design using US20 minimum loading.

E. Highway Signs and Luminaries:

Standard Specifications for Structural Supports for Highway Signs, Luminaries and Traffic Signals; American Association of State Highway and Transportation Officials (ABSUTO).

F. Loading Bridges (Airports):

1. Minimum Live Loads:

2. Minimum Vind loading (VL):

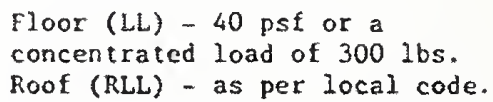

12.5 psf lateral for the extended (operational) mode (combined windward and leeward pressure).

25 psf lateral for the retracted (stowed) mode (combined windward and leeward pressure). 
Appendix D

Tenant Construction ReView Manual - 1997

Engineering Department Quality Assurance Divigion

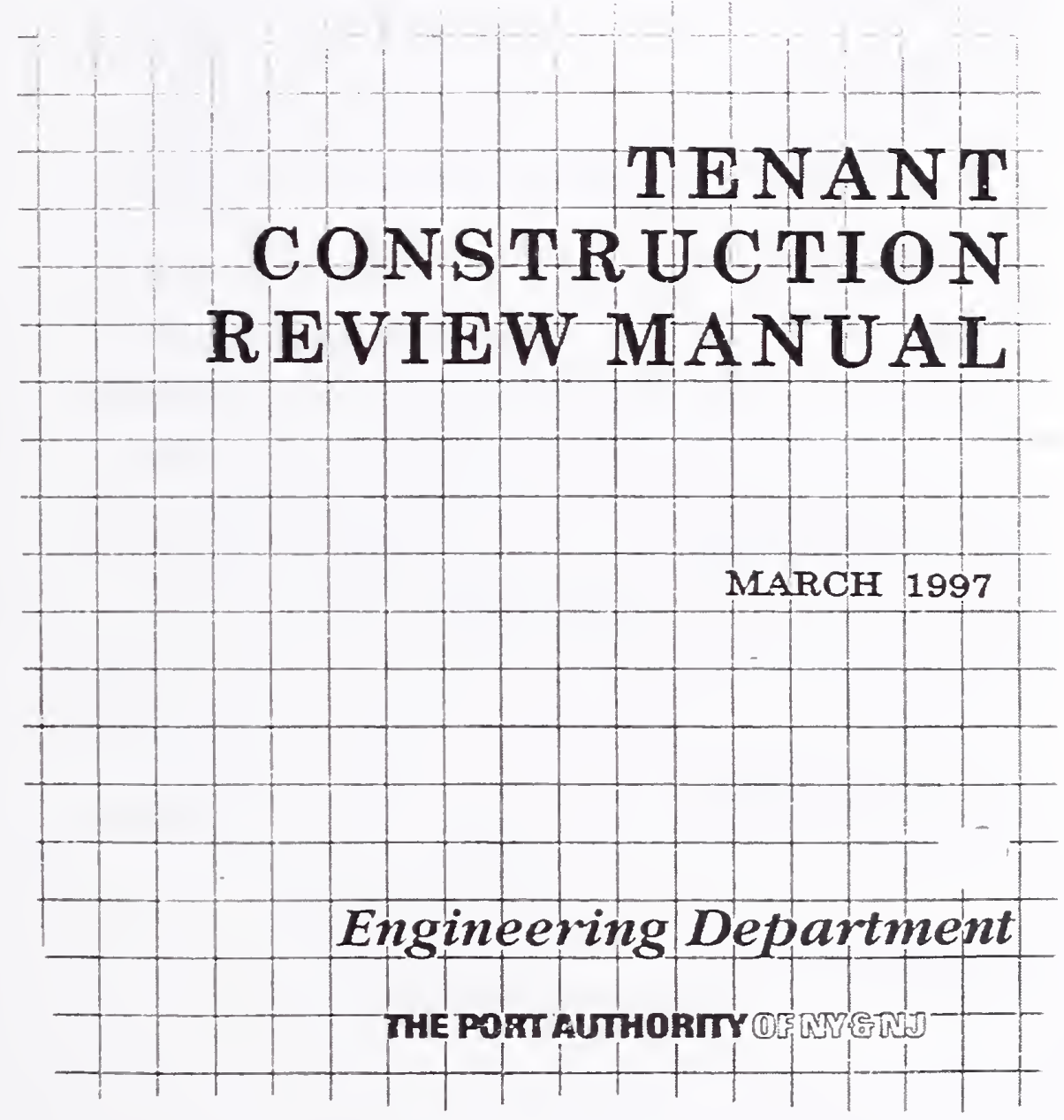

Reproduced with permission of The Port Authority of New York and New Jersey. 
SECTION 1

\section{TABLE OF CONTENTS}

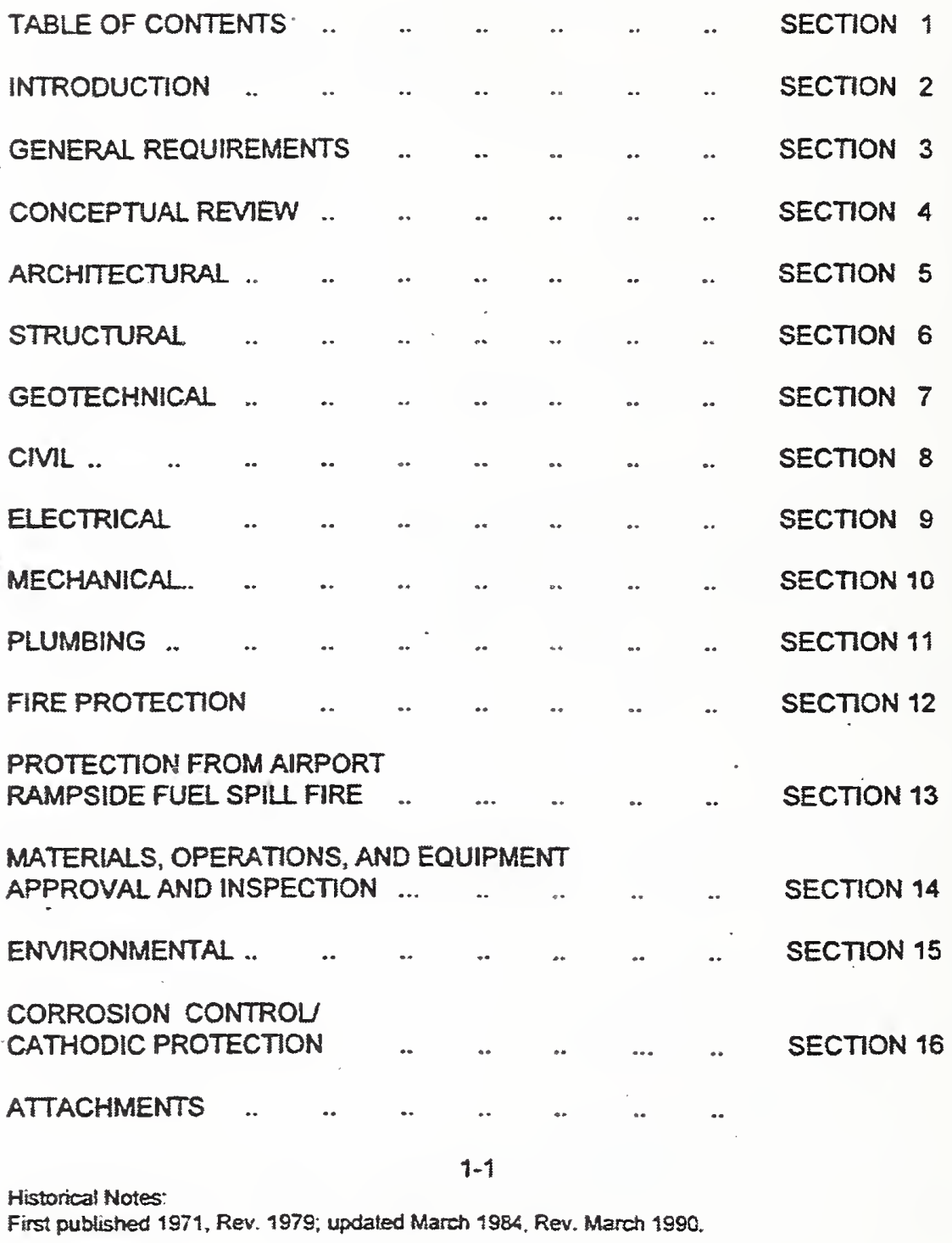

First published 1971, Rev. 1979; updated March 1984. Rev. March 1990. 


\section{LIST OF ATTACHMENTS}

A1 Standard for Interior Plastic Signs

A2 Specifications Governing the Flammability of Drapery and Curtain Materiaks in Unsprinklered Areas.

A3 Specifications Goveming the Flammability of Upholstery Material and Plastic Fumiture in Unsprinklered Areas.

A4 Specifications Governing the Flammability of Plastic Laminate and Wood Veneer Fumiture.

S1 Plaster Ceiling Design Standards.

S2 Lightweight Ceiling Design Criteria.

S3 Modifications to the New York City Building Code Earthquake Loads.

C1 Civil Standard Details.

C2 Protection of Underground Pipes.

M1 Port Authority Bus Terminal - HNAC Design Criteria

E1 Port Authority Bus Terminal - Electrical Design Criteria.

F1 New York City Municipal Fire Alarm.

RFS-1 Airport Rampside Clearances. 


\section{SECTION 2}

\section{INTRODUCTION}

This Manual presents the technical criteria to be followed by Tenants, and their architectural and engineering consultants, at all Port Authority (PA) facilities in connection with construction work undertaken by a Tenant. These technical criteria are in addition to other requirements contained in the lease agreement between the Port Authority and the Tenant. This Manual also covers the Port Authority Engineering Department's scope-of-review of the design documents (plans, specifications, calculations and other documents) submitted by Tenants in connection with proposed construction or alterations. It shall not be deemed to imply that there will not be additional reviews by other Port Authority Departments.

The Design Standards (Tenant Construction Review) Unit of the Engineering Department's Quality Assurance Division will review the Tenant Construction or Alteration Application submitted by the Tenant in accordance with the criteria contained in this Manual. The responsibitity for architectural and engineering design shall remain with the Tenant's Architect or Engineet (AVE) of record. The Design Standards Unit will not impose design solutions but will only comment on the design presented.

Reviews will not address the proposed aesthetic or functional aspects of the design.

Construction documents for Tenant construction or alterations will be reviewed by the Design Standards Unit for compliance with all applicable Codes and Port Authority Technical Standards. In the absence of a specific code provision, this Manual sets forth the applicable standards to be followed by Tenants except as may otherwise be required. All design documents shall reflect the existing construction as well as the proposed work in order to determine compatibility with existing facility conditions.

In this regard, a list of alt reference documents and guidelines which the Facility has provided to the Tenant, and which affect the design, should become an integral part of he Tenant's contract document submission. If the review process will be aided by the inclusion of these reference documents, such documents should also be included in the submission. 


\section{SECTION 3}

\section{GENERAL REQUIREMENTS}

1. All proposed Tenant construction shall be submitted for review, in completed form, accompanied by a "Tenant Construction or Alteration Application," Form PA531, which shall be provided to the Tenant by the appropriate Port Authority line department.

The PA line department shall forward all tenant submittals to the Engineering Quality Assurance Division with a completed Tenant Alteration Application Review Request Form, PA2127, indicating the technical disciplines to be reviewed for the submitted project(s).

11. The design documents, such as drawings, reports, computations and specifications, required in connection with the proposed construction, shall be attached to, and form a part of, the Tenam Construction or Alteration Application, and shall reflect the existing construction as well as the proposed work. The design documents shall be sealed and signed by the architect or engineer of record licensed to practice in the State in which the proposed construction is to be performed. The architect/engineer indicated on the Application shall be considered the Architect or Engineer (AVE) of record.

The AE of record is responsible for assuring that the documents prepared and submitted by other consultants are property coordinated.

Where other consultants have been acknowledged by the AVE of record, either in the Tenant Alteration Application of on the drawings, said consultants may seal and sign the documents they have prepared.

Where the Tenamt retains two or more independently functioning consultants, they each become an AE of record for their respective scope of work. Each consultam will be required to submit a separate Tenant Alteration Application, and each consultant shall seal and sign their respective documents.

Responsibility for design or code compliance shall not be delegated to contractors. 
11I. All revisions to previously submitted documents shall be property identified, and shall be accompanied by a brief description of the revisions.

N. All voluntarily installed Fire Protection systems, including, but not limited to sprinklers, alarms, etc., shall comply with the provisions of the applicable Building Codes for such systems.

V. Fire protection plans, as described in the New York City Building Code Section 27-228.1 et seq., shall be filed for review along with other design documents for construction projects at all Port Authority facilities. After approval of the project for construction, and before a Permit to Occupy or Use is issued, the Tenant shall submit one (1) copy of these plans to the Manager of the Facility where the project is located, one (1) copy to Risk Management, and two (2) copies to the Quality Assurance Division of the Engineering Department.

v. In accordance with the policy of the Port Authority of New York and New Jersey, the Tenant shall comply with the provisions of all federal, state, municipal, local and departmental laws, ordinances, rules, regulations and orders that may affect the construction or alteration contract and all individuats involved therein. Where stricter requirements apply, i.e., those contained in the specifications or drawings, they shall be followed. The Tenant, or designated agents, shall not apply for any variance, license, waiver or permit in the name of or on behalf of the Port Authority. 


\section{SECTION 4}

\section{CONCEPTUAL REVIEW}

\section{GENERAL}

At the Tenant's request, a Conceptual Review will be performed to supplement the consultants' feasibility studies. These reviews will inform the consultants of established design criteria, pre-existing conditions that determine code compliance, and Port Authority requirements affecting the proposed work. The conceptual review shall be limited to fundamental concepts and items related to the criteria in this Manual that may significantly affect the design. The review will not address aesthetics or functional design.

Submitted conceptual plans shall indicate conformance to the applicable codes and design criteria.

The scope of the Conceptual Review may include the items enumerated in the following paragraphs:

\section{BUILDING CODE}

A. Ocoupancy group and construction classification of the new, attered, and adjusted areas.

B. Fire protection of spaces in the building as it applies to ratings of interior separations, shafts, exterior walls, and sprinkler requirements.

C. Egress: Occupant load and adequacy of egress shall be established or the Tenant's architectlengineer may list the sections of the applicable Code on which the design is based. New Tenant egress scheme(s) shall be coordinated with existing conditions.

D. Special structural conditions, including foundations. 
E. Special or unusual mechanical or electrical problems affecting environmental, energy, or power requirements.

F. Deviations from Code requirements.

G. Existing structures shall be reviewed for existing Code violations.

III. PANYNJ CRITERIA

See the subsequent Technical Sections of this Manual for specific criteria.

\section{IV: COORDINATION WITH FACILITES}

A. Electrical: New power requirements shall be indicated.

B. Water supply; Coordination of any demand for chilled water, high temperature hot water, domestic water, high pressure sprinkler supply water, and connections to the fire protection loop, shall be fully described.

C. Any work affecting fuel lines shall be indicated. 


\section{SECTION 6}

\section{STRUCTURAL}

\section{GENERAL}

A. The scope of the structural review shall comprise compliance with
the applicable Codes, standards, and design criteria listed below.

B. Computations shall be submitted with all structural plans.

II. CODES AND REGULATIONS

A. New York City:

1. New York City Building Code.

2. Rules of the City of New York, Trite 1, Department of Buildings.

B. New Jersey:

New Jersey Uniform Construction Code (NJUCC).

C. City of Yonkers:

New York State Uniform Fire Prevention and Building Code.

III. STANDARDS

AASHTO

AREA

ANSIEELATLA-222-E Structural Standards for Steel Antenna Towers and Antenna Supporting Structures.

$6-1$ 


\section{N. PORT AUTHORITY DESIGN CRITERIA}

A. In the absence of provisions for earthquake design in the New York State Uniform Fire Prevention and Building Code, the New York City Building Code Shall be used for earthquake design in the City of Yonkers.

For modifications to the New York City Building Code Earthquake Loads, See Attachment S3.

B. Floors in certain areas of the Port Authority Bus Terminal South Wing are of light weight low strength concrete construction. Concrete anchors are not permitted in these light weight slabs for the attachment of hangers for supporting ducts, utilities, ceilings, and other miscellaneous loads. These loads shall be supported directly from floor beams or supplementary framing connected to the floor beams. Information regarding the locations of the light weight slabs can be obtained from the Facility Tenant Liaison Office.

In areas where concrete inserts are permitted, only approved type stainless steel anchors rated for shock and vibration loads and elevated temperature shall be used.

c. Ceilings:

1. Plaster Ceiling Design Standards - see Attachment S1.

2. Lightweight Ceiling Design Criteria - see Attachment $\mathbf{S 2}$.

D. Vehicular Traffic:

1. Elevated roadways shall be designed for all loadings, including seismic effects, in accordance with the AASHTO "Standard Specifications for Highway Bridges" and the relevant State DOT Standards. In New Jersey, roadways providing access to interstate freight shall be designed for HS 25 loading.

2. The minimum loading for the departure and arrival ramps servicing airport passenger terminals shall be HS 15-44 
AASHTO highway loading. All other ramps servicing cargo facilities or road overpasses shall be designed for HS20 AASHTO highway loading.

E. Highway Signs and Luminaries:

Standard Specifications for Stuctural Supports for Highway Signs, Luminaries and Traffic Signals; American Association of State Highway and Transportation Officials (AASHTO).

F. Aircraft Loading Walkways (Airports):

1. Minimum Live Loads:

Floor (4L) -40 psf or a concentrated load of 300 lbs. Roof (RL) as per local code.

2. Minimum Wind Loading (ML) 12.5 psf lateral for the extended (operational) mode (combined windward and leeward pressure). 25 psf lateral for the retracted (stowed) mode (combined winoward and leward pressure).

3. Load Combinations:
a. Extended: $\mathrm{DL}+\mathrm{LL}+\mathrm{RU}$
$D L+L L+1 / 2 R U+W L$
$D L+W L$
b. Retracted:
$D L+R L L$
$\mathrm{DL}+\mathrm{RL}+\mathrm{WL}$
$D L+W L$

4. Minimum Stability Factors: Overtuming 1.5

Sliding $\quad 1.5$

Uplift $\quad 1.5$

6-3 


\section{DETAILS OF STRUCTURAL REVIEW}

The following are representative of items reviewed:

A. The design calculations shall include but not be limited to:

1. Design criteria and applicable Codes.

2. Reference Standards.

3. Materials.

4. Type of Constriction and foundations.

5. Design loads, including wind and other forces.

6. Machinery and equipment loads in excess of $1000 \mathrm{lbs}$. Including an evaluation of any potential vibration.

7. Allowable soil bearing capacity.

8. Pile type and capacity.

9. Design and details of all connections other than AISC standard framed or seated beam connections.

10. Location and details of expansion joints.

11. Bracing systems and moment-resisting frames.

12. Deflections and wind drift.

13. Ponding.

14. Investigation and superimposed loads from new construction on existing structure and foundation.

15. Investigation of existing structural system and foundations under additional loads due to alterations.

16. Where it has been established that post-construction settlements of foundations are to be monitored, the 
monitoring program, the limits of differential settlement that the structure can tolerate, and the necessary adjustments shall be submitted for review.

B. Drawings shall include, but not be limited to, the following information:

1. Applicable Code and Reference Standards.

2. Materials.

3. Design live loads, wind, and other forces.

4. Machinery, equipment, and other concentrated loads in excess of $1000 \mathrm{lbs}$. Including footprints or support layout(s).

5. Allowable soil beaning capacity.

6. Pile type, capacity, and minimum tip elevation.

7. Column schedule showing accumulated design load at each level for dead and live loads.

8. Stress diagram(s) for trusses.

9. Datum and ground water elevations.

10. Typical moment connection details.

11. Details of non-standard connections.

12. Construction sequence.

C. Specifications shall include, but not be limited to:

1. The scope of work and materials required for the construction or alteration.

2. Limitations and restrictions due to the existing conditions and/or requirements for the methods of construction or staging. 


\section{ATTACHMENT S3}

\section{MODIFICAITONS TO THE NEW YORK CITY BUILDING CODE EARTHQUAKE LOADS}

Revise Table No. 23-P of RS 9-6 by:

a. Adding after ll.1.b.

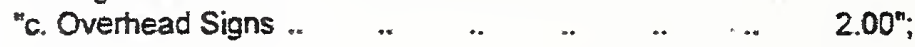

b. Adding after II.3.

"4. Anchorage for suspended ceilings weighing more than 4 psf

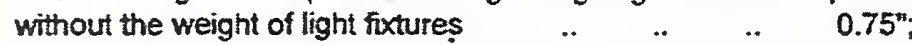

c. Adding after III.1.

2. Elevator and counterweight guardrails and supports $1.25^{\mathrm{m}}$

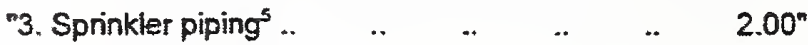

"4. Gas and high hazard piping $\quad . . \quad$.. $\quad . \quad . \quad 2.00^{\prime \prime}$

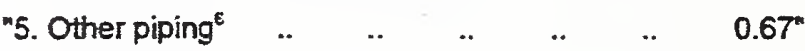

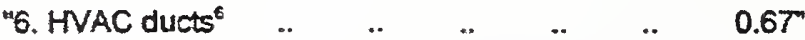

d. Adding the following notes after Note 4 at the bottom of the table:

"5. The design of seismic restraints for sprinkler piping in compliance with NFPA 13 using a design acceleration of 0.15 is acceptable in lieu of compliance with these provisions.

6. Seismic restraints are not required for any of the following conditions for other pipe systems of HVAC ducts:

i. Piping or ducts suspended by individual hangers 12 inches or less in length from the top of the pipe or ducts to the supporting structure.

ii. Piping in boiler and mechanical rooms which has less than 1-1/4 inches inside diameter. 
iii. Piping in other areas which has less than $2-1 / 2$ inches inside diameter.

iv. Ducts which have a cross-section area less than 6 square feet." 


\section{SECTION 14}

MATERIALS, OPERATIONS, AND EQUIPMENT APPROVAL AND INSPECTION

\section{GENERAL}

The purpose of this section is to outline:

A. The requirements for acceptance (approval) of materials, assemblies, forms, methods of construction, and the intended use of equipment.

B. The requirements for inspection of materials, assemblies, and construction.

I CODES AND REGULATIONS

See the Technical Sections of this Manual

\section{NEW YORK CITY}

A. ApprovalAcceptance of Materials, Equipment, etc.:

No material, assemblies, forms, method of construction, equipment, machinery, and devices will be acceptable for the intended use unless:

1. Accepted by the Code test method by the Materials and Equipment Acceptance (MEA) Division of the New York City Department of Buildings.

2. Or, previously approved by the New York City Board of Standards and Appeals (BS\&A).

MEA or BS\&A resolutions of approval shall be submitted for review along with other review documents.

Manufacturers' or distributors' letters are not acceptable. The above requirements are abstracted from New York City Building Code, Sections 27-130, 27-131, 27-134, and $27-135$. 
B. Inspection:

Controlled Inspection (Code Sections 27-132 and 27-136)

1. All materials, equipment, and construction designated by the Code for "controlled inspection" shall be inspected and/or tested to verify compliance with the Code.

2. Controlled inspection shall be made and witnessed by or under the direct supenision of a registered architect (RA) or professional engineer ( $P E)$, retained by the tenant and acceptable to the architect or engineer responsible for the plans. The inspecting RA or PE shall be independent of the contractor.

3. All items subject to controlled inspection shall be listed on the title sheet of the plans, or the sheet immediately following.

The following list contains items subject to controlled inspections, as well as the items' relevant Code sections, where applicable.

Effort has been made to make this list as inclusive as possible. Other items subject to controlled inspection, as required by NYC Building Code, that have been omitted in this list must also comply.

Borings or test pits $27-720$

Piles $27-721$

Subgrade for foundation $27-723$

Controlled fill $27-679(a)$

Underpinning $27-724$

Concrete

Code Tables 10-1, 10.2

Formwork

27-1035(b) 
Steel:
i. Welding
Code Table 10.2
ii. H.S. bolts
Code Table 10-2
iii. Cable fittings
Code Table 10-2

Aluminum, welding

Code Table 10-2

Laminated wood

Code Table $10-2$

Masonry

Code Table $10-2$

Exterior Wall insulation

and Finish Systems $27-335.1(c) 13$

Firestopping

$27-345(h)$

Spray-on fireproofing $27-324(0)$

Heating and combustion 27-793(a), equipment 27.794(b)

Ventilation systems $27-779,27-780$

Refrigeration systems $27-781$

High pressure systems Department of Buildings, Rules Section 20-02(b)(2)(i)

Chimney smoke vent $27-856(e)$ $27-879(\mathrm{~b})$

Welding of gas distribution piping RS-16, P115.8(h)

Curtain/Panel Wall

Rules of the City of New York, Titte 1, Department of Buildings, Chapter 32. 
Structural integrity during ..... construction operations
Rules of the City of New York, Titte 1, Department of Buildings, Rules, Chapter 16.

\section{N. NEW JERSEY}

A. ApprovaVAcceptance of materials, Equipment, etc.:

1. Acceptance of materials, assemblies, equipment, forms, methods of construction, etc., shall be based on certified test reports from approved agencies. See BOCA Building Code Chapter 17 and BOCA Mechanical Code Chapter 4, as amended by New Jersey Uniform Construction Code (NJUCC).

Note: Approvals from the New York City Material and Equipment Acceptance (MEA) Division are acoeptable. See Paragraph III.A.1.

2. See NJUCC, Section 5:23-4.26 for certification of building elements, such as trusses, fire walls, fire separation walls, wall panels, pre-stressed/prefabricated floor or roof panels and pre-engineered structural frames.

B. Inspection:

Construction Control - as per NJUCC Section 5:23-2.21(e):

1. The tenant shall assign a "responsible person in charge of the work" (RPIC), who shall be responsible for.

a. Review and approval of all documents pertaining to the construction phase:

b. Verification of all controlled materiats.

c. Special inspection of critical construction components (see list in paragraph 2 below). 
d. Necessary services to determine that the work is proceeding according to the approved documents.

e. At the completion of work, the RPIC shall submit a report to the P.A. attesting to the satisfactory completion of the project, including a list of deviations from the approved documents.

2. All items subject to "special inspection," stated in item B.1.C, shall be listed on the title sheet of the plans, or the sheet inmediately following.

The following is a list of items subject to "special inspection of critical construction components." Effort has been made to make this list as inclusive as possible based on the current codes adopted by the NJUCC. Other construction items subject to "special inspection" as required by these codes that have been omitted in this list must also comply:

a. inspection of Fabricators

BOCA, Section 1705.2 as amended by NJUCC.

b. Steel Construction:

i. Material Receiving BOCA, Section 1705.3.2.

ii. Erection: Installation of High strength bolts. BOCA, Section 1705.3.3.1.

Welding BOCA, Section 1705.3.3.2.

Details BOCA, Section 1705.3.3.3. 
c. Concrete Construction:

i. Materials

BOCA, Section 1705.4.1

ii. Installation of Reinforcing and Prestressing Steel BOCA, Section 1705.4.2.

iii. Forrnwork BOCA, Section 1705.4.3.

iv. Concreting Operations... BOCA, Section 1705.4.4.

v. Inspection during

Prestressing BOCA, Section 1705.4.5.

vi. Manufacturer of Precast Concrete BOCA Section 1705.4.6.

vii. Erection of Precast Concrete BOCA Section 1705.4.7.

d. Masonry Construction BOCA, Section 1705.5.

e. Wood Construction BOCA, Section 1705.6

f. Foundations:

Prepared fill BOCA, Section 1705.7

Pile foundations BOCA, Section 1705.8

146 
Pier foundations

BOCA, Section 1705.9

g. Wall panels and veneers

BOCA, Section 1705.10

h. Sprayed fire resistive materials BOCA, Section 1705.12

i. Exterior insulation and finish systems BOCA, Section 1705.13.

j. Special Cases

BOCA, Section 1705.14 
Appendix $\mathrm{E}$

STANDARDS FOR STRUCTURAL INTEGRITY INSPECTION OF WTC TOWERS A \& B

\section{WTC4098 \\ Infrastructure Engineering Design Division \\ Standards for Structural Integrity Inspection of the World Trade Center Towers $A$ and $B$}

March 1986 
WORLD TRADE CENTER - BUILDINGS 1 AND 2 STRUCTURAL INTEGRITY STANOARDS 
TABLE CE CONTENES

I. INTRODUC:ION

A. Purpose, Character anc Scope of the Program

- gizst Approach - Stacistical Inspections

2. Second Approach - Keports

3. Third approach - Continued Measurements

3. Seedback and Revision

IZ. GENERAL DESCRIPIION OF THE BLTLDINCS

III. PRENCIPAL STRUCTIAAL SYSTEMS AND ELEMENTS 5

A. Structural Systers

B. Symetry

C. Redundancy

D. Dampers

E. Shaf:erall

IV. ENSPECTION PROGRAY

A. Visual Inspections

1. Periodic Inspections

2. Occasional Inspections, Monitoring of Reports

B. Periodic Measurements

1. Sacural Erequencies - Towers

2. Natural Frequencies - Tr Mast

3. Natural Frequencies - Fioor Construction

4. Visco-Elastic Damers

5. Plumbness and Level

V. INSPECIION PERSONNEL - IN- HOUSE

A. Inspection Supervisor

3. Leacer Qualifications

C. Inspector Qualificasions

Y. OOTSIJE CONSULTANTS AND SJPPLIERS OF SPECIAL SERVICES 16

Ni:. RECORD-REEPING AND EOLLOW-GP PROCEDURE

A. Seructural sieel Defects and Signs of Distress

l. Bust

2. Cracks

3. Bucikles and Rinks

4. Connection and Join: Defects

5. Alignent, Excessive Deflection or Bowing

6. Paint

3. Reinforced Concrete Defects and Signs of Distress

b. Scaliag

2. Cracking

3. Spalling 
TABLE OF CONTENTS (CONTINLED)

C. Iaspection Records

1. Identification

2. Description

3. Special Reports

4. Urgency

D. Measurements and Test Records

1. Feriods of Vibration, Towers and Mast

2. Floor systems

3. Acditional Data

4. Plumbness and Level

E. Periods of Vibration

1. Exterior walis

2. Floor Systems

VIII. EXCLUDED HORX

IX. REFERENCES

APPENDIX A - STRUCTURAL INTEGRITY PROGRAY

TELEVISION ANTENNA MAST

APRENOIX B - FIBER ORTIC BORESCORE SUPRLIERS

APPENDIX C - TABLES, FIGURES AND DRAUINGS

Table I: Eccentrically-Braced Colums

in Elevator Shafts

Plan Details for Table I

Figure 1: Suggestad Locations of Acceleromerers

for Measurement of Tower Natural Frequency

Figure 2: Zones for Floor Natural Frequency Measurement

Exterior wall to Floor 9 Elevations

IV Mast Support Elevations 


\section{INTRODUCTION}

A. Purpose, Character and Scope of the Program

These staadards are tesigned to assige che port Authority in the evaluation of the on-going structural integrity of the tuin towers of the forld Irade Center, New York. To date, che cowers have perforaed well, and atcenance costs are reported to be as anticipated. Further, tenat complaints of structure wotion, perhaps the largest gingle predicator of excessive swaying motion, are reforted to be negligible. Stili, should degrsiation of the struccural syster take place with :ime, remedial action is essential. These scandards, then, are designed $=0$ anticipace degradation, should it occur, and to allow for systematic repaí.

The standards make use of three separate approaches to the froviding of a suitatle frsmework for the monitoring of the structural iategrizy o: WTC 1 and WIC 2...the two 110-story cowers of the vorid. Trade cencer:

1. First Approash - Stacistical Inspections

Under the first, periodic statistical visual inspections of selected structural components in higher-potential trouble areas will be rade. It is proposed that, izitially, chis work be accomplished by qualified outside consultants under PANYNJ managerent. In the Euture, where this course is judged to be advantageous this task can be periorted by PANKIJ in-house personnel. The periodis inspections will be supplemented by accasioral visual inspections made possible by the exposure to view of structure during cenant remodeling of general maincenance work. Every opporcunity should be used co cake advantage of chese pore-or-less random exposures of the structura? syscem. Occasional inspections would be done in-house where the involved area is not large enough :o justify the use of an oucside consuliant.

2. Second Approach - Reports

In the second approach, var ious reports are exarined as possible symptons of underlying structural problers. Maintenance reports of aon-gtructural repairs, water leakage and tenant complaints about unusual building dovement, vibration or noise are exarples of such repores. 
3. - Third Approach - Coneznaed Measuretents

In the thicd procedure, the performance of systems within the stracture is evaluated through che continutio aeasurement of movement or deformation, using appropriate tests and instruments. These systems range is size from zelatively saall individual components repeated any times throughout the buidings, co an entire tower scructure.

The accumulated inspection reports and measured test data in time will form a chronological record which cat be consulted in assessig the significance of observed strucrural conditions or measurements. The periodic inspection procedure is adapted fron the port Authoricy Engineering Department "Standards for In-depth Structural Integricy Inspection of tuildings." The other sections of the program are degigned to respond to needs dictated by the nacure of the specitic structures and the building occupancy, and so are waique to these cowers.

B. Feedback and Revision

It is anticipated that Eeedbaci from the application of the progras may generate changes in procedure and scope. These Standards then, are viewed as an evolving system, to be amended as needed. 


\section{GENERAL DESCRIPTION OF THE BUILOINGS}

The two tower buildings $t$ ise more than 1,400 feet above theit foumdations, 1,438 seet for WTC 1 and 1,432 seet for WTC 2. The TV mast zaiseg that height co 1,800 feet for HIC 1. Each tower has 111 floors, 116 framed levels inciuding below grade service levely, with nearly one acte of sace on a typical iloor.

The tovers were the Firgt in the new family of very tall buildings to use the exterior wallg 39 a thin tubular shell in structural steel; the tubular shell cancilevers from its foundacions to supply all of the needed resiscance to wind and earthquake forces and to stabilize the core againgt lateral buckling. Lateral strength is attained in this way without the need for conventional rigid-frane construction, and the story height is reduced to 12 Feet. Gravity loads are cartied by core and exterior columns.

Different grades (yield points) of sceel vere used to equalize the dead load stresses and shortening of the very tall colums while accoumocating imposed loads from wind and gravity. The mojor trusswork spanning the railroad tratks also used a variety of steel grades to produce uniform deflection. A roottop space frave in each tower controls the expansion and contraction due to unequal colurn temperacures, and provides also "root" for the 362 foot high FV mast now acop WIC 1 (provisions for a similar tower are incorporated into HTC 2).

The prefabrication of structural components was developed so a poirt aever before achieved in high-rise buildiags:

- The tubular shell of the outside walls is made lip of nearly 6,000 wall panels, generally 36 feet by 10 feet, three stories hish and encompasing three columns in width, which were stacked one above the other, the colum ends field bolted together, and the spandrels field bolied to the spandrels of adjacent paneis. In this way Eiajd welding was held to a minimum in chese members and connections subject to stress reversal from witd excitation. Some wall units were 56 feet by 10 feet and weigh as much as 54 tons.

- The prefabricated floor units in the rypical tenant floors of each cover were generally 20 feet wide, with 60 foot and 36 foot leagths on different sides of the building; each floor unit contained steel deck and electrical raceways. Double trusses span the 60 foot and 36 foot dizections; alternating perpendicular deck support nembers and tzansverse trusses fork 3 incegral part of the prefabricated Eloor uni:. The double truss webs extend above the deck to provide composite act on with the concrete, which was cast atiet installation of the pretabricaced floor units. Tbe trasverse zrusses reze connected to adjoising units to provide wo-way spanning action in the corners of the building and co provide bridging action (redundancy) ia aseas of one-way span. All cora areas and all of the mechanical floors in the cowers are framed with rolled structural steel sections. 
The site has wiscellaneous Eill and debris over the oid riverbed, wh the ground water level gveraging about 5 feet below existing grade. A siurry wll systen embeded in rock was used on the 3 itse perimeter to perait dewatering and excavation to rock for the project foundations without damaging adjacent structures. Rock anchors stabilized the wall during excavation. The pertater wall yystem participases in the carrying of lateral wind forces from the pial down to rock. 


\section{PRIYCIPAL STRUCTURA SYSTEMS AND ELEMENTS}

A. Struczural Systers

The exterior walls are frased with closely-spaced columns and deep spandrels, acting effectively as a cubulat shell to resist all lateral forces and to share in supporting gravity loads. The exterior colums are spaced 3 feet 4 inches on center in the supersteucture. columns 10 Eeet on center at Plaza level forn the trunis of "tree" assemblies, generally branching out to become three coiusns above fioor 7 . The columns are weioed box sections consisting of four steel piates. The coiuan field spicices are made by bolting the base plate of the upper tiet colum to the cap plate of the colum below. Interior horizontal diaphrag plates stiffen the colum web and Elange places at critical locations. The spandrels are plates typically $13 / 8$ inches thick by 4 feet 4 inches or wore in height, usually replaciag a portion of one of the colum plates. Spancrels are cield-bolted to the spandrels of adjacent panels wich dual splice plates, providing for symmettical (double shear) connections srom pacel to panel.

The cores support the balance of the gravity loading. Above the 7 it sloor the cores do not share in cesisting lateral forces to any sigaificant extent. The core columns in the upper scories are colled wide-flange shapes; as colutan loads accurulate in the lower Eloors the rollted shapes are replacec by built-up box sections. Floor framing within the core consists of rolled steel beams supporting formed concrete slabs or slabs on steel deck. Below the 7 th floor the cores are $x$-braced to carry lateral loads down to the plaza level and below.

Outside of the rectargular core, the lloors span from the exterior wails to the core. In the sypical senat floors, concrece slabs on steel deck are supported by a shallow truss syster. Paized trusses, with the pairs located 6 feet 8 inches from adjacent pairs, are on 60 foot and 36 Eoot spans, wich perpeadicular deck support meabers and cransverse crusses Aterrating at 6 feet 8 inches on center. Ihe overall depth of the trusses/deck/slabs is 33 iaches. The truss webs extend above the deck to provide composite action wich the concrete. The transverse trusses are connected to adjoiniag uniss to provide Ewo-way spanning action, particularly at the building corsezs, contributing 00 a bigh reserve load capacity. The floor trusses are connected to alternate exterior coluans, with a weided connecion at the cruss cop chord, ard a visco-elastic damper at the bottor chord cushioning the wind-engendered vibrations localiy, and contributing to systeg-uide damping. The area outside the core at mechanical floors is frated by rolled steel bears supporting corcrete slabs on steel deck; daxpers are in theit connection to the exterio wall panels. 
It both tovers the space frane Eron Floor 10 to the penthouse Root is farmed by the addition of structural steel diagonals along the core colum lines ia the orthogonal directions to create with the columas and bears a network of intergecting trusses. This system wobilizes the interconnected $s:$ tucture to limit di fiferential remperature dispacerrents, and serves atso as a foundation for the TV tast atop WTC 1 (provisions for a similar towet, or four stallez cowers, have been incorporated into che stzucture for hic $2 \%$

B. Symetry

Y: is ioportant to realize that clear lines of syametzy exist in much of the tloor franing, particularly that of the prefabricated floor components, and that Towers 1 and 2 share core or less identical floor framing. in this work, then, considerable reperition exiscs. It is even more important to realize that like levels of symetzy do not exist in the prefabricated pall panels of the exterior cube:

- There is no syametry about the building center line for any one face of any one building.

- No two faces aze the same.

- The two cowers are not the same.

This Eollows because the individual rowers ate not destgred as stand-alone buildings. That is, full advantage is taken of the wind shideling that each cower gives to the other. Also, there is no symety in the juxtaposition of the plan location of the two tovers and aerodynamic loading and responses vary with winds from each point of the carapass.

C. Redundancy

A very considerable level of redundancy exists in the lateral force systems of the twin towers. This redundancy stems frore the structural interaction of the Vierendeel tubular wall and from the staggering of the splices of indivicual wall panels. It is possible, then, to invalidate hundreds, perhaps thousands of individual connections in the tubulat walis, while still cartying full gravity load and more common leveis of wind loading. This redurdancy hes unnecessary the need to ascertain that specictc contactions ay bave been subjecsed to stzuctural degradation... and one need turn one's concern to the larger issue of the possible systeratic degradation of systems, as opposed to components.

The prefaoricated floor system, also, carries considerable recuadancy on account of the two-way usture of every part of this syster. 
Core framing carties a level of redundancy associated with the bending sigidicy of so-calied "situple" connections. This zedundancy, while not easily amenable co calculation, is of the same order as is found in conveational steel buildings.

D. Dampers

As part of the development of structurbl systems for the cuid towers a desize to improve the damping characteristics of these systems was both recogaized and satisfied. A new dampiag system was developed by LERA, waking use of viscoelastic waterials manufactured by $3 \mathrm{M}$ compan. This product, later incorporated into columbia center (seattie) and now planced for incorporation inte several other buildings, is designed to reduce the swaying motion of the towers. The daxping systems are not reeded for structural integrity, but rather to reduce the perception of s:ructure motion by buildigg cenants. Individual damers are not signifieant to damping perfornance as it is the sumation of all dampers that contributes to the whole. sccordingly, the integrity of any one daxper, or even of several hundred daxpers, is not essential to the dyamic performance of the rowers.

E. Sha $\{ \pm$ wa 11

While strictly speaking not a part of the structural syster, the fire-resis:ive partition system used in the service core was developed by IERA uith the goals of reducing the weight, the initial cost and the matintenance costs of these partitions. While these goals were realized, and wile this system (now ealled shaftwall) has found its way into nearly everg new high-rise building, the lizination or masony partitions results in a loss in building stiffness, structure damping and building densicy ... all of which lead to increased dymamic response usder wind excicacion. These losses are offset by the viscoelastic damping system described in the previous paragraph. 


\section{INSPECTYON PROGRM}

A. Visuai laspections

Since the concurrent visual inspection of the entire structure or even a major portion of it is noe a practical goal, a statistical approach is follcwed. Itis approach isvolves the sampling of those components and systems which are more inportant to structural integrity, and at locations wh a relatively higher pocential for occurrence of detects or problens.

Within the bounds of the suggested sampling procedure, the inspection frequency and the building layour, it is anticipated that the in pection work can be arganized ta proceed in a nore or less lineat sequence to minimize both waste motion and duplication of effort, and to help insure that no itaportant itera is wissed. The inspection tean whould carry a get of reduced drawings, individusl field notebooks, a camera and rape recorder. Equiprent, clothing, wethods and procedures should conform strictly to the Port Authoricy's safecy regulations; Federal, state or local regutations may we: I govera some aspects of this work and should be respected.

Visual inspection should be supplewented by the use ot simple hand cools, measuremerts, and recording cechniques as needed. Whece structural steel members or connections are covered by spray-on Eireproofing, concrete or tasonry encaserent, zemove loose, cracked or cust-3tained cover therial co exarine the steel.

Where the location of an observed defect is difful: to describe accurately, the affected nember can be field-marked with crayon to assist in locating it at a later date. When the nature or the location of the observed defect cannot be described simply, field sketches with messurements or $3 " x 3^{\prime \prime}$ cr larger clear color photographs should be wade, and captioned at the site.

Where the inspection procedure involves the removal of apray-on, concrete, or block tireproofing from even a part of atsuctural steel nember, or there it requiteg the removat of a portion of ceiling, the material removed should be properly replaced on completion of the inspection. It should be noted also that gome assestosmased fireproofing materials are known to be within the buildings and that special care need be taken in the removal and the handing of such materiais. Where it is necessury ro drill a hole through an element of a structutal steel member to provide access for a borescope or other device, the hole siameter should be selected to provide the rinimum ciearance requirte; upon completion of the inspection, the access hole should be well sealed with weld metal, body putty, or caulking as appropriate. Whece it is specified that exterior Einishes such as colum covers are to be removed, the material exposed should be provided procection from the weather until the permanent cover is rescorad. 
Where sigas of water leaks suggest the probability that water has entered a box colum, use a bozescope to examine che incernal surtacts of the colum at base, cap, or diaphragn plates ar che levels imediarely below.

1. Periodic Inspections (Remarks apply to both cowers uniess noted specificaliy sor only one)

a. For the structural incegricy inspection prograw for the tv antenna rast on top of WTC 1 , see Appendix A. Make certain that noce of the antennas on the ast wil be operating during the inspection and repair procedures and that orber proper and gtatutory safety precautions ar taken.

b. Every year, examine all exterior root and wall elements for signs of watez intrusion. Roof leakage should be ascertained from 2 careful exaination of the spaces immediately below the rool areas. Wall leakage should be ceterrined from signs of water staining of interior finishes.

c. Evezy year, conduct an inspection of zoom occupascies and uses throughour WIC 1 and WIC 2, to verify that the design ive load is not exceeded is any space. For reference in this survey, a schedule of allowabie live loads must be maintained and up-dated as stzuctural modifications are made; no such schedule now exists.

d. Every second year, examine all accessible colum envelopes or fireprooking for sigas of zust or cracking, bowing, or devistion from plumb. At colums in elevator shaf:s, where the colum is braced directly on only one axis by connecting beams or abutting concrete slabs due co large bean offser dimensions, inspect for laters l displacemen: or rotation of the colum about a vertical axis (refer to Appendix C, Table I). At Sub-level 5, examine the slabs on ground surrounding each colum for signs of rast or deformation.

c. Every second year, examine the fireproofing envelopes or masonry partitions enclosing the diagonal bracing on the exterior column ines in both covers below Service Level Floor (Elevation $\left.294^{\circ}-0^{\prime \prime}\right)$, and the transfer trusses below Flooz 1 in WTC 2 under exterior and core column (refer to "Exterior Wall to Floor 9 Elevations," Appendix C, Drawings i25 through 128, prefixed SA for wTC 1, SB for WTC 2). Inspect for cracking, stains, and other possible sigos of stzuctural distress.

1. Every second year, inspect the bracing truss aembers berween Floot 107 and the roof in the core area (zefer to "IV Mast Support Elevations, "Appendix C, Drawings 401 through 406, prefixed Si for WTC 1, SB Eor 'NTC 2). 
g. For the locations of the colum and spandrel intersections and "tree" junctions described below, refer to "Exterior wall to Floor 9 Elevations," Appendix C, Drawings 125 Inrough 128, prefixed SA for WTC 1 , SB for WTC 2 .

Every fourth year, inspect four exterior box colums which center under "tzees" (two each at wTC I and at WTC 2) below Floor 7 at levels described below. Unless otherwise noced, exterior alurinum colum covers and spray-on Fireproofing are to be removed to gain access to the exterior surface of the colum and spandrel plates specified. In each instance, visually examine the steel coluan or spandrel plate for bowing or distortion, eracking, and corroston. Vistualy inspect all accesaible welds, and use wltrasonic testing to exanine full or partial penetrazion velds and adjacent base meral where base metal thicknesses exceed $1 / 1 / 2$ inches.

Drill an access hole in column or spandrel place, located on the colum center line at the approximate levels noted belos, for use of a suitable borescope to examine the colum box interior for the presence of water and the interior plate surface all around for rust.

Inspect the intersection of colum and spantrel panel at Elevation 350'-3", and also at Floo 2 , with access for the borescope at aid-hestht of the spandrel. For those column-spandrel junctions at Flooz 2 which are below exterior Plaza level framing, a temporary opening cut through the plaster celling below Floor 2 outboard of the colum is needed for access.

Inspect the "rree" junction, where three superstructure colums merge. Examine the top surface of the horizontal diaphragra plate that caps the tapeced box just below the poiat at which the three separate colums appear. Inspect the extezior column plate between this point and the columa splice at Elevation $372^{\prime}-4 "$ "

h. Every fourth year, inspect steel floor framing over mechanical spaces and other areas without suspended cellings.

2. Every Eourth year, inspect concrete slabs, partitions, aad finishes for signs of distress which ongtis indicate excessive seructural deformation. 
2. Occasional Inspections, Monitoring of Reports

When general repaizs or cenant remodeling involve removing ceilings, partitions, Ėnishes or other cover, a thorough inspection should be a ade of the steel framing and connections and the conctece while they are exposed to view or under fireproofing. In particular where carpeting or other floor finish is removed or shows evidence of displacement, examine the slab cop surface for cracking, spalling, and exposed or corroded cop reinforcement.

Repais Eloor areas there rebars are corroded and slabs spalled near trench headers, as tenant relocation perrics or on a prioricy basis where warranted.

Vse collected general maintenance reports and tenant complaints to search for symptoms pointing to underlyiag structural defects. Water damage caused by leaks at roof or exterior wall, broken plubing, partition or floor cracking should be reviewed to desermine whether the problem is confined co the non-structural eiement itwolved, or is part of a patern resulting from structura? deformations. Tenant complaints of building sway, floor vibration, sagging ceilings, unusual noise, and the like, should be recorded in logs for each tower. Where teasonable assessinent of the data in reports or $l 089$ can be tied to a specific structural element or systed, it should be followed promptly by visual inspection of the suspect area. In addition, report and log data should be corralaced with testing and measurements wade under Section $B$.

B. Periodic Messurements

Periodic measurements of building sway and vibration characteristics, plumbress and floor level are rade for the purpose of monitoring changes in these indices, which could point ro a change either of loading, or of stiffness, the latter reflecting possibie structural deterioration.

1. Nacural Frequencies - Towers

Install acceleroreters on Mechanical Floor 75 in WTC 2; one at each exterior wall near its widpoint, oriented to respond to horizontal displacements pars?lel to the wall, and two near the georetric center of the \$loot co respond to displacerents along the $N / S$ and $E / W$ central axes of the building respectively (reter to Appendix $C$, Figure ?). The accelerometers are to be connected to suitable aplifiers and recorders. Vsiag chis equiprent, and the instrumentation already in place in NTC 1, natural frequencies are to be weasured and recorded For each tower once a wonth for $N / S$ and E/W translations and for torsional moverents. Wind speed and direcion at the time of measurement are co be recorded also, preferably based on reliable on-sice measurenents. A continuing log of significatit weight changes of the cowers reecs to be maintained, to be used in the evaluation of measured deviations Erox previous Erequency measurements. 
2. Narural Frequencies - Ty Mast

Install acceleroneters and amplifiers within the heaced enclosure of the 350 foot high $N$ ancenna mast on cop of WTC 1 , at a tevel about $2 / 3$ of the height of the xast above its base, to be corrected to recorders within the building. One accelerometer is to be oriented to respond to $\mathrm{N} / \mathrm{S}$ displacerents and nother to E/W displacements. Periods of vibration of the ast in each direction are to be recorded once a wonth, along with wind speed and direction.

3. Natural Frequencies - Floor Construction

Tenant change or remodeling presents an opportunicy to measure the atural frequency of vertical vibration of floor sections at a time when the space has been empied. In the typical floor, the area ourside the core can be divided into zones of 3 cypes; within eact type it can be expected that imilar vertical dynanic characteristics will be found at any cypical tenent tloor. The 4 cortaer zones, each consisting of a bo foot square area ar corne: of the tover floor space constitute one such type. The remaining spaces between cornet zones make up the orher two rypes: cwo long span zones with a 60 toot span, and ivo short span zones with a 36 Foot span. Refer to Appendix C, Figure 2.

In each tower, the Mechanical Equipment Floors 7,44 , and 75 , and the tenant Floors 7, 43, and 77 directly above them are not to be included in the floor frequency measurement program; these floors are framed conventionally with steel bears, and are to be inspected visually.

Also, it should be noted that telephone Equiprent Floors 10 through 13 in wTC 2 , framed with shallow trusses similat to the typical tenant floor constraction but more heavily loaded and stifter, will have different dyamic characteristics Erom correspondinz zones of the typical floors.

a. On each occasion where a zone substantially free of cenant loading is available, the ratural frequency and damping values of the floor structure withia the zone are co be geasured by perforing a "heel drop" cest, in which vibrations induced in the soor structure by a vertical impact are recorded using an accelerometer attached to the floor, and associated equiprent.

b. Locate accelecometers at the same location on each floor, at or near points of maximur statical detiection, with the precise location to be deternined by experimentation.

c. The hecl drop shcula be standardized. While actual values should be decermined by experinentation, 100 pounds dropped approximately $6^{*}$ onco a l" thick neoprene pat should be about the right input level. 
4. Visco-Elasic Dampers

The tesing prog:ad for the visco-elastic dampers should continue, consisting of:

a. Continuous measurement and recording of hTC 1 building movements of 3 ar tore inctes, with concurrert wind speed aad direction, at leas: until the end of 1985 , and longer to the extent that Eunds are available.

5. 12 visco-elastic daming units are to be removed from fic 1 analily asd tested by $3 \mathrm{M}$, using 4 units from each of 3 Eloors, from zones 1, 2, and 3, replsced by daming units from storage. Testing is to include zemperature effects and shear strengtin.

c. A cootinuous log of tenant corplaints on core noise and building sway will be kept.

5. Plumbness and Leve?

Pluboses and level surveys should be timed to coincide with periods of low wind speed and moderate tempersture, as in the early worning tours in August.

a. Make building plumbess and 100 r level checks semi-annually for each rover. Investigate plumbress by measuring the offsets from a vertical laser beam, projected up from the botcon of the shaft, to the shaft walls of Freight Elevator No. 50, at 20 story iatervals, establishing permanent neasurement stations on each vall. Accuracy of the order of $3 / 4$ inch (20 ma) is desired at the top of the shaft, with proportionately greater accuracy at the lower levels.

b. Essablish 16 beach warks on the Eloor slab at Floor 70 of each tower, one at eact corser ard mid-point, adjacent to the exterior wall and adjacent to the core bouncary as defined by the core coluons. Measure the elevation of the remaining bench barks relative to one located near a correr of the core, using an engineer"s level. Accuracy of levels should be to about $1 / 16 \mathrm{cb}$ iact $(1.5 \mathrm{~mm})$. 


\section{INSPECTION PERSONNEL - IN-HOUSE}

A. Inspection supervisor

The Supervisor of the Structural Integity Inspection of the Buildings is unier the ditection of the Engineer of Desiga, intrastructure. The Supervisor is responsible for planning and directing the saspection, and preparing the report. The Supervisor should possess the following mininum qualifications:

1. Licensing

professional Engineering licens in vew York or New Jersey specializing in 5tructural Engineering.

2. Experience

Five years experience in responsible charge fin structural design of buidings and five years experience is responsible charge in one or tore of the following atrivities:

a. inspection of butlding construction,

b. inspection of existing buildings, and

c. maintenance of buildiag structures.

The supervisor does not have to conduct the actual inspection, nor does the Supervisor have to be present at the site at all times when isvestigations are in progress. The Supervisor is expected, rather, to be familiar with the entite scope of the grogran, to provide leadership and guicance, and to be in close touch with all of the on-going activities in the various sub-prograns.

He is responsible aiso for setting up and for supervistng such training as is requized for the ream members.

B. Leader Qualificacions

The leaders of each of the crews comprising the Inspection Iear shall have, in addition so the genesal qualifications listed below for teat members, three years experience in responsible charge in one or wore of the following activities:
a. inspecion of butiding construction,
b. inspection of existing buidings, and
c. maintenance of buildiag structures. 
c. Inspector Qualificacions

The Eleld isspection crew members should be adequately qualified so as to be capable, after receiving noderate guibance on the initial run, of operating the prograd without detailed supervision. The most important qualizicakions for a field inspector are acuse observation skilis, comon sense, strong notivation and persistence in carryiag out any necessary follow-up procedures. The inspectors should be prepared to Eind serious defects rather than co assume that no problens exist. where situations beyond the iaspector's area of corpetence are encourtered, guidance by supervisors should be sought.

As 3 minimum, the inspector should:

- be able to climb steel and function comfortably at great heights and in difficult posicions;

- be a high school graduate or equivalent, wich cormensurate reading, verbal and vritten communication skills;

- read and understand constuction dravings and other documents;

- lecter legibly and be able to sketch technical details;

- be able to operate a camera;

- have a working knowledge of the use of measuring devices, such as rslers, capes, gages, protraciors and callpers; and

- exhibi: a proper concern sor safety while inspecting.

It is also desizable, but not mandacory, that the inspector have sone prior experience in related work, such as high steel construction, structural aincenance or iospection, or surveying. 


\section{OUTSIDE CONSUL ZANTS AND SUPPLIERS OF SPECIAL SERVICES}

The consulting fira engaged to carry out periodic visual inspections, or to accomplish tasts requiring spectal skills and use of specialized equipoent should assign a Supervisor who is a professional engineer licensed in New York or vew Jersey and should have the ability to perfom the work as deronstrated by a initum of five years experience in the design and the tieid supervision of protects of comparable size and complexity. the personnel assigned to the project should possess, as a winimu, qualifictions equal to those listed in "Iaspection Personal - In-house."

Before sebection, the consultant should submit co pasyos a listing and description of comparable projects completed, and a ist of the people to be assigned to the project with a resume of experience and ozhez qualifications for each. 


\section{RECORD-KEEPING AND FOLLOW-UE PROCEDURE}

The defests and signs of distress listed below are to be noted and recorded uherever encountered in elements salliag inco these caregories.

A. Structural Steel Defects and Signs of Distress

1. Rus =

Classigy as "light", a !ight, loose Eorration pitting the paint surface, "moderace" a loosef Eorartion with scales or flakes forming, or "severe" heavy, stratified rust or scale with pitting of the metal surface. Heasure net metal thickness and size of penetrations, if any, where pitting has occurzed.

2. Cracks

Classify as "fine", "mediutu", or "open." Note length, size and location. any crack is potentialiy very serious and should be reporsed imediacely.

3. Buckles and Rinks

Note the type, location, extent and asount of deformation.

4. Connection and Joint Defects

Note fise cracks ia the paint at jolnts as an indication of large strains due to stress concentrations. Note sheared, aissing, deformed or loose bolts, and evidence of slippage between condection plies. Note gisser plate defortations norma to the face of the plate where an intersecting rember connects to the face. Note cracks in welds or adjacent base metal.

5. Alignment, Excessive Deflection or Bowing

Sight along truss or space frame elements, bearas or colunns to detect misalignment, deflection or bowing, Record the deviation frow true line, pluab, or level.

6. paint

Examine for cracking, chipping, rust pitting and chalking. 
3. Reinforced Concrete Defects and Signs of Distress

For definitions of the defects and classificarions as to degree of severity, see Rererencel.

1. Scaling

classify as lighr, pediun, heavy or severe. Note the depth, extent and locations.

2. Cracking

Classify by type (partial or through the merber; dizection relative to framag or colum liaes; horizontal, vertical or Aiagonal; D-, map, or randon cracks). Note the location, width, depth, and length.

3. Spalling

Classify as sratl, Iarge, hollow atea, joint spall, pop-out, or mudbalh. Note the depth, size or extent, and location.

c. Inspection Records

1. Identifization

Each corponent should be identified as to geners location (building number, fhoor or floors), description label (colum, beam, floot rruss, visco-elastic damper, siab, etc.), piece mark and colum designations at each end as applicable, and the rype and location of the affected part. For example:

PTC 1 - Column 70, Floor 78 to Floor 79 , east side of north Elange.

- Flocr 66, Floot panel Fl (NE), Floor truag C32Tll, w of Colum 157, consecting welds to zloor truss 24I7A on centet line colum 210 .

- Floor 78 , Beam 3708 connection to beam 3721 , E of Columa 802 .

- Floor 78, slab bounded by center line colums 123, 125, 206 and 208 . 


\section{Description}

Describe the defect or indication of distress. provide messurements, sketches, or photographs in those instances where the witten description can't adequately define the location or problem. Further comment can be entered on a :ape cecorder; the $t=s a s c r i b e d$ comentary can be appended to the inspection report. Prinis of the fraring pians or detail drawings or photocopies of relevart portions of then can be marked up whea useful in clatifying location or condition.

3. Special Reports

All defects or indications of distress that appeat to the Supervisor or to the inspection team to require fore than routine attention should be included in a separate report to the Engiceer of Design, Iofrastructure. For conditions of a serious nature, stect notification should be made imediately in person. Repairs of a routine nature can be recomended by the inspector.

4. Trgeacy

For each reconmended repair, or condition requizing repaiz, the relative urgency of the action to be taken is to be categorized as "Imrediate," "Priority," "Routine" or "Non-Priority":

a. Immediate - Action inclules possible closure of the area and/or structure affected, until interim remedial measures, such as shoring or rewovsl of a potentially unsafe element (or structure) can be implemented. These items would have beea acted upon imediatel whea discovered, but a description of the actions taken and recomendations for permanent repairs should be inciuded in the sext of the inspection report.

b. Priority - This is for those conditions for whach no insediate action way be required, or for which ingediate action has been completed, but for which furthe: investigation, cesign and implementation of interim or long tert repairs should be undertaken on a priority basis; i.e. caking precedence over all other scheduled work.

6. Rouline or Non-prioricy - Further iavessigat:on and/or remedial work can be undertaken as part of a scheduied major work progra or other scheduled project, or routine facility alintenance depending on the ackion required. 
D. Measurenents and Test Records

1. Reriods of Vibration, Towers and Mast

Towet vibration and on-site wind speed and direction measurements are being logged each nonth sor each rower. The periods of vibearioa for $N / S$ and E/W translations and for torsional rovenents should be deternined for each tower and for the ryst. Showld compatison of the vibration pertods with previously cecorded data for towers or ast reveal a statistically significant deviation, the relevant data need be calied to the imaediat atention of the Engineer of Design, incastracture.

2. Foor systers

The floor vibration measurements resulting from the "heel drop" tests should be compared with prior measurements for sivilat Eloor structure zones, where avaiable. In the event that the srequency of the damping ratio deviates frow previously recorded values, data need be forwarded imediacely co the Engineer of Desiga, Infrastructure.

3. Additional Data

In conjunction with the floor truss visco-elastic damper testiag carcied out by $3 \mathrm{M}$, records of WC 1 bullding movements of 3 or more inches with correspondisg wind speed and dizecion xeasutements will be kept at least until the end of 1985 . In acdition, iogs of tenant corplaints on core noise, building sway, and the like will continue to be kept, listing date, cenanz's location, and nature of complaint.

4. Plumbings and level

Data obtained from the sexi-annual plumo and level surveys are to be compared to prevtous records to monitor possible building lean or floor till. 
इ. Periods of vibration

Since $a$ zeduction in stiffnes of a structural system is symptomatic of deterioration or damage, vibration period reasurements aze used to monitor stiffness. To interpret tie significance of geasured chanes in vibration period of the system, it is necessary to take isto account changes in weight of the syster, for which purpose an initial tabulation of weight wust be wade, and a log of weight changes kep:. To facilitate evalustion of future asurements, the initially measured v\$lue of the period $t$, in seconds, can be plotted against the syster weight $w$ at the corresponding time, using the relationship $k=\mathrm{CH} / \mathrm{T}^{2}$, and sssuring any convenien: value, such as 1 or 100 , for the sitifness $k$ and unity for $C$. Then, for any future reading for I greater than the value of I predicted by the chart for the tabulated system weight at trat time, the percentage reduction in stiffness required to reconcile the two values can be calculated frow the equation above.

1. Excezior walls

Where the calsulated reduction in stiffress is on the order of 5:, acd where any discontinuity is found it $k$, an iavestigation into the possible causes is necessary. In the case of cover vibration period, this would indicate a possible probter in the exterior walls and an inspection of column/spandrel intersections in these walls would be the starting point.

2. Floor Systems

An appazeot reduction in seiffness of one of the typical floor zones calls for inspection of the truss and bracing joint connectiors. Should the damping ratio obtained fror a hee? drop cest for a typical floor zone be less than the initially measured value for a corresponding zone by 10 or ore. deterioration of the visco-elastic dapers at the truss love: chord connections to the columns is a possibility. 


\section{VIIID EXCLUDED WORK}

This standard is focused on structural steel and on reinforced concrete.

The following components are outside the scope of this standard and have been exciuded:

Glass slazing

Facade Panels

Ceilings

Partitions

Elevarors

stairs

High-pressure stest equipment

High-yoltage electrical equipment

ecc. 


\section{REFERENCES}

1. Infrastzucture Design Division, Engineeriag Depaztoent, PANYN3: "Staadards for In-cepth Structural Integrity Inspection of Builjings," Port Authority of New York and New Jersey, October 1984.

2. U.S. Department of Transportation: "Bridge Inspector's Training Manual $70, "$ U.S. Governwent Panting office, $\$ 970$.

3. AASkTO: "Yanual for Maintenance Isspection of Bridges," Amerien Association of State Highway and Transporsation Officials, 1983.

4. AWS: "Welding Handbook," Volume 1, Seveath Edition, American welding Saciety, 1976.

5. Research and Developwent Division, Engineering Departaent, PANYNJ: "Measurement of the Dynaric Response of WTC Tower 'A' Vnder Wind hoads," Report No. 79-5, May 1979. Report No. 81-7, June 1981.

6. "Investigation of Aging Effects, WorId Irade Center Darpers," Robertson, Fowler s Associates P.C., October 1, 1984.

7. "Viscoelastic Damping Units," Report No. Ju-1, Skilking Helle Christiansen Robertson, July $17,1967$. 
APPENDIX A

SIRUCTUKAL INTEGRITY PROGRAY

TELEVISION ANTENA MAST

\section{INTRODUCTIO:}

A. Hiscory

As of this writing, the 350 foot tall television antenna mast on top of ONE WORED TRADE CENTER is approximately $51 / 2$ years old. Erection of the antenal was compleced in Noverber, 1979 atactivation of the First commercial broadcasting in June, 1980.

Maintenance work and interim ingpections, to dace, haye betn performed primsily by tejevision station personael mantaining broadcast antenna units and PANYNJ taintenance personnel furnished under contract by Broadway Haincenance Corporstion.

B. Scope of Progian

This document is prepared to assist in the specifying of visual and con-destructive zesting of the antenna with the goais of providing reasonable assurance to PANNJ that the antena is performing safely as a structure, as well as to assist in identifying preventive maintenance with should be perforsed at a scheduled basis.

This prograw consists of feur sections:

1. Structural Sreel Ancena Elements

2. Wigh Tensile Bolts and Studs

3. Weatherprocf Enclosure

4. Radornes

Structural integrity inspections should be performed on a continuing asis, as weather and operaticnal restzictions perait. Every effor: should be rade to pertorm a complete review of the rast structure within the weatherproof enclosure each year; the balance of the prograr should be done at least once every three years.

C. Additional work

heraiting tor development and appending to this progran are record keeping docunents and integrity review procedures such as specitic ul:rasonic testing procedures, sampiag locations and sapling percentages. Integrity inspections should be documented by diagrams, skezches and photos to the maxiaum extent practicable in order to amplify the tritten description of each integécy inspection. 
D. Safety

Both integrity inspection personal and talntenance persounel should verify that good housekeeping practices are fully in effect in order to =ininize or elidinate conditions conducive to fire hazards, falling, eiectrocusion and the like. 


\section{STRUCTURAL STEEL ANTENAA ELEXENTS}

A. Visual Inspection for Corrosion

Inspect each of the 18 tower sections, the tapered section and the channe? $4 / 5$ pole for sreedon frow corrosion. Use high intensity portable itgth source to assist viewing of structure.

1. Verify freedon from corrosion of all structural parts by visual inspection.

2. Record all locations where paiat failure or corrosion are observed.

3. Record 2ll locations, and extent of each such location, where structural parts cannot be dícecly viewed due to obstructions such as radore, conduit, antenna elements, weatherprook enclosure elements, lack of access, or other condition. Describe condizions preventing visual evaluation of each obstructed location.

4. To the extent possible, view portions of ancenna obstructed from direct visual observation by use of appropriate fiber-optic viewing devices.

5. View those portions of antenna structure not accessible for clear viewing fron within by direct access to the outside surfaces by appropriate ans $s u c h$ as access by boatsuain's chatr.

B. Visual Inspection for Soundness of Base Keta: and teids

Inspect each section, the tapered section, and the channel $4 / 5$ pole for sound base metal and sound weids.

1. Simultaneous with visuat inspection for corrogion, ver fy freedom of all visible surfaces of base metal and of welds frow cracks or other unacceptable discontinuties such ss extessive pitting fron corrosion, defects at weld ends, especially at access holes, chamers and the like. Record all findings, even where apparently insignificant, for comperision with future observations.

c. Uirrasanic Inspection for Soundress of Base Yetal

Inspect each section, the tapered section, and the channel $4 / 5$ pole for suund base meta? and sound weids.

1. Test solid round antenn mast vertisal membes by intensity wethod (sending and receiving c-ansducers) and pulse transit time taethod (pulse-echo method) to assure freedom fror cracking, especially is vicinity of structura: welds and welds for mounting antennas and related parts. Franducer surfaces should be curved to fit the surface curvature of the part tested. 
2. Iest pipe members using pulse transit time method (pulse-echo method) with cransverse sound waves to assure freedom of base netal tow cracking or other discontinuties, especially in vicinicy of seructural weids and of welds for mounting antenras and zelated parts.

3. Test plate steel and rolled steel shapes with transverse or longitudinal waves, as approptiate, in locations as appropriate.

4. Locations of eesting shouid be selected initially on the basis of review of Eabrication drawings for the individual ancenna structure sections and structural elements. Adatitional test locations should be selected in response to the results of the complete visual evaluation of the antenna stcuctural steel.

5. UT equipment hould be calibrated in accord with the appropriate AST, ANS and ASYE standards. Additionally, it may be wise to prepare special calibration specimens representative of full size structural elements, so as to determine the best frequency and transducer size and geomezry for providing meaningful and reproducible sest results.

6. Iboroughness of UT examination Eor the bottom 101 feet of antenna structure stould be based on the highest practicable sampling percentage because this length of antenna has been demonstrated more sensitive ro remperature effects on material properties than the antenna sections above (Teledyne Technical Report TR-2315). 3 ased on generated information. it may be possible to justify reduced sampling percentsges for periodic scheduled UT integrity checks after study and evaluation of records of actual test results and observations. Fortunately, this portion of the anterna structure is available for exarination on a sa more continuous basis than the portion of the antenna above Elevation 101 (top of Section $A=-10$ ).

7. Record al: significant ultrasonic indications (even though not of rejectable levell for comparison wirh results of Euture tests in the same location.

D. Water

Inspect all locations in antenna structure to assure that no location can pood or entrap water accumulations. The examination will reguire a preilimary review of each of the antenna structure fabrication drawings followed by visual examination of each pazt of each antenna section/element in the field. 


\section{HIGH TENSILE BOLTS AND STUDS}

A. Corrosion

Inspect each bolt or scud connecting ancenta sections or terbers within atsema sections for fredom from corrosion.

8. Cracks

Inspect each stud accessible and each bolt both large enough and accessible for freedom from cracks, espectaliy at the roor of threads.

C. Scructural Integrity Check items

1. Corrosion

Verify freedon from corrosion of all projecting bolt heads, nuts, washers and thread run-outs. Repott for prompt maintenance (sleaning and paincing) all bolt and stud parts where paint faibure has occurzed or rusting is in progress.

2. Use of Borescope

To the extent possible, view all pottions of bolts and studs at accessibie for difect viewing by use of fiber-optic viawing devices.

3. VItrasonic Testing

U1zrasonically exanine al atuds and those bolts of sufficient size which can be zeached for UT examination using longitudinal wave equipant. By corparison with results frotoppropriace calibration and reference specimens, verify that studs and bolts are free from cracking, especially in threeded and thread run-cut zones.

Longitudinat wave testing probes shruld be selected for size and Exequency on special calibracion specimens representative of at least the threaded leagh olus a few inches of unchreaded rod to establish the izpe of utrasonic response to be expected from the threaded lengths of bolss and studs. 


\title{
IV. WEATHERPROOF ENCLOSURE
}

\begin{abstract}
Purpose of these procedures is to assure maximun corrosion protection of antenna structural and $\$ 3 s t e n$ elenents. Corrosion due to water penettation or dae to excess humidity withan veatherproot enclosure must be prevented. temperature within deatberproof enclosure must be celiably assured to remain above $75^{\circ} \mathrm{f}\left(30^{\circ} \mathrm{C}\right)$ as recomended ia Teledyne Techrical Report TR-2315.

Detailed revieo should be ade of the temperature raintained within the antenna structute below Elevation 101 (cop of Section AC-10) \$ince the date of instaliation.
\end{abstract}

A. Temperature and Humidity

Maincain accurate records of interior zeraperature and humidicy.

8. Painc

Verify integrty of excerior painting system.

C. Seals

verify incegricy of exterior sealing systens against wat penetration.

D. Heatherprooking System Iategrity Check Items

1. Jetzils around ourrigger supports extendiag from taperec antertia base section to support microdish plat forms.

2. Continuity and soundness of zatertight seal welas for closure (cap) plates on cop of $A C-1, A C-7$ and $A C-10$ and around sleeves penerrating closure plates.

3. Continuity and soundness of exterior cauking system (Dymeric by iremes).

4. Soundness and concincity of seal relds and gaskets at joints in veatherproof closure steel vall plates, steel boots and frot boocs.

5. Protection Erom (and freedom from) rust for bolks, auts, threaded studs, washers, bars and the like connecting sections to adjacent sections or to supports on ancerna.

6. Use drawings TV-1, TV-0, TV1-TV2, T50-TV58, TV111, TV121, TV131, TV141, TV151. W161, T171, T181, W191, and TV192 as guides in performing weathertightress check. 


\section{RADOMES}

A. Connections

1. FRP radorae sections end and edge connections.

2. FRP zadome assembly connections to supporting structure.

B. FRP Shelis

1. Condizion of FRE shells in individual FRP radome secrions.

C. Racone Integrity Check Items:

While the majority of radome incegrity checks involve feacures within the adomes, the bolt heads and Belleville washers are on the outside surface of che radones, the surface from uhich in-place retightening or replacement of radome assembly bolts and tensioning washers nust be acsomplished, if found necessary. Checking of radome connecting bolts will require the use of a botsualn's chait of other teans of access to the outside of the antenna.

1. Examine each radome saction to section connecting bolk and Esna elastic floating stop-nut assembly, bolt by bolt. Stop-nits should be bolding conaecting bolts tight with sufficient tension to provide necessary claming toree in joints and plices between radome sections. Degree of tightness of each floating nut and bolt assenbly should be checked. Corrosion or lack of corrosion of stop-nut assemblies should be decermined.

2. Exanine each radone section for freedom from cracking or other signs of potential distress. Pay special atsention co zones atound bolt holes near ecige, and end lap splises of radone FRP sections.

3. Check condicion of bolts connecting radomes to FRP Extren braces and support arms, as well as bolts cornecting radome supports to structural steel supports. Check condition of Extren apports anc braces. 
APPENDEX $B$

\section{FIBER OPTIC BORESCOPE SUPPLIERS}

Addresses of some Fiber-Optic viewing instruments suppliers are:

Lenox/For:

Lenox Instrument Conpany, Inc.

111 Ease Luray Street

Philadeiphia, PA 19120

Ielephone: (215) $324-4543$

Reicher: Fïber Optics

Warner-Lambert Technologies, Ine.

122 Charlicon street

Southoridge, KA 01550

Felephore: (617) 755-9744

American ACM:

Divison of American Hospital Supply Corporation

300 Stilluater Avenue

P.0. 30x 1971

Scamford, CT 06904

Telephone: (203) 238-8654

(203) $357-8300$

Olympus Corporation

Industrial Fiber Optics Departaent

4 Nevada Drive

Lake Success, wy 11042-1179

Ielephone: $(5: 6) 488-3880$ 
APPENDIX C

IABLE 1: ECCENTRICALLY-BRACED COLUMNS

IN ELEVATOR SHAETS

COEUNN NUMBER

FLOORS

SIMILAR DEIAIL

REMARKS

\begin{tabular}{|c|c|}
\hline $\begin{array}{l}602 \\
603\end{array}$ & $\begin{array}{l}1 \text { to } 33,43 \text { to } 68 \\
32 \text { to } 42,44 \\
\text { E1, } 294\end{array}$ \\
\hline 506 & $\begin{array}{l}17=023,25,26,44, \\
61,62\end{array}$ \\
\hline 607 & $\begin{array}{l}1 \text { to } 17,44 \text { to } 55 \\
\text { E1. } 294\end{array}$ \\
\hline 702 & $\begin{array}{l}1 \text { to } 3 \\
8 \text { to } 33,44=068\end{array}$ \\
\hline 203 & $\begin{array}{l}78 \text { to } 82,94 \text { to } 101 \\
106,107,108\end{array}$ \\
\hline 707 & $\begin{array}{lll}1 & \text { to } \\
8 & 00 & 17,44 \\
\end{array}$ \\
\hline 802 & 785094 \\
\hline 803 & $\begin{array}{l}78 \text { to } 94 \\
95 \text { to } 101\end{array}$ \\
\hline 805 & 78 to 106 \\
\hline 806 & 78 50 87 \\
\hline 902 & $\begin{array}{l}3 \text { to } 8,32 \text { to } 42 \\
43\end{array}$ \\
\hline 907 & $\begin{array}{l}7 \\
1,2\end{array}$ \\
\hline
\end{tabular}

LTC 1 orly

WTC 2 only

wTC 2 only

WTC 2 only

Notes:

1. Refer to paragraph IV. A.l.d.

2. Floor listings guch as "3 to $8^{\text {" }}$ are inclusive.

3. Listings apply to tro 1 and wTC 2 unless noted otherwige.

4. At the Iatermediate Level above Floor 1 and at Floor 8 , inspect

all colums in the elevator shats.

5. Por cypical decal plans A through I, see the following page, 


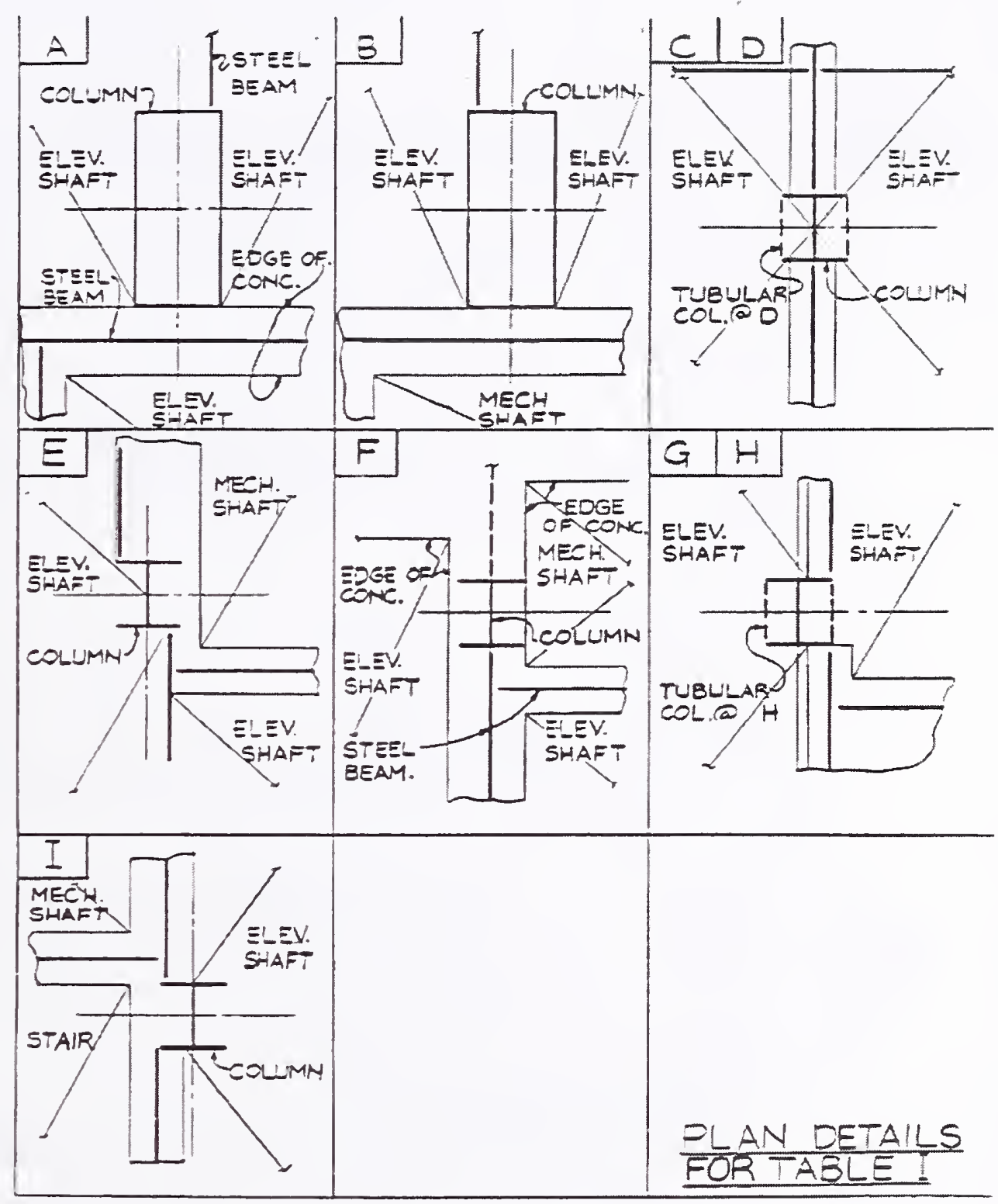

ta:ch 1986

Torld :aade Cencer - Buildings? and 2

Zage $\Xi \vdots$ 


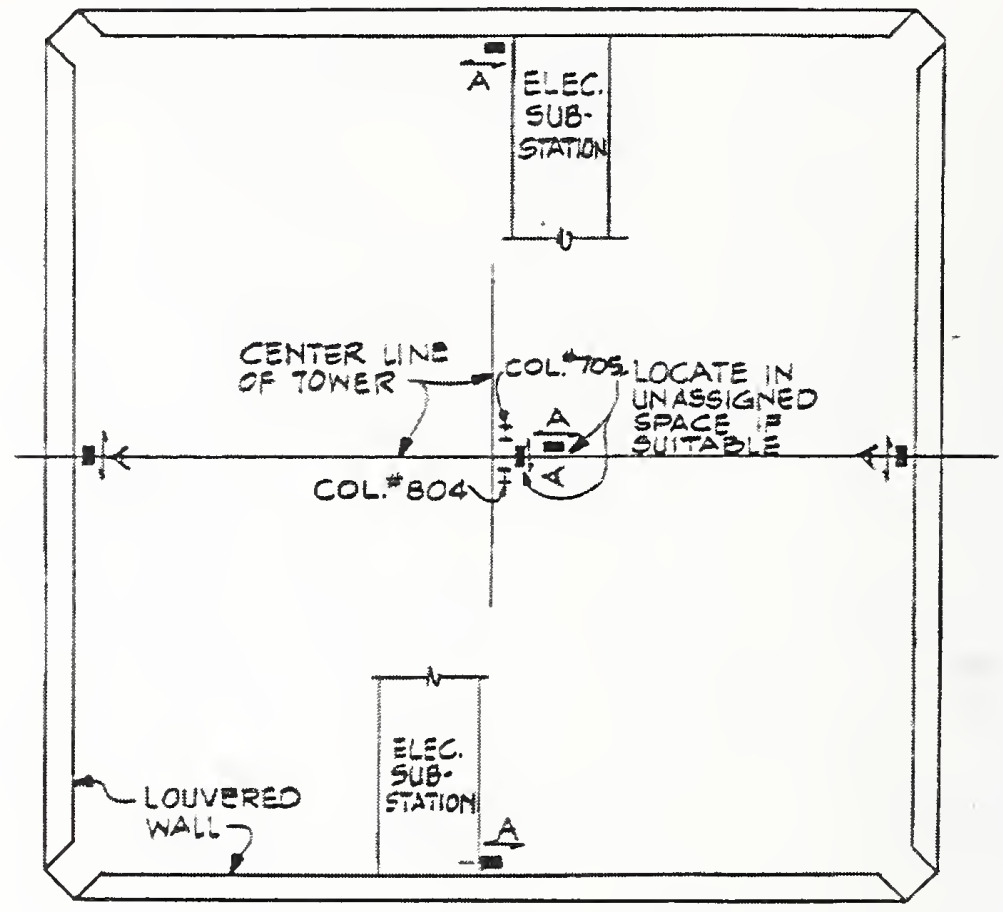

$$
\begin{aligned}
& \text { TE"W } \text { :OOR OLAN } \\
& \text { MECHANICAL EOUPMENT ROOM } \\
& \text { 2WTC }
\end{aligned}
$$

SUGGESTED -CCATIOMS OF ACCELEROMETERS

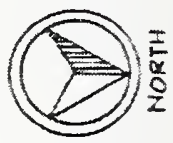

FOR MEASUREMENT OF TOWER NATURAL FREQUENCY

FIGURE :

\section{NOTESI}

1. REFER TO PARAGRAPH I.B.l.

2. SUEGESTEO ACCEIEROMETER LOCATIONS ARE SHOMN THUS: ARROW JESIGNIATS DIRECTICN OF MOIION TO BE RELOROED.

S. VARY THE OCATIONS AO REQUIREO TO CLEAR MECHANICAL EOUIPMETT ANO MAINTAIN dELESS TO THE ACCELEROMETERS. 


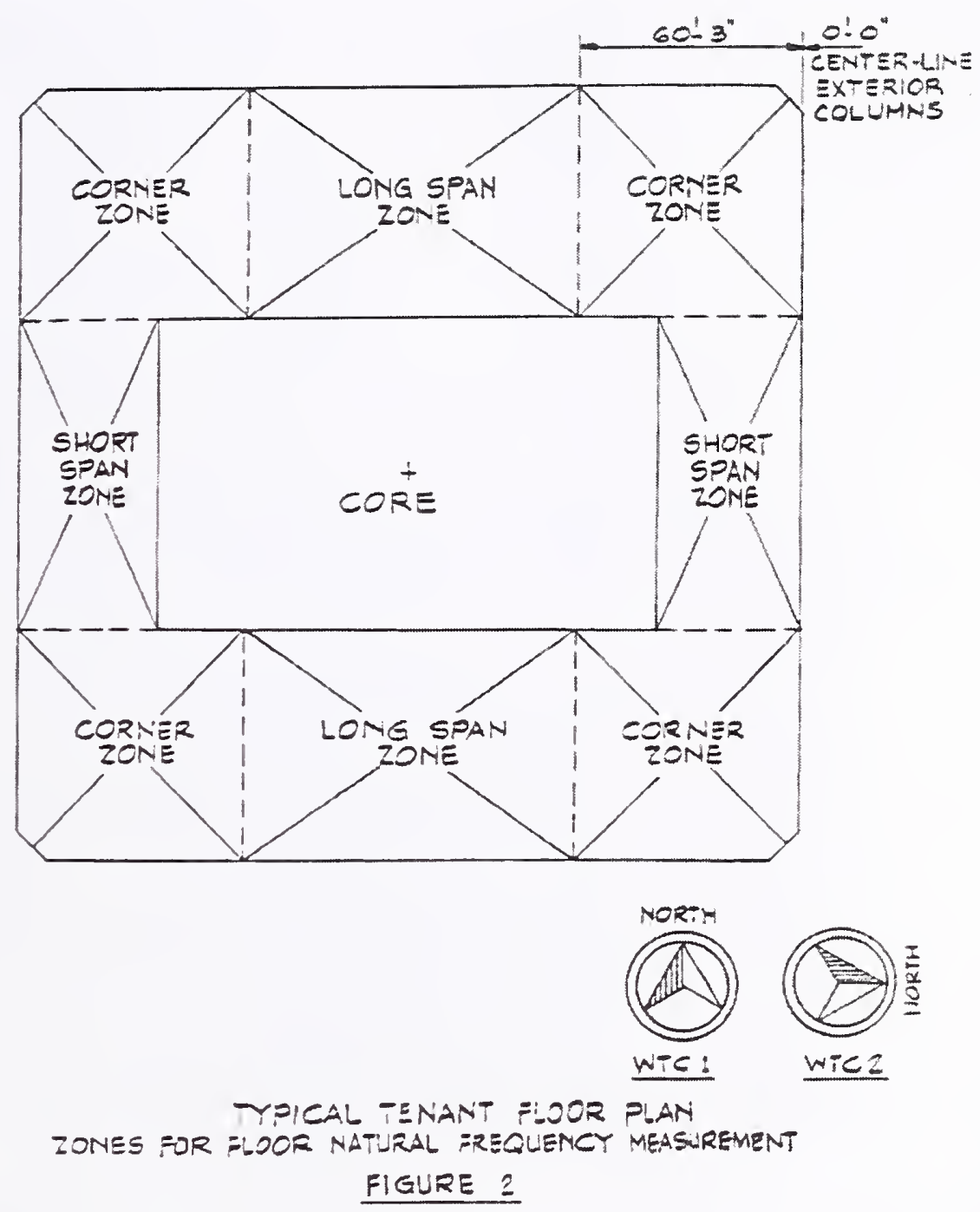

NOTE: REFER TO PARAGRAPH Z.3.3.

بa:ca :986 


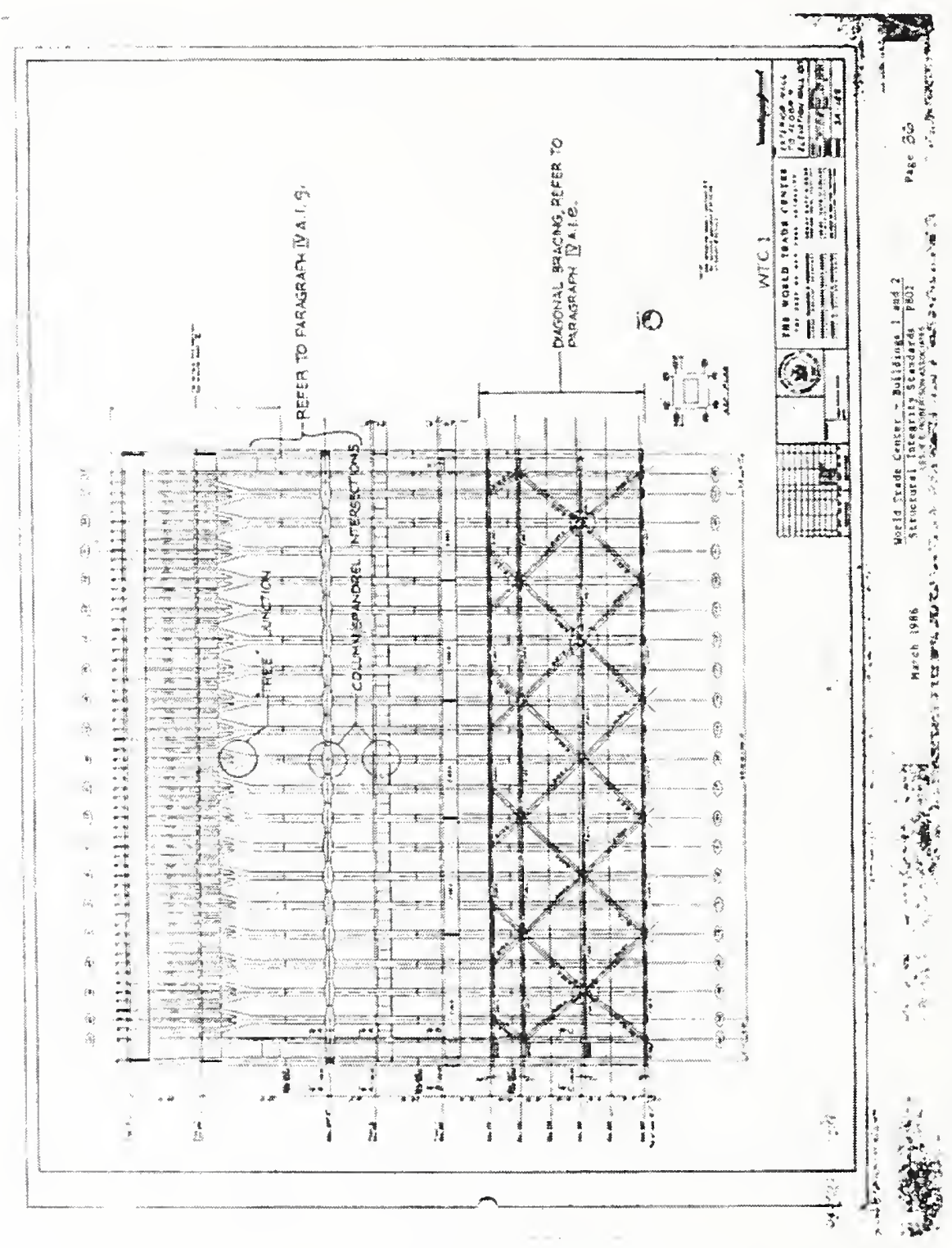




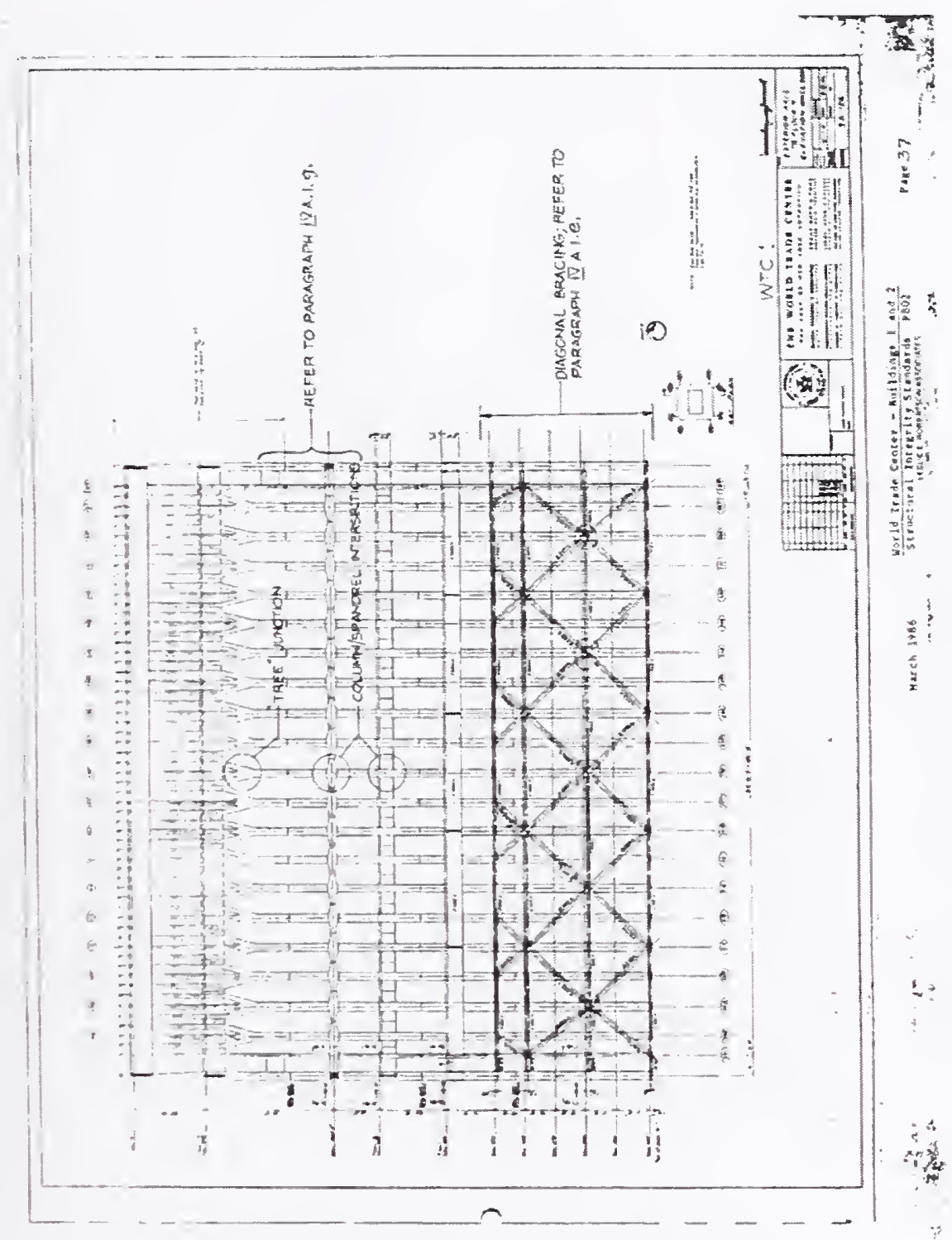




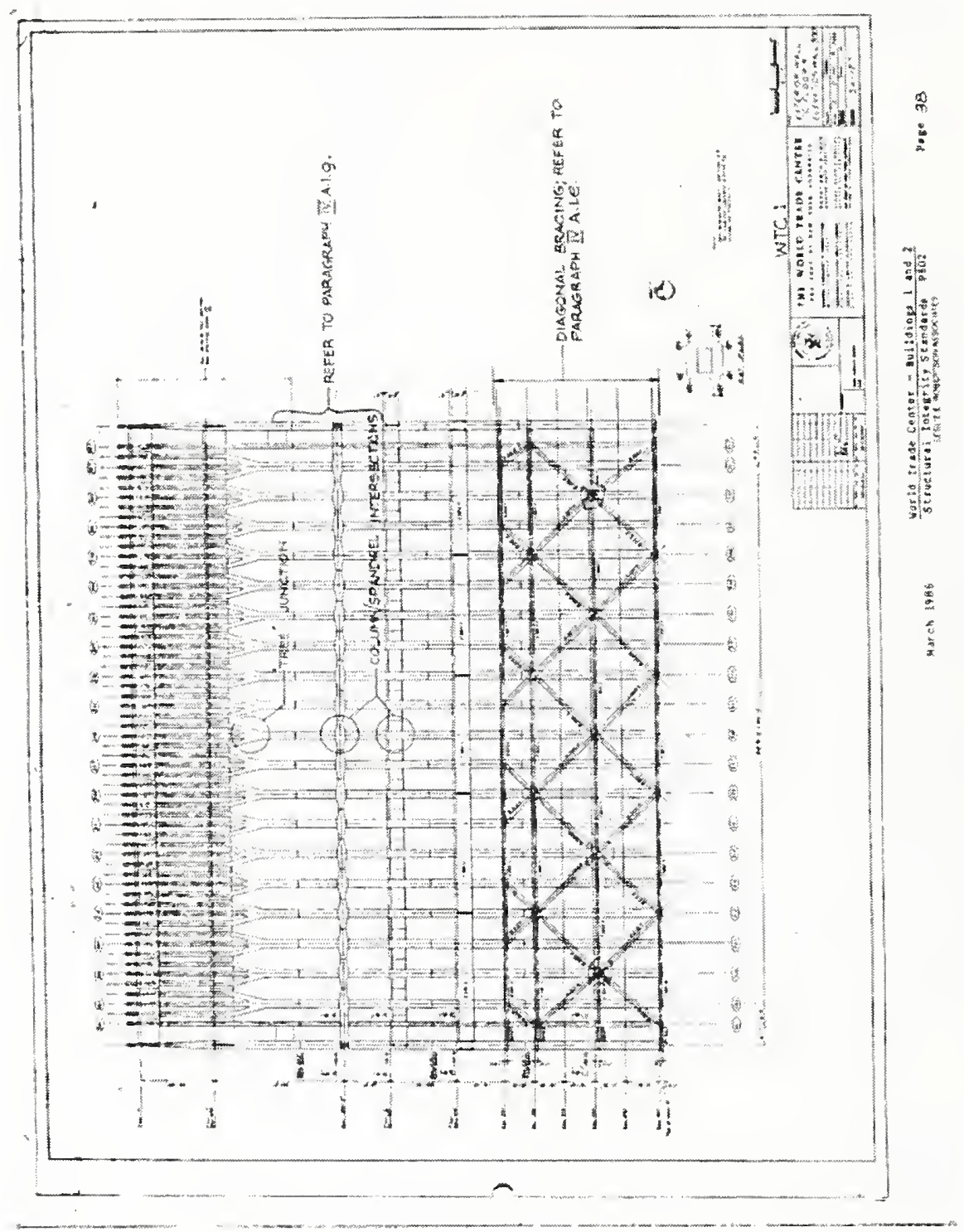




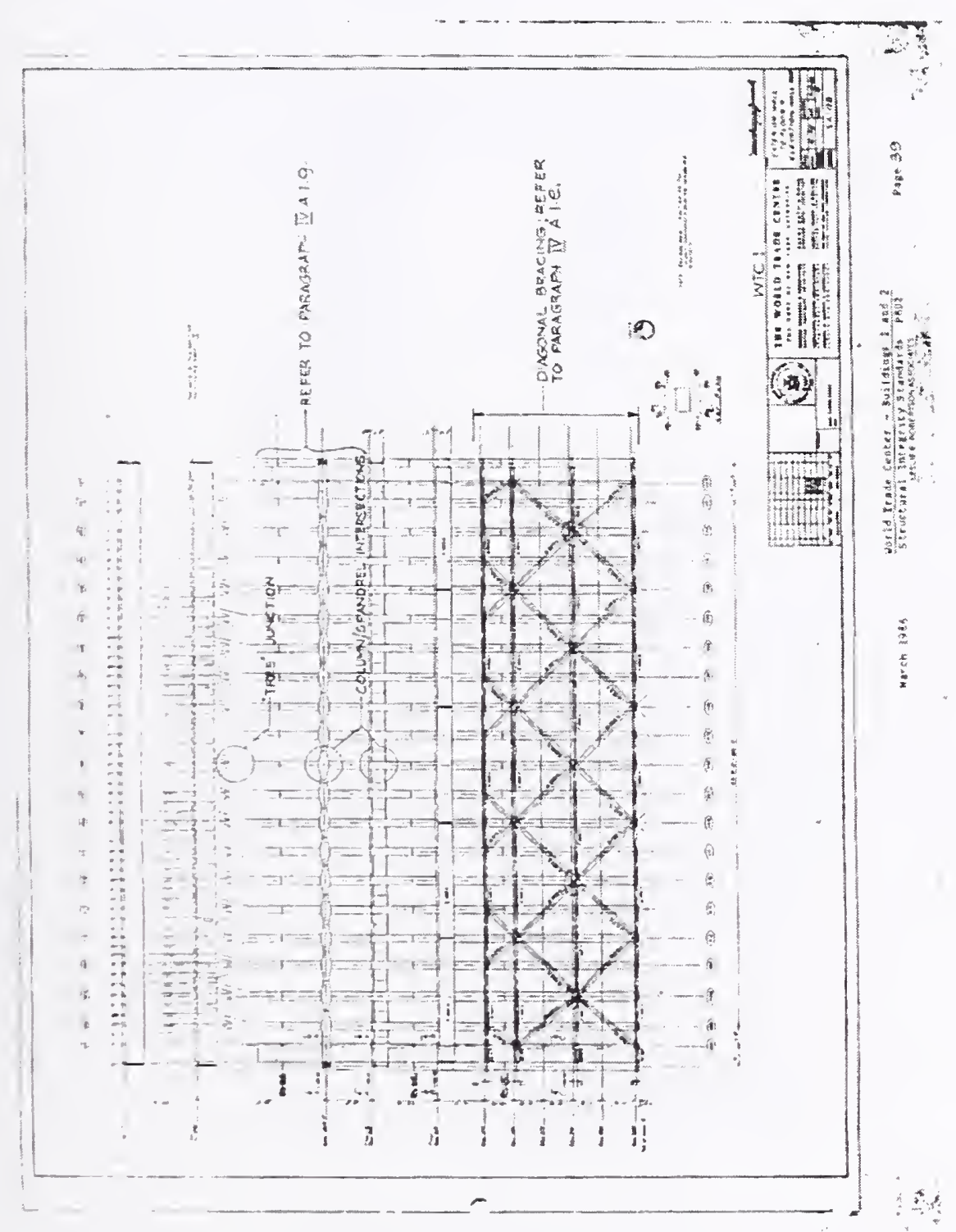




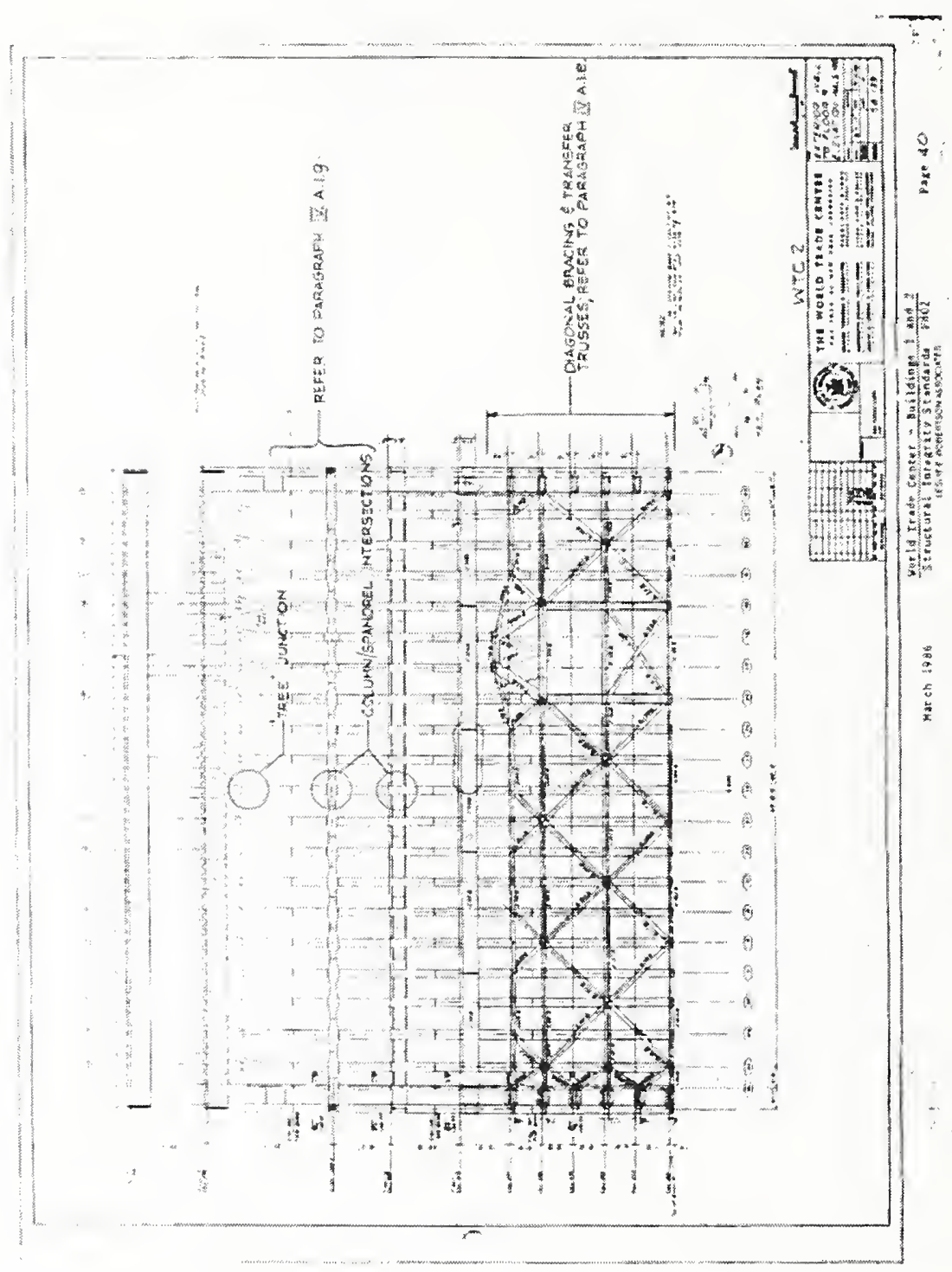




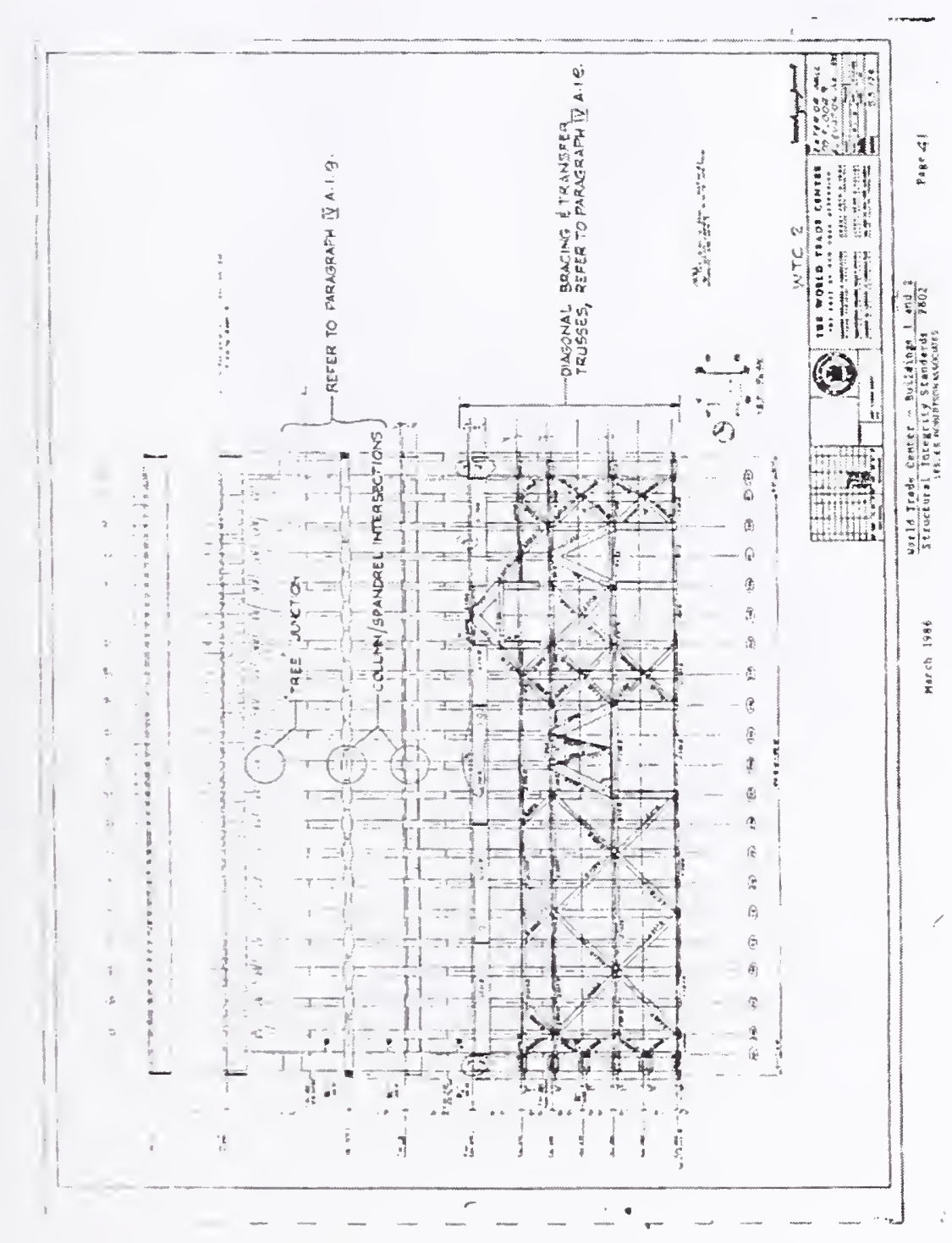




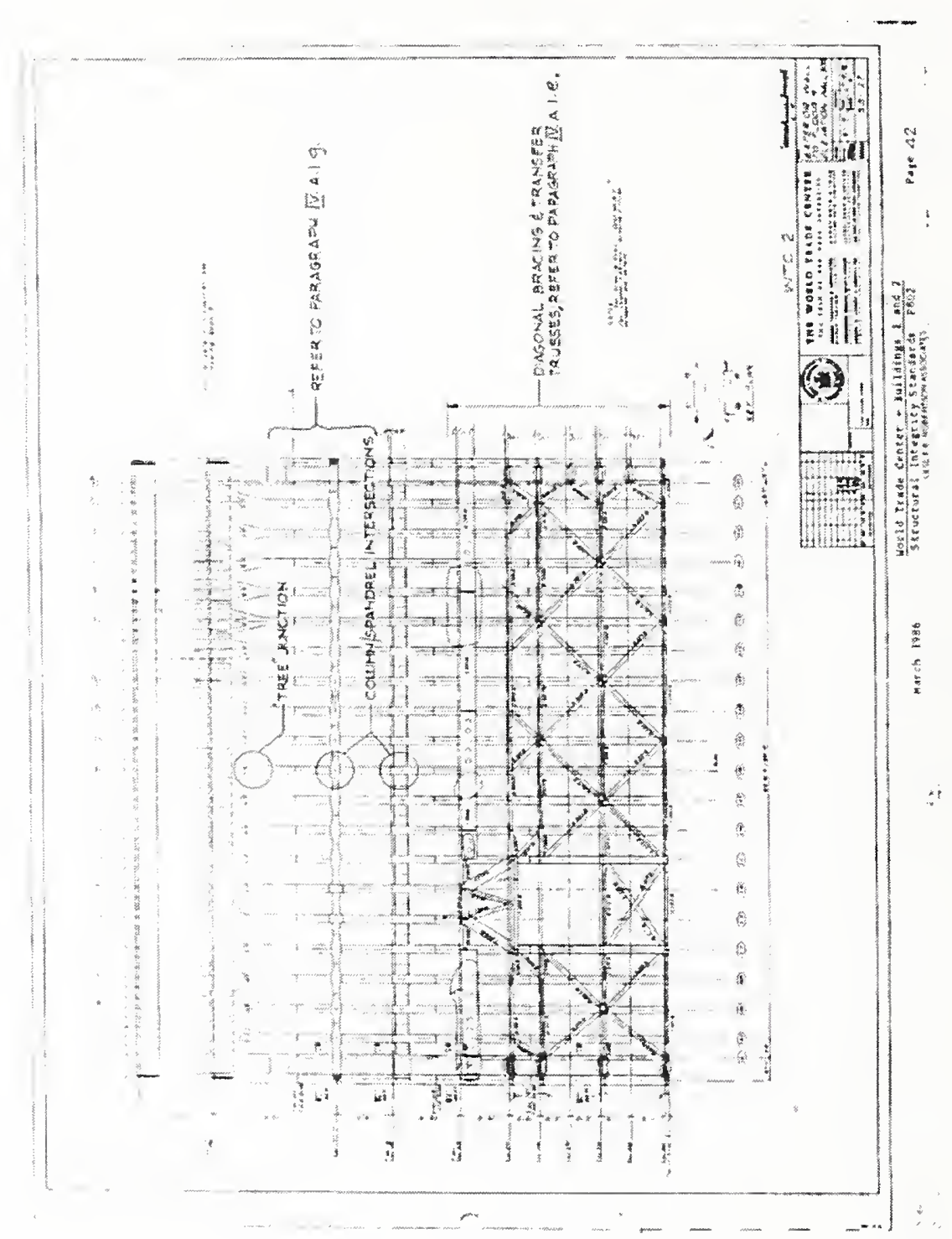




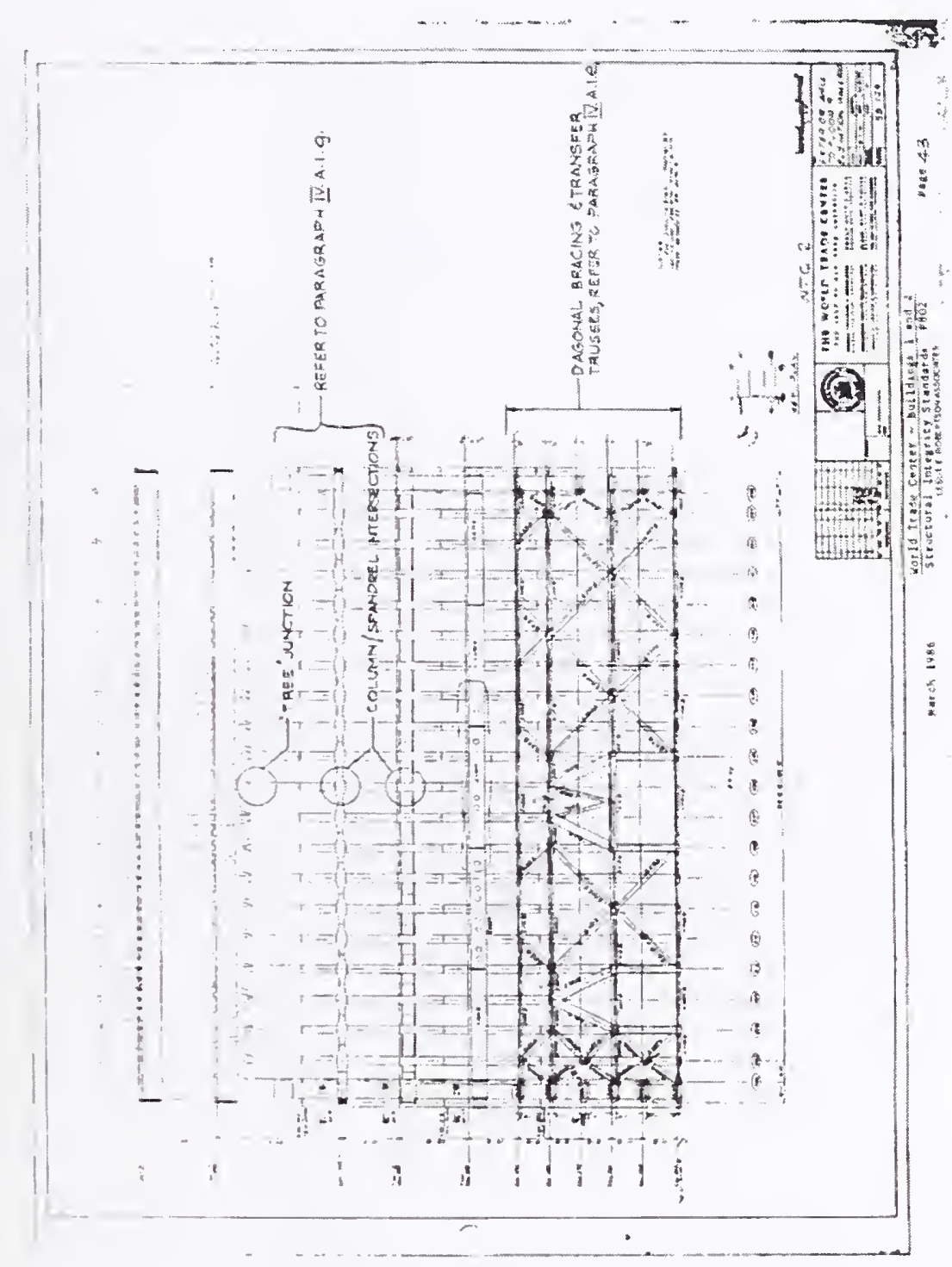




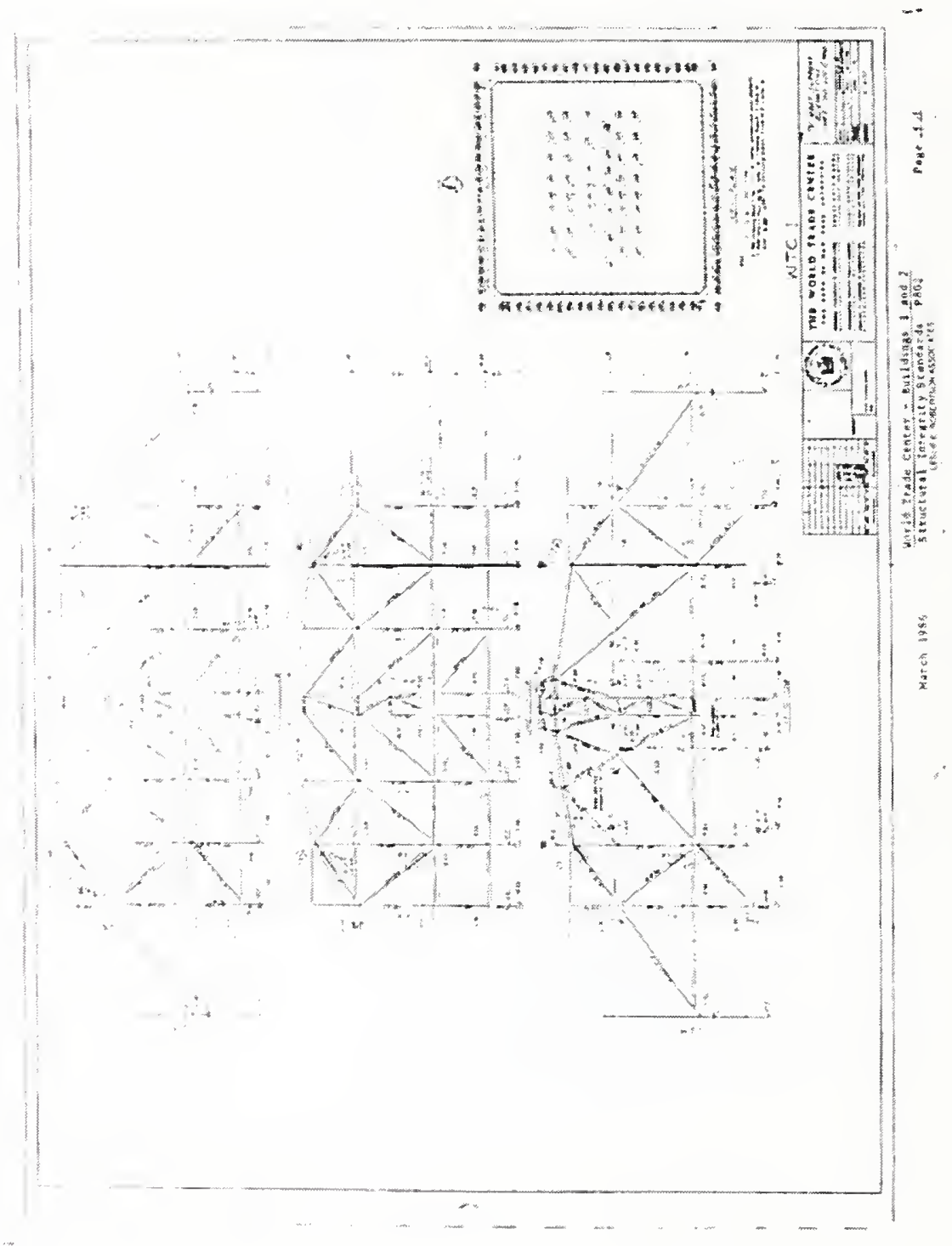




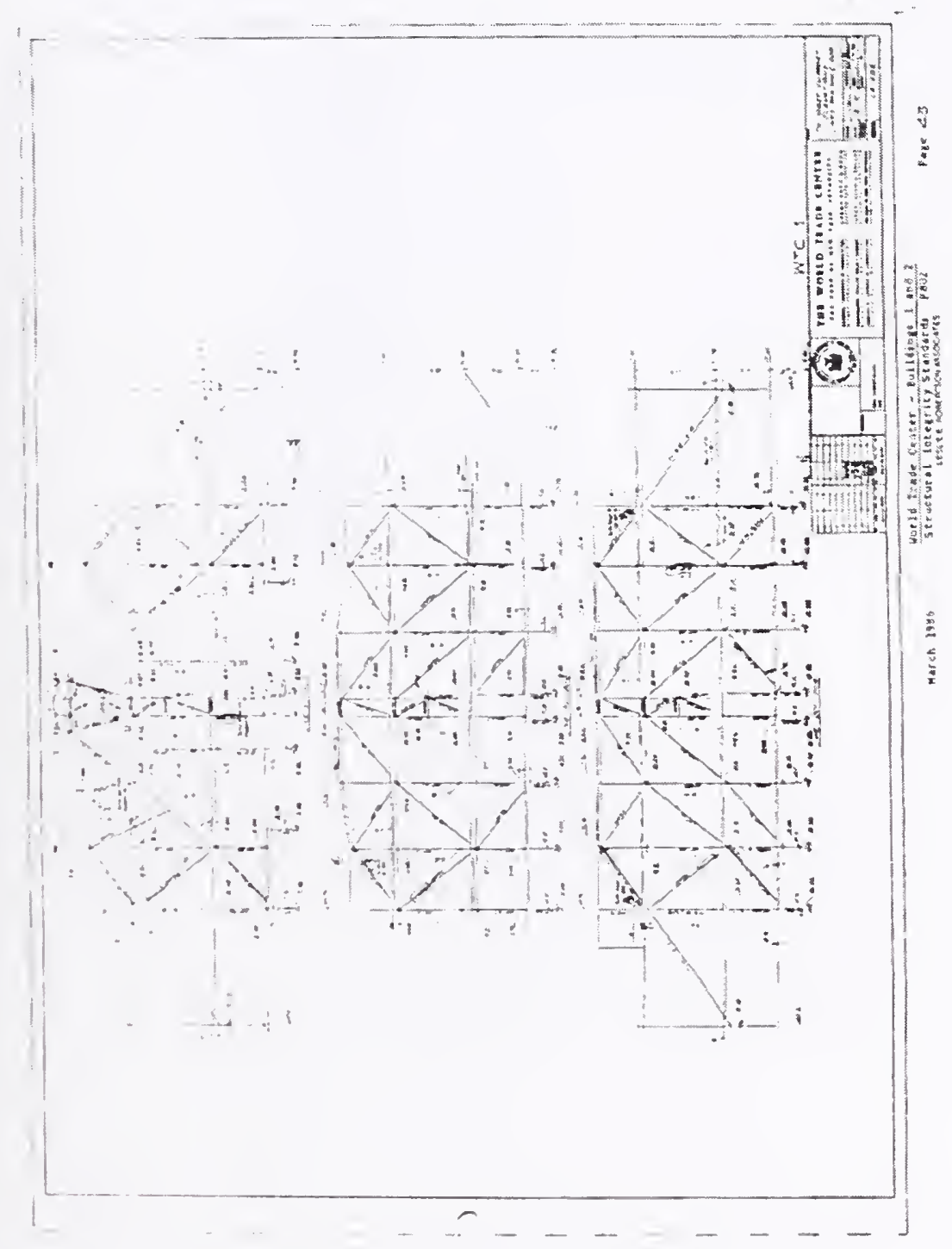




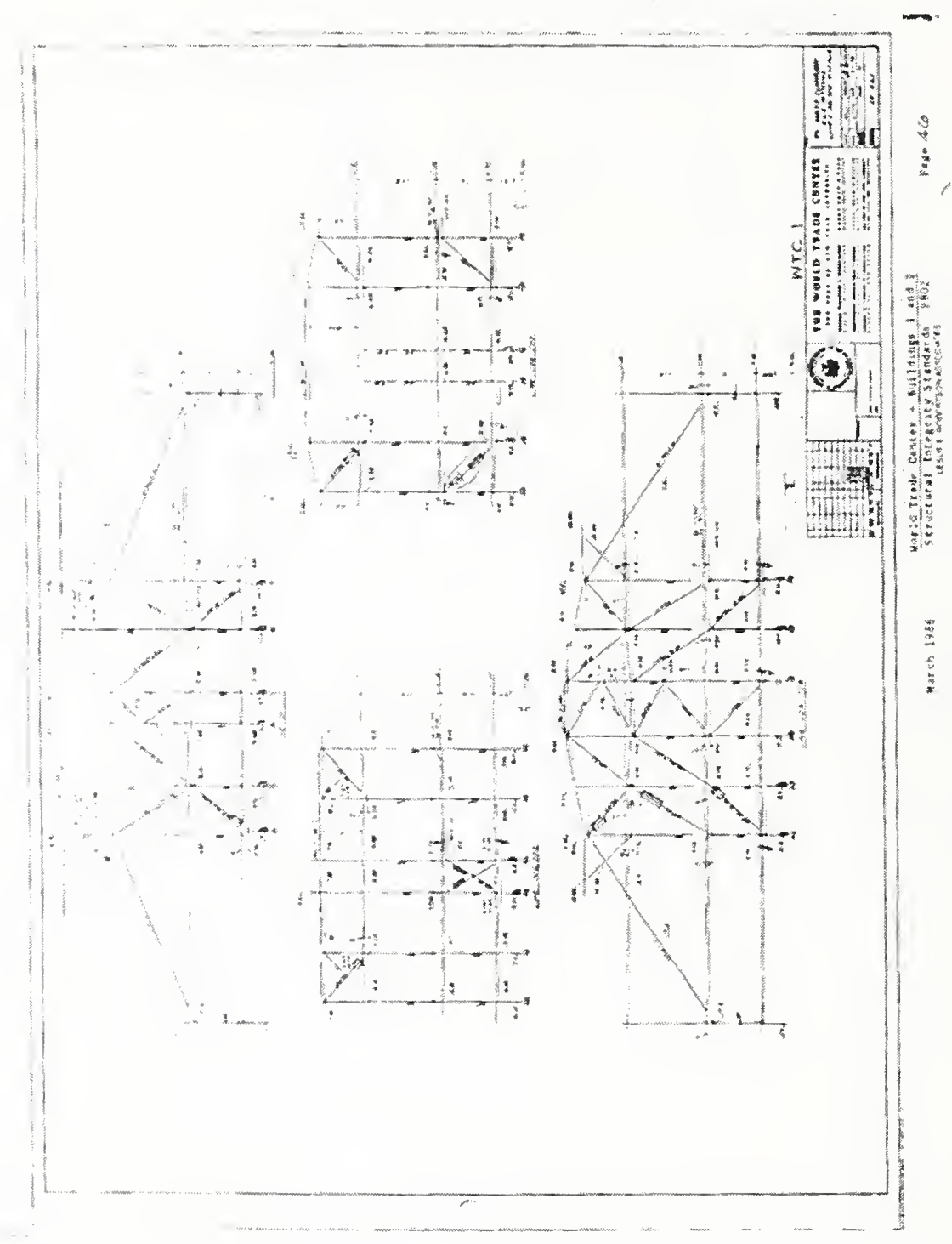




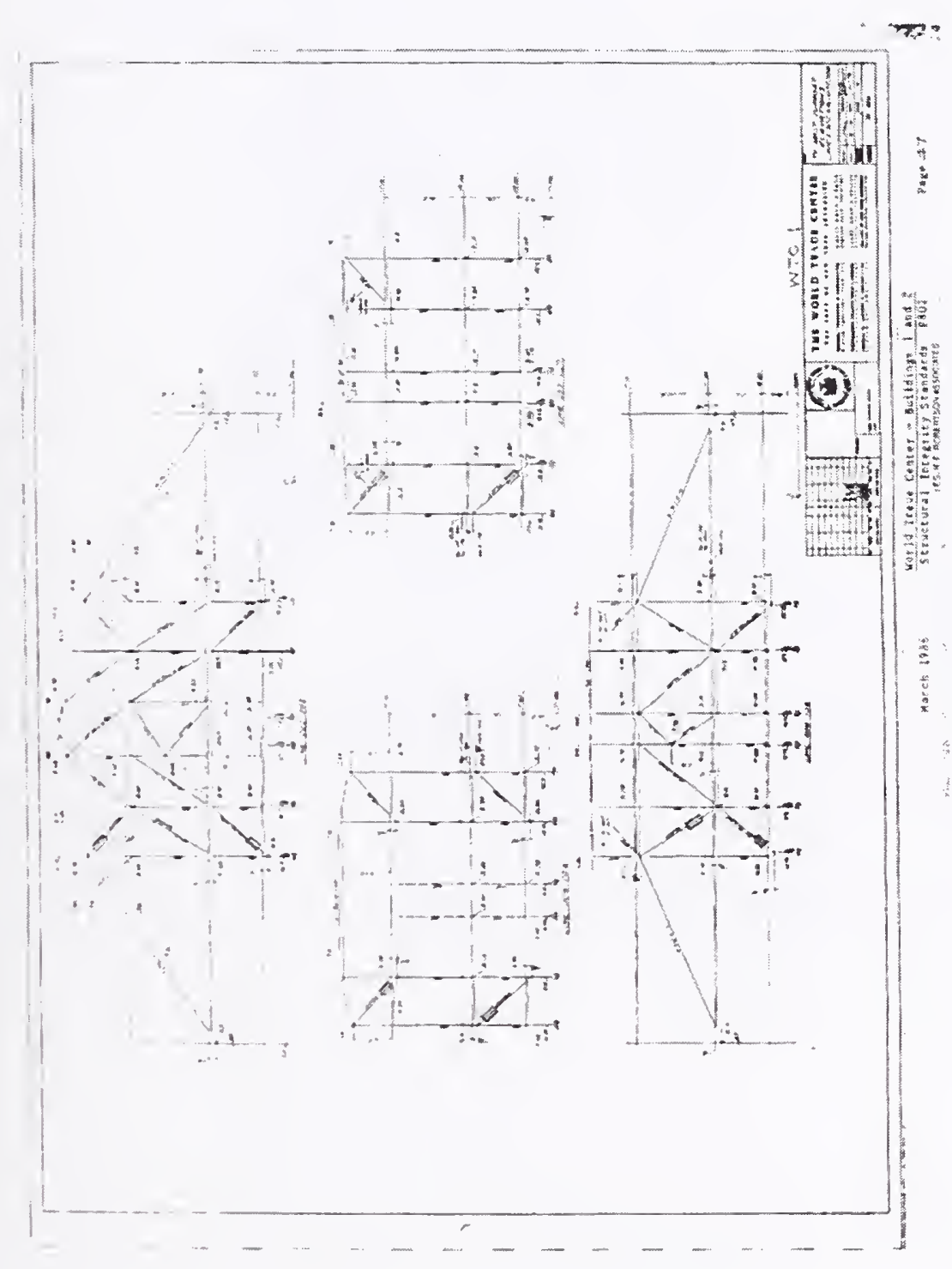




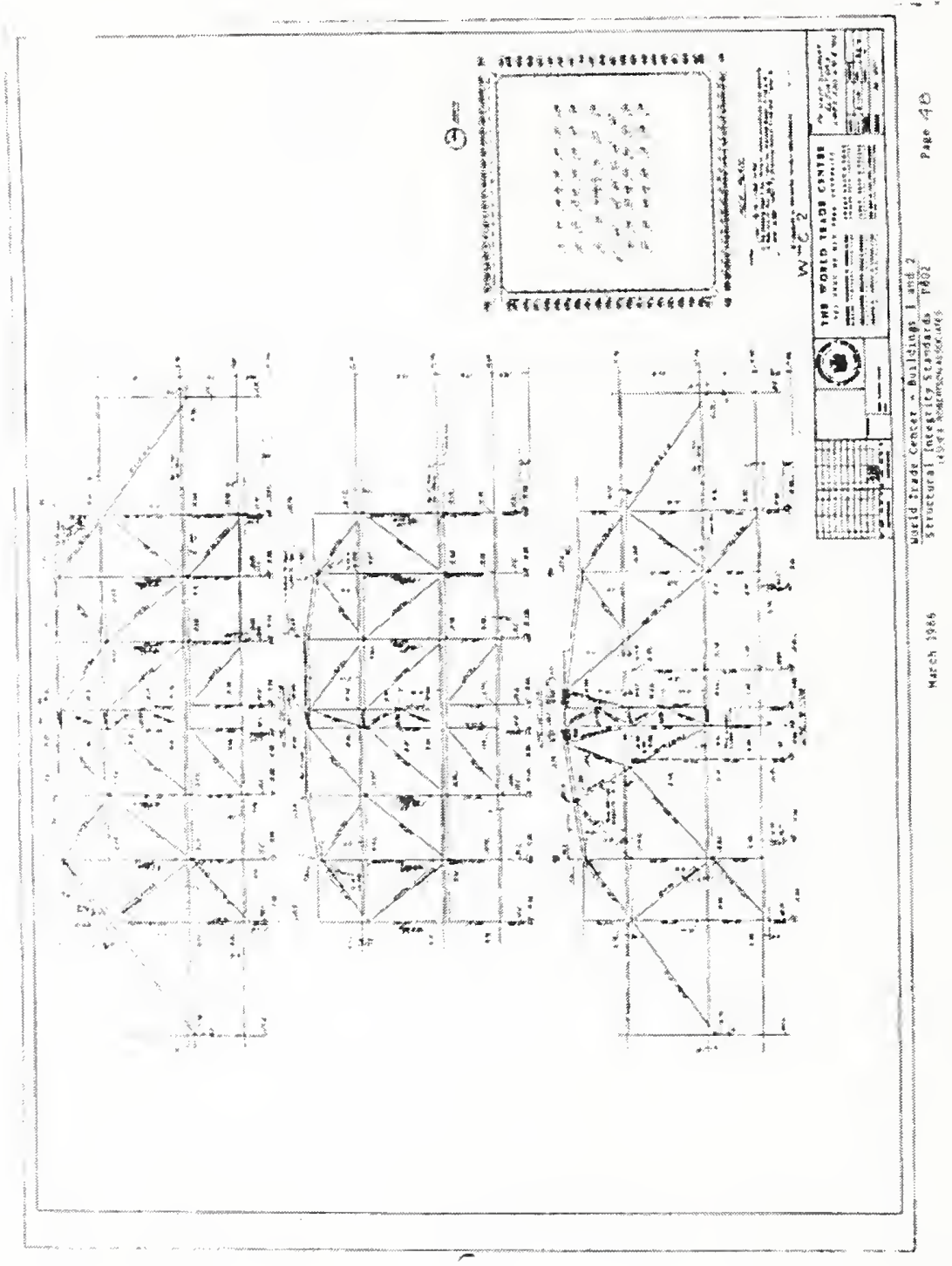




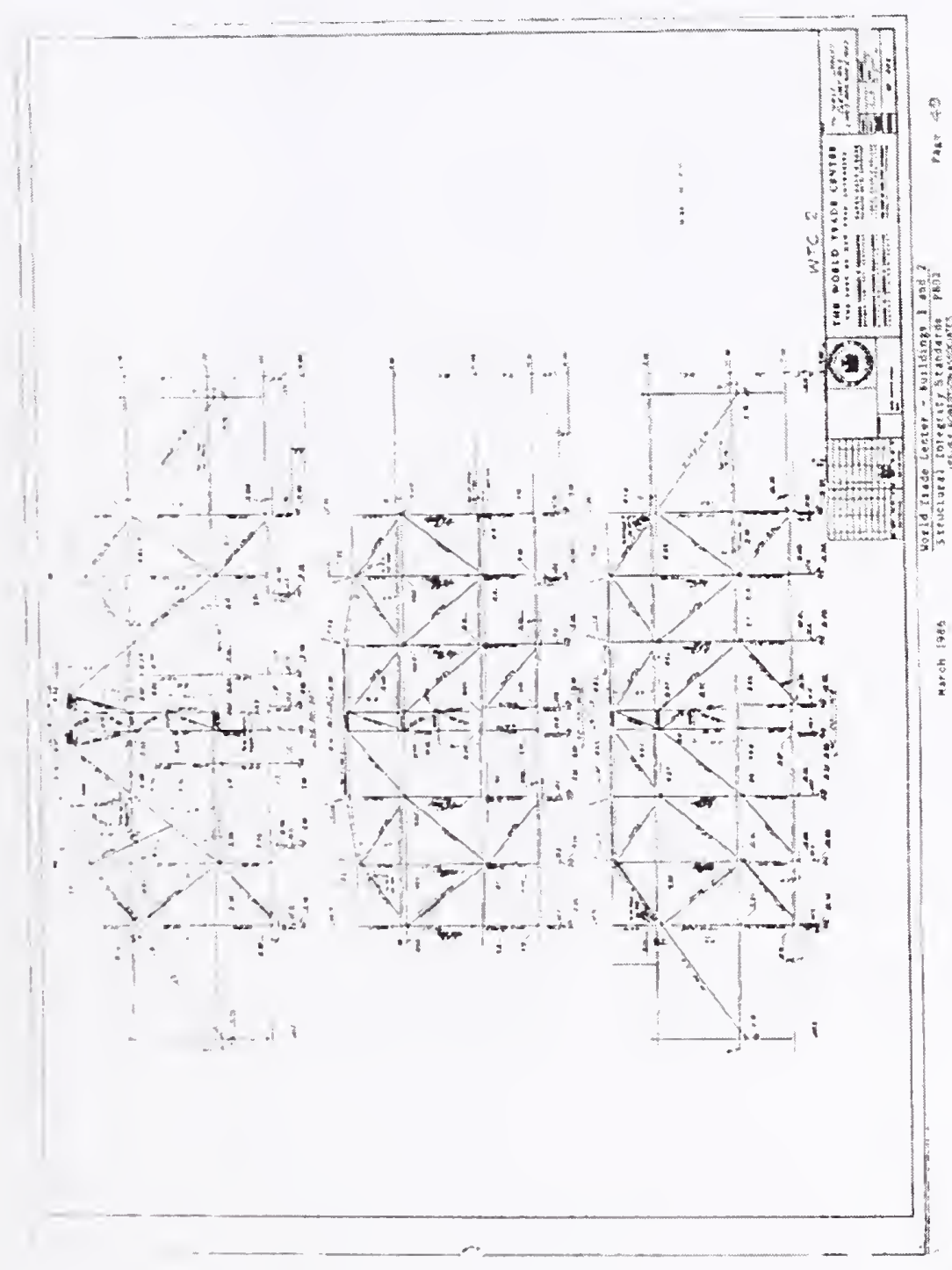




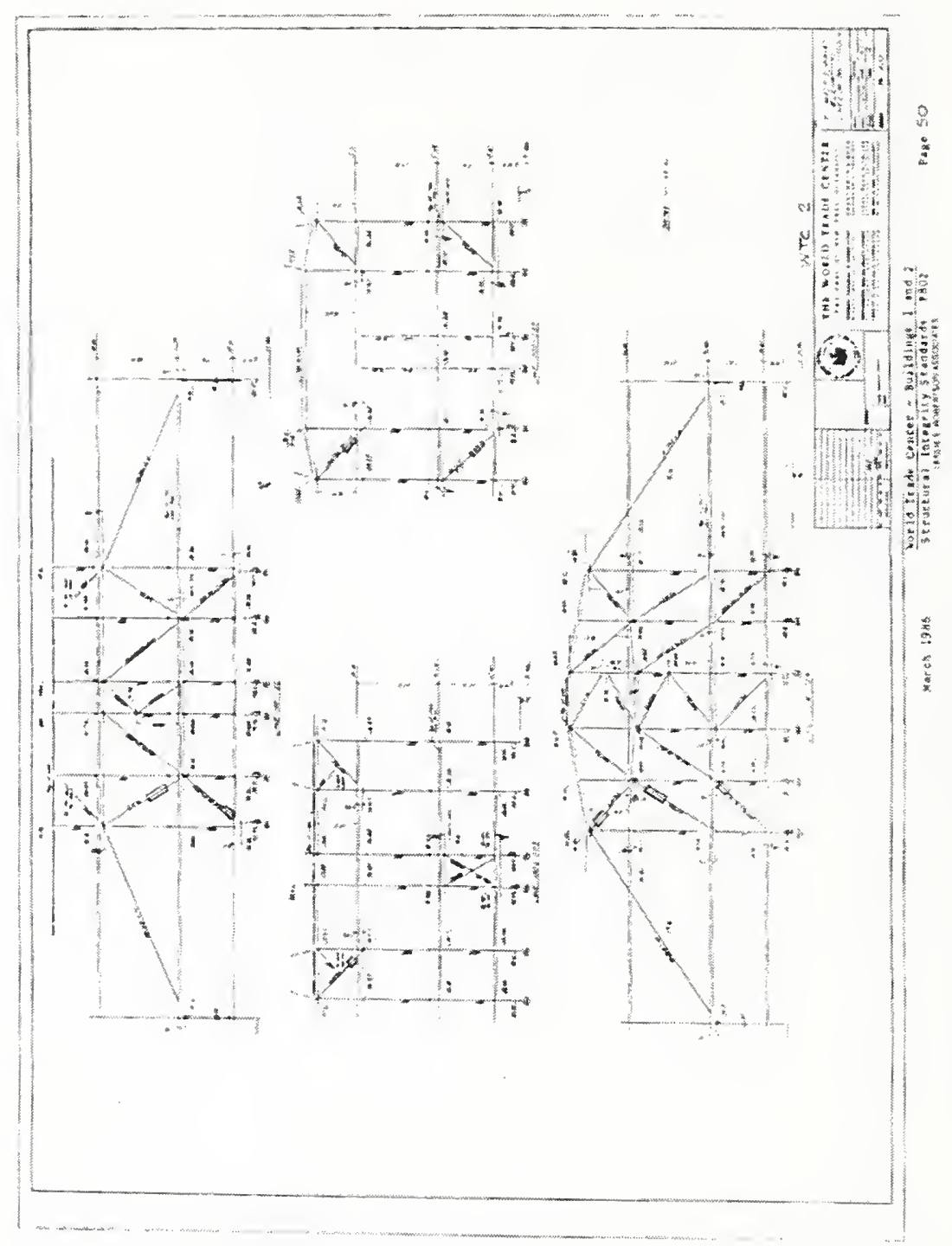




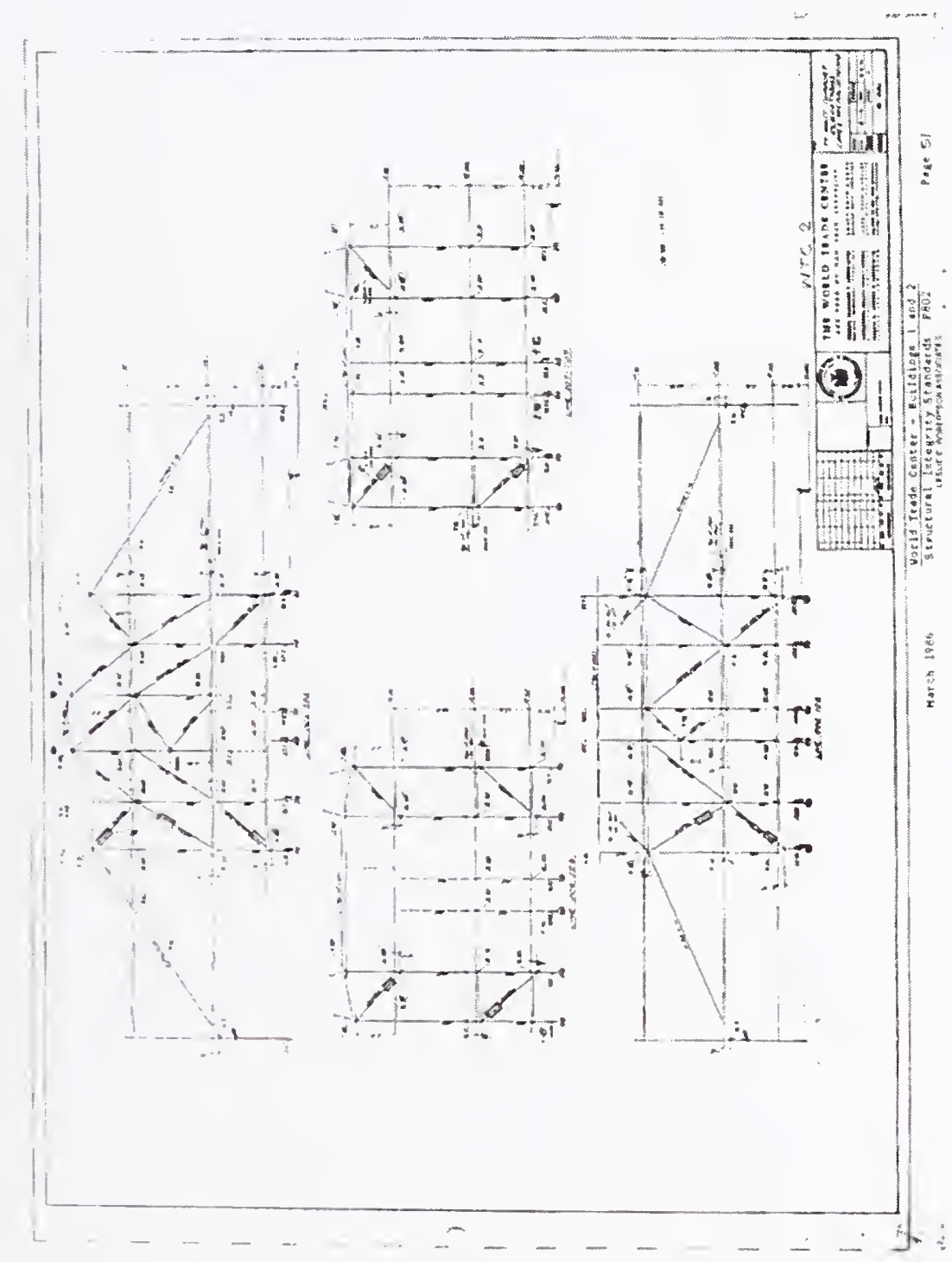


This page intentionally left blank. 


\title{
Appendix $F$ \\ ARCHITECTURAL AND STRUCTURAL DESIGN GUIDELINES, SPECIFICATIONS, AND STANDARD DETAILS
}

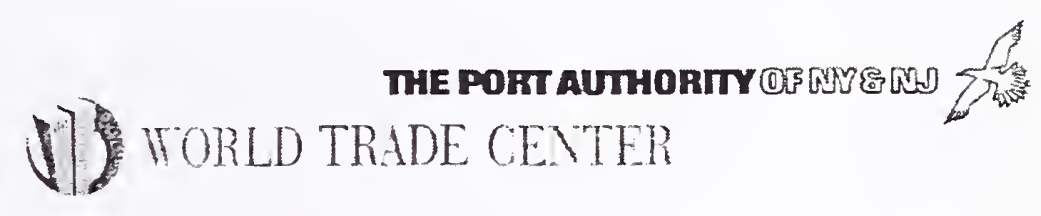

\author{
Architectural and \\ Structural Design \\ Guidelines, Specifications \\ and Standard Details
}

Architectural

Structural

February 27, 1998

Reproduced with permission of The Port Authority of New York and New Jersey. 
February 27, 1998

THE WORLD TRADE CENTER DESIGN GUIDELINES

STANDARDS FOR ARCHITECTURAL AND STRUCTURAL DESIGN 
STANDARDS FOR ARCHITECTURAL AND STRUCTURAL DESIGN

TABLE OF CONTENTS

SECTION IITLE PAGE

ARCHITECTURAL DESIGN GUIDELINES

$\begin{array}{lll}\text { A. } & \text { GENERAL } & 1 \\ \text { B. } & 3 \\ \text { C } & \text { MALL AND CEILING CONSTRUCTION } & 4 \\ \text { D. SPECIALT AND METHODS OF CONSTRUCTION } & 5 \\ \text { E. } & \text { CONTROLLED INSPECTIONS } & 5 \\ \text { F. SIGNAGE } & 6 \\ \text { G. SUBMISSION OF "AS BUILT" DRAWINGS } & 6 \\ \text { H. RETAIL AND PUBLIC SPACE TENANTS } & 6\end{array}$

\section{STRUCTURAL DESIGN GUIDELINES}

$\begin{array}{lll}\text { A. } & \text { GENERAL } & 7 \\ \text { B. } & \text { CALCULATIONS, LOADS AND DESIGN PARAMETERS } & 7 \\ \text { C } & \text { CORE HOLES AND OTHER SLAB PENETRATIONS } & 9 \\ \text { D. } & \text { HUNG CEILINGS } & 9 \\ \text { E. HVAC EQUIPMENT } & 10 \\ \text { F. WALLS } & 10 \\ \text { G. EXISTING STEEL } & 11\end{array}$

\section{STRUCTURAL DESIGN SPECIFICATIONS}

1. CORING CRITERIA AT TOWER PIT CELLS AND UNDER INDUCTION UNITS (for standard drawings STR-02 through STR-08)

2. LIGHT WEIGHT CEILINGS FOR TOWER FLOORS WIDOUBLE TRUSS (for standard drawings STR-09 through STR-14)

\section{ARCHITECTURAL STANDARD DETAILS}

$\begin{array}{ll}\text { ARCH-01 } & \text { DRYWALL PARTITION } \\ \text { ARCH-02 } & \text { 1-HOUR PARTITION } \\ \text { ARCH-03 } & \text { 1-HOUR RATED PARTITION WIOFF-SET } \\ \text { ARCH-04 } & \text { 2-HOUR RATED PARTITION } \\ \text { ARCH-05 } & \text { 2-HOUR RATED PARTITION WIOFF-SET } \\ \text { ARCH-06 } & \text { WALL PLAN AT CONVECTORS } \\ \text { ARCH-07 } & \text { HEAD DETAILIJAMB DETAIL (2-HOUR RATED) }\end{array}$


ARCH-08

ELEVATION DETAILS OF FIRESTOPPING OF

TYPICAL OPENING IN RATED WALL ABOVE CEILING

$\mathrm{ARCH}-17$

DETAIL OF RAISED FLOOR AT PERIMETER

INDUCTION UNITS

\section{STRUCTURAL STANDARD DETAILS}

STR-01

FLOOR LIVE LOADS - WTC TYPICAL TOWER FLOOR PLAN

STR-02

CORING CRITERIA - WTC TYPICAL TOWER FLOOR PLAN (See also

STR-03

STR-04

Structural Design Specifications, Section A

STR-05

CORING CRITERIA - DETAIL AT BUILDING PERIMETER

CORING CRITERIA - PART PLAN - FLOORS 45-48 \& 78-82

CORING CRITERIA - PLAN DETAIL OF SPACING AT OFFSET CORED HOLES

STR-DS

STR-07

CORING CRITERIA - REBAR SPLICE

STR-08

CORING CRITERIA - REBAR SPLICE

CORING CRITERIA - REBAR REPAIR

STR-09

LIGHT WEIGHT CEILING SUPPORT SYSTEM FOR FLOORS WITH DOURI = TRUSSES (See also WTC Structural Design Specifications, Section $B$ )

STR-10

LIGHT WEIGHT CEILING SUPPORT SYSTEM FOR FLOORS WITH DOUBLE TRUSSES - SECTION S-1

STR-11

LIGHT WEIGHT CEILING SUPPORT SYSTEM FOR FLOORS WITH DOUBLE TRUSSES - SECTION S-2

STR-12 LIGHT WEIGHT CEILING SUPPORT SYSTEM FOR FLOORS WITH DOUBLE TRUSSES - SECTION S-3

STR+13

LIGHT WEIGHT CEILING SUPPORT SYSTEM FOR FLOORS WITH DOUBLE TRUSSES - TYPICAL SECTION AT PARTITION WALLS

STR-14

LIGHT WEIGHT CEILING SUPPORT SYSTEM FOR FLOORS WITH DOUBLE TRUSSES - TYPICAL 2" CHANNEL SPLICE DETAIL

ATTACHMENT "A" - BS\&A RULE 501-68-SR - Rules for Goveming the Marking of

Iransparent Glass Doors and Fixed Adjacent Glass Sidelights Rule. 


\section{ARCHITECTURAL DESIGN GUIDELINES}

\section{A. GENERAL}

The following is a guide for the architectural design requirement and criteria for tenant alterations at the WTC. The scope of the architectural review shall be to ensure compliance with the applicable codes, standards, and WTD Design Criteria.

\section{ADA Compliance}

All tenant spaces must conform to the latest design criteria established by the Americans with Disabilities Act (ADA), and Local Law \# 58. A note specifying compliance should appear in each set of orawings. These requirements include but are not limited to the following:

a) HARDWARE - All hardware must conform to ADA requirements. Lever type knobs and panic bars are recommended for all doors.

b) ACCESSICORRIDOR DIMENSIONS - All spaces within the tenant area must be equally accessible to the handicapped as specified by the ADA.

c) STROBES - All areas must be furnished with strobe lights (vialual alarms). These strobes must be connected to the floor Class 'E' alarm system. See details in the Fire Alarm Design Guidelines.

d) TOILETS - Plans and elevations of the toilet for disabled people shall clearly show all critical dimensions as per ADA requirements.

\section{Asbestos}

A leasehold may contain vinyl asbestos floor tiles (VAT) which were installed during the initial construction of the World Trade Center. They are probably in good condition and, if not disturbed are safe. If a tenant is planning construction or any modifications which may disturb these tiles, the removal of the VAT is required. The tenant may choose one of the following options for the abatement of the VAT:

a) The tenant may obtain the services of a NYS Department of Labor licensed abatement contractor to remove the VAT. In this case a TAA must be filed with the Tenant Alteration Application Unit of the World Trade Department. Drawings of the required air lock enclosures and specifications for the asbestos removal must be submitted for review with copies of the contractors abatement licence and certificate of insurance. 
The tenant is required to submil documentation of the project once completed.

b) The tenant may retain the services of the World Trade Center Call-in abatement contractor. In this case the tenant must submit a written request to World Trade Department. Documentation will be issued to the tenant upon completion of the VAT removal.

3. Egress Analysis

An Egress Analysis shall be a part of all submissions in which the proposed work effects the movement of people through the space. This analysis will include at minimum, the following information:

a) Construction Classification/Occupancy Classification

Generally office space and related spaces shall be designed to meet the requirements of occupancy Group E classification and Construction Class I-B, in accordance with the latest edition of the NYC Building Code.

Indicate the occupancy classification for all equipment and storage rooms (indicate type of storage) to ascertain the proper fire resistance rating for walls separating these rooms. Indicate the type of construction used to obtain the fire rating for all demising walls.

b) Entrance and Egress

All exit doors and their sizes to be used to exit any space must be indicated on the drawing. as well as the allowed occupant load per exit width as per NYC Building Code.

c) Travel Distances

Travel distances to primary and secondary exits must be indicated following the path of travel through each space.

No equipment, partitions, fixed tenant installations, or other facilities should be located where they may block or interfere with egress.

4. Occupant Load

The office floors have been designed to sustain a live load, including partitions, which shall not be exceeded. In areas where there is a concentration of files, storage, or heavy equipment, verification of the structural integrity of the floor system in these areas is required. See the Structural Design Guidelines for details. 


\section{B. WALL AND CEILING CONSTRUCTION}

The WTD has available for the tenant's architectengineer standard reference details which show examples of the depth and clarity of information required to be shown on the drawing for the construction of various wall and ceiling types. See attached WTC Standard Architectural and Structural Details.

\section{Core Walls} Code.

All core wall shall have a 2-hour fire rating as required by the NYC Building

2. Demising Walls

Walls separating tenants shall have a minimum 1-hour fire rating unless otherwise indicated by occupancy/use group.

\section{Corridor Walls}

Corridor walls shall have a fire-resistance rating of 2-hour as required by WTC and have a self-closing swinging type doors $1-1 / 2$ fire resistancerating.

\section{Ceiling Construction}

On tower floors with double trusses the WTC requires the suspended ceiling to be installed as detailed on the Standard Architectural Details STR-10 through STR-14 attached. All other areas and special installations must meet the requirements of the New York City Building Code.

A BS\&A or MEA resolution of approval is required for ceiling tiles.

5. WTC Standard Ceilings

The new building standard suspended ceiling in public corridors is, 24 " $X 24$ " $X$ $3 / 4^{\prime \prime}$ mineral fiber lay-in tile, Ultima RH9O, beveled tegular, No.1782 for 9/16" slotted tee grid, by Armstrong.

\section{MATERIALS AND METHODS OF CONSTRUCTION}

No material, assemblies, forms, method of construction, equipment, machinery and devices will be acceptable for the intended use unless: 
Accepted by the Code test method by the Materials and Equipment Acceptance (MEA) division of the Office of the Commissioner of the Buildings Department of New York City.

OR

Approved by the New York City Board of Standards and Appeals (BS\&A)

Resolutions of MEA or BS\&A shall be submitted for review. Manufacturers' or distributors' letters will not be acceptable.

1. Floor Coverings

The architect or engineer-of-record is required to obtain, certify, and supply for review documentation that the carpet has been tested by an independent laboratory (approved by the City of New York), showing the complete test data results in accordance with the New York City Building Code. Manufacturer's or supplier's data is unacceptable.

Carpet and carpeting assemblies shall not be installed in stairways designed to meet building code exiting requirements.

Carpets should be (but are not required to be) installed utilizing the "tackless" method which allows easier removal under the tenant's restoration obligation. The padding should be cemented to the subfloor at the perimeter with a "release" adhesive. Adhesives in all instances must be non-flammable. If rubber padding is used, all seams must be taped.

The tenant is required to provide all necessary access to trench header ducts and junction box cover plates for under floor conduit systems. If access is not provided, the tenant assumes all costs associated with the pulling-back, removing, and reinstalling of the carpet.

\section{Raised Floor Systems}

All raised floor systems must have a BS\&A or MEA Resolution capable of withstanding the imposed loads.

For a raised floor not more that $10^{\prime \prime}$ in height, a minimum of $1-1 / 2$ " clearance is required between the edge of the raised floor and the induction unit (IU) enclosure. For furniture or a raised floor more than $10^{\text {" }}$ in height, a minimum of 6 " clearance shall be maintained between the edge of the raised floor and the front of the induction unit enclosure. Additional removable floor grilles should be installed on the edge of the raised floor in front of the induction unit. See 
Architectural Detail ARCH-17 for installation of raised floors which meet at the perimeter induction units.

3 Window Treatments

The WTC standard window covering is a horizontal blind, brushed aluminum finish, with 1 " slats.

4. Transparent Glass and Fixed Adjacent Glass Sidelights

Transparent glass walls are required to be marked as per BS\&A Rule 501-68$S R$, Rules for Governing the marking of Transparent Glass Doors and Fixed Adjacent Glass Sidelights Rule. (See Attachment " $A$ " to these guides)

5. Fire Shutters

Where spaces are provided with automatic fire shutters used to maintain the fire-rating, a safe means of egress shall be provided for persons who may remain inside the space after the grill is closed due to fire emergency. This additional egress must be in accordance with code requirements.

6. Fabric and Vinyl Wallenverings

All fabric and vinyl wall coverings must have a copy of the BS\&A or MEA resolutions submitted for approval.

\section{SPECIALTY ROOMS AND EQUIPMENT}

1. Storage Areas

Provide appropriate fire separations according to occupancy classification as per the NYC Building Code.

2. Computer Rooms

See the Mechanical and Fire Protection Guidelines for inclusion of Pre-action and Halon fire suppression systems.

\section{E. CONTROLLED INSPECTIONS}

All materials, equipment, and construction designated by the Code for "controlled inspection" shall be inspected and/or tested to verify compliance with the Code. Controlled inspections shall be made and witnessed by or under the direct supervision 
of a registered architect (PA) or professional engineer (PE) retained by the tenant and acceptable to the architect or engineer responsible for the plans. The inspecting RA or PE shall be independent of the contractor.

\section{F. SIGNAGE}

1. Office Tenants

The World Trade Center will provide each tenant with one door sign and directory listings in the main lobby, skylobby and on the tenant's floor. Each tenant is entitled, by lease to a $12^{\prime \prime} \times 12^{\prime \prime}$ acrylic door sign engraved with the company name and suite number.

Tenants who desire a non-standard door sign must first obtain approval of the WTD's Tenant Services Unit before proceeding with any such installation. The maintenance, repair, replacement, etc. of non-standard door signs, is the sole responsibility of the tenant.

\section{G. FINAL SUBMITTAL}

All alterations made to tenant spaces must have "AS BUILT" drawings submitted to the Tenant Alterations Unit of the World Trade Department upon completion of the job. Such AS BUILTS shall be submitted in the form of one complete set of Mylar reproducible drawings stamped AS BUILT and signed and verified by the consultant of record and the contractor and one (1) cadd disk (3-1/2", 1.44 mega Bytes floppy).

The architect shall state in the general specification the submission of such AS BUILTS

H. RETAIL AND PUBLIC SPACE TENANTS

See "Interim Tenant Design Criterial" for aesthetic criteria in public spaces at the World Trade Center. 


\section{STRUCTURAL DESIGN GUIDELINES}

\section{A. GENERAL}

Before starting any design work, the tenant's consultants must perform a fietd inspection of all pertinent areas to verifythat they have the latest information about all structural elements. This includes information about truss reinforcement, if any, stair openings in slab and core-hole locations.

All calculations and construction drawings shall be submitted to the Port Authority for review and approval, and must be signed and sealed by a professional engineer or registered archited who must be licenced to practice in the state of New York.

Whenever calculations are submitted, a statement shall be made next to the seal on the cover sheet that "the professiona seal and signature affixed hereon is all inclusive for the full contents of this document." Alternatively, a separate seal and signature on each individual calculation sheet will also be acceptable. Four sets of calculations will be submitted with the first submission, and four copies of each revised sheet in any required subsequent submissions.

\section{B. CALCULATIONS, LOADS, AND DESIGN PARAMETERS}

The proposed floor loads shatl be compared with the allowable design loading. Drawing STR-01 shows the allowable loading for a typical tower floor and also indicates limitations on the dimensions of concentrated loads. The design loads take into consideration all live load reductions on the trusses and also include the weight of partitions. For additional information or information on the other buildings in the complex contact Mr. Suren Batra WTC Structural Engineer, at (212)435-2409

The tenant's loads must nol overstress the existing structural system. If required, the floor system can be reinforced. Calculations to compare the proposed loading with the allowable, and any revision to the floor system shall be made in conformance with the latest edition of the NYC Building Code. Both, "Allowable Stress Design" and "Load Resistance Factor Design," are acceptable methods of design.

When applicable, in place of a detailed investigation of the stresses in the existing structure, the moments and shears due to the tenant's proposed live loads may be compared with the moments and shears produced by the original design live loads shown on drawing STR-01. 
The comer sections of a typical floor, work as a two-way truss system. Portions of the corner areas can take greater loads than those shown on drawing STR-01. An analysis of the tenant's loads based on a two way truss grid may yield satisfactory results for higher loads placed in a non-critical area of the corners.

To cover an existing floor opening by a slab, all structural elements shall be designed for the strength of the adjacent existing areas, and not the theoretical design loads. This is particularly necessary for any slab which has an overload capacity to support local concentrated loads.

Show and locate on the construction drawings:

a. The weight of any equipment, or cluster of equipment, exceeding $500 \mathrm{lbs}$.

b. All files and shelves. Provide a legend showing each type of file or shelving unit, and indicate the size and number of tiers for files and the height for shelves.

The following minimum loads shall be used for calculations when applicable:

a. File cabinets: 33 psf per tier, includes the weight of the cabinet.

b. Open shelves for paper storage: $46 \mathrm{pcf}$ of the net volume plus the weight of the shelves.

c. Mechanized file storage: Use the manufacturer's indicated fully loaded weight, or the net weight of the storage unit plus 46 pcf for contents.

d. Libraries:

1) Aisle loading:

-for aisle width equal to or less than $30^{\prime \prime}$, use 30 psf.

-for aisle widths greater than $30^{\prime \prime}$, use 60 psf.

2) Reading areas $-60 \mathrm{psf}$.

3) Open shelves - $46 \mathrm{pof}$ of the net volume plus the weight of the shelves.

e. File rooms aisle loading:

-for aisle widths equal to or less than 30 ", use 30 psf.

-for aisle widths greater than 30", use 50 psf. 
Bases (and heads) for rail posts, auxiliary columns, etc. shall be designed for the required loads. Plates and bolts are to be fully detailed on the drawings, including the location and number of anchor bolts, manufacturer, type, size, embedment length, etc.

Wherever proprietary devices are used to transfer loads, submit for review. the BS\&A number, the manufacturer's name, and a catalog cut.

\section{CORE HOLES AND OTHER SLAB PENETRATIONS}

A survey of slab penetrations in the vicinity of the proposed cores shall be submitted as early as possible in the review process, so that the need for repairs to the existing cores may be determined. Repairs shall be made as per attached details STR-06 through STR-08

Proposed penetrations or cores in the slab shall be clearly identified on the construction drawings for the trade that is expected to do the coring.

The dimensioned location of all new penetrations or cores shall be shown on the "As Built" drawings.

Proposed penetrations or cores in tower slabs shall meet the criteria for location, spacing, etc. as specified in the attached drawings STR-02 through STR-08, and Sructuctural Design Specifications, page 12. New penetrations or cores are not allowed in "Prohibited" areas. Penetrations or cores may be located in "Restricted" areas. However, damaged steel must be repaired as per details shown on drawings STR-06 through STR-08. It is advisable to avoid "restricted" areas in the design. Each "restricted" area penetration or core shall be labelled as such on the drawing and reference made to STR-06 through STR-08, which shall then be included in the contract set.

Proposed cores in the vicinity of "Prohibited" or "Restricted" areas, shall be dimensioned on the drawings using the face of the glass as a reference.

\section{HUNG CEILINGS}

Where new ceilings are to be installed, unless otherwise noted, it will be assumed that the existing ceiling suspension system will be removed and replaced.

For ceilings in the double truss areas of the towers, the span between trusses requires that the size of the carrying channels and caddy clips be larger than that required by the NYC Building Code. Provide the details shown on Drawings STR-09 through STR14 on the construction drawings. 
The carrying channels must be perpendicular to the existing trusses. Concrete anchors into the slab shall only be used:

1. At the end of the trusses where the truss lower flange is at a higher than normal elevation (see Section S-1, on STR-10) and,

2. Where the the hung ceiling is not continuous at a partition and there is no truss within 10" of the partition (see STR-13, "Typical Section at Partition Wall."). In all other cases the ceiling rods shall be hung from the trusses.

In the rest of the facility (without double trusses), the ceiling shall comply with the NYC Building Code, Reference Standard 5-16, figures 3A, 3B and 3C. Concrete anchors shall be one of the preapproved anchors listed in the Ștructural Design Specifications, Section B. A complete detail with all the specified materials shall be shown on the drawings. The detail shall include the type and size of materials and the embedment length of anchors.

\section{E. HVAC EQUIPMENT}

For all HVAC equipment provide on the drawings the weight, dimensions, the proposed locations, and specify whether they are floor mounted or hung from above.

For hanging ducts, fans and $A C$ units under 500 lbs., refer to the details shown on Drawings HVAC-21 through 28 . The tenant's consultant is still responsible to verify the integrity of the existing structure from which the units are hung (information on the tenant loading from the floor above is available from WT Tenant Services). Where the weight of the unit exceeds the limits shown on the above drawings, calculations must be provided showing that the unit's proposed support system can carry the load.

For floor mounted equipment, provide calculations showing that the existing construction will not be overstressed due to the weight of the units and show all mounting details on the drawings.

\section{F. WALLS}

Where there is a wall over an opening such as a door or over a non-supportive material such as plastic, glass, etc., either a suitable lintel shall be designed or the wall may be suspended by studs from above. However, the top and bottom connections and diagonal braces attached to the slab above (where required for stability of the wall) shall be appropriately desinged and detailed on the drawings. 


\section{G. EXISTING STEEL}

Holes shall not be made in existing steel for hanging purposes. Welds shall not be made to the trusses. BS\&A or MEA approved clamps shall be used. 


\section{STRUCTURAL SPECIFICATIONS}

\section{CORING CRITERIA AT TOWER PIT CELLS AND UNDER INDUCTION UNITS}

\section{Scope and General Notes}

1. This criteria applies only to those holes cored into the Power/Telephone cells and under induction units and only in the following typical tenant floors:

1 WTC $\quad 10$ to 40,45 to 74,78 to 105

2 WTC $\quad 14$ to 40,45 to 74,78 to 106

2. For modifications of criteria at stair and escalator openings at floors 45 to 48 and 78 to 82 in both towers see Drawing STR-04.

3. Existing cored holes being reused are to be included in this criteria.

4. Maximum core size is 4" diameter, where permitted. Minimum average center to center spacing along a Power/Telephone cell for any four (4) consecutive cored holes including abandoned and filled holes is 1 " -4 ". For restricted and prohibited zone destinations, see notes 5 and 6 . For spacing criteria along Power/Telephone cells adjacent to holes offset from cells. see Drawing STR-05.

5. Restricted Zone:

Carefully locate cores to avoid cutting $\# 4, \# 5$ and $\# 5$ rebars, or repair cut and damaged rebars.

Where the proposed location of a new hole can be changed in order to clear the existing rebars and avoid the need for repairs, use a bar locater or electric harnmer the slab to locate the rebars.

See Drawing STR-06 through STR-08 for rebar repair details.

6. Prohibited Zones:

Coring is prohibited, except within the induction units at the Power/Telephone Cells only, which should be considered a restricied area and as noted in part plan detail at building perimeter. See Drawing STR-03.

See Drawings STR-06 through STR-08 for rebar anchor repair details. 
7. Existing cored holes which are to be abandoned and which do not have damaged rebars or column straps are to be filled with non-shrink grout. See detailed requirements rider $\mathrm{C}$, paragraph 15 of the Tenant Alteration Application. Abandoned core holes which require repairs to straps will be repaired by the Port Authority.

8. Where concrete or fill material is to be removed, exercise due care not to damage existing reinforcement. Under no circumstances should column strap anchors be damaged.

9. Extension dimension are measured from the glass face at the exterior wall.

10. Drawings of the proposed core locations are to be submitted by the tenant for review. World Trade Construction must be notified in advance when coring or other work is to start so that provisions can be made for inspection.

11. Remove rust, grease, cement and other contaminants from structural steel and rebar surfaces before welding.

12. Tenant shall submit certification that welders are qualified in accordance with the NYC Building Code and with applicable laws and requirements for each specific welding procedure and process which the welder will use in the work.

13. Where information in the drawing conflicts with information in Rider $\mathrm{C}$ of the Tenant Alteration Application, this drawing govems.

\section{Codes and Material}

1. All work shall conform to the requirements of the New York City Building Code, latest edition and revision.

2. Where more stringent, the latest edition, with supplements to date where applicable, of the following codes shall apply to the work:

a. American Institute of Steel Construction, "Specification for the Design, Fabrication and Erection of Structural Steel for Buildings." Supplement 1 is specifically excluded.

b. American Concrete Institute, "Standard Building Code Requirements for Reinforced Concrete" (ACl 318).

c. American Welding Society, "Structural Welding Code - Structural Steel (AWS D1.1) and Reinforcing Sleel" (AWS D1.4). 
3. Added structural steel plates shall conform to ASTM A36.

4. Added rebar shall conform to ASTM A615, Grade 60.

5. Welding materials for structural steel shall be E7018 conforming to AWS A5.1 "Specifications for Covered Carbon Steel Arc Welding Electrodes." -

6. Welding materials for reinforcing steel shall be $\mathrm{E7018}$.

7. Non-Shrink Grout shall be Crystex by L\&M Construction Chemicals Company, or an equivalent material acceptable to the WTC. 


\section{LIGHT WEIGHT CEILING SUPPORT SYSTEM FOR FLOORS WIDOUBLE TRUSS} NOTES:

\section{Materials}

Concrete Anchors - 3/8" diameter Liebig safety bolts (type LSN or LSH) with a minimum embedment length of $1-3 / 4^{*}$, or Hilti HSL or HSLB anchors, size M8 with a minimum embedments length of $2-1 / 2$ " and a maximum embedment length of $3^{\prime \prime}$.

Clip Angles - Hot rolled ASTM A36 steel.

Hangers - 1/4" diameter A36 galvanized steel rod

Camying Channel - $2^{\text {" }}$ cold rolled channels ( $\mathrm{F} y=33 \mathrm{ksi}$ minimum). Minimum weight $590 \mathrm{lbs} .14,000$ linear feel (painted).

Hanger to truss connection - at cover plate only

a. Thickness of bottom flange of truss $t<0.75$ ":

Caddy heavy duty flange clamps manufactured hy Erico Products Inc. BSA 1312-64-SM.

b. Thickness of bottom flange of truss $t>0.75^{\prime \prime}$ :

Universal C-clamp Fig. 93 (wide throat) 0.41 pounds each as manufactured by Grinnell Corp., or approved equal. Install C-clamp with set screw in top position.

Hanger to carrying channel - Caddy Gat channel clamp, Model 4B2LS, as manufactured by Erico Products Inc. BSA 131-68-SM.

Wire ties - 16 Gauge stainless steel AISI - Type 304 Monel metal.

2. Removal of fireproffing shall be kept to a minimum and shall be replaced by the contractor as directed by the Port Authority.

3. The contractor shall be required to submit catalog cuts, samples, layout drawings and details of all components of the ceiling support system for the Port Authority's review and approval prior to the start of any work in the field. 
4. The Ramset fastening system with Ladd drive pin number 684 (1-1/2" long), power level "RED" for installation, and the Ladd ceiling clip number 651 is permitted to substitute the hanger top connection detail shown in Section S-1 on STR-10, anchored into 3000 psi light weight concrete slab over galvanized metal deck. 

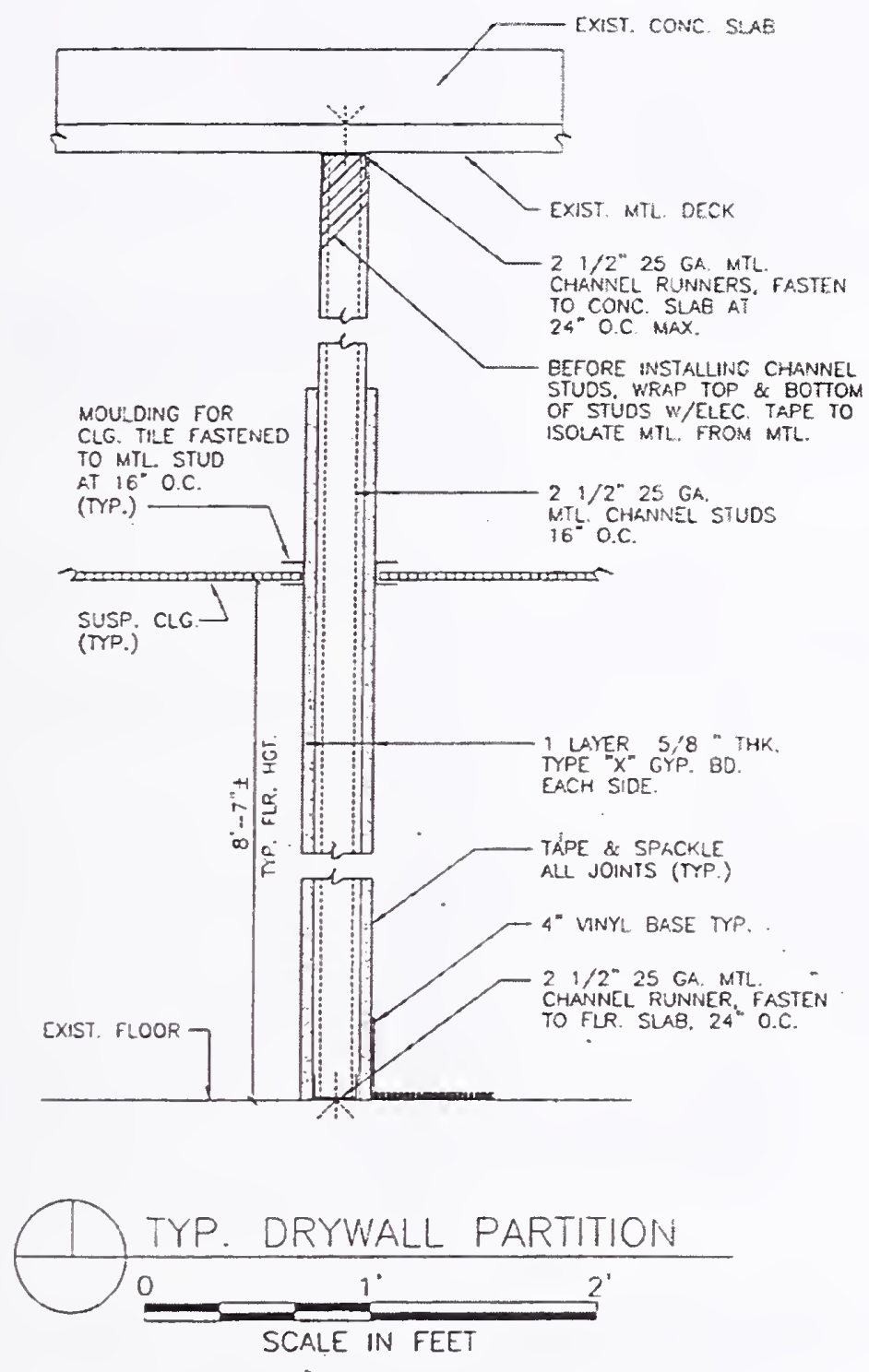

ARCH-01 


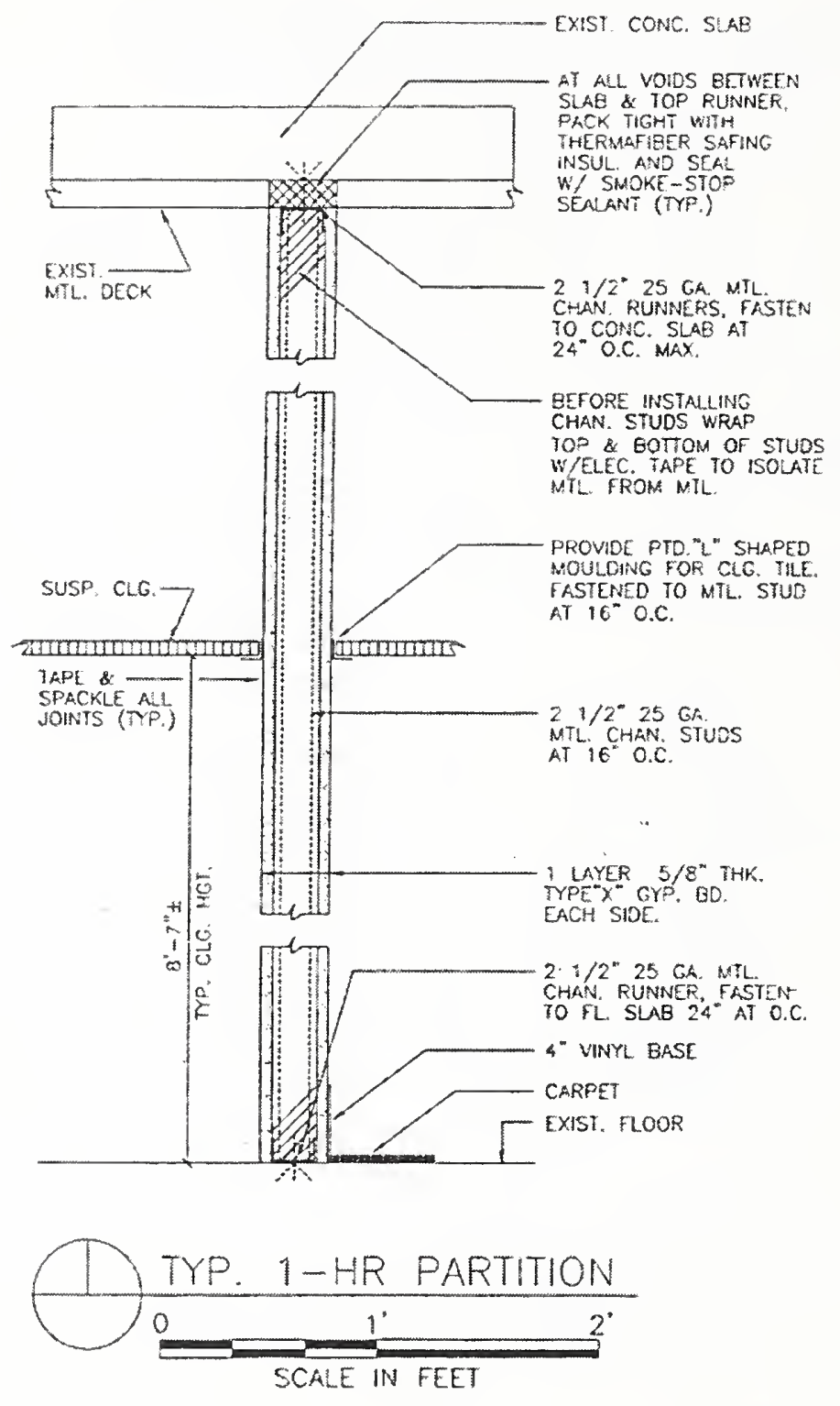

ARCH-O2 


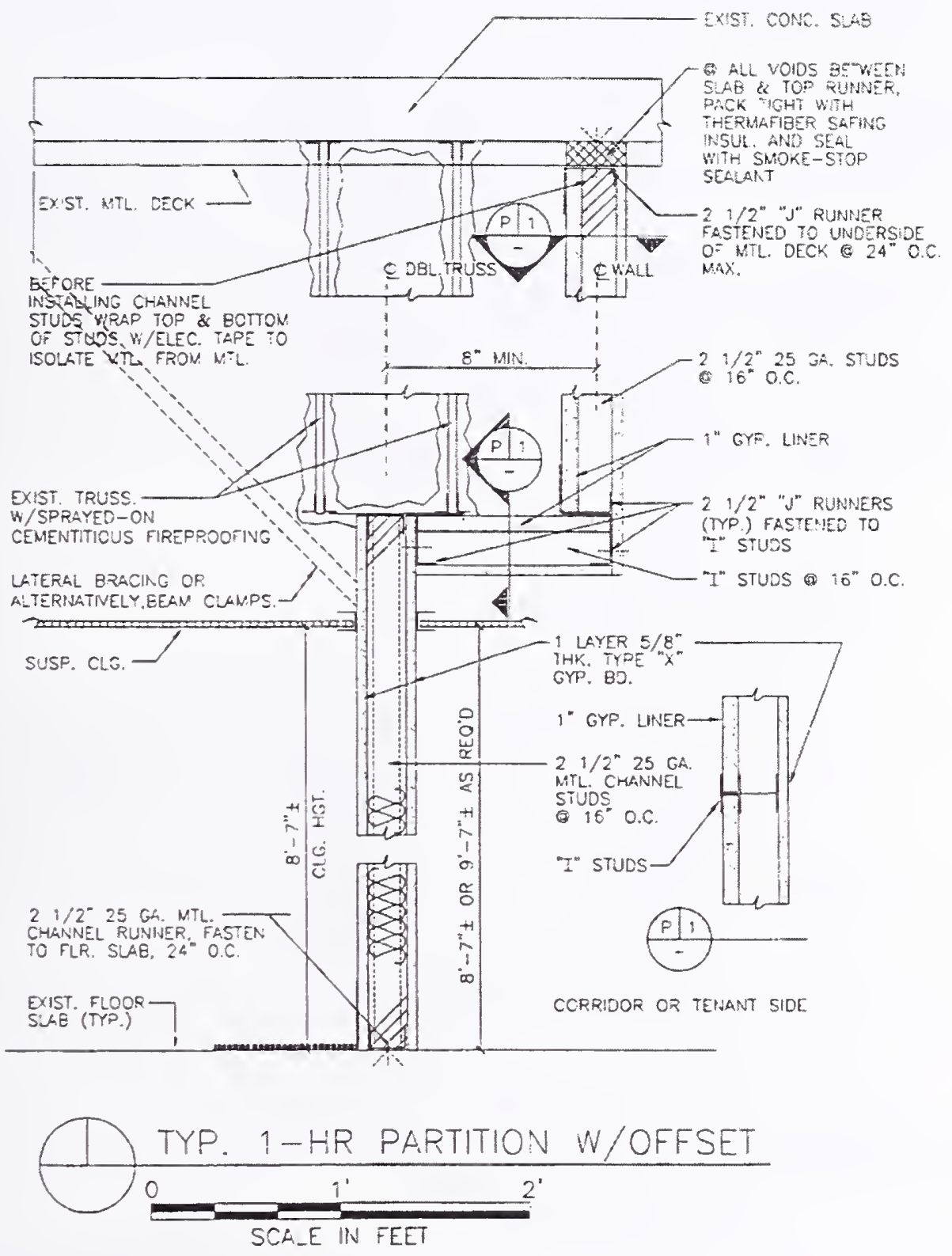

ARCH-03 


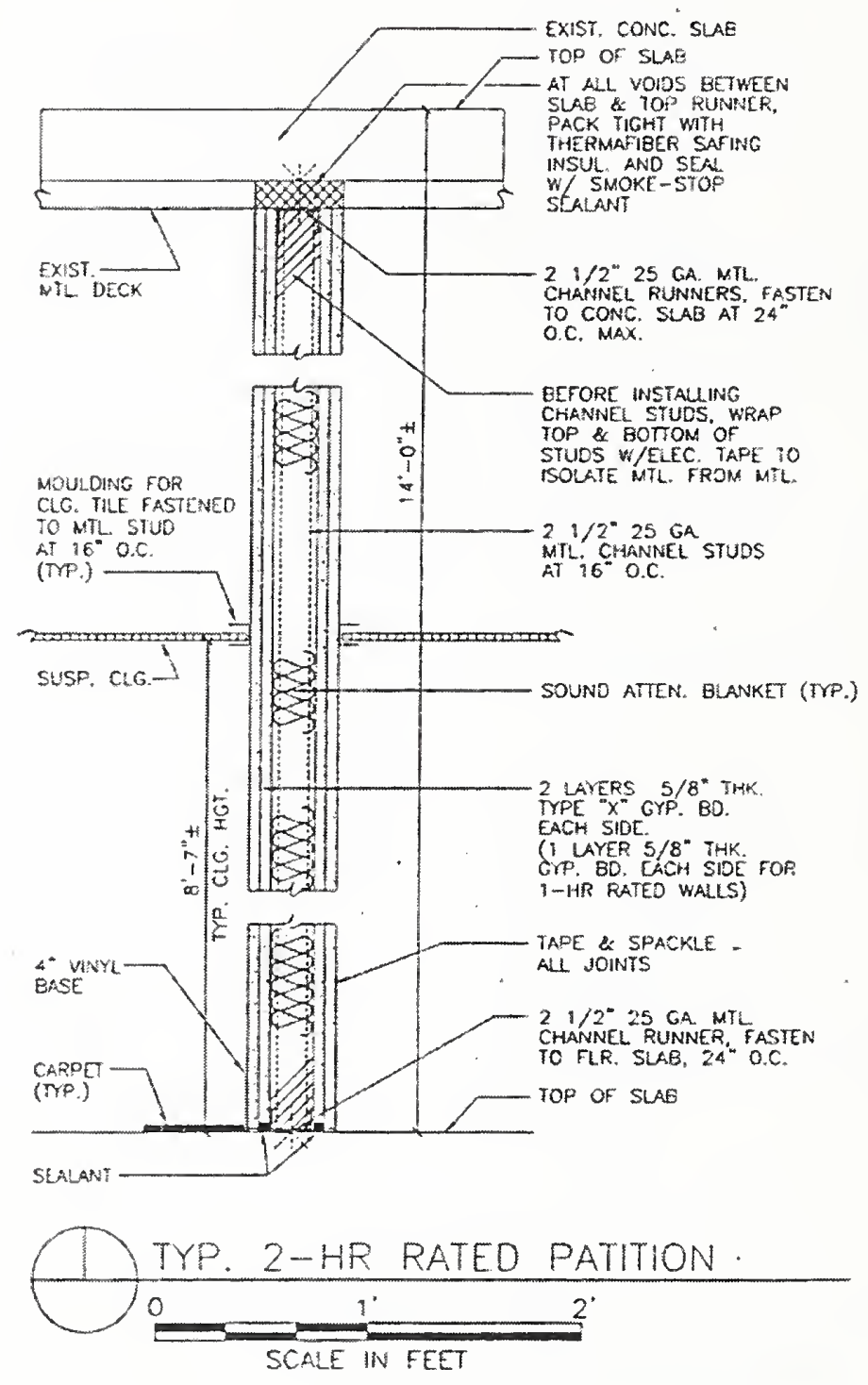

ARCH-04 

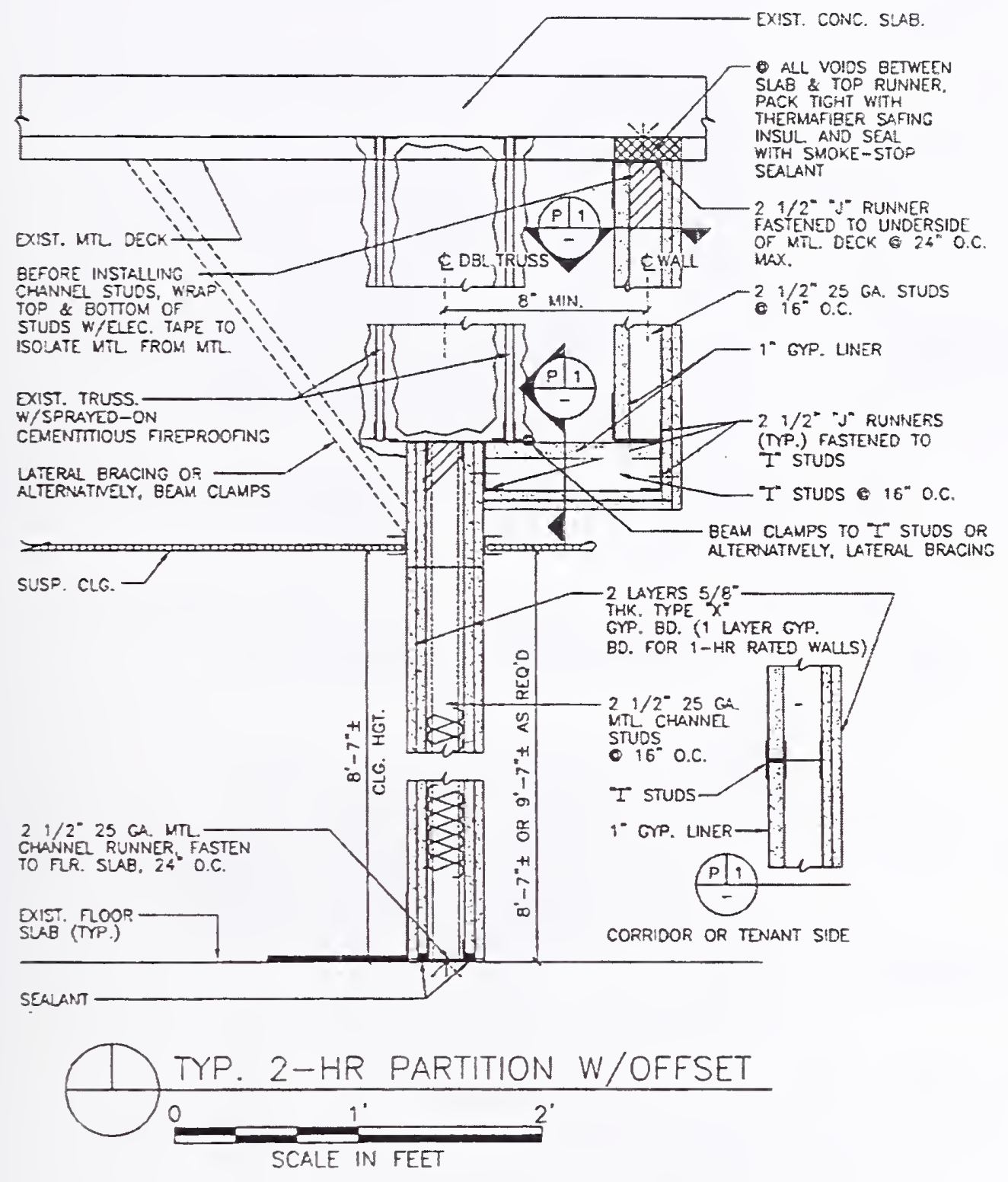

ARCH-05 

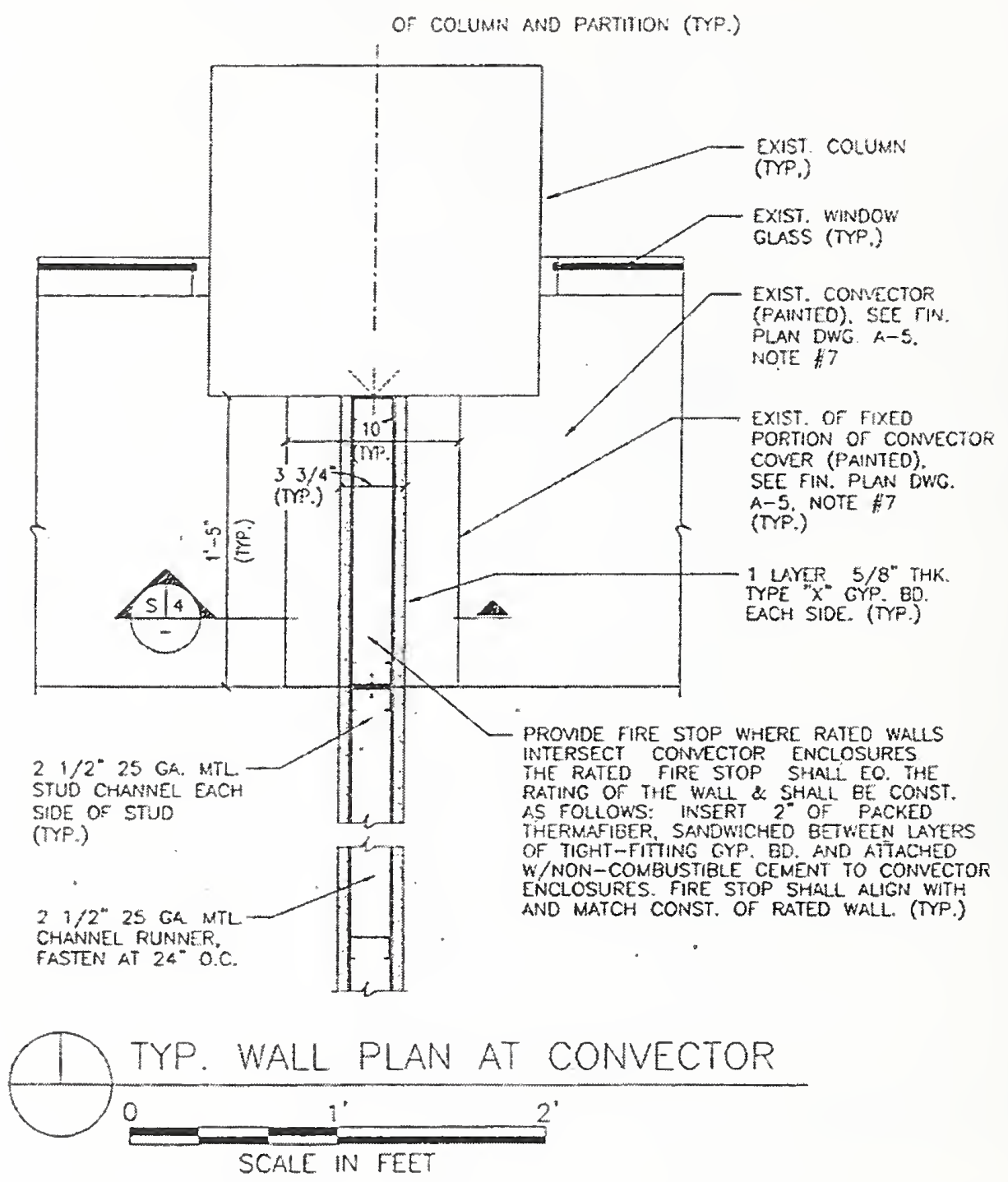

ARCH-06 


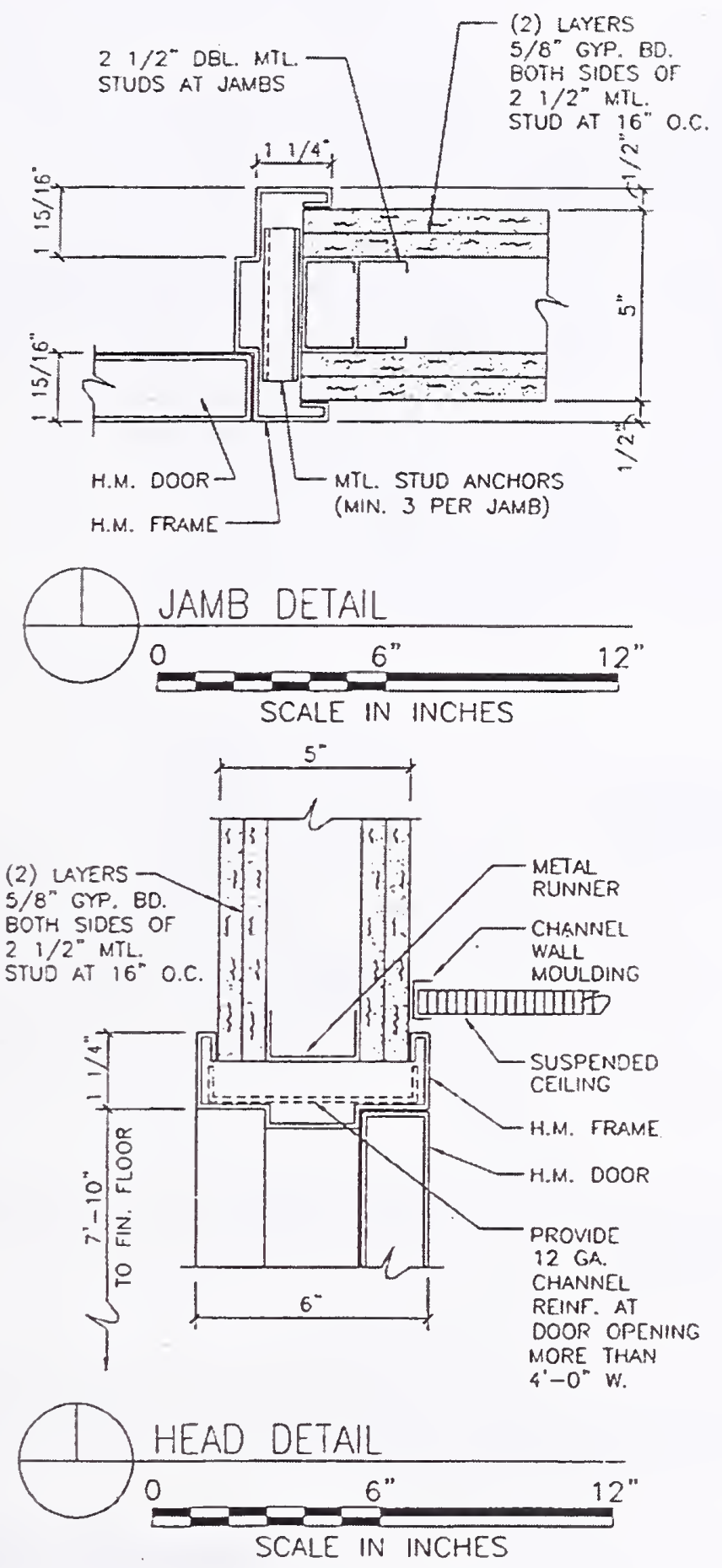

ARCH-07 

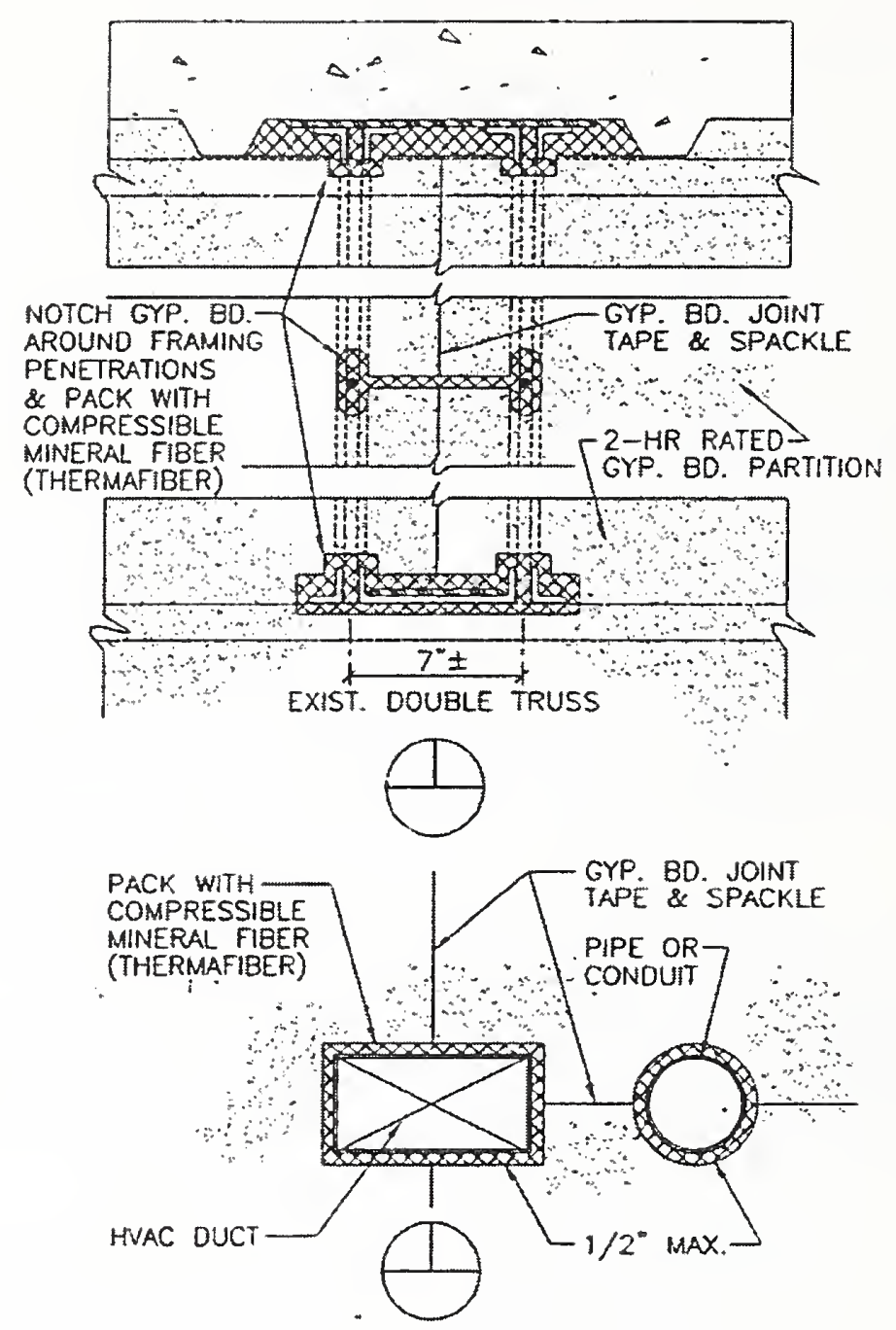

ELEVATION DETAILS OF

FIRESTOPPING OF TYP.

OPENING IN RATED

WALL ABOVE CEILING

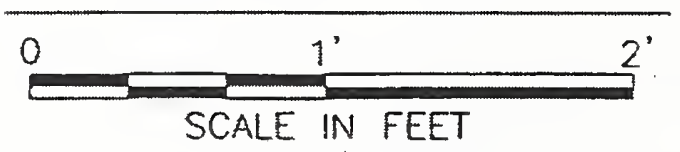

ARCH-08 


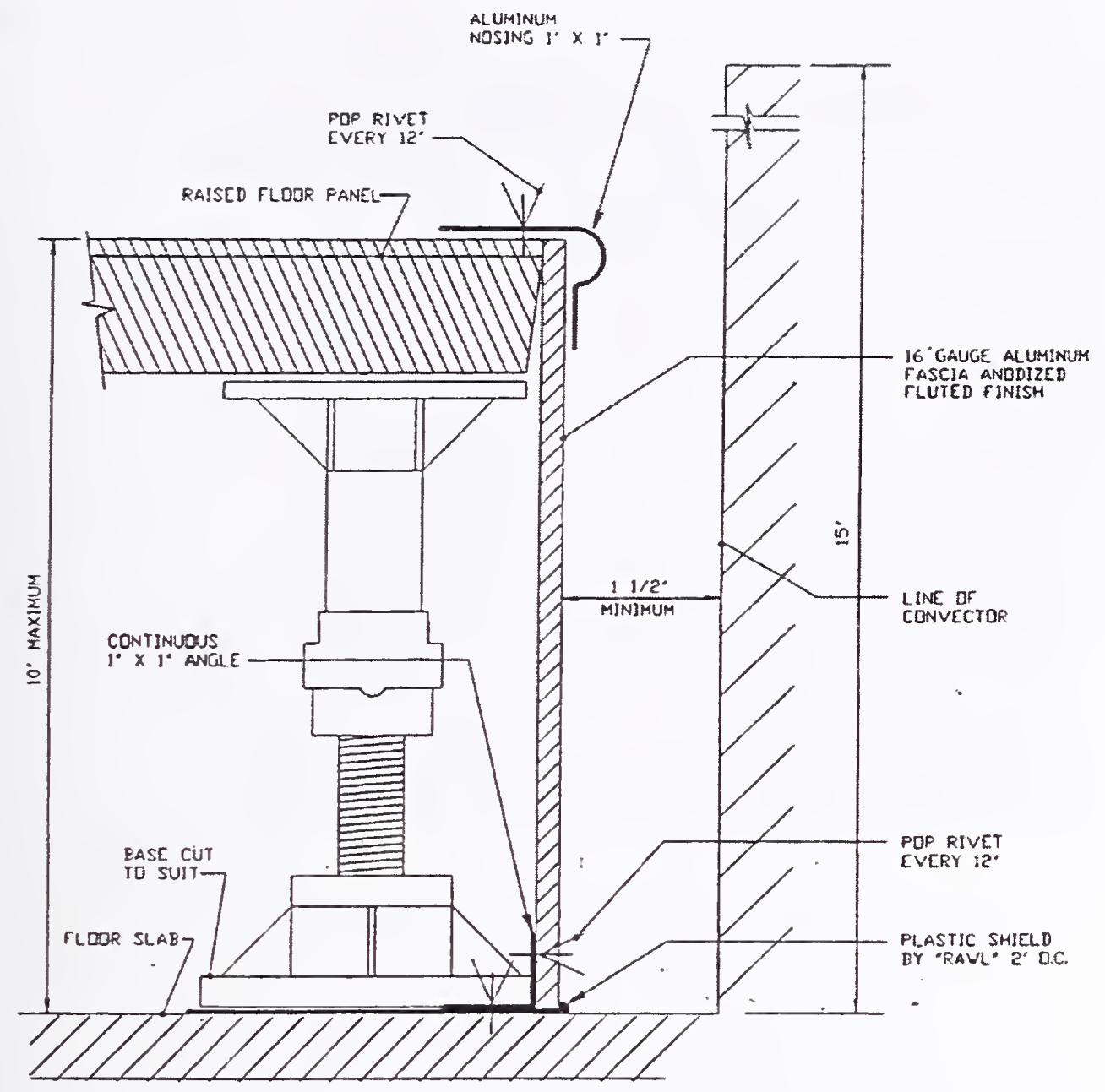

DETAIL DF RAISED FLOUR Q

PERIMETER INDUCTION UNITS

NOT TO SCALE

NOTE: ADDITIONAL FLODR GRILLS INSTALLED ON THE RAISED

FLDOR DIRECTLY IN FRDNT OF INDUCTION UNIT IS PEOUIRED

FOR THE EFFICIENT CIRCULATION OF AIR IN THE SPACE.

WTC - ARCH. 17 


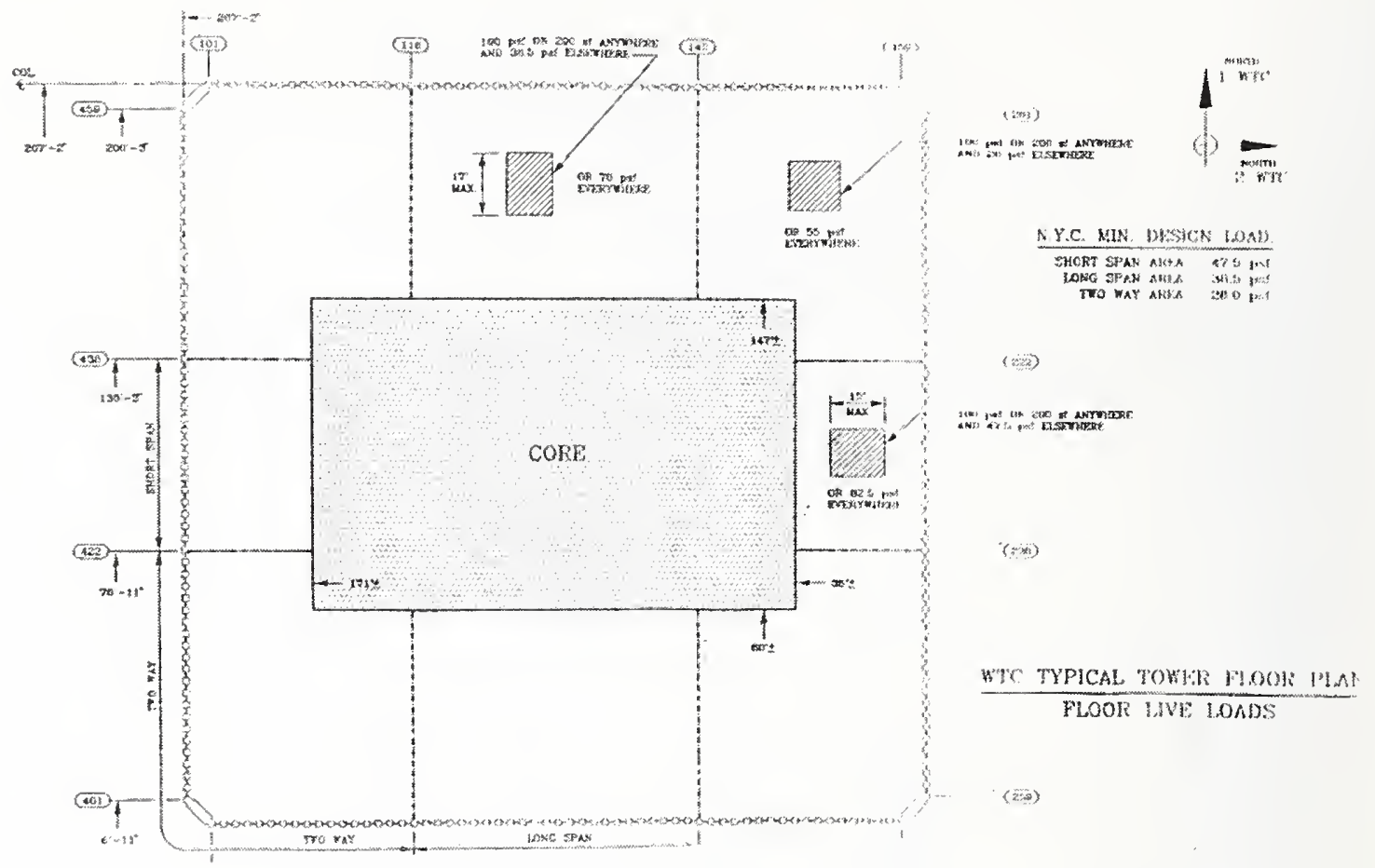

STR-01 


\section{DA Restricted Zones}

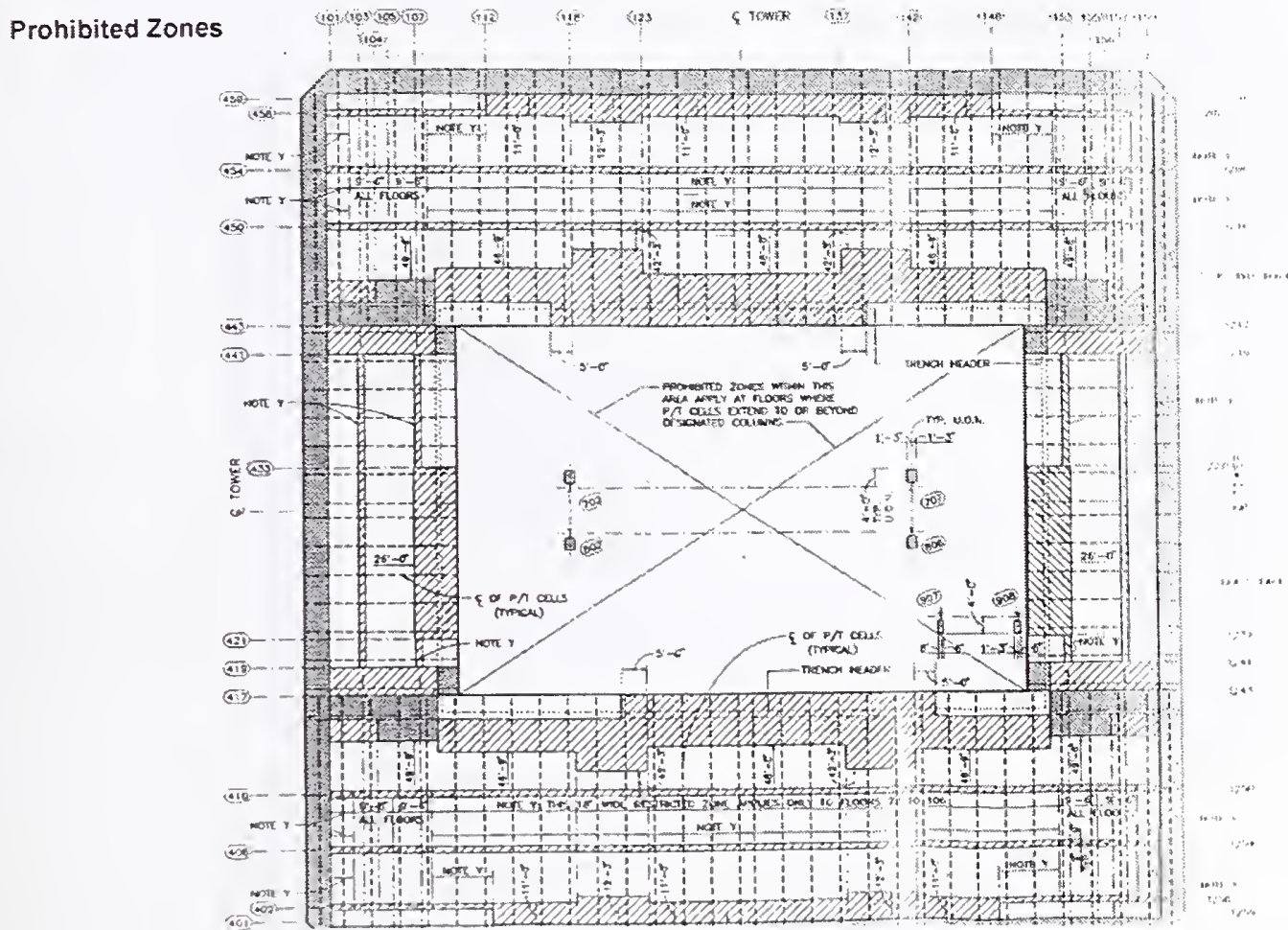

STR-02 
LEGEND
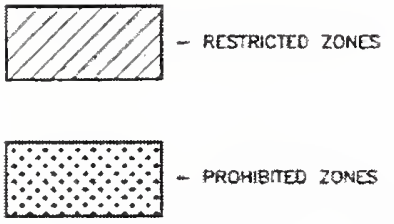

(SEE STRUCTUEA SPECIFCATIONS - SECTON A.)
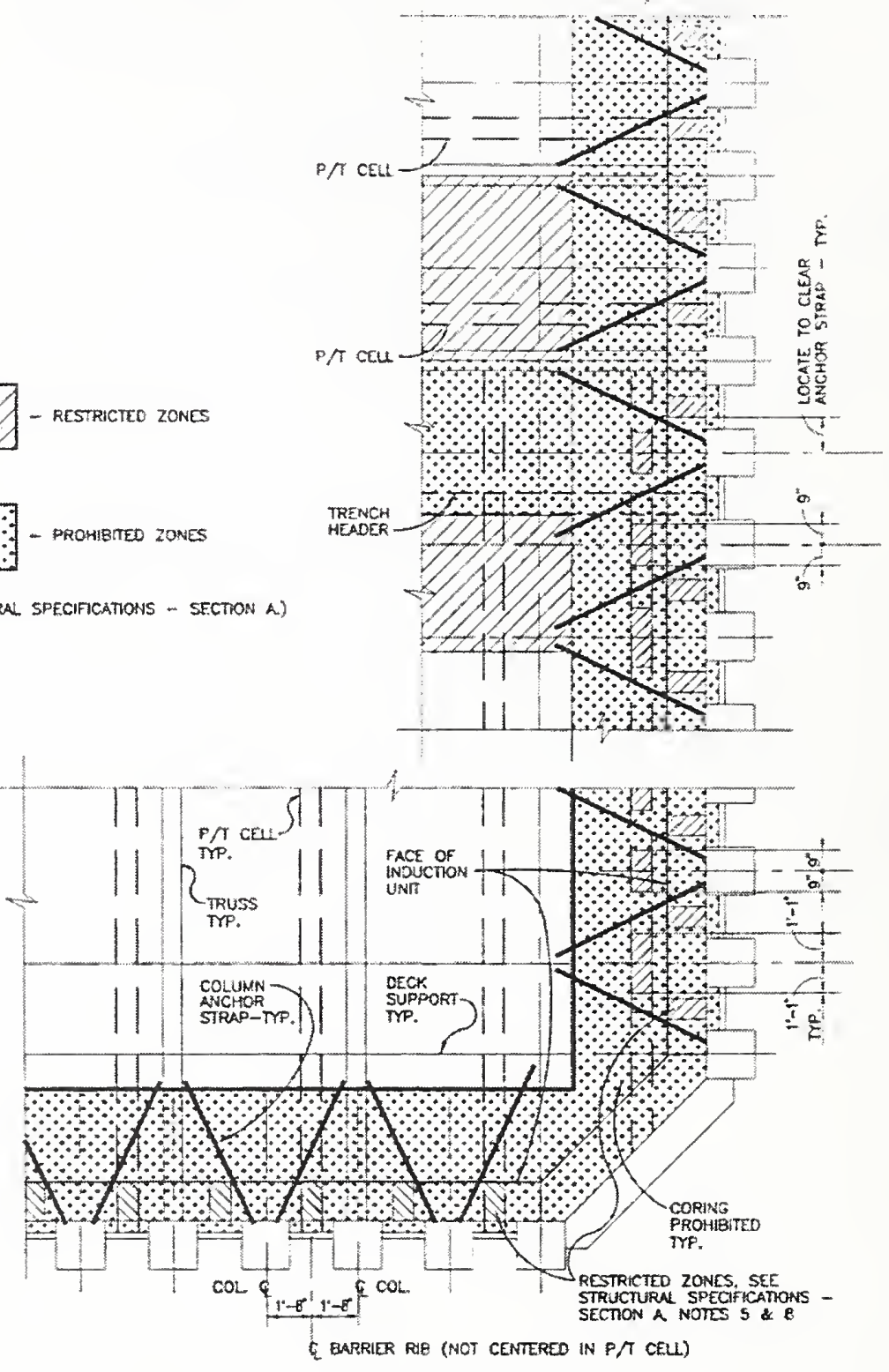

\section{DETAIL AT BUILDING PERIMETER CORING CRITERIA}

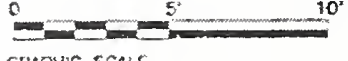

GRaphic scaie
STR-03 


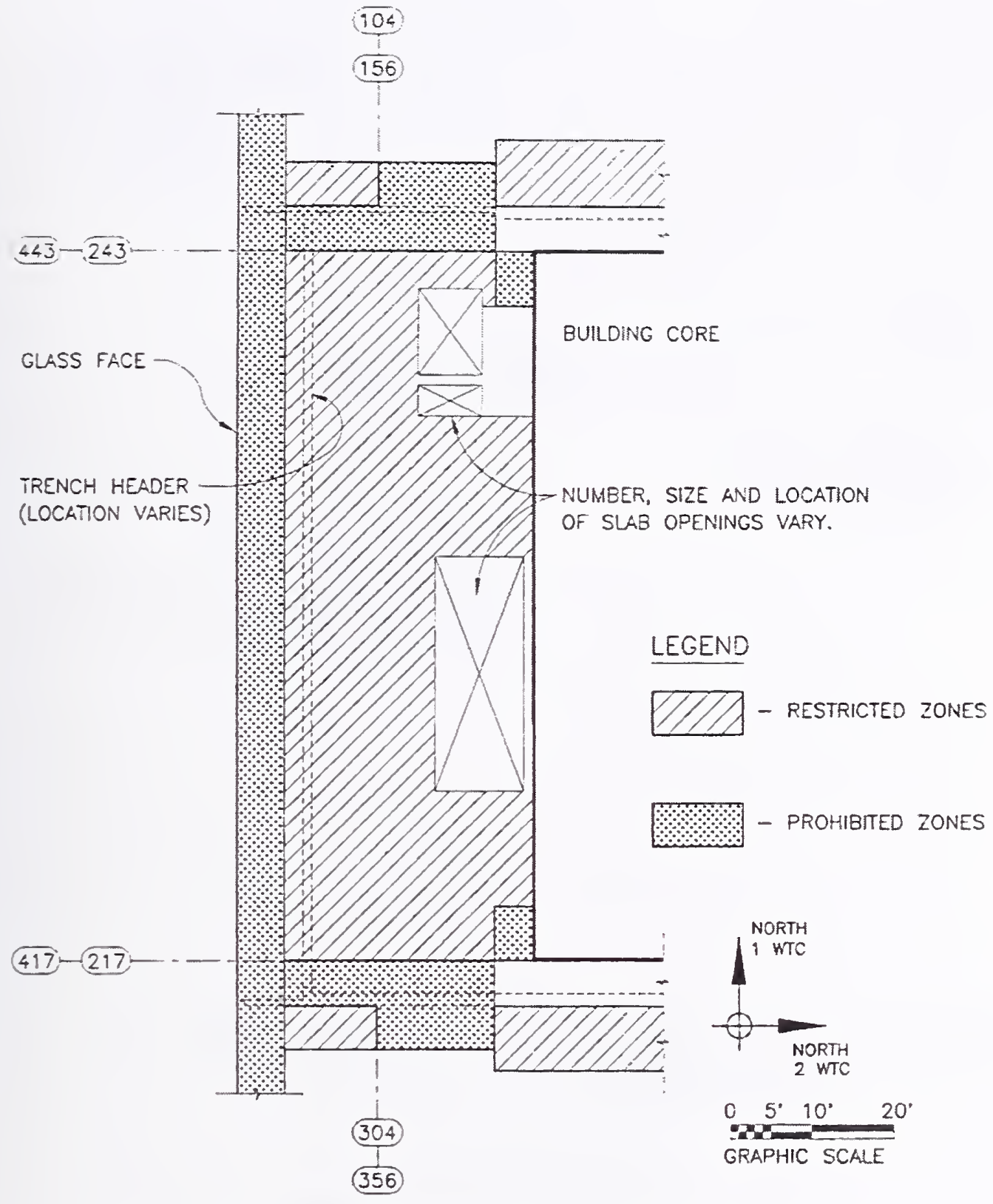

\section{PART. PLAN - FLOORS $45-48 \& 78-82$}

FOR BALANCE \& INFORMATION NOT SHOWN

SEE BASIC PLAN. PAGE STR-02

STR-04 


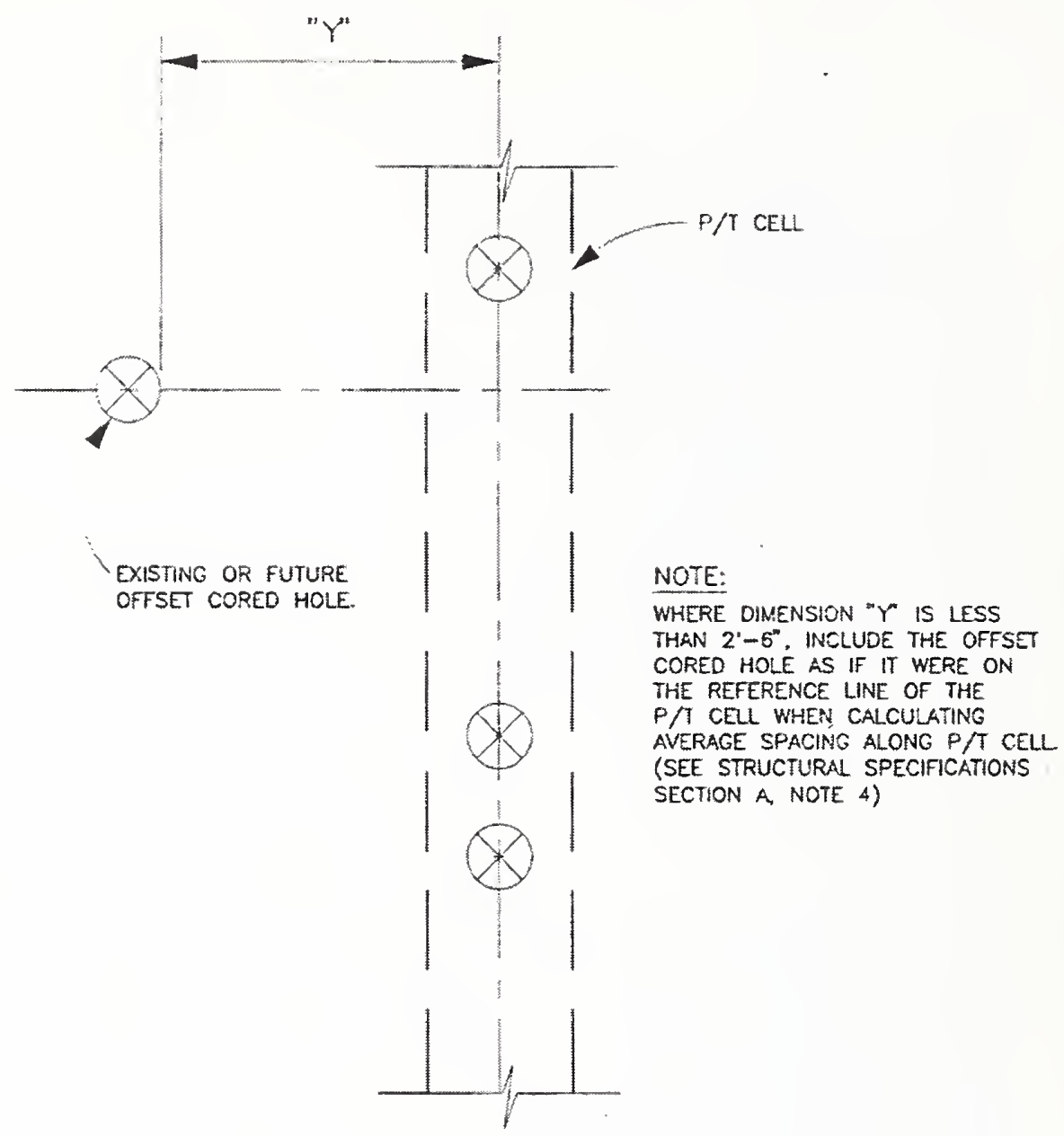

PLAN DETAIL OF SPACING CRITERIA AT OFFSET CORED HOLE

CORING CRITERIA

$$
\text { STR-05 }
$$


REMOVE CONCRETE BY

MEANS OF ELECTRIC HAMMER

AROUND EXISTING COREO

HOLE TO EXPCSE CUT

REBARS. RECAST SLAB

WITH NON-SHRINK GROUT.

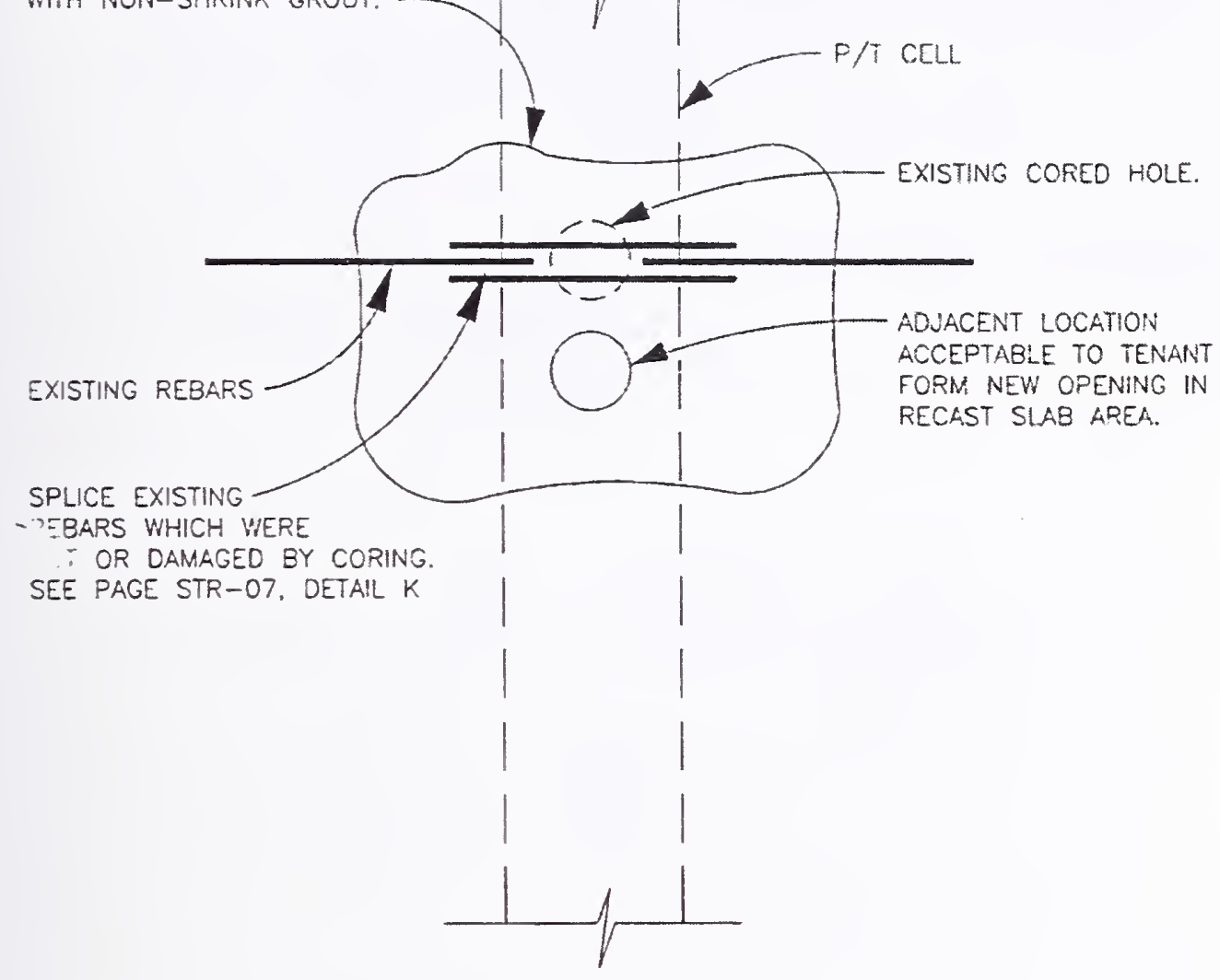

\section{REBAR SPLICE}

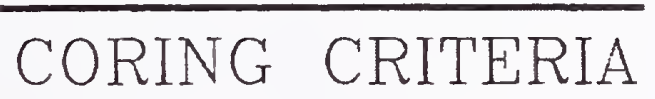

EXISTING HOLE, NOT PREVIOUSLY INSPECTED, INTENDED FOR RE-USE. ADJACENT LOCATION USED DUE TO NEED TO REPAIR CUT REBARS. 


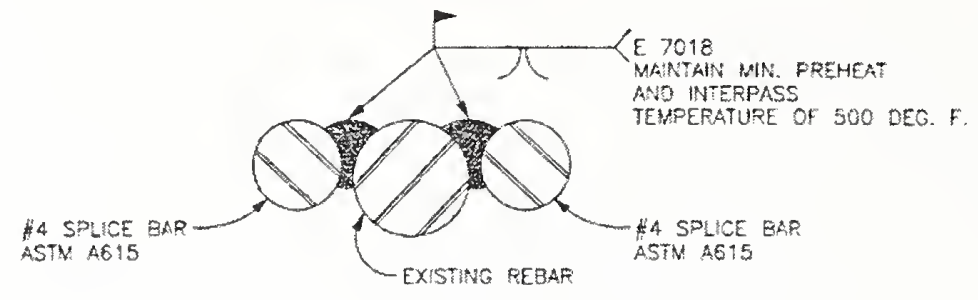

SECTION AT WELD

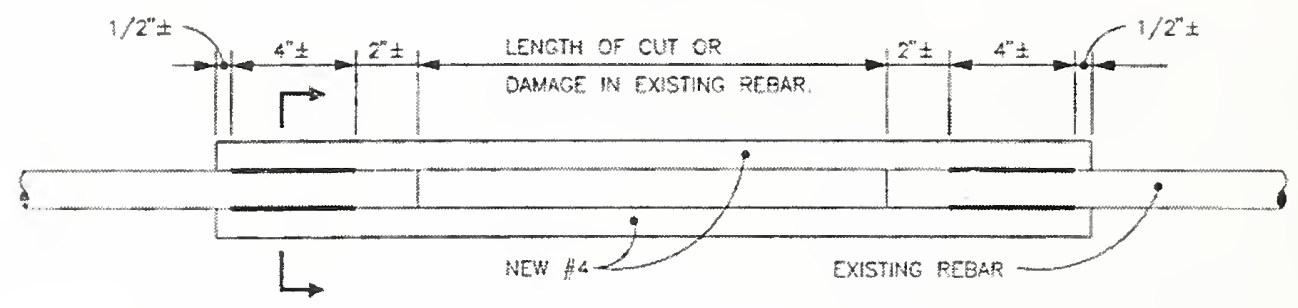

$\frac{\text { REBAR SPLICE }}{\text { CORING CRITERIA }}$

STR-Or 

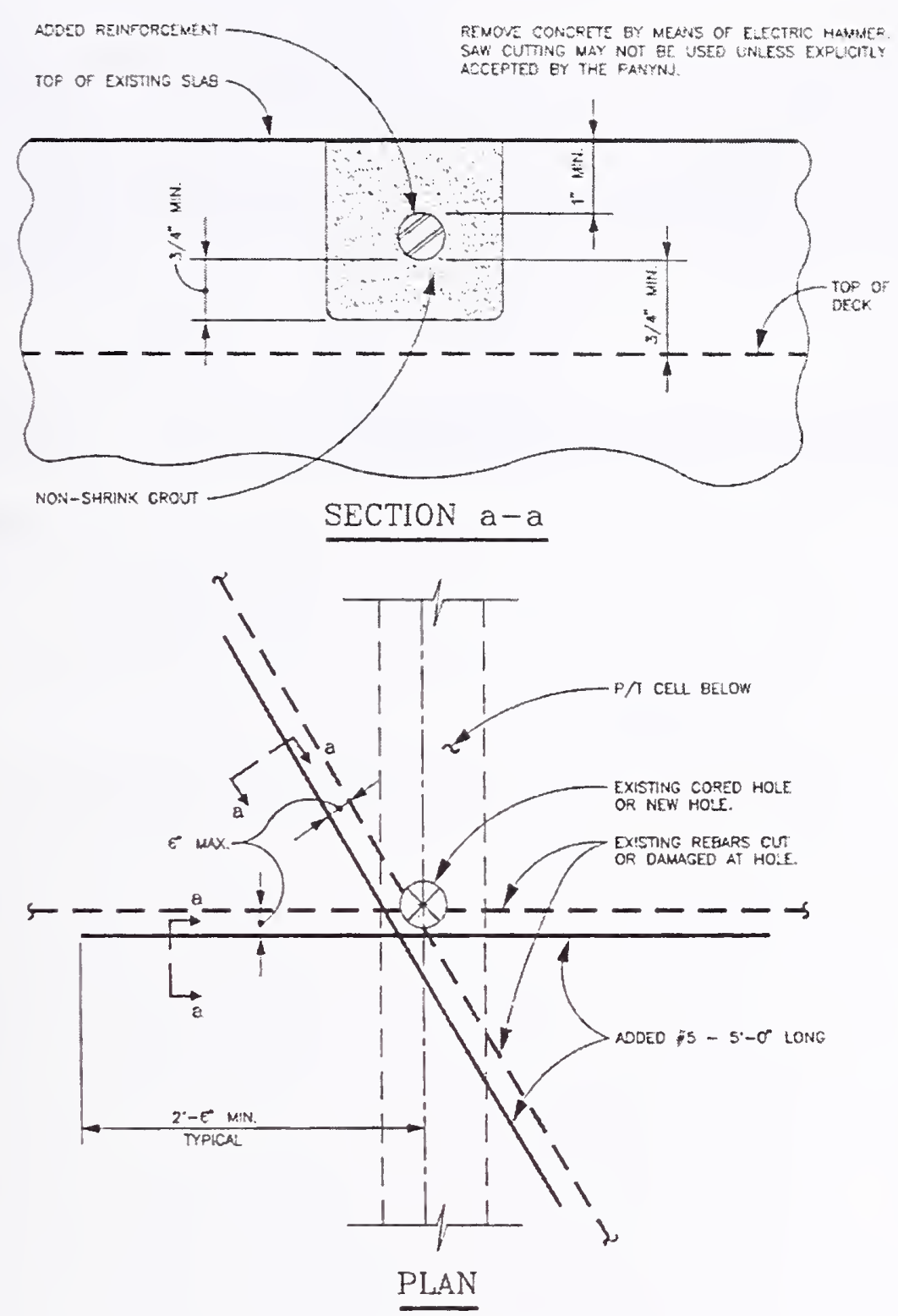

\section{$\frac{\text { REBAR REPAIR }}{\text { CORING CRITERIA }}$}

SCHENATIC REEAR REPAR DETALL WHERE HOLE CANNOT BE RELOCATED. THIS DCTAL TO BE USED ONEY WITH PRIOR APPROVAL, OT PANYNS. 


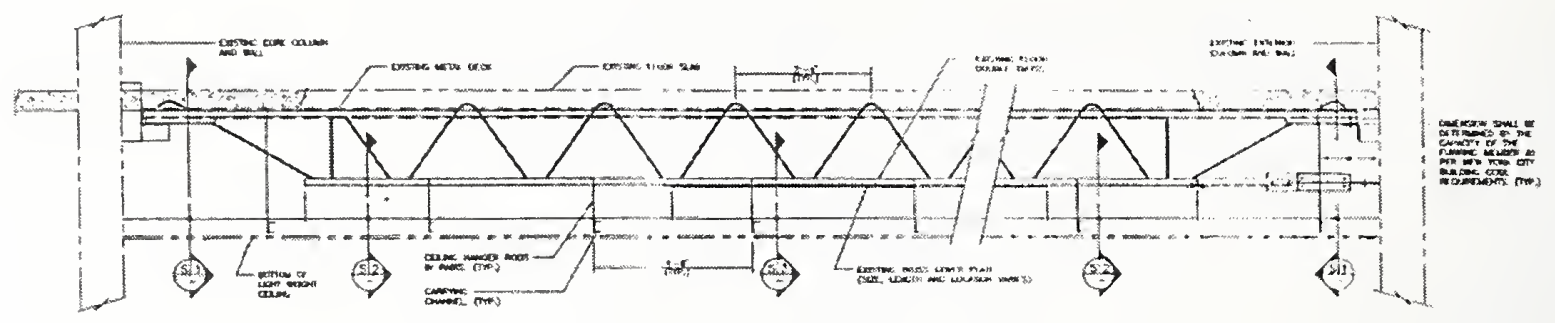

PART RLEYATHON - TYPICAL HOOR WTH DOUBLE TRUSS

LGHT KEIGHT CELLNG SUPPORT SYSTEM FOR FLOORS W/DOUBLI TRUSSES

STR -09 


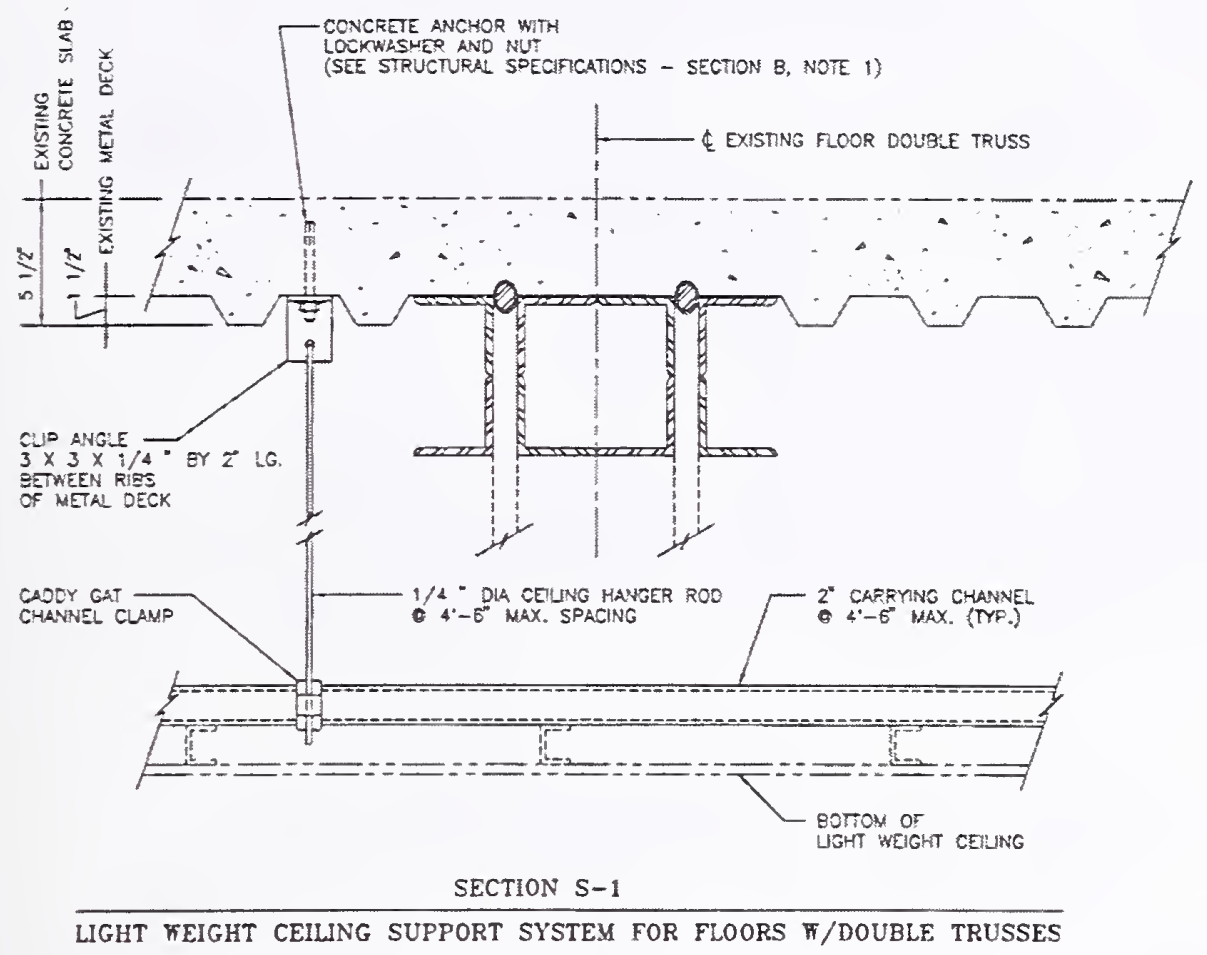

STR-10 


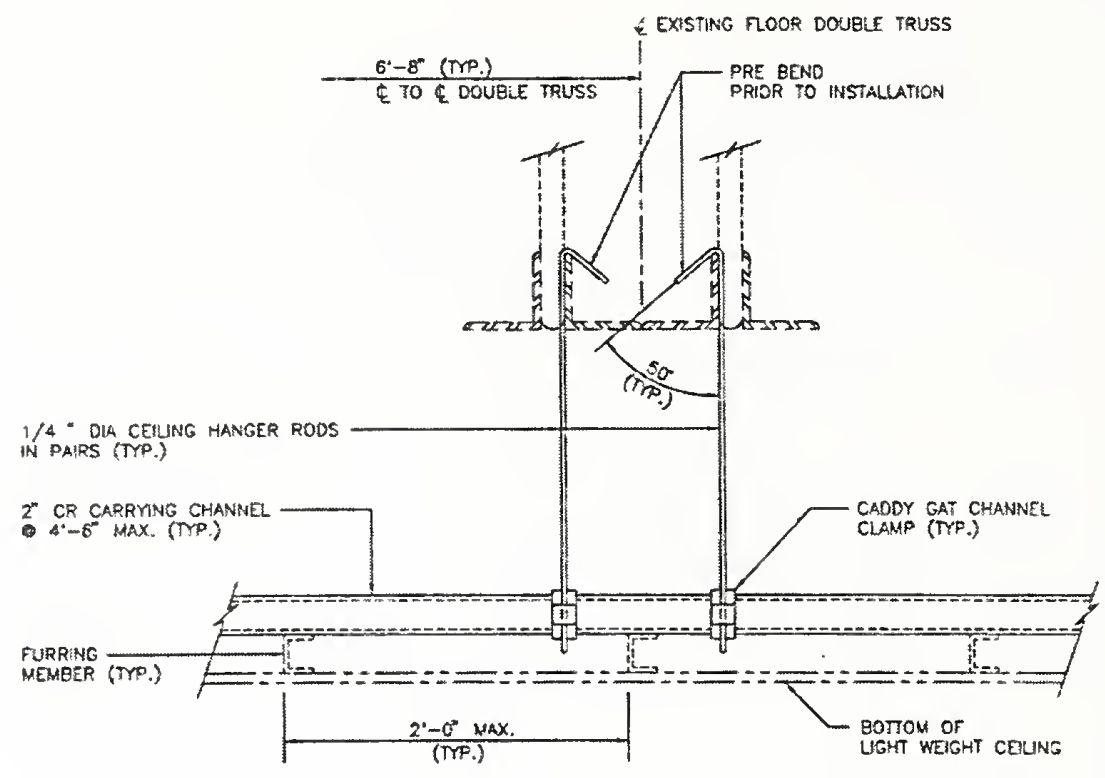

SECTION S-2

LIGHT HEIGHT CEILING SUPPORT SYSTEM FOR FLOORS $\$$ /DOUBLE TRUSSES

STR -11 


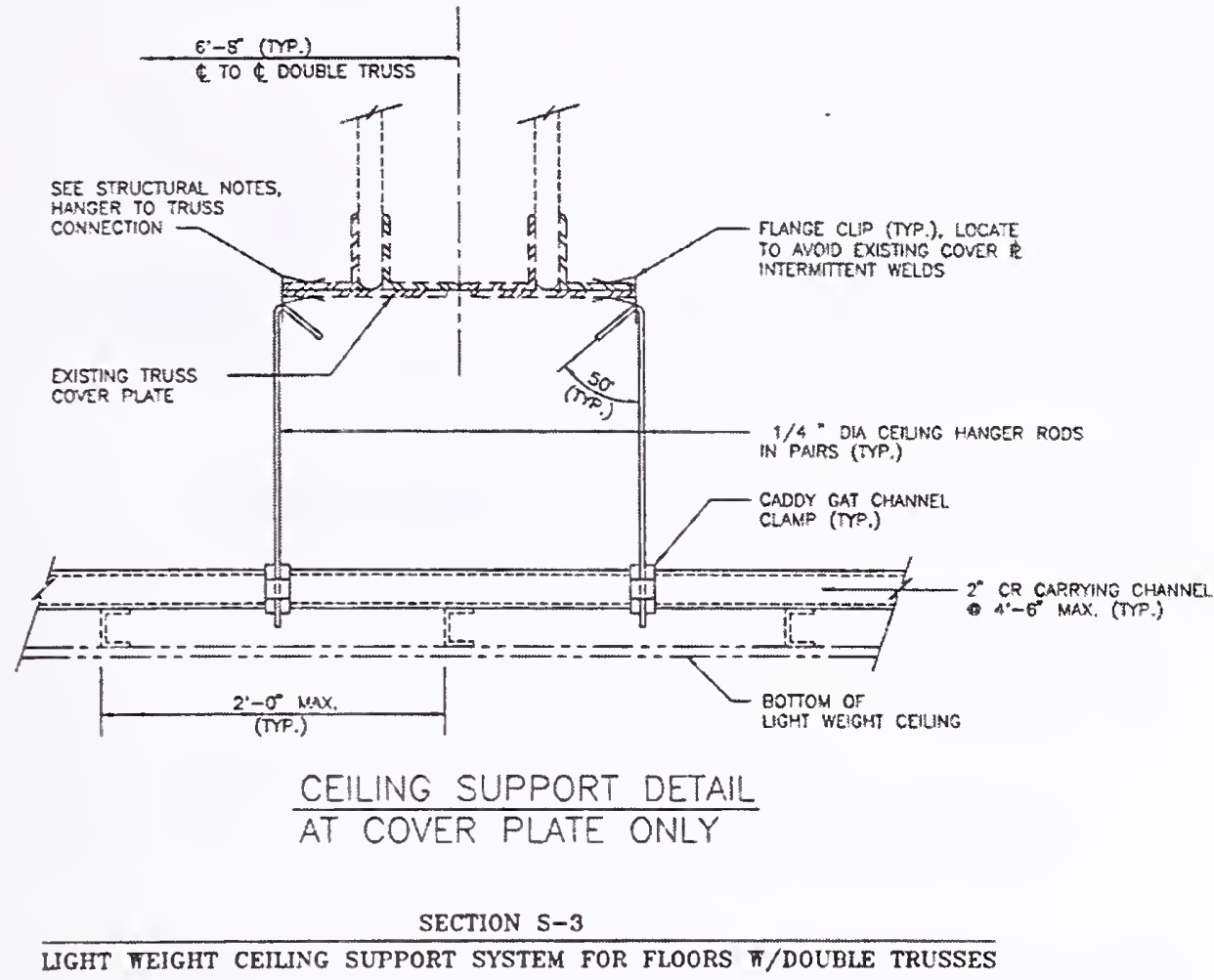

STR -12 


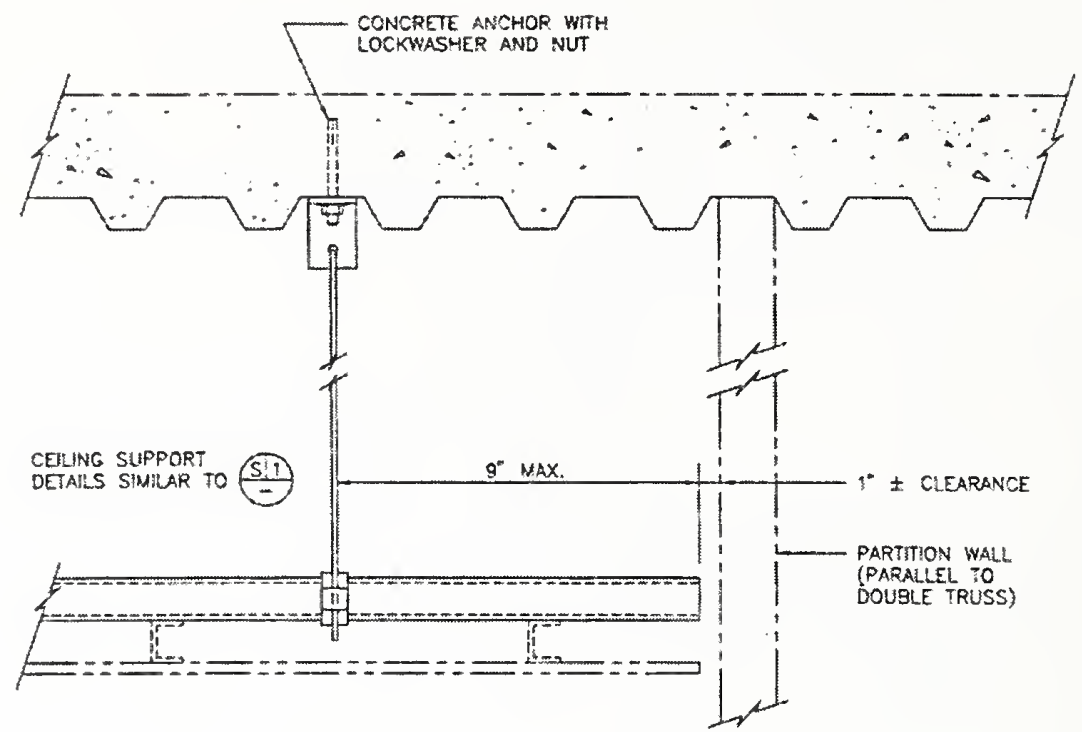

TYPICAL SECTION AT PARTITION WALL

TYPICAL SECTION AT PARTITION WALI.

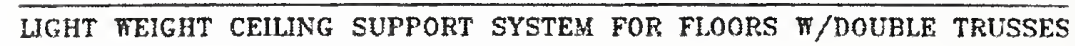

STR -13 


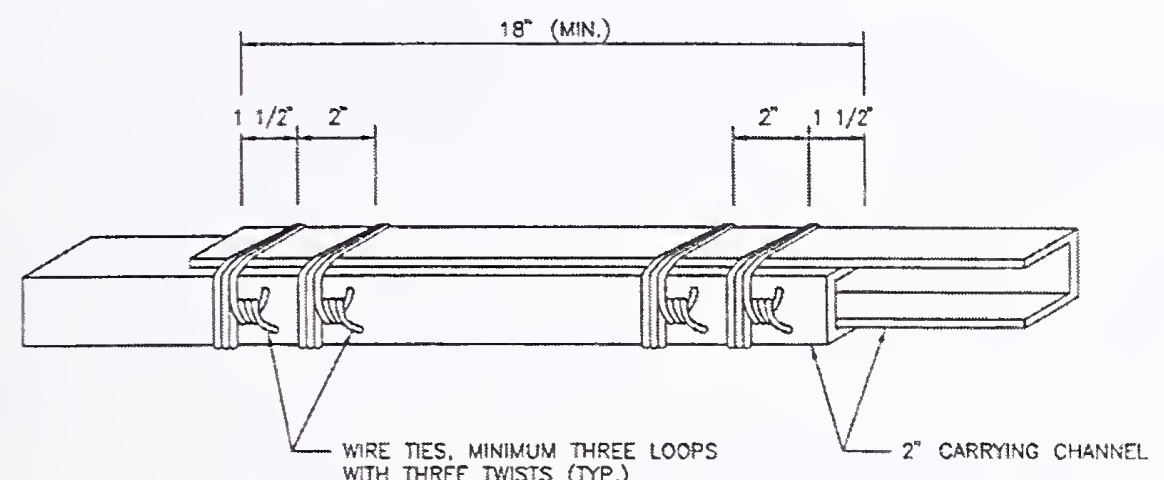
WITH THREE TWISTS (TPP.)

\section{TYPICAL "2" CHANNEL SPLICE DETAIL}

TYPICAL " $2 "$ CHANNEL SPICE DETAIL

LIGHT KEIGHT CEILING SUPPORT SYSTEM FOR FLOORS $\%$ /DOUBLE TRUSSES

STR-14 
This page intentionally left blank. 


\section{Appendix G \\ SUPPORTING DOCUMENTS}

This appendix contains the supporting documents that are referenced in this report. All of the documents contained in this appendix are reproduced with permission of The Port Authority of New York and New Jersey. Table G-1 contains a summary of supporting documents and their location within this appendix.

Table G-1. Supporting documents for report.

\begin{tabular}{|c|c|c|}
\hline \multicolumn{2}{|l|}{ Document Title } & $\operatorname{Page}(s)$ \\
\hline \multicolumn{3}{|c|}{ Section 2.1.4 - Tenant Constrnction Review Mannal (1997 Edition) } \\
\hline \multicolumn{2}{|c|}{$\begin{array}{l}\text { PANYNJ Memorandum dated August 8, } 1995 \text { from Oscar Suros, } \\
\text { Manager of the Engineering Department Quality Assurance } \\
\text { Division to Eugene J. Fasullo, Director and Chief Engineer }\end{array}$} & 300 \\
\hline \multicolumn{3}{|c|}{ Section 3.2.1 - Strnctural Integrity Inspection Progrann (Overview) } \\
\hline \multicolumn{2}{|c|}{$\begin{array}{l}\text { Letter dated January 12, } 1990 \text { from Saw-Teen See of Leslie E. } \\
\text { Robertson Associates to Suren Batra of the Port Authority of New } \\
\text { York and New Jersey (WTCl-123-P) }\end{array}$} & 304 \\
\hline \multicolumn{3}{|c|}{ Section 3.2.2 - Sunnuary of Structural Integrity Inspection Program Reports } \\
\hline \multirow{5}{*}{$\begin{array}{l}\text { Locations of columns inspected in Accessible } \\
\text { Columns Structural Integrity Inspection reports }\end{array}$} & 1993 report & 306 \\
\hline & 1995 report & 307 \\
\hline & 1996 report & 311 \\
\hline & 1997 report & 319 \\
\hline & 1998 report & 328 \\
\hline \multicolumn{2}{|c|}{$\begin{array}{l}\text { Historical Review of World Trade Center Damping Units } \\
\text { (WTCl-230-L) }\end{array}$} & 336 \\
\hline
\end{tabular}




\title{
PANYNJ Memorandum dated August 8, 1995
}

\author{
THE PORT AUTHORITY OF NY \& NJ
}

MEMORANDUM

TO: $\quad$ Eugene J. Fasullo, P.E., Director of Engineering \& Chief Engineer

FROM: Oscar Suros

DATE: $\quad$ August 8, 1995

SUBIECT: SEISMIC DESIGN - NEW YORK CITY BUILDING CODE

COPY TO: A. Aronowitz, A. Brociner, J. Buchsbaum, R. Davidson, J. Englot, J. Kelly, T. Kelly, F. Lombardi, E. Ramabhushanam, EPMs

REF: Memo, Vanacore to Directors, October 4, 1988 and Memo. Suros to Fasullo, lune 7,1994 THE PORT AUTHORIT OF NY \& QUALITY ASSURANCE DEV. ENONFEPING DEPT.

$$
4 \mathrm{Ub}: 1995
$$

NOTED:

\section{RECEIVED}

As established by the referenced memorandarptaks toen our palicy 10 design building structures and building components for seismic effects in both New Jersey and New York using the BOCA National Building Code. Recently the New York City Council and the Mayor enacted Local Law \#17/95 providing requirements for seismic design of buildings and their components. This law adds provisions to the New York City Building Code that will be mandatory for all building or alteration applications filed on or after February $21,1996$.

Your approval is requested to start using the recenty enacted change ste the New York City Building Code for all construction in New York City, indudin RP the revisions listed in Attachment A, effective immediately. The BOCA National IB Building Code will continue to be used for New Jersey and Yonkers construction.

The revisions in Attachment $A$ are required in order to meet the stade $P$ intent of the seismic revisions to the New York City Building Code. This will insfrgh that potential overhead hazards will not fall on building occupants as a result of a IR

\begin{tabular}{l}
\hline IR \\
\hline AT \\
\hline MA \\
\hline CK \\
\hline FILE \\
\hline POST \\
\hline
\end{tabular}


E.J. Fasullo, P.E.
August 8, 1995

seismic event and that the building can be safely cyacuated during and immediately following a seismic event. Similar provisions are included in the BOCA Code and are considered minimum requirements. No significant cost penalty is estimated due to the minor modifications included in Attachment A.

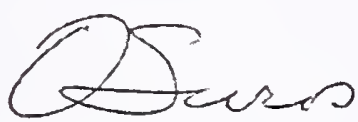

Oscar Suros, P.E.

Manager

E/A Design Division

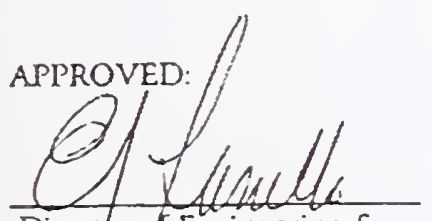

Director of Engineering \&

Chief Enfoineer

Altachments

OS:cep 
ATTACHMENT A

Revisions to the Ney York City Building Code

Revise Table No. 23-p of RS 9-6 by:

(a) Adding after II. I. b.

"c. Overhead Signs _........ 2.00";

(b) Adding after II. 3 .

"4. Anchorage for suspended ceilings weighing more than 4 psf

without the veight of light fixtures... $0.75^{n}$;

(c) Adding after III. 1.

"2. Elevator and counterveight guardrails and supports . . 1.25"

"3. Sprinkler piping ${ }^{5}$........ 2.00"

"4. Gas and high hazard piping. ..... 2.00"

"5. Other piping ${ }^{6}$........ 0.67 ".

"6. HVAC ducts ${ }^{6}$....... $0.67^{\text {" }}$

(d) Adding the following notes after note 4. at the bottom of the table:

"5. The design of seismic restraints for sprinkler piping in compliance ith NFPA 13 using a design acceleration of 0.15 is acceptable in lieu of compliance with these provisions.

6. Seiswic restraints are not required for any of the following conditions for other pipe systens or EVAC ducts:

1. Piping or ducts suspended by individual hangers 12 inches or less in length from the top of the pipe or duct to the supporting structure.

2. Piping in boiler and wechanical rooms vhich has less than $11 / 4$ inches inside diameter.

3. Piping in other areas which has less than $21 / 2$ inches inside diameter.

4. Ducts which have a cross-section area less than 6 square feet." 
Table No. 23-P

HORIZONTAL FORCE FACTOR $C_{\Omega}^{\prime}$

\begin{tabular}{|c|c|}
\hline $\begin{array}{c}\text { ELEMENTS OF STRUCTURES, NONSTRUCTURAL } \\
\text { COMPONENTS AND EQUIPMENT } \\
\end{array}$ & $\begin{array}{l}\text { VALUE } \\
\text { OF } C_{e}\end{array}$ \\
\hline 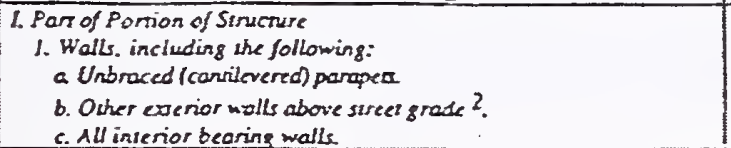 & $\begin{array}{l}2.00 \\
0.75 \\
0.75\end{array}$ \\
\hline 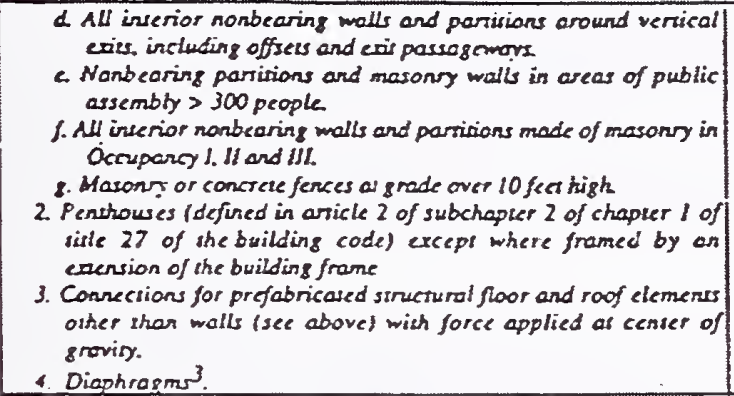 & $\begin{array}{c}0.75 \\
0.75 \\
0.75 \\
0.50 \\
0.75\end{array}$ \\
\hline 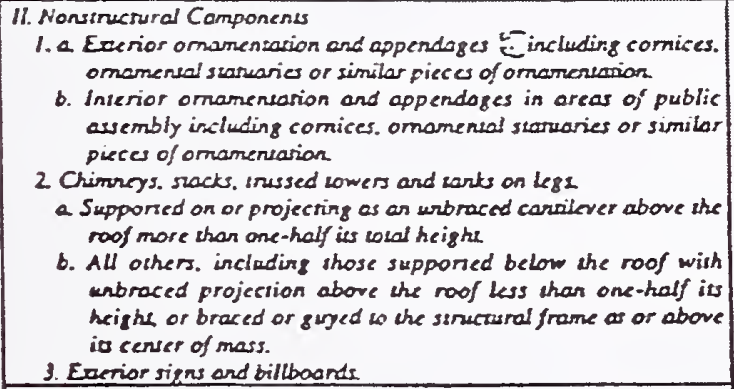 & $\begin{array}{l}0.75 \\
200 \\
\end{array}$ \\
\hline 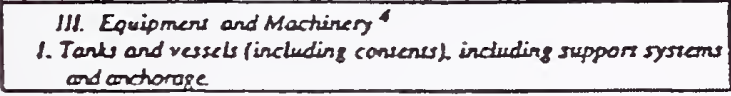 & 0.75 \\
\hline
\end{tabular}

Nores:

1. See Secrion 231218$)^{2}$ for addirional requiremeno for determining $C_{p}$ for nonrigid

equipment of for isons supponed ar or below srade

2 Sec Section $2312(\mathrm{~h}) 2 \mathrm{D}(\mathrm{iat})$ and Secrion $2313(8) 2$.

3. See Secrion $2312(h) 21$.

4. Equipmens and machirery include such isems as pumps for fure sprintlers. molors

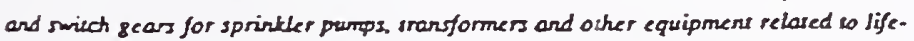
safery including consrol parels, major condwit duaing and piping serving such equipment and mactinery. 


\title{
Letter dated January 12, 1990 from Saw-Teen See of Leslie E. Robertson Associates to Suren
} Batra of the Port Authority of New York and New Jersey (WTCl-123-P)

\author{
LESLIE E. ROBERTSON ASSOCIATES Consulting Siruciurel Engireer!

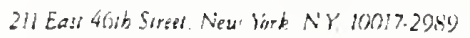 \\ Phone $(212) 750.000(1)$ \\ 12 January 1990 \\ Fax. (2)23 ? $79(2)(0) 2$ \\ Eile: B1003900 \\ Mr. Suren Batra \\ The Port Authority of New York \& New Jersey \\ WhC Planning \& Design Department \\ one world Frade Center - 74 South \\ New York, NY 10048 \\ via messenger \\ Reference: The world Trade Center Facilities: \\ Structural Integrity Inspections \\ Gentlemen: \\ We are pleased to submit our proposal to monitor the structural \\ integrity of the physical facilities of The worid Trade center \\ complex.
}

\section{Experience}

Over the past 20 plus years, we at LERA have gained unparalleled insiahts into the structural behavior of the Forld Trade center complex. We believe that the continuity of experience with the project which the engineers of our $f i x m$ have provides us an extensive, accessible base of knowledge about these structures unmatched anywhere else.

in 1986, we provided to you an action plan of testing and inspecticn. so as to assure the continued long term structural integrity of the complex.

\section{Economy}

Although we were not charged with carrying out this pian, our cesigris for building renovation have impacted the testing and inspection actlvities which have been uncertaken. For example, we have recently reccmmended that planned renovation projects be used to access Plaza level tower columns for inspection rather than incurring the high cost of removing exterior column covers especially for inspection.

Many examples occur wherein economies can be attained through coordination of renovation, operations and inspection activities. Ever tenant renovations, many of which we engineer, offer such opportunitles. And because of the smal: number of people within our Eirm who would accomplish both the renovation and inspection work, coordination is an easy matter. 


\section{LESLIE E. ROBERTSON ASSOCIATES}

Mr. Suren Batra $\quad$-3- 12 January 1990

\section{Other Sacilities}

This proposal addresses the monitoring of the structural integrity of the buildings that comprise the world Trade center complex only. Moritoring of the structural integrity of the PANYNU's Bathgate and Yonkers Industrial Parks, and Hoboken Piezs, has not been included as part of this proposal. However, we would be pleasec to prepare a similar detailed proposal for the inspecion of these facilities.

We are mest appreciative of this furthe opportunity to work with the ?AXYiu and we hope for your favorable response.

Very truly yours,

LESZIE E. ROBERTSON ASSOCZATES

sout Ten Sea

Saw-Teen see

Hive/D:0

Enclosure

XJF, LER, RZ, DAS, EAC 


\section{Locations of Columns Inspected in Accessible Columns Structural Integritv Inspection Reports}

1993 Accessible Columns SII Report (part of WTCI-66-L)

\section{LERA}

HORZD TRADE CENTER

Structural integrity inspection

Accessible columis o $1,2,4$ and 5 wro
P1203904ஷ3927

29 January 1993

Page 6 of 9

TABLE A

\begin{tabular}{|c|c|c|c|c|}
\hline Tover & $\begin{array}{c}\text { El avator } \\
\text { Shaft Number }\end{array}$ & $\begin{array}{c}\text { I100ra } \\
\text { Irspected }\end{array}$ & $\begin{array}{l}\text { Adjacent } \\
\text { Column Number }\end{array}$ & $\begin{array}{c}\text { Tace of Colum } \\
\text { Inspocted }\end{array}$ \\
\hline \multirow[t]{10}{*}{$\left(\begin{array}{ll} & A \\
\text { WTC }\end{array}\right)$} & 21 & $3-78$ & 606 & East \\
\hline & & $4-73$ & 607 & West \\
\hline & 36 & $1-32$ & 702 & East, South \\
\hline & & $1-32$ & $80:$ & East, North \\
\hline & 63 & $45-67$ & 701 & East, South \\
\hline & & $45-67$ & 802 & East, North \\
\hline & 73 & $43-74$ & 703 & North, West \\
\hline & & $43-34$ & 803 & North. west \\
\hline & 83 & $78-93$ & 701 & East, South \\
\hline & & $78-93$ & 801 & East, North \\
\hline \multirow[t]{8}{*}{$\begin{array}{l}\mathrm{B} \\
(2 \mathrm{WTC})\end{array}$} & 15 & $4-78$ & 602 & Sorth \\
\hline & & $4-78$ & 603 & South, hest \\
\hline & 29 & $1-16$ & 707 & South, East \\
\hline & & $1-16$ & 806 & South, west \\
\hline & 56 & $45-54$ & 707 & South, East \\
\hline & & $45-54$ & 806 & South, Nest \\
\hline & 78 & $78-86$ & 707 & Sourh, East \\
\hline & & $78-86$ & 806 & South, West \\
\hline $\begin{array}{l}\text { Northeast } \\
\text { plaza } \\
\text { (5 wTC) }\end{array}$ & $\frac{5-7}{28}$ & $2-9$ & $\frac{E-7}{28}$ & i \\
\hline
\end{tabular}

see Appendix A for the plan locations of the above columns. 
- 1995 Accessible Columns SII Report (part of WTCI-66-L)

LERA

14 Apri: 1995

File: 1213903

page i of

LISTING OF INSPECTED COLUMNS AT 1 WTC

\begin{tabular}{|c|c|c|c|c|}
\hline $\begin{array}{l}\text { ELEVATOR } \\
\text { SHAFT }\end{array}$ & $\begin{array}{l}\text { COLUMN } \\
\text { NUMBER }\end{array}$ & $\begin{array}{c}\text { FLOORS } \\
\text { INSPBCTED }\end{array}$ & $\begin{array}{c}\text { FACE OF } \\
\text { COLUMN } \\
\text { INSPECTED }\end{array}$ & $\begin{array}{l}\text { LISTING OF } \\
\text { PHOTOGRAFHS }\end{array}$ \\
\hline 17 & 908 & $\begin{array}{c}2-44 \\
32\end{array}$ & SEST \& SOUTH & $\frac{1}{3} \cdot \hat{2}$ \\
\hline 22 & 907 & $\begin{array}{c}2-44 \\
32\end{array}$ & EAST & $4,5,6$ \\
\hline $3 \overline{3}$ & 907 & $\begin{array}{c}2-44 \\
32\end{array}$ & WEST \& SOUTH & $\begin{array}{c}7.8,9 \\
10\end{array}$ \\
\hline $4 A$ & 905 & $\begin{array}{c}2-46 \\
\equiv 2\end{array}$ & EAST & 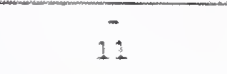 \\
\hline $3 A$ & 903 & $\begin{array}{c}2-44 \\
B 2\end{array}$ & WEST \& SOUTH & 22,23 \\
\hline $9 A$ & 902 & $\begin{array}{c}2-44 \\
52\end{array}$ & $E F S I$ & $\begin{array}{l}\vdots 4 \\
\vdots 5\end{array}$ \\
\hline $12 \mathrm{~A}$ & 601 & $\begin{array}{l}2-78 \\
52\end{array}$ & EAST \& NORTH & $16 .: 7$ \\
\hline $13 \mathrm{~A}$ & 602 & $\begin{array}{c}2-78 \\
82\end{array}$ & WEST \& NORTH & - \\
\hline 162 & 502 & 32 & EAST & - \\
\hline$\therefore E A$ & 603 & B2 & WES" \& NORTH & 30 \\
\hline$-8 \mathrm{~A}$ & 605 & $\begin{array}{c}2-78 \\
32\end{array}$ & EMST \& NORTH & $\begin{array}{c}18,19 \\
-\end{array}$ \\
\hline I9A & 606 & $\begin{array}{c}2-78 \\
\text { B2 }\end{array}$ & WEST & 20 \\
\hline $20 F$ & 506 & 32 & ESST \& NORTH & 32 \\
\hline 218 & 507 & 32 & WEST & - \\
\hline $22 \%$ & 607 & $\begin{array}{c}2-78 \\
32\end{array}$ & EAST \& NORTH & $\begin{array}{l}22 \\
22\end{array}$ \\
\hline
\end{tabular}




\section{LERA}

14 Apri1 2995

File: 1113903

Fage 2 o: 4

LISTING OF INSPECTED COLUMNS AT 1 WTC

\begin{tabular}{|c|c|c|c|c|}
\hline $\begin{array}{c}\text { ELEVATOR } \\
\text { SHAFT }\end{array}$ & $\begin{array}{l}\text { COLUMN } \\
\text { NUMBER }\end{array}$ & $\begin{array}{l}\text { FLOORS } \\
\text { INSPECTED }\end{array}$ & $\begin{array}{c}\text { FACE OF } \\
\text { COLUMN } \\
\text { INSPECTED }\end{array}$ & $\begin{array}{l}\text { LISTING OF } \\
\text { PHOTOGRAEHS }\end{array}$ \\
\hline $23 \pi$ & 608 & $\begin{array}{c}2-78 \\
B 2\end{array}$ & GEST \& NORTH & 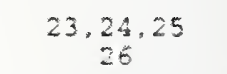 \\
\hline $24 A$ & 807 & 83 & WEST \& NORTH & - \\
\hline $29 A$ & 806 & 83 & EAST \& NOKW"? & $-m$ \\
\hline $30 \mathrm{~A}$ & 806 & 33 & HEST \& NORTH & - \\
\hline $35 \mathrm{~A}$ & 805 & E3 & EAST \& NORTH & - \\
\hline $35 \mathrm{~A}$ & 801 & E3 & EAST \& NORTH & - \\
\hline $4: A$ & 802 & B3 & WEST \& NORTH & - \\
\hline $42 A$ & 802 & E3 & EAST \& NORTH & 34 \\
\hline $47 A$ & 803 & 33 & WEST \& NORTH & - \\
\hline $48 \mathrm{~A}$ & 905 & E3 & EAST \& SOUTH & 35 \\
\hline $49 \mathrm{~A}$ & 704 & 53 & MORTH & 32.33 \\
\hline $50 \mathrm{~A}$ & $\begin{array}{l}704 \\
303 \\
803\end{array}$ & $\begin{array}{l}2-108 \\
2-78 \\
2-108\end{array}$ & $\begin{array}{c}\text { WEST \& SOUTH } \\
\text { EAST } \\
\text { ESST }\end{array}$ & $\begin{array}{c}27,28 \\
29 \\
-\end{array}$ \\
\hline
\end{tabular}




\section{LERA}

14 April 1995

File: 1113903

Page 3 of 4

LISTING OF INSPECTED COLUMNS AT 2 WTC

\begin{tabular}{|c|c|c|c|c|}
\hline $\begin{array}{l}\text { ELEVATOR } \\
\text { SHAFT }\end{array}$ & $\begin{array}{l}\text { COLUMN } \\
\text { NUMBER }\end{array}$ & $\begin{array}{l}\text { FLOORS } \\
\text { INSPECTED }\end{array}$ & $\begin{array}{c}\text { FACE OF } \\
\text { COLUMN } \\
\text { INSPECTED } \\
\end{array}$ & $\begin{array}{l}\text { LISTING OE } \\
\text { PHOTOGRARHS }\end{array}$ \\
\hline 13 & 908 & $\begin{array}{c}2-44 \\
32\end{array}$ & EAST \& SOUTH & 36 \\
\hline 23 & 907 & $\begin{array}{c}2-44 \\
E 2\end{array}$ & NOFT: & 37 \\
\hline 33 & 907 & 32 & EAST SOUTH & $\omega$ \\
\hline 43 & 906 & 32 & NORTE & - \\
\hline 53 & 906 & 52 & EAST $\propto$ SOUTH & 66 \\
\hline $5 B$ & 904 & 82 & EASN \& SOUTE & - \\
\hline 73 & 903 & 82 & NOPTH & - \\
\hline 83 & 903 & $\mathrm{B2}$ & EAST \& SOUTH & 64.65 \\
\hline $9 E$ & 902 & 52 & NORTH & - \\
\hline 203 & 908 & $\begin{array}{c}2-44 \\
32\end{array}$ & EAST \& SOUMA & $\begin{array}{c}38,39 \\
40\end{array}$ \\
\hline$\therefore 23$ & 901 & $\begin{array}{c}2-44 \\
82\end{array}$ & EAST \& NORTH & $\xi:, 42$ \\
\hline 123 & 601 & $\begin{array}{c}2-44 \\
32\end{array}$ & WEST \& WORTH & 43 \\
\hline 133 & 502 & $\begin{array}{c}2-78 \\
=2\end{array}$ & WEST \& SOUNH & 44,45 \\
\hline 148 & 602 & $\begin{array}{c}2-78 \\
\approx 2\end{array}$ & NCRTH & 46,47 \\
\hline 153 & 603 & $\begin{array}{c}2-78 \\
B 2\end{array}$ & MEST SOUTH & 48.49 \\
\hline 168 & 603 & 34 & NORTH & - \\
\hline 178 & 604 & 54 & NEST \& SOUHH & 50 \\
\hline
\end{tabular}




\section{LERA}

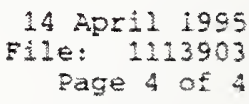

LISTING OF INSPECTED COLUMNS AT 2 WTC

\begin{tabular}{|c|c|c|c|c|}
\hline $\begin{array}{c}\text { ELEVATOR } \\
\text { SHAFT }\end{array}$ & $\begin{array}{l}\text { COLUMN } \\
\text { NUMBER }\end{array}$ & $\begin{array}{c}\text { FLOORS } \\
\text { INSPECTED }\end{array}$ & $\begin{array}{c}\text { FACE OF } \\
\text { COLUMN } \\
\text { INSPECTED } \\
\end{array}$ & $\begin{array}{l}\text { LISTING OF } \\
\text { PHOTOGRAPES }\end{array}$ \\
\hline $18 \mathrm{~B}$ & 505 & 32 & WEST \& MORTH & 51 \\
\hline$\$ 98$ & 505 & $\mathrm{ez}$ & SOUTH & 52 \\
\hline 203 & 606 & $\$ 2$ & WEST \& NORTH & 53 \\
\hline $21 B$ & 507 & $\mathrm{B2}$ & SOUTX & - \\
\hline 228 & 607 & $\begin{array}{c}2-78 \\
32\end{array}$ & WEST \& NORTH & 54 \\
\hline $23 B$ & 608 & $\begin{array}{c}2-78 \\
E 2\end{array}$ & WEST \& SOUTH & 55.56 .57 \\
\hline 368 & 801 & B3 & AEST \& NOETH & - \\
\hline $4: 8$ & 802 & 33 & WEST \& SOUTH & - \\
\hline 423 & 802 & $\mathrm{E3}$ & WEST \& NORTH & - \\
\hline 473 & 803 & B3 & WEST \& SOUTH & 57 \\
\hline 493 & 304 & 36 & WEST \& SOUTA & 62,63 \\
\hline 508 & $\begin{array}{l}704 \\
703 \\
803\end{array}$ & $\begin{array}{l}2-108 \\
2-78 \\
2-108\end{array}$ & $\begin{array}{c}\text { EAST \& SOUTH } \\
\text { NORTH } \\
\text { NORTH }\end{array}$ & $\begin{array}{c}58.59 \\
60.61 \\
-\end{array}$ \\
\hline
\end{tabular}


- 1996 Accessible Columns SII Report (part of WTCI-66-L)

LERA

One and Two Wo-ld Trade Center

Structural Integrity Inspection

17 May 1996

Accessible Columns

File: P1133902

Page 4

4. LIST OF INSPECTED COLUMNS - 1 WTC

\begin{tabular}{|c|c|c|c|}
\hline $\begin{array}{l}\text { Elevator } \\
\text { ShaftPit }\end{array}$ & $\begin{array}{l}\text { Column } \\
\text { Number }\end{array}$ & $\begin{array}{l}\text { PiUfloors } \\
\text { Inspected }\end{array}$ & $\begin{array}{c}\text { Face Of Column } \\
\text { Inspected }\end{array}$ \\
\hline $6 A$ & 904 & $84 / 2-106$ & West \& South \\
\hline $7 A$ & 903 & $B 4 / 2-106$ & East \\
\hline $16 \mathrm{~A}$ & 603 & $B-4 / 2-78$ & East \\
\hline $17 \mathrm{~A}$ & 604 & $B 4 / 2-78$ & West \& South \\
\hline $34 \mathrm{~A}$ & 706 & $\mathrm{E} 1 / 2-24$ & Eas: \& Noth \\
\hline $35 A$ & 805 & $2-24$ & East \& North \\
\hline $42 \mathrm{~A}$ & 802 & $2-40$ & East \& North \\
\hline $43 \mathrm{~A}$ & 702 & $81 / 2 \cdot 40$ & East \& North \\
\hline $55 \mathrm{~A}$ & 707 & 43 & East, North \& South \\
\hline $56 \mathrm{~A}$ & 806 & 43 & East, North \& South \\
\hline $51 \mathrm{~A}$ & 705 & $43 / 44 \cdot 61$ & East \& North \\
\hline $62 A$ & 805 & $43 / 44-61$ & East \& North \\
\hline 634 & 801 & 43 & East. Noth \& South \\
\hline $64 A$ & 701 & 43 & East, North \& South \\
\hline $67 A$ & 702 & 42 & West, North \& South \\
\hline 68A & 802 & 43 & Wes: North \& South \\
\hline $69 A$ & 802 & $43 / 44-74$ & East \& North \\
\hline $70 A$ & 702 & $4 3 \longdiv { 4 4 - 7 4 }$ & East \& North \\
\hline $78 A$ & 707 & 76 & East. Noth \& South \\
\hline 79A & 806 & 76 & East, North \& South \\
\hline
\end{tabular}


LERA

One and Two World Trade Center

17 May 1996

Structural Integrity inspection

File: P1133902

Accessible Columns

Page 5

4. LIST OF INSPECTED COLUMNS - 1 WTC (continued)

\begin{tabular}{|c|c|c|c|}
\hline $\begin{array}{c}\text { Elevator } \\
\text { ShaftPit }\end{array}$ & $\begin{array}{c}\text { Column } \\
\text { Number }\end{array}$ & $\begin{array}{c}\text { Pivfloors } \\
\text { Inspected }\end{array}$ & $\begin{array}{c}\text { Face Ot Column } \\
\text { Inspected }\end{array}$ \\
\hline $82 \mathrm{~A}$ & 801 & 77 & East, Noth \& South \\
\hline $83 \mathrm{~A}$ & 701 & 77 & East, North \& South \\
\hline $88 \mathrm{~A}$ & 802 & $77778-100$ & East \& North \\
\hline $89 \mathrm{~A}$ & 702 & $77778-100$ & East, North \& South \\
\hline $94 \mathrm{~A}$ & 805 & $7778-107$ & East \& North \\
\hline $95 \mathrm{~A}$ & 706 & $7778-107$ & East. North \& South \\
\hline $96 \mathrm{~A}$ & 707 & $77778-105$ & West \& South \\
\hline $97 \mathrm{~A}$ & 806 & $7778-105$ & West, North \& South \\
\hline $99 \mathrm{~A}$ & 703803 & $505 / 106-110$ & West \\
\hline
\end{tabular}

Previously Inspected

\begin{tabular}{|c|c|c|c|}
\hline $\begin{array}{c}\text { Elevator } \\
\text { ShatuPit }\end{array}$ & $\begin{array}{c}\text { Column } \\
\text { Number }\end{array}$ & $\begin{array}{c}\text { Pit/Floors } \\
\text { Inspected }\end{array}$ & $\begin{array}{c}\text { Face Ot Column } \\
\text { Inspected }\end{array}$ \\
\hline $1 \mathrm{~A}$ & 908 & $\mathrm{~B} 2 / 2-44$ & West \& South \\
\hline $2 \mathrm{~A}$ & 907 & $\mathrm{~B} 2 / 2-44$ & East \\
\hline $3 A$ & 907 & $\mathrm{~B} 2 / 2-44$ & West \& South \\
\hline $4 \mathrm{~A}$ & 906 & $\mathrm{~B} 2 / 2-44$ & East \\
\hline $8 \mathrm{~A}$ & 903 & $\mathrm{~B} 2 / 2-44$ & Wes: \& South \\
\hline 94 & 902 & $\mathrm{E} 2 / 2-44$ & East \\
\hline $12 \mathrm{~A}$ & 601 & $\mathrm{~B} 2 / 2.78$ & East \& North \\
\hline 134 & 602 & $\mathrm{~B} 2 / 2-78$ & West \& North \\
\hline
\end{tabular}




\section{LERA}

One and Two World Trade Center

Struclu:al Iniegrity Inspection

17 May 1996

Accessible Columns

4. LIST OF INSPECTED COLUMNS - 1 WTC (continued)

Previously inspected

\begin{tabular}{|c|c|c|c|}
\hline $\begin{array}{l}\text { Elevator } \\
\text { Shaft/Pit }\end{array}$ & $\begin{array}{l}\text { Column } \\
\text { Number }\end{array}$ & $\begin{array}{l}\text { Pivfloors } \\
\text { Inspected }\end{array}$ & $\begin{array}{c}\text { Face of Column } \\
\text { Inspected }\end{array}$ \\
\hline $14 \mathrm{~A}$ & 502 & 82 & East \\
\hline $15 \mathrm{~A}$ & 603 & 82 & West \& North \\
\hline $18 \mathrm{~A}$ & 605 & $82 / 2-78$ & East \& North \\
\hline $19 \mathrm{~A}$ & 606 & $\mathrm{~B} 2 / 2-78$ & West \\
\hline $20 \mathrm{~A}$ & 605 & $\mathrm{~B} 2 / 4-78$ & East \& North \\
\hline $21 \mathrm{~A}$ & 607 & $\mathrm{~B} 2 / 4-78$ & East \& West \\
\hline $22 \mathrm{~A}$ & 607 & $\mathrm{~B} 2 / 2-78$ & East \& North \\
\hline $23 A$ & 608 & $\mathrm{~B} 2 / 2-78$ & West \& North \\
\hline $24 \mathrm{~A}$ & $80 ?$ & $\mathrm{~B} 3$ & West \& North \\
\hline $29 A$ & 806 & B3 & East \& North \\
\hline $30 A$ & 805 & $\mathrm{~B} 3$ & West \& North \\
\hline $35 \mathrm{~A}$ & 805 & $\mathrm{B3}$ & East \& North \\
\hline $36 \mathrm{~A}$ & 801 & $\mathrm{~B} 3 / 1-32$ & East \& North \\
\hline $37 \mathrm{~A}$ & 701 & $1-32$ & East \& South \\
\hline $41 \mathrm{~A}$ & 802 & $B 3$ & West \& North \\
\hline $42 A$ & 802 & 83 & East \& North \\
\hline $47 \mathrm{~A}$ & 803 & B3 & West \& North \\
\hline
\end{tabular}




\section{LERA}

One and Two World Trade Center

Structural Integrity Inspection

17 May 1996

Accessible Columns

4. LIST OF INSPECTED COLUMNS - 1 WTC (continued)

Previously Inspected

\begin{tabular}{|c|c|c|c|}
\hline $\begin{array}{l}\text { Elevator } \\
\text { ShattPit }\end{array}$ & $\begin{array}{l}\text { Column } \\
\text { Number }\end{array}$ & $\begin{array}{l}\text { Pivfloors } \\
\text { Inspected }\end{array}$ & $\begin{array}{c}\text { Face Of Column } \\
\text { Inspected }\end{array}$ \\
\hline $48 \mathrm{~A}$ & 905 & $\mathrm{B3}$ & East \& South \\
\hline $49 A$ & 704 & $\mathrm{~B} 3$ & North \\
\hline $50 A$ & $\begin{array}{l}704 \\
703 \\
803\end{array}$ & $\begin{array}{l}2-108 \\
2-78 \\
2-108\end{array}$ & $\begin{array}{c}\text { West \& South } \\
\text { East } \\
\text { East }\end{array}$ \\
\hline $63 \mathrm{~A}$ & 701 & $45-67$ & East \& South \\
\hline 64A & 801 & $45-67$ & East \& South \\
\hline $73 \mathrm{~A}$ & 703 & 43.74 & North \& West \\
\hline $74 A$ & 803 & $43-74$ & North \& West \\
\hline $82 A$ & 801 & $78-93$ & East \& South \\
\hline $83 A$ & 701 & 78.93 & East \& North \\
\hline
\end{tabular}




\section{LERA}

One and Two World Trade Center

Structural Integrity Inspection

17 May 1996

Accessiole Columns

\section{LIST OF INSPECTED COLUMNS - 2 WTC}

\begin{tabular}{|c|c|c|c|}
\hline $\begin{array}{l}\text { Elevator } \\
\text { ShaftPit }\end{array}$ & $\begin{array}{l}\text { Column } \\
\text { Number }\end{array}$ & $\begin{array}{l}\text { Pitfloors } \\
\text { Inspected }\end{array}$ & $\begin{array}{l}\text { Face Of Column } \\
\text { Inspected }\end{array}$ \\
\hline $6 \mathrm{~B}$ & 904 & 2.106 & East \& South \\
\hline $7 B$ & 903 & $2-106$ & North \\
\hline $18 B$ & 605 & $2-78$ & West \& North \\
\hline $19 B$ & 606 & $2-78$ & South \\
\hline $20 B$ & 606 & 2.78 & West \& North \\
\hline $21 B$ & 607 & 2.78 & South \\
\hline $34 B$ & 706 & $\mathrm{~B} 1 / 2-23$ & West \& North \\
\hline 358 & 805 & $B 3 / 2-23$ & West \& North \\
\hline 423 & 802 & $2-40$ & West \& North \\
\hline 433 & 702 & $B 1 / 2 \cdot 40$ & West \& North \\
\hline $48 B$ & 905 & $\mathrm{B3}$ & East \& North \\
\hline $55 B$ & 707 & 43 & East, West \& North \\
\hline 568 & 805 & 43 & East, West \& North \\
\hline $61 B$ & 705 & $43 / 44-61$ & West \& North \\
\hline $62 \mathrm{~B}$ & 805 & $43 / 44-61$ & West \& North \\
\hline $63 B$ & 801 & 43 & East, West \& North \\
\hline $64 \mathrm{~B}$ & 701 & 43 & East, West \& North \\
\hline $67 B$ & 702 & 42 & East, West \& South \\
\hline $68 B$ & 802 & 43 & East, West \& South \\
\hline 693 & 802 & $43 / 44-74$ & West \& North \\
\hline
\end{tabular}


One and Two Wortd Trade Center

17 May 1996

Structural Integrity Inspection

File: P1133902

Accessible Columns

Page 12

5. LIST OF INSPECTED COLUMNS - 2 WTC (continued)

\begin{tabular}{|c|c|c|c|}
\hline $\begin{array}{l}\text { Elevator } \\
\text { Shatuph }\end{array}$ & $\begin{array}{l}\text { Column } \\
\text { Number }\end{array}$ & $\begin{array}{l}\text { Pit/Floors } \\
\text { Inspected }\end{array}$ & $\begin{array}{c}\text { Face Of Column } \\
\text { Inspected }\end{array}$ \\
\hline $70 B$ & 702 & $43 / 44-74$ & West \& North \\
\hline $78 B$ & 707 & 76 & East, West \& North \\
\hline $79 \mathrm{~B}$ & 806 & 76 & East, West \& North \\
\hline $82 B$ & 801 & 77 & East, West \& North \\
\hline $83 B$ & 701 & 77 & East, West \& North \\
\hline 888 & 802 & $77 \pi 8-100$ & East, West \& North \\
\hline $89 B$ & 702 & $77778-100$ & East, West \& North \\
\hline $95 B$ & 706 & 77 & West \& North \\
\hline $96 \mathrm{~B}$ & 707 & $7778-106$ & East, West \& South \\
\hline $97 \mathrm{~B}$ & 805 & $7778-106$ & West \& South \\
\hline $99 B$ & 7031803 & $105 / 106-110$ & South \\
\hline
\end{tabular}

Previously Inspected

\begin{tabular}{|c|c|c|c|}
\hline $\begin{array}{c}\text { Elevator } \\
\text { ShaftPit }\end{array}$ & $\begin{array}{c}\text { Column } \\
\text { Number }\end{array}$ & $\begin{array}{c}\text { Pitsfloors } \\
\text { Inspected }\end{array}$ & $\begin{array}{c}\text { Face Of Column } \\
\text { Inspected }\end{array}$ \\
\hline $1 \mathrm{~B}$ & 908 & $\mathrm{~B} 2 / 2-44$ & East \& South \\
\hline $2 \mathrm{~B}$ & 907 & $\mathrm{~B} 2 f 2-44$ & North \\
\hline $3 \mathrm{~B}$ & 907 & $\mathrm{~B} 2$ & East \& South \\
\hline $4 \mathrm{~B}$ & 906 & $\mathrm{~B} 2$ & North \\
\hline 58 & 906 & $\mathrm{~B} 2$ & East \& South \\
\hline 68 & 904 & $\mathrm{~B} 2$ & East \& South \\
\hline
\end{tabular}




\section{LERA}

One and Two World Trade Center

Structural Integrity inspection

17 May 1996

Accessible Columns

File: P1133902

Page 13

5. LIST OF INSPECTED COLUMNS - 2 WTC (COntinued)

Previously Inspected

\begin{tabular}{|c|c|c|c|}
\hline $\begin{array}{l}\text { Elevator } \\
\text { ShattPit }\end{array}$ & $\begin{array}{l}\text { Column } \\
\text { Number }\end{array}$ & $\begin{array}{l}\text { Pits/Floors } \\
\text { Inspected }\end{array}$ & $\begin{array}{l}\text { Face of Column } \\
\text { Inspected }\end{array}$ \\
\hline $7 B$ & 903 & $\mathrm{~B} 2$ & North \\
\hline 88 & 903 & $\mathrm{~B} 2$ & East \& South \\
\hline 98 & 902 & $\mathrm{~B} 2$ & North \\
\hline 108 & 908 & $B 2 / 2.44$ & East \& South \\
\hline $11 B$ & 901 & $32 / 2-44$ & East \& North \\
\hline 128 & 601 & $32 / 2-44$ & West \& North \\
\hline $13 B$ & 602 & $\mathrm{~B} 2 / 2-78$ & West \& South \\
\hline 148 & 602 & $32 / 2-78$ & North \\
\hline $15 B$ & 603 & $\mathrm{~B} 2 / 2-78$ & West \& South \\
\hline 168 & 603 & EA & North \\
\hline $17 B$ & 604 & B4 & West \& South \\
\hline 188 & 605 & 82 & West \& North \\
\hline $19 B$ & 606 & $\mathrm{~B} 2$ & South \\
\hline $20 B$ & 606 & $\mathrm{E} 2$ & West \& North \\
\hline 218 & 607 & $\mathrm{B2}$ & South \\
\hline $22 B$ & 607 & $E 2 / 2-78$ & West \& North \\
\hline 238 & 608 & $\mathrm{~B} 22-78$ & West \& South \\
\hline $28 B$ & 707 & $1-16$ & East \& South \\
\hline 293 & 805 & $1-16$ & West \& South \\
\hline
\end{tabular}


LERA

One and Two Worid Trade Center

Structural Integrity Inspection

17 May 1996

Accessible Columns

File: P1133902

Page 14

5. LIST OF PREVIOUSLY INSPECTED - 2 WTC (continued)

Previously Inspected

\begin{tabular}{|c|c|c|c|}
\hline $\begin{array}{c}\text { Elevator } \\
\text { Shatt/Pit }\end{array}$ & $\begin{array}{c}\text { Column } \\
\text { Number }\end{array}$ & $\begin{array}{c}\text { Pitfloors } \\
\text { Inspected }\end{array}$ & $\begin{array}{c}\text { Face Of Column } \\
\text { Inspected }\end{array}$ \\
\hline $35 B$ & 801 & $B 3$ & West \& North \\
\hline $41 B$ & 802 & $B 3$ & West \& South \\
\hline $42 B$ & 802 & $B 3$ & West \& North \\
\hline 478 & 803 & $B 3$ & West \& South \\
\hline 498 & 704 & 86 & West \& South \\
\hline $50 B$ & 704 & $2-108$ & East \& South \\
& 703 & $2-78$ & North \\
\hline $55 B$ & 703 & $2-108$ & East \& South \\
\hline $55 B$ & 806 & $45-54$ & East \& West \\
\hline $78 B$ & 707 & $78-86$ & East \& South \\
\hline 798 & 806 & $78-86$ & East \& West \\
\hline
\end{tabular}


- 1997 Accessible Columns SII Report (part of WTCI-66-L)

\section{LERA}

One and Two World Trade Center

23 May 1997

Structural Integrity inspection

File: P\$153903

Accessible Columns

Page 4

\section{LIST OF INSPECTED COLUMNS - 1 WTC}

\begin{tabular}{|c|c|c|c|}
\hline $\begin{array}{l}\text { Elevator } \\
\text { ShaftPit }\end{array}$ & $\begin{array}{l}\text { Column } \\
\text { Number }\end{array}$ & $\begin{array}{l}\text { Pitfioors } \\
\text { Inspected }\end{array}$ & $\begin{array}{c}\text { Face O Column } \\
\text { Inspected }\end{array}$ \\
\hline $10 A$ & 902 & B1/2-44 & West \& South \\
\hline $11 A$ & S01 & $81 / 2.44$ & East \& South \\
\hline $24 \mathrm{~A}(\mathrm{SO})$ & 807 & $2-17$ & West \& Norih \\
\hline 25A(SO) & 708 & $2-17$ & West \& South \\
\hline $40 \mathrm{~A}$ & 702 & $81 / 2-33$ & West \& North \\
\hline $4 i A(S O)$ & 802 & $2-33$ & West \& North \\
\hline $51 \mathrm{~A}$ & 807 & $43 / 44-54$ & West \& North \\
\hline $52 A$ & 708 & $43 / 44-54$ & West \& South \\
\hline $57 \AA$ & 806 & $43 / 42-61$ & Wesi \& North \\
\hline $58 \mathrm{~A}$ & 707 & $43 / 44 \cdot 61$ & West \& South \\
\hline $76 A$ & 807 & $77776-86$ & West \& South \\
\hline $77 \mathrm{~A}$ & 708 & $77 \pi 8-86$ & West 8 South \\
\hline $84 \mathrm{~A}$ & 702 & $77 / 78.93$ & West \& Sount \\
\hline $85 A$ & 802 & $7778-93$ & West \& Norh \\
\hline $90 \mathrm{~A}$ & 703 & $77778-100$ & West \& South \\
\hline $91 A$ & 803 & $77 / 78-100$ & West \& North \\
\hline
\end{tabular}

-(SO) Indicates the shat only, not the pit, has been inspected 


\section{LERA}

One and Two World Trade Center

23 May 1997

Structural Integrity Inspection

File: P1153903

Accessible Columns

Page 5

4. LIST OF INSPECTED COLUMNS - 1 WTC (continued)

Previously Inspected

\begin{tabular}{|c|c|c|c|}
\hline $\begin{array}{l}\text { Elevator } \\
\text { ShatuPit }\end{array}$ & $\begin{array}{l}\text { Column } \\
\text { Number }\end{array}$ & $\begin{array}{l}\text { PiUfloors } \\
\text { Inspected }\end{array}$ & $\begin{array}{c}\text { Face of Column } \\
\text { Inspected }\end{array}$ \\
\hline $1 \mathrm{~A}$ & 908 & $B 2 / 2.44$ & West \& South \\
\hline $2 A$ & 907 & $B 2 / 2-44$ & East \\
\hline $3 A$ & 907 & $82 / 2-44$ & West \& South \\
\hline $4 A$ & 906 & $82 / 2 \times 44$ & East \\
\hline 6A & 904 & $84 / 2 \cdot 106$ & West \& South \\
\hline $7 A$ & 903 & B4:2+106 & East \\
\hline $8 A$ & 903 & $E 2 / 2-44$ & West \& South \\
\hline QA & 902 & $92 / 2-44$ & East \\
\hline $12 \mathrm{~A}$ & 601 & $B 2 / 2.78$ & East \& North \\
\hline $13 \mathrm{~A}$ & 602 & $82 / 2-76$ & West \& North \\
\hline $14 \mathrm{~A}$ & 602 & $\mathrm{~B} 2$ & East \\
\hline $15 \mathrm{~A}$ & 603 & $B 2$ & West \& North \\
\hline $16 \mathrm{~A}$ & 603 & $B 4 / 2-78$ & East \\
\hline $17 \mathrm{~A}$ & 604 & $84 / 2-78$ & West \& South \\
\hline $18 \mathrm{~A}$ & 605 & $82 / 2-78$ & East \& North \\
\hline $19 \mathrm{~A}$ & 606 & $\mathrm{~B} 2 / 2 \cdot 78$ & West \\
\hline $20 \mathrm{~A}$ & 606 & $\mathrm{~B} 2 / 4-78$ & East \& North \\
\hline $21 \mathrm{~A}$ & 607 & $B 2 / 4-78$ & East \& West \\
\hline $22 \mathrm{~A}$ & 607 & $82 / 2 \cdot 78$ & East \& North \\
\hline $23 \mathrm{~A}$ & 608 & $82 / 2-78$ & West \& North \\
\hline
\end{tabular}




\section{LERA}

One and Two World Trade Center

Structural Integrity Inspection

23 May 1997

Accessible Columns

File: P1153903

Page 6

4. LIST OF INSPECTED COLUMNS - 1 WTC (continued)

Previously Inspocted

\begin{tabular}{|c|c|c|c|}
\hline $\begin{array}{l}\text { Elevator } \\
\text { Shaft/Pit } \\
\end{array}$ & $\begin{array}{l}\text { Column } \\
\text { Number }\end{array}$ & $\begin{array}{l}\text { Pitfloors } \\
\text { Inspected }\end{array}$ & $\begin{array}{l}\text { Face of Column } \\
\text { Inspected }\end{array}$ \\
\hline $24 A$ & 807 & $\mathrm{B3}$ & West \& North \\
\hline $29 A$ & 806 & B3 & East \& North \\
\hline $30 \mathrm{~A}$ & 806 & $\mathbf{E 3}$ & West \& Nonh \\
\hline $3 \angle A$ & 706 & B $1 / 2 \cdot 24$ & East \& North \\
\hline $35 A$ & 805 & $83 / 2 \cdot 24$ & Eas: $\&$ North \\
\hline $36 A$ & 801 & $83 / 1-32$ & East \& North \\
\hline $37 A$ & 701 & 1.32 & East \& South \\
\hline $41 A$ & 802 & E3 & Wes: \& North \\
\hline $42 A$ & 802 & $33 / 2 \cdot 40$ & East \& North \\
\hline $43 A$ & 702 & $31 / 2-40$ & East \& North \\
\hline 47A & 803 & $\mathrm{B3}$ & West \& Norh \\
\hline $48 A$ & 905 & $\mathrm{B3}$ & East \& South \\
\hline $49 A$ & 704 & $B 3$ & North \\
\hline $50 \mathrm{~A}$ & 704 & $2-108$ & West \& Souln \\
\hline $5 C A$ & 75 & 2.78 & East \\
\hline $5 C A$ & 200 & $2 \cdot 108$ & East \\
\hline $55 A$ & 707 & 43 & Eas:, North \& South \\
\hline $56 A$ & 806 & 43 & Easl, North \& South \\
\hline GIA & 706 & $43 / 44-61$ & East \& North \\
\hline $62 A$ & 805 & $43 / 44-6 i$ & East \& North \\
\hline 634 & 801 & 43 & East, North \& South \\
\hline
\end{tabular}




\section{LERA}

One and Two Wortd Trade Center

Structural Integrity inspection

Accessible Columns
23 May 1997

Fite: P1153903

Page 7

4. LIST OF INSPECTED COLUMNS - 1 WTC (continued)

Previously Inspected

\begin{tabular}{|c|c|c|c|}
\hline $\begin{array}{l}\text { Elevator } \\
\text { ShaftPi! }\end{array}$ & $\begin{array}{l}\text { Column } \\
\text { Number }\end{array}$ & $\begin{array}{l}\text { PiUfloors } \\
\text { Inspected }\end{array}$ & $\begin{array}{c}\text { Face Of Column } \\
\text { Inspected }\end{array}$ \\
\hline 63A & 801 & $45-67$ & East \& South \\
\hline 644 & 701 & $43 / 45-67$ & Eas: Noth \& South \\
\hline $67 \mathrm{~A}$ & 702 & 42 & West, North \& South \\
\hline $68 \mathrm{~A}$ & 802 & 43 & West, North \& South \\
\hline $6 S A$ & 802 & $43 / 44 \cdot 74$ & East \& North \\
\hline $70 A$ & 702 & $43 / 44 \cdot 74$ & East \& North \\
\hline 734 & 703 & $43-74$ & North \& West \\
\hline $74 A$ & 803 & $43-74$ & North \& West \\
\hline $78 \mathrm{~A}$ & 707 & 76 & East, Nortr 8 South \\
\hline $79 A$ & 806 & 76 & East, North \& South \\
\hline $82 \mathrm{~A}$ & 801 & 77 & East, North \& South \\
\hline $82 \mathrm{~A}$ & 801 & $78 \cdot 93$ & East \& South \\
\hline 834 & 701 & 77 & East, North \& South \\
\hline $83 A$ & 701 & $78-93$ & Easi 8 North \\
\hline B8A & 802 & $77 / 78 \cdot 100$ & East \& North \\
\hline $89 A$ & 702 & $7778-100$ & East, North \& South \\
\hline $94 \mathrm{~A}$ & 805 & $77 \pi 8-107$ & East \& North \\
\hline $95 A$ & 706 & $77778-107$ & East, North \& South \\
\hline $96 \mathrm{~A}$ & 707 & $77778-105$ & West \& South \\
\hline $97 \mathrm{~A}$ & 805 & $77 / 78 \cdot 106$ & West, North \& South \\
\hline 99A & 703803 & $105 / 106 \times 110$ & West \\
\hline
\end{tabular}




\section{LERA}

One and Two World Trade Center

23 May 1997

Structural Integrity Inspection

File: P1153903

Accessibie Columns

Page 11

\section{LIST OF INSPECTED COLUMNS - 2 WTC}

\begin{tabular}{|c|c|c|c|}
\hline $\begin{array}{l}\text { Elevator } \\
\text { ShattPit* }\end{array}$ & $\begin{array}{l}\text { Column } \\
\text { Number }\end{array}$ & $\begin{array}{l}\text { Pilfioors } \\
\text { Inspected }\end{array}$ & $\begin{array}{l}\text { Face of Column } \\
\text { Inspected }\end{array}$ \\
\hline $5 B(\mathrm{SO})$ & 906 & $81-44$ & East \& South \\
\hline $24 B$ & 807 & $E 3 / 2-16$ & West \& Sounth \\
\hline $25 \mathrm{~B}(\mathrm{SO})$ & 708 & $2-16$ & East \& South \\
\hline 308 & 806 & $83 / 2 \cdot 24$ & West $\&$ South \\
\hline $318(5 O)$ & 707 & $2 \cdot 24$ & East \& South \\
\hline $358(\mathrm{SO})$ & 801 & $2-32$ & West \& North \\
\hline $37 \mathrm{~B}(\mathrm{SO})$ & 701 & $2 \cdot 32$ & Eas: \& North \\
\hline $488(\mathrm{SO})$ & 905 & $\mathrm{~B} 1-40$ & East \& North \\
\hline 518 & 807 & 43.54 & West \& South \\
\hline 528 & 708 & $43-54$ & West \& South \\
\hline $57 \mathrm{~B}$ & 806 & $43-61$ & West \& South \\
\hline 583 & 707 & $43 \cdot 61$ & East \& South \\
\hline $63 \mathrm{~B}(\mathrm{SO})$ & 801 & $44-67$ & West \& North \\
\hline $\operatorname{GAB}(\mathrm{SO})$ & 701 & $44-67$ & West \& North \\
\hline $67 \mathrm{~B}(\mathrm{SO})$ & 702 & $44-67$ & East \& South \\
\hline $68 \mathrm{~B}(\mathrm{SO})$ & 802 & $44 \cdot 67$ & West \& South \\
\hline $73 B(P O)$ & 801 & 43 & East, West \& North \\
\hline $74 \mathrm{~B}(\mathrm{PO})$ & 701 & 43 & East. West \& North \\
\hline $76 B(P O)$ & 702 & 77 & East, West \& South \\
\hline $77 B(P O)$ & 802 & 77 & Eas: West \& South \\
\hline
\end{tabular}




\section{LERA}

One and Two World Trade Center

Structural Integrity inspection

23 May 1997

Accessible Columns

File: P1153903

Page 12

5. LIST OF INSPECTED COLUMNS - 2 WTC (continued)

\begin{tabular}{|c|c|c|c|}
\hline $\begin{array}{c}\text { Elevator } \\
\text { Shatt/Pit* }\end{array}$ & $\begin{array}{c}\text { Column } \\
\text { Number }\end{array}$ & $\begin{array}{c}\text { PiLffloors } \\
\text { inspected }\end{array}$ & $\begin{array}{c}\text { Face Ol Column } \\
\text { Inspected }\end{array}$ \\
\hline $88 \mathrm{~B}(\mathrm{SO})$ & 802 & $79-100$ & West \& North \\
\hline $89 \mathrm{~B}(\mathrm{SO})$ & 702 & $79-100$ & East \& North \\
\hline $90 \mathrm{~B}$ & 703 & $77-100$ & East \& South \\
\hline 918 & 803 & $77-100$ & West \& South \\
\hline
\end{tabular}

- (SO) Indicates the shatt only, not the pit, has been inspecied

(PO) Indicates the pit only, not the shatt, has been inspected

Previously Inspected

\begin{tabular}{|c|c|c|c|}
\hline $\begin{array}{c}\text { Elevator } \\
\text { ShattPi: }\end{array}$ & $\begin{array}{c}\text { Column } \\
\text { Number }\end{array}$ & $\begin{array}{c}\text { Pits/Floors } \\
\text { Inspected }\end{array}$ & $\begin{array}{c}\text { Face Of Column } \\
\text { Inspected }\end{array}$ \\
\hline 18 & 908 & $B 2 / 2-44$ & East \& South \\
\hline $2 B$ & 907 & $B 2 / 2-44$ & North \\
\hline 38 & 907 & $B 2$ & East \& South \\
\hline 48 & 906 & $B 2$ & North \\
\hline 58 & 906 & $B 2$ & East \& South \\
\hline 68 & 904 & $B 2 / 2-106$ & East \& South \\
\hline 78 & 903 & $82 / 2-106$ & North \\
\hline 88 & 903 & 82 & East \& South \\
\hline 98 & 902 & 82 & North \\
\hline 108 & 908 & $B 2 / 2-44$ & East \& South \\
\hline 118 & 901 & $82 / 2-44$ & East \& Norih \\
\hline
\end{tabular}




\section{LERA}

One and Two World Trade Center

Siructural Integrity Inspection

Accessible Columns

5. LIST OF PREVIOUSLY INSPECTED - 2 WTC (continued)

Previously Inspected

\begin{tabular}{|c|c|c|c|}
\hline $\begin{array}{l}\text { Elevator } \\
\text { Shatt/Pit }\end{array}$ & $\begin{array}{l}\text { Column } \\
\text { Number }\end{array}$ & $\begin{array}{l}\text { PiUfloors } \\
\text { Inspected }\end{array}$ & $\begin{array}{c}\text { Face of Column } \\
\text { Inspected }\end{array}$ \\
\hline $12 B$ & 601 & $82 / 2-44$ & West \& North \\
\hline $13 \mathrm{~B}$ & 602 & $82 / 2 \cdot 78$ & West \& South \\
\hline $14 \mathrm{~B}$ & 602 & $82 / 2 \cdot 78$ & North \\
\hline 158 & 603 & $82 / 2-78$ & West \& South \\
\hline$: 68$ & 603 & 84 & North \\
\hline 178 & 604 & $\mathrm{~B} 4$ & West \& South \\
\hline 188 & 605 & $82 / 2 \cdot 78$ & West \& North \\
\hline $19 \mathrm{~B}$ & 606 & $82 / 2 \cdot 78$ & South \\
\hline 208 & 606 & $\mathrm{~B} 2 / 2-78$ & West \& Norn \\
\hline $21 B$ & 607 & $\mathrm{~B} 2 / 2-78$ & South \\
\hline 223 & 607 & $\mathrm{~B} 2 / 2 \cdot 78$ & West \& North \\
\hline $23 \mathrm{~B}$ & 608 & $B 22 \cdot 78$ & West \& South \\
\hline $28 \mathrm{~B}$ & 707 & $1-16$ & East \& South \\
\hline 298 & 806 & $1-16$ & West \& South \\
\hline 348 & 706 & $81 / 2 \cdot 23$ & Wes: \& North \\
\hline 358 & 805 & $83 / 2-23$ & West \& Nortn \\
\hline 368 & 801 & 83 & West \& North \\
\hline 418 & 802 & 83 & West $\&$ South \\
\hline $42 B$ & 802 & $83 / 2 \cdot 40$ & West \& North \\
\hline $43 B$ & 702 & $81 / 2-40$ & West \& North \\
\hline
\end{tabular}




\section{LERA}

One and Two World Traoe Center

23 May 1997

Structural Integrity Inspection

File: P1153903

Accessible Columns

Page 14

5. LIST OF PREVIOUSLY INSPECTED - 2 WTC (continued)

Previously Inspected

\begin{tabular}{|c|c|c|c|}
\hline $\begin{array}{l}\text { Elevator } \\
\text { ShafuPit }\end{array}$ & $\begin{array}{l}\text { Column } \\
\text { Number }\end{array}$ & $\begin{array}{l}\text { Pit/Floors } \\
\text { Inspected }\end{array}$ & $\begin{array}{l}\text { Face of Column } \\
\text { Inspected }\end{array}$ \\
\hline $47 \mathrm{~B}$ & 803 & $\mathrm{B3}$ & West \& South \\
\hline 488 & 905 & $\mathrm{B3}$ & East \& North \\
\hline 498 & 704 & $\mathrm{~B} 6$ & West \& South \\
\hline 508 & 704 & $2 \cdot 108$ & East \& South \\
\hline 508 & 703 & 2.78 & Nom \\
\hline 508 & 863 & $2 \cdot 108$ & Norn \\
\hline 558 & 707 & 43 & Eas:, West \& North \\
\hline 558 & 707 & $45-54$ & East \& South \\
\hline 568 & $80 \hat{0}$ & 43 & Eas!. West \& North \\
\hline 568 & 806 & $45-54$ & East \& West \\
\hline 619 & 700 & $43 / 44.64$ & West \& North \\
\hline $62 \mathrm{~B}$ & 805 & $43 / 44-61$ & Wes! \& Noth \\
\hline 638 & 801 & 43 & East. West \& North \\
\hline 648 & 701 & 43 & East, West \& North \\
\hline 679 & 702 & 42 & East. West \& South \\
\hline 683 & 802 & 43 & East, West \& South \\
\hline 690 & 802 & 4344.74 & West \& Norh \\
\hline 708 & 702 & $43 / 44-74$ & West \& North \\
\hline $78 \mathrm{~B}$ & 707 & 76 & East, West \& North \\
\hline 788 & 707 & $78 \cdot 86$ & East \& South \\
\hline 798 & 806 & 76 & East, West North \\
\hline
\end{tabular}




\section{LERA}

One and Two Wortd Trade Center

Structural Integrity Inspection

Accessible Columins

23 May 1997

File P1153903

Page 15

5. LIST OF PREVIOUSLY INSPECTED - 2 WTC (continued)

Previously Inspected

\begin{tabular}{|c|c|c|c|}
\hline $\begin{array}{c}\text { Elevator } \\
\text { ShattPil }\end{array}$ & $\begin{array}{c}\text { Column } \\
\text { Number }\end{array}$ & $\begin{array}{c}\text { Pitfloors } \\
\text { Inspected }\end{array}$ & $\begin{array}{c}\text { Face Of Column } \\
\text { Inspected }\end{array}$ \\
\hline 798 & 806 & $78-86$ & East \& West \\
\hline $82 B$ & 801 & 77 & East, West \& North \\
\hline 838 & 701 & 77 & East, West \& North \\
\hline $88 B$ & 802 & $77 / 78-100$ & East, Wes! \& North \\
\hline 898 & 702 & $77778-100$ & East, Wes! \& North \\
\hline $95 B$ & 706 & 77 & West \& North \\
\hline 968 & 707 & $77 / 78-106$ & Easi, Wes: \& South \\
\hline 978 & 806 & $77 / 78-106$ & West \& South \\
\hline $99 B$ & $703 / 803$ & $105 / 106-110$ & South \\
\hline
\end{tabular}


- 1998 Accessible Columns SII Report (part of WTCI-66-L)

LERA

One and Two World Trade Center Structural Integrity Inspection Accessible Columns

4. LIST OF INSPECTED COLUMNS - 1 WTC

\begin{tabular}{|c|c|c|c|}
\hline $\begin{array}{l}\text { Elevator } \\
\text { Shaft/Pit" }\end{array}$ & $\begin{array}{l}\text { Column } \\
\text { Number }\end{array}$ & $\begin{array}{l}\text { Pit/Floors } \\
\text { Inspected }\end{array}$ & $\begin{array}{c}\text { Face of Column } \\
\text { Inspected }\end{array}$ \\
\hline $5 \mathrm{~A}$ & 906 & 2.44 & South \& West \\
\hline $14 \mathrm{~A}(\mathrm{SO})$ & 602 & $2-78$ & Eas! \\
\hline $15 \mathrm{~A}(\mathrm{SO})$ & 603 & 2.78 & North \& West \\
\hline 25A(PO) & 708 & B1 & South \& West \\
\hline $28 \mathrm{~A}$ & 707 & $\mathrm{~B} 1 / 2-16$ & North \& Eas: \\
\hline $29 A(S O)$ & 806 & $2-16$ & North \& East \\
\hline 30A(SO) & 806 & $2-24$ & North \& West \\
\hline 31A & 707 & $B 1 / 2 \% 24$ & North \& West \\
\hline $37 \mathrm{~A}(\mathrm{PO})$ & 701 & $B 1$ & North \& East \\
\hline $46 \mathrm{~A}$ & 706 & $81 / 2+40$ & North \& West \\
\hline $47 \mathrm{~A}(\mathrm{SO})$ & 803 & $2-40$ & North \& West \\
\hline $48 \mathrm{~A}(50)$ & 905 & $2-40$ & East \& West \\
\hline $55 \mathrm{~A}(\mathrm{SO})$ & 707 & $44-54$ & North \& East \\
\hline $56 \mathrm{~A}(\mathrm{SO})$ & 806 & 44.54 & North \& East \\
\hline $67 \mathrm{~A}(\mathrm{SO})$ & 702 & $44-67$ & Nont, South \& West \\
\hline $60 \mathrm{~A}(\mathrm{SO})$ & 802 & 44.67 & North, South, \& West \\
\hline $73 \mathrm{~A}(\mathrm{PO})$ & 703 & 43 & North \& West \\
\hline $74 A(P O)$ & 803 & 43 & North \& West \\
\hline $78 \mathrm{~A}(\mathrm{SO})$ & 707 & $78-86$ & North, East \& South \\
\hline 79A(SO) & 806 & $78-86$ & North, East \& South \\
\hline
\end{tabular}

"(SO) Refers to the shaft only, not the pit

(PO) Refers to the pit only, not the shaft 
4. LIST OF INSPECTED COLUMNS - 1 WTC (continued)

Previously Inspected

\begin{tabular}{|c|c|c|c|}
\hline $\begin{array}{l}\text { Elevator } \\
\text { ShafuPit }\end{array}$ & $\begin{array}{l}\text { Column } \\
\text { Number }\end{array}$ & $\begin{array}{l}\text { PiVFloors } \\
\text { Inspected }\end{array}$ & $\begin{array}{c}\text { Face of Column } \\
\text { Inspected }\end{array}$ \\
\hline IA & 908 & $82 / 2-44$ & South \& West \\
\hline $2 A$ & 907 & $\mathrm{~B} 2 / 2 \cdot 44$ & East \\
\hline उA & 907 & $82 / 2.44$ & South \& West \\
\hline $4 \mathrm{~A}$ & 906 & $32 / 2-44$ & East \\
\hline $6 A$ & 904 & $84 / 2 \cdot 106$ & Scuth \& West \\
\hline $7 A$ & 903 & $\mathrm{E} 4: 2-106$ & Eas! \\
\hline $8 A$ & 903 & $82 / 2-44$ & South \& West \\
\hline $9 A$ & 902 & $82 / 2-44$ & East \\
\hline $10 \mathrm{~A}$ & 902 & $B 1 / 2-44$ & South \& West \\
\hline $11 \mathrm{~A}$ & 901 & B 1/2-44 & East \& South \\
\hline $12 \mathrm{~A}$ & 601 & $B 2 / 2-78$ & North \& East \\
\hline $13 \mathrm{~A}$ & 602 & $\mathrm{~B} 2 / 2-78$ & North \& West \\
\hline $14 \mathrm{~A}(\mathrm{PO})$ & 602 & $\mathrm{~B} 2$ & East \\
\hline $15 \mathrm{~A}(\mathrm{PO})$ & 603 & 82 & North \& West \\
\hline $16 \mathrm{~A}$ & 603 & $\mathrm{~B} 4 / 2-78$ & East \\
\hline $17 \mathrm{~A}$ & 604 & $84 / 2-78$ & North \& West \\
\hline $18 \mathrm{~A}$ & 605 & $B 2 / 2-78$ & North \& East \\
\hline $19 A$ & 606 & $82 / 2-78$ & West \\
\hline $20 A$ & 606 & $B 2 / 4 \cdot 78$ & North \& East \\
\hline $21 \mathrm{~A}$ & 607 & $82 / 4-73$ & West \\
\hline $22 \mathrm{~A}$ & 607 & $B 2 / 2.78$ & North \& East \\
\hline $23 \mathrm{~A}$ & 608 & $\mathrm{~B} 2 / 2-78$ & North \& West \\
\hline $24 \mathrm{~A}$ & 807 & $\mathrm{~B} 3 / 2-17$ & North \& West \\
\hline 25A(SO) & 708 & $2-17$ & South \& West \\
\hline $29 A(P O)$ & 806 & B3 & North \& East \\
\hline
\end{tabular}


LERA
One and Two World Trade Center Structural integrity inspection Accessible Columns

4. LIST OF INSPECTED COLUMNS - 1 WTC (continued)

Previously inspected (continued)

\begin{tabular}{|c|c|c|c|}
\hline $\begin{array}{l}\text { Elevator } \\
\text { Shatt/Pit }\end{array}$ & $\begin{array}{l}\text { Column } \\
\text { Number }\end{array}$ & $\begin{array}{l}\text { Pitfloors } \\
\text { Inspected }\end{array}$ & $\begin{array}{c}\text { Face of Column } \\
\text { Inspected }\end{array}$ \\
\hline $30 \mathrm{~A}(\mathrm{PO})$ & 806 & 83 & North \& West \\
\hline $34 \mathrm{~A}$ & 706 & $81 / 2-24$ & North \& East \\
\hline $35 \mathrm{~A}$ & 805 & $B 3 / 2-24$ & North \& East \\
\hline $36 \mathrm{~A}$ & 801 & $B 3 / 2-32$ & North \& East \\
\hline $37 \mathrm{~A}(\mathrm{SO})$ & 701 & $2 \cdot 32$ & Eas: \& South \\
\hline $40 \mathrm{~A}$ & 702 & $81 / 2-33$ & North \& West \\
\hline $41 \mathrm{~A}$ & 802 & $83 / 2-33$ & North \& West \\
\hline $42 A$ & 802 & $83 / 2.40$ & North \& East \\
\hline $43 \mathrm{~A}$ & 702 & B: $/ 2-40$ & North \& East \\
\hline $47 \mathrm{~A}(\mathrm{PO})$ & 803 & E3 & West \& North \\
\hline $48 \mathrm{~A}(\mathrm{PO})$ & 905 & 83 & East \& South \\
\hline $50 \mathrm{~A}$ & 704 & $63 / 2-108$ & North, South \& West \\
\hline 50A $(\mathrm{SO})$ & 703 & 2.78 & East \\
\hline $50 A(S O)$ & 803 & $2 \cdot 108$ & East \\
\hline $5: A$ & 807 & $43 / 44.54$ & North \& West \\
\hline $52 \mathrm{~A}$ & 708 & $43 / 44-54$ & North \& West \\
\hline $55 \mathrm{~A}(\mathrm{PO})$ & 707 & 43 & East, North \& Soum \\
\hline $56 \mathrm{~A}(\mathrm{PO})$ & 806 & 43 & East. North \& South \\
\hline $57 \mathrm{~A}$ & 806 & $43 / 44.61$ & South \& West \\
\hline $58 \mathrm{~A}$ & 707 & $43 / 44.61$ & South \& West \\
\hline EIA & 706 & $43 / 44 \cdot 61$ & North \& East \\
\hline $62 \mathrm{~A}$ & 805 & $43 / 44-61$ & North \& Easi \\
\hline $63 \mathrm{~A}$ & 801 & 43 & North \& East \\
\hline $64 \mathrm{~A}$ & 701 & $43 / 45-67$ & North, East \& South \\
\hline $67 \mathrm{~A}(\mathrm{PO})$ & 702 & 42 & West, North \& South \\
\hline $6 \mathrm{BA}(\mathrm{PO})$ & 802 & 43 & West. North \& South \\
\hline
\end{tabular}


LERA
One and Two World Trade Center Structural Integrity Inspection Accessible Columns

4. LIST OF INSPECTED COLUMNS - 1 WTC (continued)

Previously Inspected (continued)

\begin{tabular}{|c|c|c|c|}
\hline $\begin{array}{l}\text { Elevator } \\
\text { Shatt/Pit }\end{array}$ & $\begin{array}{l}\text { Column } \\
\text { Number }\end{array}$ & $\begin{array}{l}\text { Pit/Floors } \\
\text { Inspected }\end{array}$ & $\begin{array}{l}\text { Face of Column } \\
\text { Inspected }\end{array}$ \\
\hline $69 \mathrm{~A}$ & 802 & $43 / 44-74$ & North \& East \\
\hline $70 \mathrm{~A}$ & 702 & $43 / 44-74$ & North \& Eas: \\
\hline $73 \mathrm{~A}(\mathrm{SO})$ & 703 & $43-74$ & North \& West \\
\hline $7 \angle \mathrm{A}(\mathrm{SO})$ & 803 & 43.74 & North \& West \\
\hline $76 \mathrm{~A}$ & 807 & $77 / 78.86$ & West \& South \\
\hline $73 \mathrm{~A}$ & 708 & $77 / 78-85$ & West \& South \\
\hline $78 \mathrm{~A}(\mathrm{PO})$ & 707 & 76 & North, East \& South \\
\hline $79 \mathrm{~A}(\mathrm{PO})$ & 806 & 76 & North, East \& South \\
\hline$\varepsilon 2 \mathrm{~A}(\mathrm{PO})$ & 801 & 77 & North. East \& South \\
\hline $\mathrm{E} 2 \mathrm{~A}(\mathrm{SO})$ & 801 & $78-93$ & East \& South \\
\hline $83 A(P O)$ & 701 & 77 & North, East \& South \\
\hline $83 \mathrm{~A}(\mathrm{SO})$ & 701 & $78-93$ & North \& East \\
\hline $84 \mathrm{~A}$ & 702 & $7778-93$ & South \& West \\
\hline $85 A$ & 802 & $77 / 78-93$ & North \& West \\
\hline 884 & 802 & $77 / 78-100$ & North \& East \\
\hline $89 A$ & 702 & $77 / 78.100$ & North, East \& South \\
\hline $90 \mathrm{~A}$ & 703 & $77 / 78-100$ & West \& South \\
\hline $91 \mathrm{~A}$ & 803 & $77 / 78-100$ & North \& West \\
\hline $94 \mathrm{~A}$ & 805 & $77 / 78-107$ & Norin \& Eas: \\
\hline $95 \mathrm{~A}$ & 706 & $77 / 78-107$ & East \& South \\
\hline $96 \mathrm{~A}$ & 707 & $77 / 78-106$ & South \& West \\
\hline $97 \mathrm{~A}$ & 806 & $77 / 78-106$ & North, South \& West \\
\hline $99 \mathrm{~A}$ & $703 / 803$ & $105 / 106-110$ & West \\
\hline
\end{tabular}


5. LIST OF INSPECTED COLUMNS - 2 WTC

\begin{tabular}{|c|c|c|c|}
\hline $\begin{array}{l}\text { Elevator } \\
\text { ShattPit* }\end{array}$ & $\begin{array}{l}\text { Column } \\
\text { Number }\end{array}$ & $\begin{array}{l}\text { Pivfioors } \\
\text { Inspected }\end{array}$ & $\begin{array}{c}\text { Face Of Column } \\
\text { Inspected }\end{array}$ \\
\hline $3 \mathrm{~B}(\mathrm{SO})$ & 907 & $2-44$ & East \& South \\
\hline $4 \mathrm{~B}(\mathrm{SO})$ & 906 & $2 \sim 44$ & North \\
\hline $\mathrm{BB}(\mathrm{SO})$ & 903 & $2-44$ & South \& West \\
\hline $98(50)$ & 902 & $2-44$ & North \\
\hline $16 \mathrm{~B}(\mathrm{SO})$ & 603 & $2-78$ & North \\
\hline $17 \mathrm{~B}(\mathrm{SO})$ & 604 & 2.78 & South \& West \\
\hline $25 \mathrm{~B}\{\mathrm{PO}\}$ & 708 & 81 & East \& South \\
\hline $28 \mathrm{~B}(\mathrm{PO})$ & 707 & $\mathrm{B1}$ & East \& South \\
\hline $298(P O)$ & 806 & $\mathrm{B1}$ & North \& West \\
\hline $31 \mathrm{E}(\mathrm{PO})$ & 707 & B1 & South \& West \\
\hline $37 \mathrm{~B}(\mathrm{PO})$ & 701 & 81 & North \& West \\
\hline 408 & 702 & $31 / 2-32$ & South \& Wes: \\
\hline $41 \mathrm{~B}(\mathrm{SO})$ & 802 & $2-32$ & South \& West \\
\hline $46 \mathrm{~B}$ & 703 & $\mathrm{~B} 1 / 2-32$ & South \& West \\
\hline $47 \mathrm{~B}(50)$ & 803 & $2 \cdot 40$ & South \& West \\
\hline $490(50)$ & 703 & $2-74$ & North \\
\hline $73 \mathrm{~B}(50)$ & 703 & $44-74$ & Soutn \& West \\
\hline $74 \mathrm{~B}(50)$ & 803 & $44-74$ & South \& West \\
\hline $763(50)$ & 807 & $78 \cdot 66$ & East \& South \\
\hline $778(50)$ & 708 & $78-86$ & East \& South \\
\hline $82 \mathrm{~B}(50)$ & 801 & $78-93$ & North, East \& West \\
\hline $83 B(50)$ & 701 & 78.93 & North, East \& West \\
\hline 848 & 702 & $77 / 78-93$ & East \& South \\
\hline 858 & 802 & $77 / 78-93$ & East \& South \\
\hline $94 B$ & 805 & $27778+107$ & North \& East \\
\hline $958(50)$ & 706 & $78-107$ & North \& East \\
\hline
\end{tabular}

" (SO) Refers to the shatt only, not the pit

*(PO) Fefers to the pit only, not the shaft 
LERA

One and Two World Trade Center Structural integrity inspection Accessible Columns

\section{LIST OFINSPECTED COLUMNS - 2 WTC (continued)}

Previously Inspected

\begin{tabular}{|c|c|c|c|}
\hline $\begin{array}{l}\text { Elevator } \\
\text { Shaft/Pit }\end{array}$ & $\begin{array}{l}\text { Column } \\
\text { Number }\end{array}$ & $\begin{array}{l}\text { Pits/Floors } \\
\text { Inspected }\end{array}$ & $\begin{array}{c}\text { Face of Column } \\
\text { Inspected }\end{array}$ \\
\hline 18 & 908 & $82 / 2-44$ & East \& South \\
\hline 28 & 907 & $82 / 2-44$ & North \\
\hline $38(P O)$ & 907 & 82 & East \& Soutt \\
\hline$\angle B(P O)$ & 906 & $\mathrm{~B} 2$ & North \\
\hline 58 & 906 & $\mathrm{~B} 2 / \mathrm{B} 1-44$ & East \& South \\
\hline 68 & 904 & $82 / 2-106$ & East \& South \\
\hline 78 & 903 & $82 / 2 \cdot 106$ & North \\
\hline $\mathrm{AB}(\mathrm{PO})$ & 903 & 82 & East \& South \\
\hline $9 B(P O)$ & 902 & 82 & North \\
\hline 108 & 908 & $82 / 2-44$ & East \& South \\
\hline 118 & 901 & $52 / 2 \cdot 44$ & North \&East \\
\hline 128 & 601 & $82: 2-44$ & North \&Wes? \\
\hline $13 B$ & 602 & $\mathrm{~B} 2 / 2-78$ & South \&West \\
\hline 148 & 602 & $82 / 2-78$ & North \\
\hline $15 B$ & 603 & $32 / 2-78$ & South \& West \\
\hline $16 B(P O)$ & 603 & $\mathrm{~B} 4$ & North \\
\hline $17 \mathrm{~B}(\mathrm{PO})$ & 604 & $B 4$ & South \& West \\
\hline 188 & 605 & $B 2 / 2-78$ & North \& West \\
\hline $19 B$ & 600 & $\mathrm{~B} 2 / 2-78$ & South \\
\hline $20 \mathrm{E}$ & 606 & $B 22.78$ & North \& West \\
\hline $21 B$ & 607 & $\mathrm{~B} 2 / 2-76$ & South \\
\hline $22 \mathrm{~B}$ & 607 & $B 2 / 2-78$ & North \& West \\
\hline 238 & 608 & $B 2 / 2-78$ & South \& West \\
\hline $24 B$ & 807 & $33 / 2-16$ & West \& South \\
\hline $25 B(S O)$ & 708 & $2 \cdot 16$ & East \& South \\
\hline $28 B(S O)$ & 707 & $1-16$ & East \& South \\
\hline $298(S 0)$ & 806 & $1-16$ & North \& West \\
\hline
\end{tabular}


LERA

5. LIST OF INSPECTED COLUMNS - 2 WTC (continued)

Previously Inspected (continued)

\begin{tabular}{|c|c|c|c|}
\hline $30 \mathrm{~B}$ & 806 & $B 1 / 2 \cdot 24$ & South \& West \\
\hline $31 \mathrm{~B}(\mathrm{SO})$ & 707 & $2-24$ & East \& South \\
\hline 348 & 706 & $B 1 / 2-23$ & North \& West \\
\hline 358 & 805 & $B 1 / 2-23$ & North \& Wes: \\
\hline 368 & 801 & $E 3 / 2 \cdot 32$ & North \& West \\
\hline $37 \mathrm{~B}(\mathrm{SO})$ & 701 & $2-32$ & North \& East \\
\hline $41 B(P O)$ & 802 & $\mathrm{B3}$ & South \& West \\
\hline $42 B$ & 802 & $83 / 2-40$ & North \& Wes: \\
\hline $43 \mathrm{~B}$ & 702 & $81 / 2-40$ & North \& West \\
\hline $47 \mathrm{~B}(\mathrm{PO})$ & 803 & 83 & South \& West \\
\hline $48 B$ & 905 & $83 / B 1 \cdot 40$ & North \& East \\
\hline $49 B(P O)$ & 704 & $\mathrm{B3}$ & South a West \\
\hline $50 B$ & 704 & $86 / 2-108$ & East \& South \\
\hline $50 B$ & 803 & $B 6 / 2-108$ & North \\
\hline 510 & 807 & $43 / 44 \cdot 54$ & South \& West \\
\hline $52 \mathrm{~B}$ & 708 & $43 / 44-54$ & South \& West \\
\hline $55 B(\mathrm{PO})$ & 707 & 43 & North, East \& West \\
\hline $55 \mathrm{~B}(50)$ & 707 & $45-54$ & Easi \& South \\
\hline $56 \mathrm{~B}(\mathrm{PO})$ & 806 & 43 & North, East \& Wes! \\
\hline $563(S O)$ & 806 & $45-54$ & North \& West \\
\hline $57 \mathrm{~B}$ & 806 & $43 / 44-61$ & South \& West \\
\hline $58 \mathrm{~B}$ & 707 & $43 / 44-61$ & Easi \& South \\
\hline 618 & 706 & $43 / 44-61$ & North \& West \\
\hline $62 \mathrm{~B}$ & 805 & $43 / 44-61$ & North \& West \\
\hline $638(\mathrm{PO})$ & 801 & 43 & North. East \& West \\
\hline $63 \mathrm{~B}(5 \mathrm{SO})$ & 801 & $44-67$ & North \& West \\
\hline 64B\{PO & 701 & 43 & North. Easi \& West \\
\hline $64 \mathrm{~B}(\mathrm{SO})$ & 701 & $44-67$ & North \& West \\
\hline
\end{tabular}

P1153902

Page 14

30 May 


\section{LERA}

One and Two World Trade Center Structural Integrity Inspection Accessible Columns

\section{LIST OF INSPECTED COLUMNS - 2 WTC (continued)}

Previously Inspected (continued)

\begin{tabular}{|c|c|c|c|}
\hline $\begin{array}{l}\text { Elevator } \\
\text { Shaft/Pit" }\end{array}$ & $\begin{array}{l}\text { Column } \\
\text { Number }\end{array}$ & $\begin{array}{l}\text { Pit/Floors } \\
\text { Inspected }\end{array}$ & $\begin{array}{c}\text { Face of Column } \\
\text { Inspected }\end{array}$ \\
\hline $67 \mathrm{~B}(\mathrm{PO})$ & 702 & 42 & East, South \& West \\
\hline $67 \mathrm{~B}(\mathrm{SO})$ & 702 & $44-67$ & East \& South \\
\hline $688(P O)$ & 802 & 43 & East, South \& West \\
\hline $68 \mathrm{~B}(\mathrm{SO})$ & 802 & $44-67$ & South \& West \\
\hline $69 \mathrm{~B}$ & 802 & $43 / 44-74$ & North \& West \\
\hline $70 B$ & 702 & $43 / 44-74$ & North \& West \\
\hline $73 B(P O)$ & 801 & 43 & East, South 3 West \\
\hline $74 \mathrm{~B}$ & 701 & 43 & Eas:, South \& West \\
\hline $768(P O)$ & 702 & 77 & East, South \& West \\
\hline $77 \mathrm{~B}(\mathrm{PO})$ & 802 & 77 & Eas?. South \& West \\
\hline $78 \mathrm{~B}(\mathrm{PO})$ & 707 & 76 & North, East \& West \\
\hline $78 \mathrm{~B}(\mathrm{SO})$ & 707 & $78-86$ & North \& East \\
\hline $79 B(P O)$ & 806 & 76 & Nonth. East \& West \\
\hline $79 \mathrm{~B}(\mathrm{SO})$ & 806 & $78 \cdot 86$ & North \& East \\
\hline $82 S(P O)$ & 801 & 77 & North, East \& West \\
\hline $83 B(P O)$ & 701 & 77 & Nortn. East \& West \\
\hline $88 \mathrm{~B}$ & 802 & $77 / 78-100$ & East. South \& West \\
\hline 898 & 702 & $77 / 78-100$ & East. South \& West \\
\hline 908 & 703 & $77 / 78-100$ & East \& South \\
\hline 918 & 803 & $77 / 78 \cdot 100$ & West \& South \\
\hline $95 \mathrm{~B}(\mathrm{PO})$ & 706 & 77 & West \& Narth \\
\hline 968 & 707 & $77778-106$ & East, South \& West \\
\hline $97 \mathrm{~B}$ & 806 & $77 / 78-106$ & East, South \& West \\
\hline 998 & $703 / 803$ & $105 / 106-110$ & South \\
\hline
\end{tabular}


Historical Review of World Trade Center Damping Units (WTCI-230-L)

Historical Review of World Trade Center Damper

Ming-Liblat

\begin{tabular}{|c|c|c|}
\hline Date & Fvent & $\begin{array}{l}\text { Stifiness, } \\
\text { kip'0.02".75 "F }\end{array}$ \\
\hline 9556 & Spccificalion detines stiffness and Waman!y & $6<F<20$ \\
\hline $\begin{array}{l}3 / 1277010 \\
413772\end{array}$ & 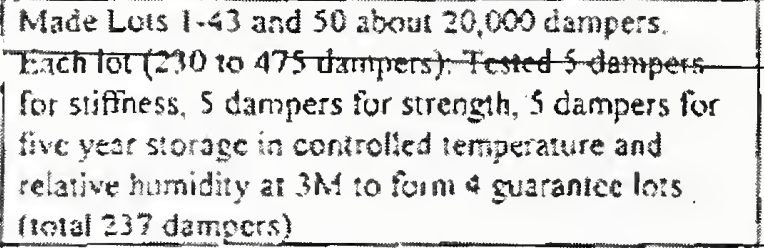 & $\begin{array}{l}\text { Avs }=14.368 \\
\text { Lowestofs } \\
\text { dampers }=10.178 \\
\text { lighest of } 5 \\
\text { dampers }=17.157\end{array}$ \\
\hline $\begin{array}{l}9 / 24 / 7160 \\
10 / 20 / 76\end{array}$ & $\begin{array}{l}3 \text { M retained extra dampers from guarantee Lots } 1 \\
\text { (first } 12 \text { acceptance lots) and Lol } 4 \text { (last } 10 \\
\text { acceptance lots) for intemal resting besides the } 5 \\
\text { year test required by Port Authonty. Dampers were } \\
\text { in temperature and honidiay controlled room } \\
3 \mathrm{M} \text { yested } 8 \text { dampers every } 6 \text { months for } 5 \text { years }\end{array}$ & $\begin{array}{l}\text { dropped from } \\
13.92 \text { 10 } 9.987\end{array}$ \\
\hline 51795 & $\begin{array}{l}6 \text { fres set by arsonist in WTC Towers. } \\
31 \text { iested } 3 \text { dampers from } 12 \text { th floor or WTC } \\
\text { Tower A }\end{array}$ & \\
\hline $\begin{array}{l}\text { spring } 10 \text { end } \\
\text { of } 1976\end{array}$ & $\begin{array}{l}\text { Completed } 5 \text { year test for the four guarantec lots } \\
\text { Por authority accepted the tesuls. } \\
\text { Shiped } 162 \text { dampers } 10 \text { Por: Authonty } \\
21 \text { dampers held by } 3 \mathrm{M} \text { (3M paid) }\end{array}$ & 10.7 accepted \\
\hline $5 / 8 / 81$ & $\begin{array}{l}10 \text { year aging data on } 3 \mathrm{M} \text { retains. A repont was } \\
\text { generaged by Calcwell }\end{array}$ & 9.5 \\
\hline 76632 & $\begin{array}{l}\text { Roterson submitied Por Authority the report by } \\
\text { Caldwell on } 3 \mathrm{M} \text { in-house testing showing decrease } \\
\text { in stiffness } \\
\text { Caldwell suggested iest } 6 \text { dampers from each lower } \\
\text { and } 6 \text { dampers from storage }\end{array}$ & \\
\hline W10/33 & 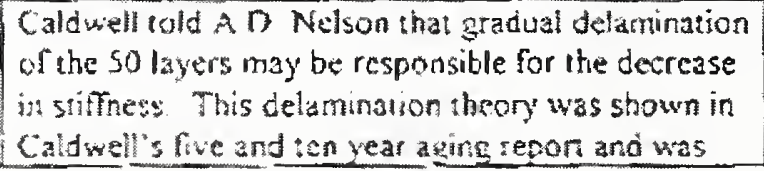 & \\
\hline
\end{tabular}




\begin{tabular}{|c|c|c|}
\hline & 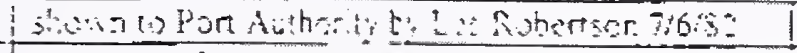 & \\
\hline 1231232 & 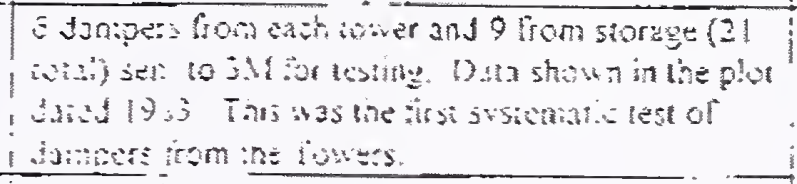 & \\
\hline $\begin{array}{l}\text { 4. } 20,7010 \\
\text { oisisiand } \\
119: 93\end{array}$ & 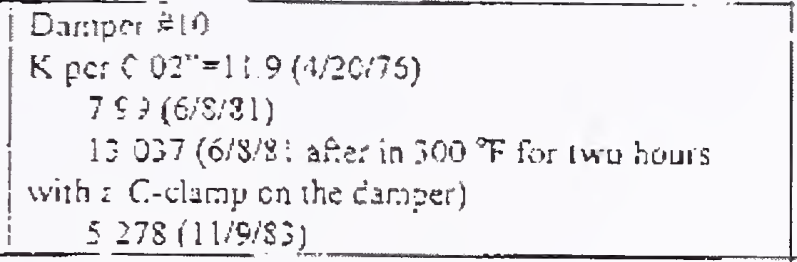 & \\
\hline $\begin{array}{l}\text { Sep: } 197 \mathrm{~s} \\
\text { and } \\
\text { Feb } 1587\end{array}$ & 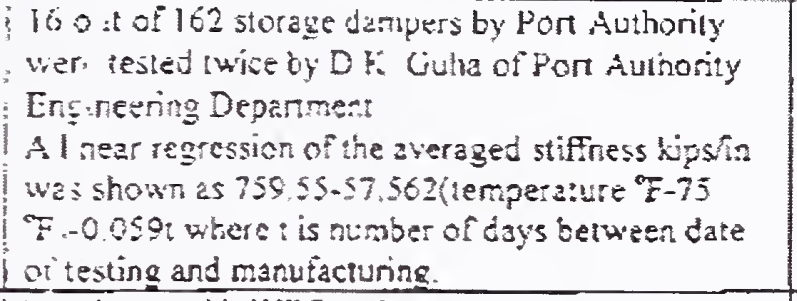 & $\begin{array}{l}12.2 \text { and } \\
11.0\end{array}$ \\
\hline $4 / 4 / 84$ & $\begin{array}{l}\text { Wind stom hit WTC. Maximum acceleration } 27 \\
\text { rig which is equivalent to } 27 " \text { sway. } \\
\text { Haximum acceleration recorded was } 37 \mathrm{mg} \text { on } \\
08 \text { th floor of Tower } A \text { on } 3 / 21 / 81 \text {. }\end{array}$ & \\
\hline $\begin{array}{l}\text { July and } \\
\text { October 19s4 }\end{array}$ & 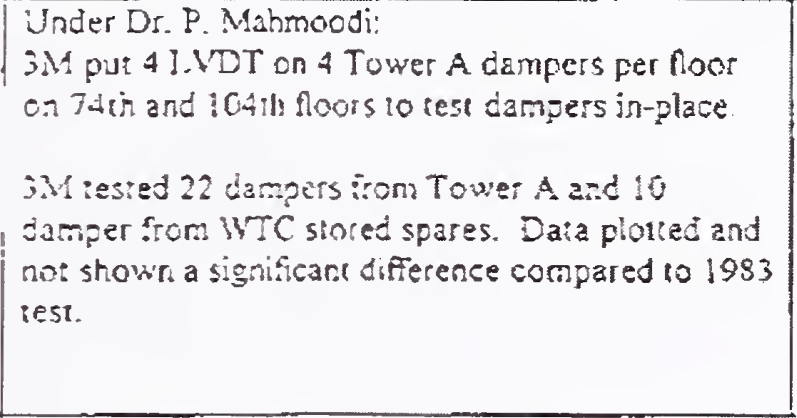 & $\begin{array}{l}8105 \text { for } 16 \\
\text { dampers from } \\
\text { Tower } A \text {. } \\
8698 \text { for } 10 \text { stcred } \\
\text { dampers. }\end{array}$ \\
\hline 7.17 .84 & Bind arestome:es and ecorder installed on BTC. & \\
\hline $10 / 1 / 1994$ & $\begin{array}{l}\text { Repon by Roberion, Fouler \& Ass on } \\
\text { "Investigarion of Agirg Effers: World Trade } \\
\text { Center Dampers" }\end{array}$ & \\
\hline $10 / 25: 93$ & 3n Iested 36 hIC zerpers in sterage & $\begin{array}{l}\text { 6.7 3versge } \\
\text { kange: } 7.6-10.1\end{array}$ \\
\hline $11 / 1 ! / 88$ & $3 M$ tested 4 dampers from WTC Towe: & 7810 \\
\hline $12 / 18 / 95$ & $\begin{array}{l}\text { 3M tested } 4 \text { dampers from WTC Tawer. Damper } \\
\text { displatement was measured by LVDT. }\end{array}$ & 7292 \\
\hline
\end{tabular}


This page intentionally left blank. 

